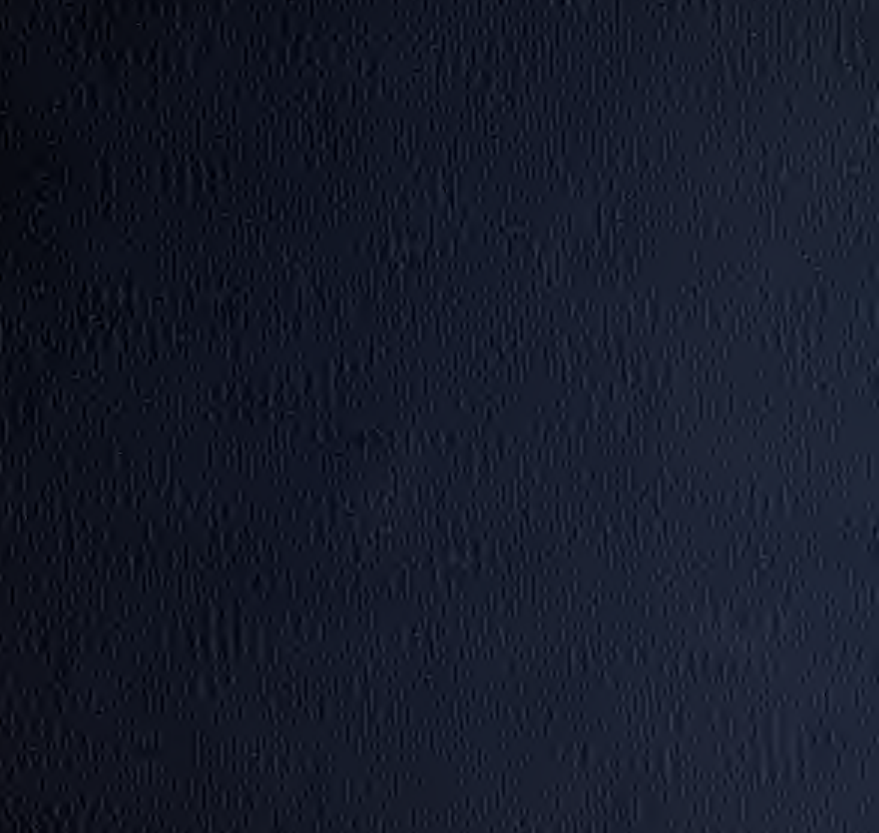

3 (4)

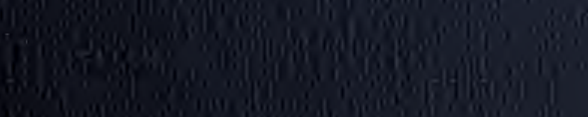

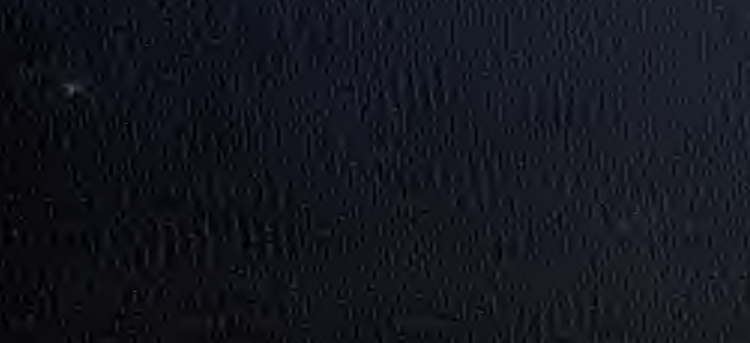




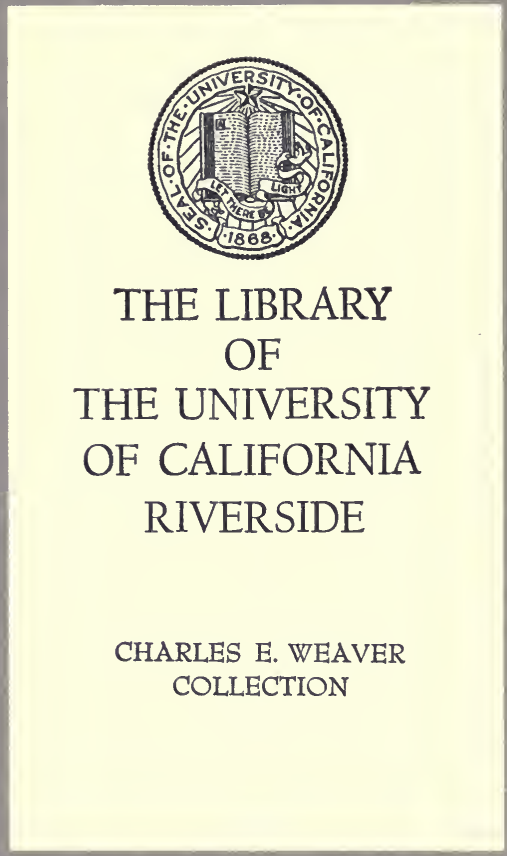




. 


\section{FOSSIL ECHINI OF THE WEST INDIES}

By Robert Tracy Jackson

STRATIGRAPHIC SIGNIFICANCE OF THE SPECIES OF WEST INDIAN FOSSIL ECHINI

By Thomas Wayland Vaughan

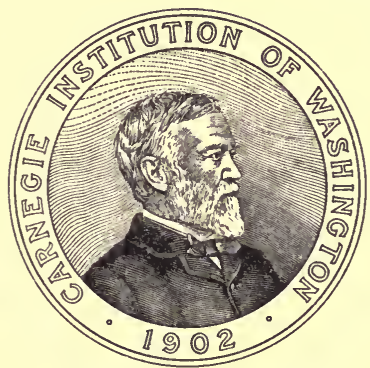

Published by the Carnegie Institution of Washington WASHINGTON, 1922 
phys. Sei.

QE 783

E2J8

1922

CARNEGIE INSTITUTION OF WASHINGTON

Publication No. 306

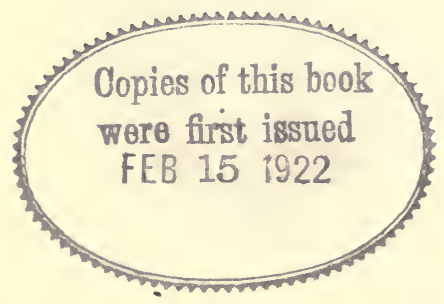




\section{CONTENTS.}

Fossil Echini of the West Indies, By Robert Tracy Jackson.

Geographical and Geological Distribution . . 4 Cuba . . . . . . . . . . . 4

Jamaica . . . . . . . . 5

Dominican Republic . . . . . . . 6

Porto Rico . . . . . . . . . . 6

Anguilla . . . . . . . . . . . 7

St. Bartholomew . . . . . . . . 8

Antigua . . . . . . . . . . . 8

Guadeloupe . . . . . . . . . . 9

Barbados ............ 10

Trinidad . . . . . . . . . . . 10

Geological Distribution .. . . . . . 10

Systematic Descriptions . . . . . . . . 14

Order Cidaroida . . . . . . . . . . . . 14

Family Cidaridæ . . . . . . . . . . . 14

Cidaris . . . . . . . . . . . . 14

C. anguillæ Cotteau . . . . . . 15

C. peloria, sp. nov. . . . . . . . . 16

C. foveata, sp. nov. . . . . . . 17

C. sp. a. ......... 18

C. sp. b. . . . . . . . . . 19

C. loveni Cotteau . . . . . . . . . 19

C. clevei Cotteau . . . . . . . . . 20

C. melitensis Wright ...... 21

C. tribuloides (Lamarck) . . . . . 23

Order Centrechinoida . . . . . . . . 23

Suborder Aulodonta . . . . . . . . . . . 23

Family Pedinidæ . . . . . . . . . . 23

Echinopedina . . . . . . . . 23

E. cubensis Cotteau . . . . . . . . 23

Family Hemicidaridæ . . . . . . . . . 24

Codiopsis . . . . . . . . . . . . 24

C. arnaudi Cotteau . . . . . . . . 24

Suborder Stirodonta . . . . . . . . . . 24

Family Saleniidæ . . . . . . . . 24

Salenia . . . . . . . . . 24

S. scutigera (Miinster) . . . . . . 24

Family Phymosomatidæ . . . . . . . . 25

Phymosoma .. . . . . . . 25

P. cubense (Egozcue) . . . . . . 25

Suborder Camerodonta . . . . . . . 25

Family Echinometridæ . . . . . . . 25

Echinometra . . . . . . . . 25

E. prisca Cotteau . . . . . . . . 25

Order Exocycloida . . . . . . . . . . . 27

Suborder Holectypina . . . . . . . . . . 27

Conulus . . . . . . . . . . . 27

C. antillensis (Cotteau) . . . . . 27

Lanieria . . . . . . . . . 28

L. lanieri (Cotteau) . . . . . . . 28

Discoidea . . . . . . . . . 29

D. decorata Desor . . . . . . 29

Suborder Clypeastrina . . . . . . . . 29

Family Fibulariidæ . . . . . . . . . . 29

Sismondia . . . . . . . . . . 29

S. antillarum Cotteau . . . . . . 30

S. anguillæ Cotteau . . . . . . 30
Systematic Descriptions-Continued

Suborder Clypeastrina-Continued

Family Clypeastridæ . . . . . . . 31

Anomalanthus ......... 31

A. gregoryi Lambert . . . . . . 31

Clypeaster . . . . . . . . . . 32

C. rosaceus (Linné) . . . . . . . . 33

C. concavus Cotteau . . . . . . . 34

C. caudatus, sp. nov. . . . . . . 36

C. dalli (Twitchell) . . . . . . 37

C. cubensis Cotteau . . . . . . . . 37

C. parræ Desmoulins . . . . . . . 38

C. lanceolatus Cotteau . . . . . . 38

C. antillarum Cotteau . . . . . . 39

C. planipetalus Cotteau . . . . . . 40

C. cryptopetalus, sp. nov. . . . . . 40

C. cotteaui Egozcue . . . . . . . . 41

C. batheri Lambert . . . . . . . . . . 42

C. parvus Michelin . . . . . . . . 42

C. duchassaingi Michelin . . . . . 43

C. ambigenus (Lamarck) . . . . . 43

C. placentoides, sp. nov. . . . . . . 43

C. meridanensis Michelin . . . . 44

C. oxybaphon, sp. nov. . . . . . . 44

C. platygaster, sp. nov. . . . . . . 45

Family Laganidæ . . . . . . . . . 46

Laganum . . . . . . . . . . . 46

L. elongatum Egozcue . . . . . . . 47

Peronella . . . . . . . . . 47

P. mirabilis, sp. nov. . . . . . . . 47

Family Scutellidæ . . . . . . . . 48

Echinarachnius .. . . . . . . 48

E. sebastiani, sp. nov. . . . . . . . 48

Encope . . . . . . . . . . 50

E. ciæ de Cortázar . . . . . . . . 50

E. latus, sp. nov. . . . . . . 51

Mellita ........... 52

M. sp. . . . . . . . . . . 52

Suborder Spatangina . . . . . . . 52

Family Echinoneidæ .. . . . . . . 54

Echinoneus . . . . . . . . . 54

E. orbicularis Desor . . . . . . . 54

E. cyclostomus Leske . . . . . . . 54

Amblypygus . . . . . . . . . . . 55

A. americanus Desor . . . . . 55

Family Nucleolitidæ . . . . . . . 56

Parapygus . . . . . . . . . 56

P. antillarum (Cotteau) . . . . . 56

P. parallelus (Cotteau) . . . . . 57

Echinolampas .. . . . . . . 57

E. semiorbis Guppy . . . . . . . . 58

E. antillarum Cotteau . . . . . . 59

E. ovumserpentis Guppy . . . . . 60

E. clevei Cotteau . . . . . . . . . 63

E. lycopersicus Guppy .. . . . . 64

E. castroi Cotteau . . . . . . . 66 
Systematic Descriptions-Continued. Suborder Spatangina-Continued.

Family Nucleolitida-Continued. Echinolampas-Continued.

E. anguillæ Cotteau . . . . . . 66

Family Plesiospatangidx ...... 67

Asterostoma ... . . . . . 67

A. excentricum (Lamarck) . . . . 67

A. cubense Cotteau . . . . . . 67

Pseudasterostoma . . . . . . 68

P. jimenoi (Cotteau). . . . . . . 68

Family Echinocorythidæ. . . . . . . 69

Cardiaster ...... . . . . 69

C. cubensis, sp. nov. . . . . . . 69

Family Hemiasteridæ . . . . . . . 70

Agassizia .......... . 70

A. inflata, sp. nov. . . . . . 70

A. clevei, Cotteau . . . . . . 71

Prenaster . . . . . . . . . 72

P. loveni Cotteau . . . . . . . 72

Hemiaster . . . . . . . . . 73

H. cubensis (d'Orbigny) . . . . . . 73

H. antillensis Cotteau . . . . . . 73

H. dewalquei Cotteau . . . . . 73

H. berkeyi, sp. nov. . . . . . . 73

Paraster ........... 74

P. antillarum (Cotteau) . . . . 75

P. parkinsoni (Defrance) . . . 76

P. clevei (Cotteau) . . . . . . . 76

P. loveni (Cotteau) . . . . . . 77

P. subcylindricus (Cotteau) . . . 78

P. sp. a. . . . . . . . 79

P. sp. b. . . . . . . . . 79

Periaster .......... . 80

P. elongatus Cotteau ... . . 80
Systematic Descriptions-Continued.

Suborder Spatangina-Continued.

Family Hemiasteridæ-Continued.

Schizaster ......... 81

S. scillæ Agassiz . . . . . . . . . 81

Family Spatangidæ . . . . . . . 81

Brissopsis . . . . . . . . . 81

B. jimenoi Cotteau . . . . . . 81

B. atlantica Mortensen . . . . 81

B. antillarum Cotteau . . . . . 82

Plagiobrissus . . . . . . . . 83

P. loveni (Cotteau) . . . . . . 83

Macropneustes .......... 84

M. clevei (Cotteau) . . . . . . 84

M. antillarum (Cotteau) . . . . 85

Brissus ......... . . 86

B. brissus (Leske) . . . . . . . 87

B. exiguus Cotteau . . . . . . . 87

Eupatagus . . . . . . . . . 88

E. grandifiorus (Cotteau) . . . . 89

E. 8p. a. . . . . . . . . . 90

E. clevei (Cotteau) . . . . . . . 90

E. antillarum (Cotteau) . . . . . . 91

E. depressus, sp. nov. . . . . . . . 93

E. abruptus (Gregory) . . . . . . 94

E. cubensis (Cotteau) . . . . . . . 94

E. elegans, sp. nov. . . . . . . . 94

E. vaughani, sp. nov. . . . . . . 96

E. sp. b. . . . . . . . . . 97

Breynia . . . . . . . . . . 97

B. cubensis Cotteau . . . . . . 97

Bibliography . . . . . . . . . . . 99

Description of Plates . . . . . . . 100

\section{Stratigraphic Significance of the Species of West Indian Fossil Echini, By Thomas Wayland Vaughan}

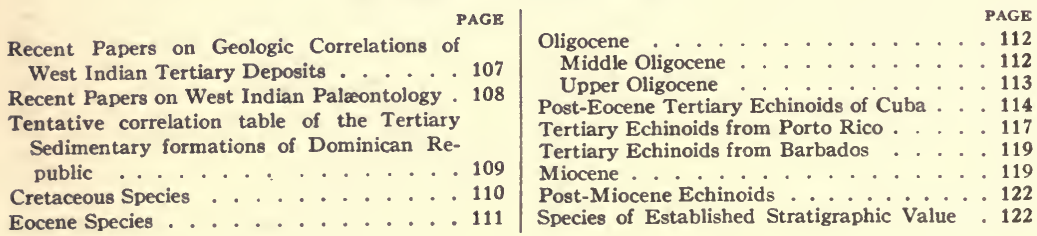




\title{
FOSSIL ECHINI OF THE WEST INDIES.
}

\author{
By Robert Tracy Jackson.
}

With eighteen plates and six text-figures. 



\section{FOSSIL ECHINI OF THE WEST INDIES.}

\section{INTRODUCTION.}

At the request of Dr. T. Wayland Vaughn, I undertook to make a study of and prepare a report on the fossil Echini of the West Indies, to form a part of his geological and palæontological survey of that region.

I would express my deepest obligations to Dr. Hubert Lyman Clark, Curator of Echinoderms in the Museum of Comparative Zoölogy, Cambridge, whose great knowledge of Recent Echini and whose most generous help were placed constantly at my disposal.

The species described or otherwise considered include Echini from the Greater Antilles, namely, Cuba, Jamaica, the Dominican Republic in Haiti, and Porto Rico. Also Echini are described or listed from a number of islands of the Lesser Antilles, including Anguilla, St. Bartholomew, Antigua, Guadeloupe, and Barbados, also from the island of Trinidad off the coast of South America. Besides the species of which I have had material, the attempt is made to record all species previously published as occurring fossil in the West Indies. I have recognized 89 species; of these, I have had specimens of 57 , of which 16 are described as new; 32 of the recognized species were not seen, but in order to give completeness they are included, with a reference and locality but without description; they are largely from Cotteau's Spanish report on the fossil Echini of Cuba. ${ }^{1}$

The material on which this report is based is from several sources, but principally from the Cleve collection of Echini, now the property of the U.S. National Museum, from the islands of St. Bartholomew and Anguilla. This collection is very important on account of its extent and also as being the basis of Gustave Honoré Cotteau's beautiful memoir, "Description des Échinides Tertiaires des Îles St. Barthélemy et Anguilla," published in 1875. Of the 33 species described in that memoir, the Cleve collection is represented in every species, and in 23 of the species the Cleve collection alone is recorded. What other material Cotteau had, as stated in his memoir, was from the museums of Stockholm and Upsala, or from his own collection.

The late R. J. Lechmere Guppy, of Trinidad, wrote of this collection (1882, Scientific Assoc. Trinidad Proc., part 12, pp. 193-199) that in 1868-69 Professor P. T. Cleve, of the University of Upsala, traveled in the West Indies and investigated the geology and mineralogy, an account of which he published (1871, Kongl. Sven. Vet. Akad. Handl., vol. 9, No. 12). Professor Cleve made a collection of fossils, among

\footnotetext{
1 For species not included, as they are not recognizable, see lists by A. Agassiz, Duchassaing, Michelin, Desor, and Gregory, referred to in foot-notes, pages 6, 9, and 10.
} 
which was a fine series of Echinoderms from the islands of St. Bartholnmew and Anguilla. These were studied by M. Cotteau, who distinguished 33 species, all carefully described and delineated in a paper published in 1875. By the kindness of Professor Cleve, the collection came into the hands of Mr. Guppy, who published brief notes on it. Later, it was purchased with some other material, in 1893 , by the United States National Museum, where it now is.

Dr. William H. Dall, through whose intervention this collection came to the museum, writes that the specimens were glued to wooden tablets. The names, sometimes written and sometimes printed from Guppy's publications, were pasted on the tablets. There was no indication of their locality other than the island, as "Trinidad," and none as to whom they had been given for description. Dr. Dall personally copied the labels when they were removed from the tablets. Some of the material in the Cleve collection is beautifully preserved, while parts of it are in poor condition.

I regret to say that Cotteau's figures were very freely and often, it seemed, unwarrantably restored in making the drawings from the specimens, so that structural details figured may be quite wanting in the specimen. This statement can be verified by comparing the photographic figures with Cotteau's published figures of the very same specimens. The measurements of specimens often differed from those given in Cotteau's paper. I would say that my measurements were made with a steel caliper rule from the specimens in Washington, with Cotteau's memoir open before me, so that any discrepancies in measurements are a difference of observation.

The Cleve collection is the most extensive collection of fossil Echini from the area that I know of. It was studied during two visits to Washington when notes were taken and specimens were selected for photographing, which was done under the supervision of Dr. C. Wythe Cooke of the U. S. Geological Survey, to whom I would express the warmest thanks for the pains he took in this work.

Quite a large amount of echinoid material was collected by Dr. T. Wayland Vaughan from the islands of Antigua, Anguilla, and St. Bartholomew, and a few Echini from the Dominican Republic. From the American Museum of Natural History, besides several isolated specimens, was borrowed a fine lot of material from Porto Rico, including some very interesting species. This Porto Rican material was collected by Dr. C. A. Reeds, with the aid of a field assistant, Mr. Prentice B. Hill, while on an expedition under the joint auspices of the New York Academy of Sciences, the Porto Rican Government, and the American Museum of Natural History.

The Philadelphia Academy of Natural Sciences kindly loaned a few specimens from Antigua, Cuba, and Trinidad. A few interesting species from Cuba and Jamaica were studied in the Museum of Comparative 
Zoölogy, where also library and other facilities were kindly given me by the director, Mr. Samuel Henshaw.

Of private collections, Mr. Charles T. Ramsden, of Guantanamo, Cuba, loaned some very choice material from Cuba, including Clypeaster cotteaui, Echinolampas anguilla, and the species Clypeaster placentoides and Cardiaster cubensis, which are here described as new. Dr. Carlotta J. Maury, of Hastings-on-Hudson, New York, collected in the Dominican Republic, in 1917, three choice Echini, Clypeaster dalli and two specimens of Clypeaster caudatus, the latter here described as a new species. These, with other material, she has kindly presented to the U. S. National Museum. Mr. G. J. Mitchell loaned some Echini that he collected in Porto Rico, namely, Clypeaster rosaceus and Hemiaster berkeyi, the latter described as a new species.

To these several institutions and individuals I would express warm thanks for the loan of material and facilities accorded me. To Dr. T. Wayland Vaughan I would express very special obligations for numerous letters giving facts in regard to the material and the localities and for his great patience under a protracted research.

Photographs illustrating specimens in the Guppy collection were taken in Washington as above stated. Photographs of other specimens were by Mr. F. A. Saunderson or Mr. E. N. Fischer, both of Boston. Mr. Saunderson took the photographs illustrating plates 4,6 to 8,17 , and 18, also 17 photographs scattered through other plates. Mr. Fischer took the photographs illustrating plate 2 , figures 2 to 5 , plate 3 , and plate 12, figure 1 . The few text-figures were drawn by Mr. J. Henry Blake.

Besides the species described, there were in the various collections studied many Echini too imperfect for identification, but which indicate that in future the West Indian fossil fauna of this group may be much enriched by new material.

In regard to new material turning up, it is of interest that a new species of Eupatagus has been received (too late to describe here) from the foraminiferal limestone (doubtless Oligocene) on the summit of Bissex Hill, Barbados. Collected by the Honorable A. P. Haynes, it was kindly given to the U. S. National Museum by Sir John B. Harrison, formerly stationed at Barbados, who has done much to further science in the West Indies.

Of the previously published records of fossil Echini occurring in the West Indies, Guppy in 1866 published notes and a few new species. Cotteau in 1875 described many new species from the islands of St. Bartholomew and Anguilla, and in 1881 and 1897 published large papers on the fossil Echini of Cuba. Lambert in 1915 published on a collection of Echini from the islands of Anguilla and Antigua. This material, which is in the British Museum, was collected by J. W. Gregory, with the addition, as Lambert says, of some Miocene Echini from Anguilla included by Bather. Two new species are described, 
Anomalanthus gregoryi, a very interesting addition to the fauna, and Clypeaster batheri. Dr. F. A. Bather, who kindly sent me the reference to Lambert's paper, writes that Gregory collected in Anguilla and Antigua in 1899. Besides the above authors, Michelin, Desor, Egozcue, de Cortázar, J. W. Gregory, A. Agassiz, and Hill published descriptions of species or lists of species from the various islands of the West Indies. As noted (p. 98), Kew in a paper on fossil Echini of Northeastern Mexico, records several of Cotteau's West Indian species as occurring in Mexíco. Excepting two species, one an Agassizia and one a Macropneustes, I think the identifications are mistaken.

\section{GEOGRAPHICAL AND GEOLOGICAL DISTRIBUTION OF WEST INDIAN FOSSIL ECHINI.}

In order to bring out the distribution of the fossil Echini in the West Indies, the species are grouped here in tabular form, taking up the several islands geographically, and following with a table showing the geological distribution. Where I have not seen specimens from the localities as listed, or, indeed, in many cases, have not had specimens of the species at all, the names are marked with references to foot-notes where the authority for the references is given.

An interesting and striking fact has been pointed out by students of other groups of West Indian fossils, that the species in many cases bear a stronger resemblance to Australian and Indo-Pacific types in the Recent fauna than they do to Western Atlantic types. This resemblance in the Echini is noticeable in the cases of Cidaris peloria, C. foveata, and Cidaris sp. b. (p. 19); the same is true of Clypeaster oxybaphon. The genera Anomalanthus, Laganum, Peronella, Brissus, Eupatagus, and Breynia, while occurring fossil in the West Indies, in the living fauna are essentially Indo-Pacific types. The West Indian fossil species of Echinolampas are more like the Recent Indo-Pacific than like the living West Indian species.

At the close of this paper, Dr. T. Wayland Vaughan gives a critical study of the stratigraphical relations of the West Indian fossil Echini. His extensive knowledge of the region enables him to treat this aspect of the subject, whereas it would be quite beyond my technical experience.

\section{CUBA.}

Cuba being the largest of the West Indian islands, and collections from there having been the most extensively published, has yielded many species of fossil Echini. The species as listed are largely taken from Cotteau's monograph on the fossil Echini of Cuba, in which memoir all the species are well figured. 
List of Fossil Echini occurring in the Island of Cuba.

\begin{tabular}{|c|c|c|c|c|c|}
\hline Species. & $\begin{array}{l}\text { Creta- } \\
\text { ceous. }\end{array}$ & Eocene. & $\begin{array}{l}\text { Oligo- } \\
\text { cene. }\end{array}$ & Miocene. & $\begin{array}{c}\text { Post- } \\
\text { Miocene. }\end{array}$ \\
\hline Cidaris tribuloides (Lamarck) . . . . . . . . & & & & $x$ & \\
\hline Echinopedina cubensis Cotteau....... & & ? & & $?$ & \\
\hline 1 Codiopsis arnaudi Cotteau. . ......... & $\times$ & & & & \\
\hline${ }^{1}$ Salenia scutigera (Münster) .......... & $x$ & & & & \\
\hline${ }^{1}$ Phymosoma cubense (Egozcue)...... & $x$ & & & & \\
\hline Echinometra prisca Cotteau.......... & & & ? & $?$ & \\
\hline${ }^{1}$ Conulus antillensis (Cotteau) . . . . . . & $x$ & & & & \\
\hline Lanieria lanieri (Cotteau) ............ & $x$ & & & & \\
\hline${ }^{1}$ Discoidea decorata Desor............ & $x$ & & & & \\
\hline${ }^{1}$ Clypeaster rosaceus (Linné) .......... & & & & & $x$ \\
\hline Clypeaster concavus Cotteau. . . . . . . . & $\ldots .$. & ..... & $\mathrm{x}$ & & \\
\hline 1 Clypeaster cubensis Cotteau........ & $\cdots \cdots$ & & & ? & \\
\hline${ }^{1}$ Clypeaster parræ Desmoulins......... & ...... & . & $x$ & & \\
\hline Clypeaster lanceolatus Cotteau . . . . . . & $\ldots$. & .. & $\times$ & ? & \\
\hline Clypeaster antillarum Cotteau...... & .... & .. & $x$ & & \\
\hline 1 Clypeaster planipetalus Cotteau..... & $\cdots$ & & $x$ & & \\
\hline Clypeaster cotteaui Egozcue . . . . . . . & & ..... & $x$ & & \\
\hline ' Clypeaster parvus Michelin.......... & .... & ..... & $?$ & & \\
\hline Clypeaster placentoides, sp. nov...... & $\ldots \ldots$ & $\ldots \ldots \ldots$ & $x$ & & \\
\hline Clypeaster platygaster, sp. nov....... & ....... & 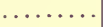 & $x$ & & \\
\hline${ }^{1}$ Laganum elongatum Egozcue....... & .... & . & $?$ & & \\
\hline${ }^{1}$ Encope ciæ de Cortázar........... & ..... & & 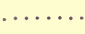 & ? & \\
\hline${ }^{1}$ Echinoneus orbicularis Desor... & $\cdots$ & & & & $x$ \\
\hline Echinoneus cyclostomus Leske.... & & & ? & ? & \\
\hline 1 Parapygus antillarum (Cotteau)..... & . & $x$ & & & \\
\hline 1 Parapygus parallelus (Cetteau) ....... & $\ldots \ldots$ & $?$ & & & \\
\hline Echinolampas semiorbis Guppy....... & $\ldots \ldots$ & & $x$ & & \\
\hline Echinolampas ovumserpentis Guppy.. & ...... & $x$ & & & \\
\hline 1 Echinolampas clevei Cotteau......... & ...... & $x$ & & & \\
\hline Echinolampas lycopersicus Guppy.... & & & $x$ & & \\
\hline${ }^{1}$ Echinolampas castroi Cotteau........ & $\ldots \ldots$ & $x$ & & & \\
\hline Echinolampas anguillæ Cotteau ....... & & & $x$ & & \\
\hline 1 ? Asterostoma excentricum (Lamarck) & & $?$ & & & \\
\hline${ }^{1}$ Asterostoma cubense Cotteau......... & & $x$ & & & \\
\hline${ }^{1}$ Pseudasterostoma jimenoi Cotteau... & $\ldots \ldots$ & $x$ & & & \\
\hline Cardiaster cubensis, sp. nov. . . . . . . & $x$ & & & & $x$ \\
\hline $\begin{array}{l}1 \text { Hemiaster cubensis (d'Orbigny)....... } \\
1 \text { Hemiaster antillensis Cotteau....... }\end{array}$ & ... & ? & & & $x$ \\
\hline 1 Hemiaster dewalquei Cotteau......... & & $?$ & & & \\
\hline 1 Paraster parkinsoni (Defrance) ...... & & ...... & $x$ & & \\
\hline 1 Schizaster scillæ Agassiz........... & & ... & $?$ & $?$ & \\
\hline${ }^{1}$ Brissopsis jimenoi Cotteau......... & & & & $x$ & \\
\hline${ }^{1}$ Macropneustes clevei (Cotteau)..... & & & $x$ & & \\
\hline 1 Macropneustes antillarum (Cotteau). & ... & $x$ & & & \\
\hline${ }^{1}$ Brissus brissus (Leske)............ & & & & & $?$ \\
\hline${ }^{1}$ Eupatagus cubensis (Cotteau) ....... & & $x$ & & & \\
\hline 1 Breynia cubensis Cotteau...... & & $?$ & & & \\
\hline
\end{tabular}

1 Cotteau, 1897, Bol. Com. Mapa Geol. España, vol. 22.

JAMAICA.

List of Fossil Echini occurring in the Island of Jamaica.

Cidaris foveata, sp. nov.

Clypeaster cotteaui Egozcue.

Amblypygus americanus Desor.
Echinolampas ovumserpentis Guppy.

Paraster sp. a.

Eupatagus sp. a.

This short list of Jamaican Echini includes specimens which are in the Museum of Comparative Zoölogy, and are the only ones I have 
seen from the Island. ${ }^{1}$ They are all probably from strata of Eocene age (Cambridge formation?), excepting Clypeaster cotteaui, which is apparently Oligocene.

R. T. Hill, in his Geology and Physical Geography of Jamaica (1899, Bull. Mus. Comp. Zoöl., vol. 34), mentions having a few Echini from Jamaica. Under the Blue Mountain series, Cretaceous ( $p$. 118), he gives Salenia, but without specific name. Under the Cambridge formation, Eocene, with lists of other groups of fossils, he notes (p. 128) the occurrence of the following Echini: Scutellina from Cambridge and Catadupa; Acrocidaris from Catadupa; Rapinot pneustio [apparently a clerical error for Macropneustes] from Great River; Diplopodia and Echinolampas from Great River; and Echinanthus [probably Clypeaster] from Retrieve. Mr. Hill states in a note that these several echinoids are in his own collection or in the collection of the Institute of Jamaica. He further remarks that Macropneustes and Pygorhymchus have also been collected from the Cambridge formation, Eocene, at Mountain Spring, St. Elizabeth, and Maroontown.

\section{DOMINICAN REPUBLIC.}

List of Fossil Echini occurring in the Dominican Republic, Island of Haiti.

\begin{tabular}{|c|c|c|c|}
\hline Species. & Oligocene. & Miocene. & Pliocene. \\
\hline 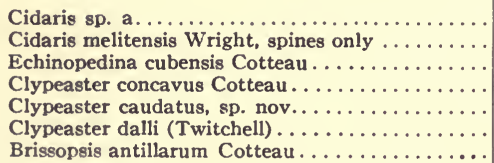 & 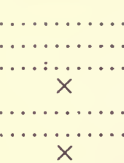 & $\begin{array}{l}\times \\
\times \\
\times \\
\times\end{array}$ & $?$ \\
\hline
\end{tabular}

This list of fossil Echini from the Dominican Republic includes specimens recently collected by Dr. Carlotta J. Maury or by Dr. Vaughan and Dr. Cooke. Miss Maury obtained the Echini while collecting fossil molluscs in the Dominican Republic, a description of which she published in 1917 in the Bulletin of American Paleontology, Nos. 29 and 30.

\section{PORTO RICO.}

The Echini here listed are all from the collections made on the Scientific Survey of Porto Rico by the New York Academy of Sciences, the Porto Rican Government and the American Museum of Natural History coöperating. The specimens were mainly collected by Dr. Chester A. Reeds, with Mr. Prentice B. Hill as an assistant, in the

${ }^{1}$ Desor, 1858, Synopsis des Échinides, p. 299, describes Pygorhynchus jamaicensis Desor as occurring fossil in Jamaica. It apparently has never been figured. 
List of Fossil Echini occurring in the Island of Porto Rico.

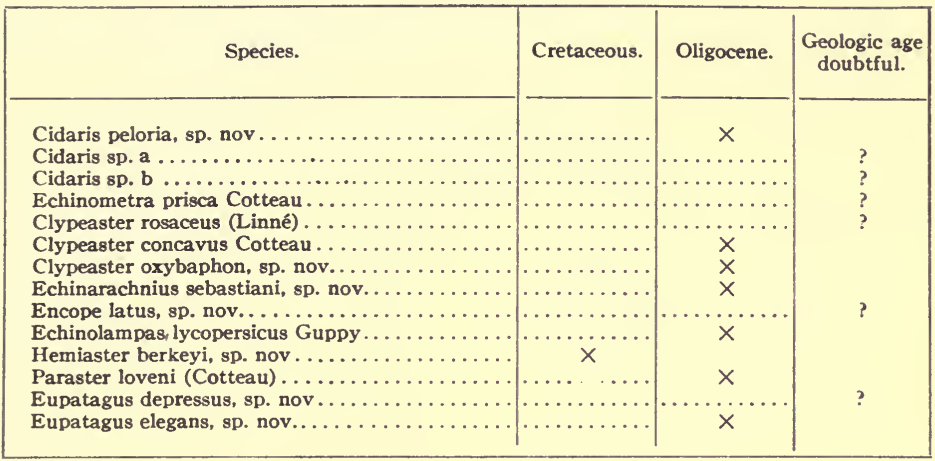

months of June and July 1915. Some of the results of the work of this Scientific Survey of Porto Rico have already appeared in the publications of the New York Academy of Sciences. In his Geological Introduction (1919, New York Academy of Sciences, vol. I, part 1), Professor C. P. Berkey gives an account of the geological features of the island and a discussion of the age of the rock formations. Miss Carlotta J. Maury (1920, New York Acad. Sciences, vol. III, part 1) describes the Tertiary molluscs of Porto Rico and gives a table of the correlation of Tertiary formations of Porto Rico with other West Indian islands.

\section{ANGUILLA.}

List of Fossil Echini occurring in the Island of Anguilla.

Cidaris anguillæ Cotteau.

Cidaris clevei Cotteau.

Cidaris melitensis Wright.

Echinometra prisca Cotteau.

Sismondia anguillæ Cotteau.

1 Clypeaster rosaceus (Linné).

Clypeaster concavus Cotteau.

Clypeaster antillarum Cotteau.

Echinoneus cyclostomus Leske.

Echinolampas semiorbis Guppy.
Echinolampas lycopersicus Guppy.

Echinolampas anguillæ Cotteau.

Agassizia clevei Cotteau.

${ }^{2}$ Paraster parkinsoni (Defrance).

Paraster clevei (Cotteau).

Paraster loveni (Cotteau).

1 Brissopsis atlantica Mortensen.

Brissopsis antillarum Cotteau.

Macropneustes clevei (Cotteau).

Brissus exiguus Cotteau.

These species of Echini from Anguilla were for the most part included in the Guppy ex Cleve collection, which was made by Professor P. T. Cleve in 1868-69, and on which was based Cotteau's memoir on the fossil Echini of the islands of St. Bartholomew and Anguilla. Additional material has since been collected on the island by $\mathrm{J}$. W. Gregory in 1899 and by T. W. Vaughan in 1914. Lambert reports 
two additional species collected by Gregory, and A. Agassiz records Paraster parkinsoni as noted. Except Clypeaster rosaceus and Brissopsis atlantica, all of the species from Anguilla are from the Anguillan upper Oligocene.

\section{ST. BARTHOLOMEW.}

List of Fossil Echini occurring in the Island of St. Bartholomew.

Cidaris loveni Cotteau.

Sismondia antillarum Cotteau.

Parapygus antillarum (Cotteau).

Echinolampas antillarum Cotteau.

Echinolampas ovumserpentis Guppy.

Echinolampas clevei Cotteau.

Asterostoma cubense Cotteau.

Agassizia inflata, sp. nov.

Prenaster loveni Cotteau.

\begin{abstract}
Paraster antillarum (Cotteau).
Paraster subcylindricus (Cotteau).

Periaster elongatus Cotteau.

Plagiobrissus loveni (Cotteau).

Macropneustes antillarum (Cotteau).

Eupatagus grandiflorus (Cotteau).

Eupatagus clevei (Cotteau).

Eupatagus antillarum (Cotteau).

Eupatagus sp. b.
\end{abstract}

Of the species of Echini listed from the island of St. Bartholomew, Agassizia inflata is described as new. The type of this species was included in Agassizia clevei by Cotteau, but it is considered distinct from that species as discussed in the text. A large Eupatagus collected by Dr. Vaughan in 1914 is considered distinct from other known species, but is too incomplete for description as a new species. Otherwise all the species here given from St. Bartholomew were included in the Guppy ex Cleve collection, which was made by Cleve in 1868-69 and on which was based Cotteau's memoir on the fossil Echini of the islands of St. Bartholomew and Anguilla. ${ }^{1}$ Much additional material, however, was collected from the island by Dr. Vaughan in 1914. All of these species are from the upper Eocene St. Bartholomew limestone.

\section{ANTIGUA.}

List of Fossil Echini occurring in the Island of Antigua.

Sismondia anguillæ Cotteau.

2 Anomalanthus gregoryi Lambert.

Clypeaster concavus Cotteau.

2 Clypeaster lanceolatus Cotteau.

Clypeaster antillarum Cotteau.

Clypeaster planipetalus Cotteau.

Clypeaster cryptopetalus, sp. nov.

2 Clypeaster cotteaui Egozcue.
2 Clypeaster batheri Lambert.

2 Clypeaster parvus Michelin.

Clypeaster oxybaphon, sp. nov.

2 Echinolampas lycopersicus Guppy.

2 Echinolampas anguillæ Cotteau.

Paraster clevei (Cotteau).

Eupatagus vaughani, sp. nov.

Dr. J. W. Gregory reported (1895, Quart. Jour. Geol. Soc. London, vol. 51) specimens of Clypeaster concavus and $C$. antillarum from Antigua. The material was in a collection sent to London by J. Vincent Forrest, Esq. Gregory remarks that no fossil echinoids had previously been recorded from the island. Dr. Bather informs me

\footnotetext{
1 For one species, Sismondia alta, not included, as it is not considered recognizable, see list by A. Agassiz referred to in foot-note, p. 9.

${ }^{2}$ Lambert, 1915, Mém. Soc. d'Agric. de l'Aube (Troyes), vol. 79, pp. 17-34.
} 
that this material is not in the British Museum. Later, in 1899, Doctor Gregory visited Antigua (as well as Anguilla) and collected Echini which are in the British Museum.

Dr. A. P. Brown collected a number of fossil Echini in Antigua, in 1913, and his specimens are in the collections of the Philadelphia Academy of Natural Sciences; his notes on the geology are published in the Proceedings of that institution. Doctor Vaughan, in 1914, visited Antigua and collected quite a large amount of material. Lambert in 1915 published the results of Gergory's collecting, with some additional material (from Anguilla). The above list of Echini from Antigua is based on the Vaughan and Brown collections, which I have studied, and in addition on Lambert's publication.

All these species, except perhaps Anomalanthus gregoryi Lambert, are supposed to come from the Antigua formation, Middle Oligocene.

Anomalanthus gregoryi, having a different matrix from the other species, as recorded by Lambert, may have come from a different bed and horizon.

\section{GUADELOUPE.}

\section{List of Fossil Echini occurring in the Island of Guadeloupe.}

1 (?) Lanieria lanieri (Cotteau).

2 Clypeaster parræ Desmoulins.

${ }^{2}$ Clypeaster parvus Michelin.

${ }^{3}$ Clypeaster duchassaingi Michelin.
${ }^{3}$ Clypeaster ambigenus (Lamarck).

1 Clypeaster meridanensis Michelin.

1 Echinoneus cyclostomus Leske.

${ }^{1}$ Brissus brissus (Leske).

I have not seen any echinoid material from the island of Guadeloupe, and the species indicated are taken from A. Agassiz's list of West Indian Echini in the Blake report, from Cotteau's Spanish report, and from Michelin's Monograph of Clypeastroids, ${ }^{4}$ all as indicated in foot-notes.

The occurrence of Lanieria lanieri in Guadeloupe is probably a mistake, as the species is known otherwise only from the Cretaceous of Cuba. The other species listed are probably all late Tertiary, but A. Agassiz ${ }^{5}$ is the only authority cited who gave a definite horizon in recording the occurrence of the species. ${ }^{6}$

${ }^{1}$ A. Agassiz, 1883, Blake Echini. Mem. Mus. Comp. Zoöl. vol. 10, No. 1, pp. 88-93.

2 Cotteau, 1897, Spanish report, Bol. Com. Mapa Geol. España, vol. 22.

- Michelin, 1861, Monographie Clypéastres fossiles, Mém. Soc. Géol. de France, ser. 2, vol. 7.

- Desor, 1858, Synopsis des Échinides, p. 234, briefly describes Scutella michelini Desor, which, he says, occurs fossil in Guadeloupe; and on p. 288 he describes Rhynchopygus guadeloupensis Desor, which, he says, occurs in the Quaternary of Guadeloupe.

${ }_{5}$ Mr. A. Agassiz (1883, Blake Echini), in his tables of geographical and geological distribution of West Indian Echini, pp. 88-91, lists the following species which are apparently nomina nuda or synonyms: Sismondia alta Cott. Eocene, St. Barts; Clypeaster incurvatus Desm., Pliocene, Guadeloupe; Mellita ampla Holmes, Pliocene, Guadeloupe.

- Duchassaing (1855, Observations sur les formations modernes de l'île de la Guadeloupe, Bull. Soc. Géol. de France, ser. 2, vol. 12, pp. 753-757) gives a list of 13 species of Echini occurring in the white tuff at Guadeloupe. He gives no authority for the species and their identification is doubtful. The last two pages of his paper contain a list by Michelin entitled "Échinides vivants et fossiles des Antilles et du Golfe du Mexique." This list contains many nomina nuda or obvious mistakes of identification. 


\section{BARBADOS.}

Echinolampas anguille Cotteau ${ }^{1}$ and Eupatagus abruptus (Gregory) ${ }^{2}$ are the only recognizable fossil species of Echini recorded from the island of Barbados as far as discovered. ${ }^{3}$ (Another species, see p. 3.)

TRINIDAD.

List of Fossil Echini occurring in the Island of Trinidad.

\begin{tabular}{|c|c|c|}
\hline Species. & Eocene. & Miocene. \\
\hline 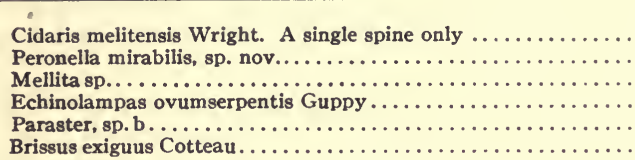 & 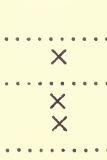 & $\begin{array}{l}x \\
\times\end{array}$ \\
\hline
\end{tabular}

Previously, only Echinolampas ovumserpentis was recorded from Trinidad, which is the type locality for that species. The few Echini recorded are in the U.S. National Museum, excepting Brissus exiguus, which was recorded by Guppy in 1911.

\section{GEOLOGICAL DISTRIBUTION.}

The table of stratigraphic and geographic distribution of fossil Echini in the West Indies includes all the species that I have had for study, and in addition the species included in Cotteau's Spanish report; species in Lambert's Report on West Indian Echini in the British Museum; species described by Michelin, or species listed by A. Agassiz as occurring fossil in the West Indies; also Echinolampas anguilla and Eupatagus abruptus (Gregory), from Barbados. It does not include a few Echini from Jamaica, reported by Desor and by R. T. Hill, for which see the list of Jamaica species (p. 6). It may be said that the list is complete for the recognizable fossil species recorded, as far as I am aware. ${ }^{4}$

Excepting where I have not had the species and the few cases marked by references to foot-notes, there have been specimens in the collections studied from each of the localities listed.

Cotteau and Lambert in their publications did not recognize the Oligocene as a formation, and it is known that some species they refer to the Miocene should be referred to the Oligocene.

${ }^{1}$ Guppy, R. J. L., Quart. Jour. Geol. Soc. London, vol. 67, p. 692, 1911.

${ }^{2}$ Gregory, J. W., Quart. Jour. Geol. Soc. London, vol. 48, pp. 163-169, pl. 4, 1892.

${ }^{3}$ Gregory described Cystechinus crassus Gregory from the Radiolarian marls of Barbados (1889, Quart. Jour. Geol. Soc. London, vol. 45, p. 640, figs. 1 to 3). This species is of such doubtful relationship that it can not be inserted in the key, p. 53, and is omitted excepting for this note. (See A. Agassiz, 1904, Mem. Mus. Comp. Zoöl., vol. 31, p. 157.)

- In foot-notes on page 9 are references to lists of West Indian fossil species of Echini that seem to be unrecognizable. 


\section{Stratigraphic and Geographic Distribution of Fossil Echini in the West Indies.}

A question mark after the name of an island or country means that the geologic horizon is doubtful.

\begin{tabular}{|c|c|c|c|c|c|}
\hline Species. & $\begin{array}{l}\text { Creta- } \\
\text { ceous. }\end{array}$ & Eocene. & Oligocene. & Miocene. & Pliocene. \\
\hline Cidaris peloria, sp. nov................ & & & $\begin{array}{l}\text { Anguilla. } \\
\text { Porto Rico. }\end{array}$ & & \\
\hline Cidaris foveata, sp. nov........... & $\ldots \ldots$ & Jamaica. & Porto kico. & & \\
\hline 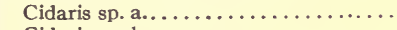 & $\ldots .$. & $\ldots \ldots \ldots \ldots$ & Porto Rico (?) & Dom. Repub. & \\
\hline Cidaris sp. b..................... & $\ldots \ldots$ & $\ldots \ldots \ldots \ldots$ & Porto Rico (?) & & \\
\hline Cidaris loveni Cotteau . . . . . . . . . . & $\ldots \ldots$ & $\begin{array}{l}\text { St. Barthol- } \\
\text { omew. }\end{array}$ & & & \\
\hline Cidaris clevei Cotteau.$\ldots \ldots \ldots \ldots \ldots$ & & $\ldots \ldots \ldots \ldots$ & Anguilla. & & \\
\hline Cidaris melitensis Wright $\ldots \ldots \ldots \ldots$ & $\ldots$. & $\ldots \ldots \ldots \ldots$ & Anguilla. & $\begin{array}{l}\text { Dom. Repub., } \\
\text { Trinidad. }\end{array}$ & \\
\hline Cidaris tribuloides (Lamarck) ........ & $\cdots$ & $x^{-1}$ & & Cuba. & \\
\hline Order CEnTREChinoidA. & & & & & \\
\hline Echinopedina cubensis Cotteau...... & & 2 Cuba (?). & & Dom.Repub. & \\
\hline${ }^{1}$ Codiopsis arnaudi Cotteau $\ldots \ldots \ldots \ldots$. & Cuba. & & & & \\
\hline $\begin{array}{l}{ }^{1} \text { Salenia scutigera (Münster) } \ldots \ldots \ldots \ldots \\
{ }^{1} \text { Phymosoma cubense (Egozcue) ....... }\end{array}$ & Cuba. & & & & \\
\hline $\begin{array}{l}{ }^{1} \text { Phymosoma cubense (Egozcue)....... } \\
\text { Echinometra prisca Cotteau ........ }\end{array}$ & Cuba. & & Cuba (?), Porto & Cuba (?) & \\
\hline Order ExocycLoIDA. & & & Rico, Anguilla. & & \\
\hline Suborder HolectypiNA. & & & & & \\
\hline $\begin{array}{r}{ }^{1} \text { Conulus antillensis }(\text { Cotteau }) \ldots \ldots \ldots \\
\text { Lanieria lanieri }(\text { Cotteau }) \ldots \ldots \ldots \ldots\end{array}$ & $\begin{array}{l}\text { Cuba. } \\
\text { Cuba. }\end{array}$ & & & & \\
\hline${ }^{1}$ Discoidea decorata Desor........... & Cuos. & & & $\begin{array}{l}\text { (?) Guade- } \\
\text { loupe. }\end{array}$ & \\
\hline $\begin{array}{c}{ }^{1} \text { Discoidea decorata Desor ............. } \\
\text { Suborder ClyypeAstrina. }\end{array}$ & Cuba. & & & & \\
\hline $\begin{array}{c}\text { Suborder Clypeastrina. } \\
\text { Sismondia antillarum Cotteau....... }\end{array}$ & & St. Barthol- & & & \\
\hline Sismondia anguillæ Cotteau. . . . . . & & $\begin{array}{l}\text { omew. } \\
\text { omartiol- }\end{array}$ & & & \\
\hline $\begin{array}{l}\text { Sismondia anguillæ Cotteau........... } \\
\text { Anomalanthus gregoryi Lambert..... }\end{array}$ & $\cdots \cdots$ & $\ldots \ldots \cdots \cdots \cdots$ & Anguilla, Antigua. & & \\
\hline Clypeaster rosaceus (Linné) ......... & & & 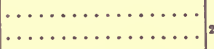 & $\begin{array}{l}\text { Antigua (?) } \\
{ }^{2} \mathrm{Cu} \mathrm{ba} \mathrm{(?),}\end{array}$ & SAnguilla. \\
\hline Clypeaster concavus Cotteau. . & & & & Porto Rico(?) & \\
\hline Clypeaster concavus Cotteau.. & & & $\begin{array}{l}\text { Cuba,Dom.Repub., } \\
\text { Porto Rico, An- } \\
\text { guilla, Antigua. }\end{array}$ & & \\
\hline Clypeaster caudatus, sp. nov......... & . . & & ................... & Dom. Repub. & \\
\hline Clypeaster dalli (Twitchell).... & & & & $\begin{array}{l}\text { Dom.Repub. (?) } \\
\text { Cuba (?) }\end{array}$ & $\begin{array}{l}\text { Dom. Re- } \\
\text { pub. (?) }\end{array}$ \\
\hline Clypeaster cubensis Cotteau.... & ... & & & Cuba (?) & \\
\hline${ }^{1}$ Clypeaster parræ Desmoulins... & $\cdots \cdots$ & & Cuba (?) & Guadeloupe. & \\
\hline Clypeaster lanceolatus Cotteau....... & . & & Cuba, Antigua. & Cuod (t) & \\
\hline Clypeaster antillarum Cotteau...... & & & Cuba, Anguilla, An- & & \\
\hline Clypeaster planipetalus Cotteau.. & & & $\begin{array}{l}\text { tigua. } \\
2 \text { Cuba, Antigua. }\end{array}$ & & \\
\hline Clypeaster cryptopetalus, sp. nov.... & ....... & & Antigua. & & \\
\hline Clypeaster cotteaui Egozcue ......... & ...... & & Cuba, ${ }^{5}$ Antigua, & & \\
\hline ' Clypeaster batheri Lambert. . & $\therefore$ & & $\begin{array}{l}\text { Jamaica. } \\
\text { Antigua. }\end{array}$ & & \\
\hline
\end{tabular}

1 This species I have not seen; authority, Cotteau, 1897, Bol. Com. Mapa Geol. Espafia, vol. 22.

${ }^{2}$ This species I have not seen from this locality; authority, Cotteau, 1897, Bol. Com. Mapa Geol. España, vol. 22.

3 This species I have not seen from this locality; authority, A. Agassiz, 1883, Mem. Mus. Comp. Zoöl., vol. 10, no. 1, pp. 88-94.

4 This species I have not seen; authority, Lambert, 1915, Mém. Soc. d'Agric. de l'Aube (Troyes), vol. 79.

b This species I have not seen from this locality; authority, Lambert, 1915, Mém. Soc. d'Agric. de l'Aube (Troyes), vol. 79 . 
Stratigraphic and Geographic Distribution of Fossil Echini in the West Indies-Continued.

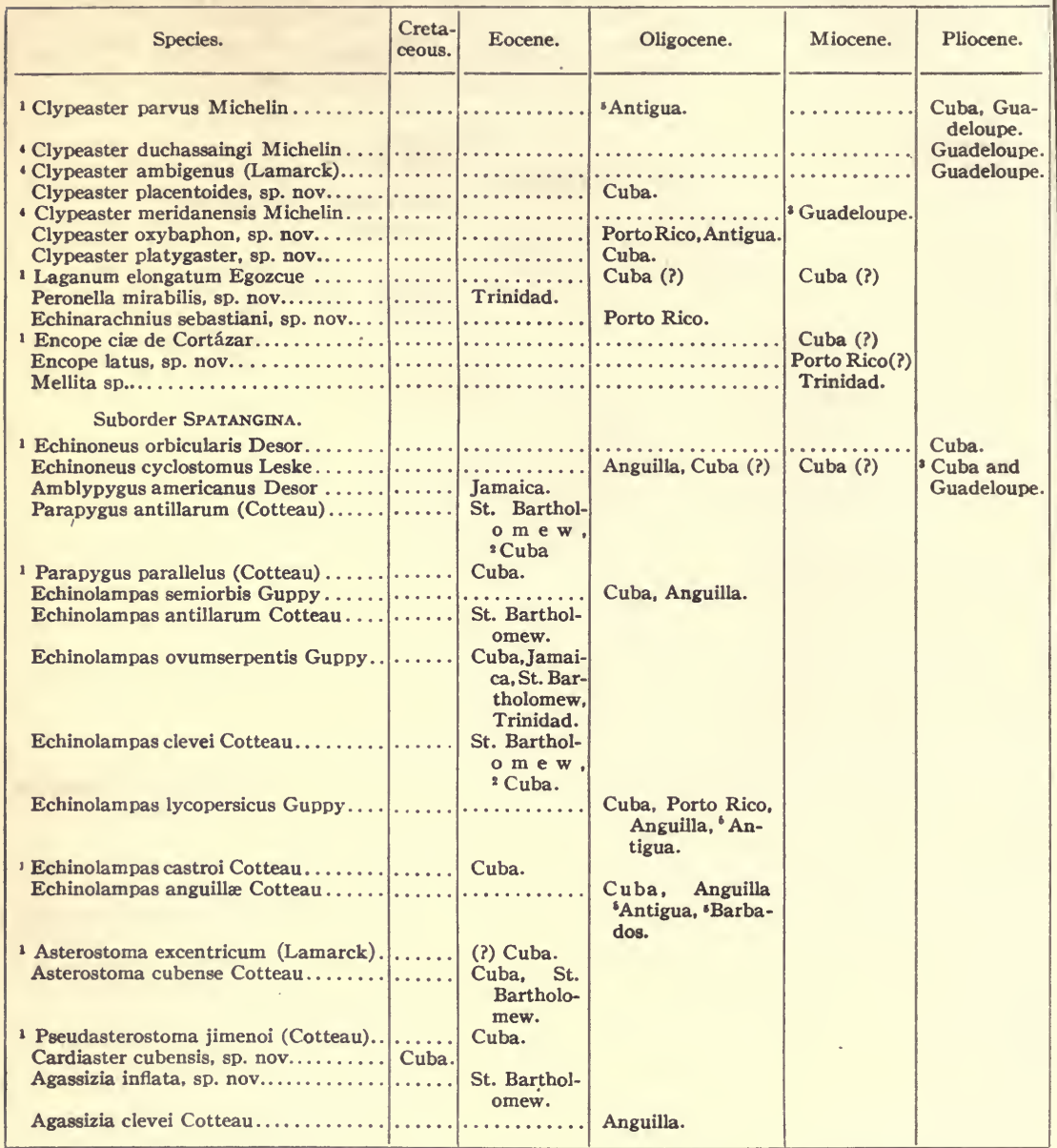

1 This species I have not seen; authority, Cotteau, 1897, Bol. Com. Mapa Geol. España, vol. 22.

- This species I have not seen from this locality; authority, Cotteau, 1897, Bol. Com. Mapa Geol. España, vol. 22.

${ }^{3}$ This species I have not seen from this locality; authority, A. Agassiz, 1883, Mem. Mus. Comp. Zoöl., vol. 10 , no. 1 , pp. 88-94.

- This species I have not seen; authority, Michelin, 1861, Mém. Soc. Géol. de France, ser. 2, vol. 7.

- This species I have not seen from this locality; authority, Lambert, 1915, Mém. Soc. d'Agric. de l'Aube (Troyes), vol. 79.

- This species I have not seen from this locality; authority, Guppy, 1911, Quart. Jour. Geol. Soc. London, vol. 67 , p. 692. 
Stratigraphic and Geographic Distribution of Fossil Echini in the West Indies-Continued.

\begin{tabular}{|c|c|c|c|c|c|}
\hline Species. & $\begin{array}{l}\text { Creta- } \\
\text { ceous. }\end{array}$ & Eocene. & Oligocene. & Miocene. & Pliocene. \\
\hline 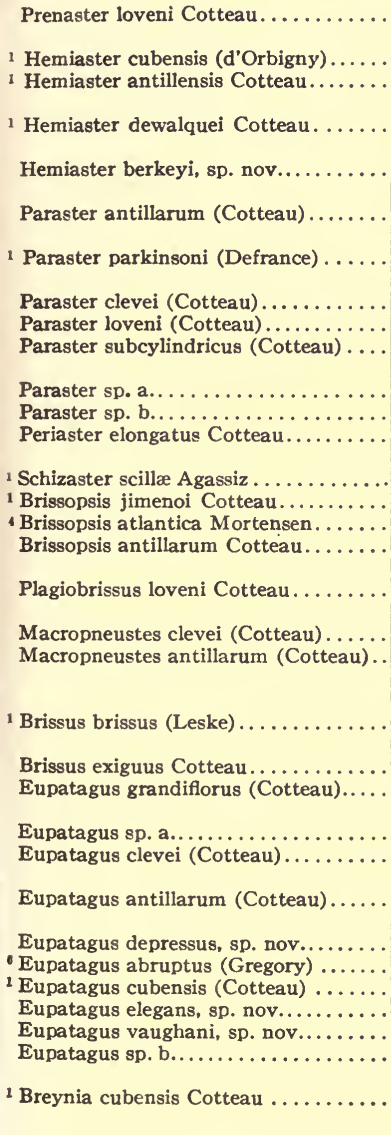 & $\begin{array}{c}\cdots \cdots \\
\cdots \cdots \\
\cdots \cdots \\
\cdots \\
\text { Porto } \\
\text { Rico. } \\
\cdots \cdots \\
\cdots \cdots\end{array}$ & 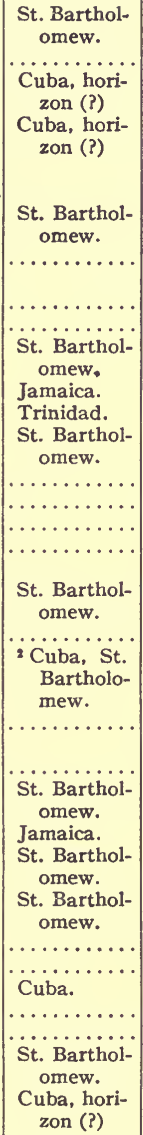 & $\begin{array}{l}\text { Cuba. } \\
\ldots \ldots \ldots \ldots \ldots \ldots \\
\text { Anguilla, } \\
\text { Dom. Repub. } \\
\text { Anguilla. }\end{array}$ & $\begin{array}{l}\text { Cuba (?) } \\
\ldots \ldots \ldots \ldots\end{array}$ & Guadeloupe. \\
\hline
\end{tabular}

1 This species I have not seen; authority, Cotteau, 1897, Bol. Com. Mapa Geol. España, vol. 22.

2 This species I have not seen from this locality; authority, Cotteau, 1897, Bol. Com. Mapa Geol. España, vol. 22.

'This species I have not seen from this locality; authority, A. Agassiz, 1883, Mem. Mus. Comp. Zoöl., vol. 10 , no. 1 , pp. 88-94.

4 This species I have not seen; authority, Lambert, 1915, Mém. Soc. d'Agric. de l'Aube (Troyes), vol. 79.

- This species I have not seen from this locality; Guppy, 1911, Quart. Jour. Geol. Soc. London, vol. 67, p. 685.

'This species I have not seen; authority, Gregory, 1892, Quart. Jour. Geol. Soc. London, vol. 48, p. 163. 


\section{SYSTEMATIC DESCRIPTIONS.}

\section{REGULAR OR ENDOCYCLIC ECHINI; THE CIDAROIDA AND CENTRECHINOIDA.}

The fossils occurring in the West Indies comprise very few of the regular or endocyclic Echini, although 7 species of cidarids occur and there are indications that more will be found; of the Centrechinoida, ${ }^{1}$ however, the remains are extremely rare, Echinometra prisca being the only species known from a considerable amount of material. In the collections studied, I have seen only one other species of the order Centrechinoida, namely, Echinopedina cubensis, from the Dominican Republic (known also from Cuba). Cotteau records 3 additional species from Cuba, not known elsewhere in the West Indies.

Key to the West Indian Families of Fossil Regular Echini, the Cidaroida and Centrechinoida. Tubercles perforate.

Ambulacra composed wholly of simple primary plates.

(Cidaroida) - Cidarida (CENTREChinolda)

(AUlodonta)

Ambulacra composed in part at least of compound plates. Tubercles imperforate.

(STIRodonta)

No primary tubercles above the ambitus.

Hemicidarida

Many primary tubercles above the ambitus.

Periproct with large suranal plate.

Saleniida

Periproct without large suranal plate.

Ambitus circular.

Phymosomatida

(Camerodonta)

Ambitus elliptical.

Echinometrida

Under the Cidaridæ 7 fossil species are recognized (see key, p. 15). Under the Pedinidæ there is only 1 fossil species, Echinopedina cubensis. Under the Hemicidaridæ there is only 1 fossil species, Codiopsis arnaudi. Under the Saleniidæ there is only 1 fossil species, Salenia scutigera. Under the Phymosomatidæ there is only 1 fossil species, Phymosoma cubensis. Under the Echinometridæ there is only 1 fossil species, Echinometra prisca.

\section{Order CIDAROIDA Duncan, I889.}

Family CIDARIDE Gray, 1825 .

Genus CIDARIS Leske, 1778.

Type species. - Echinus cidaris Linné, 1758, Sys. Nat., ed. 10, p. 664.

Of the genus Cidaris, 7 species are definitely known as described, occurring fossil in the West Indies. In addition, a few spines have been found which are not referable to any of the known species.

\footnotetext{
1 The ordinal name Centrechinoida and the family name Centrechinidæ are taken from Centrechinus, a name proposed by Jackson (1912, Phylogeny of the Echini, p. 27) to replace Diadema, which name is not available for Echini, being preoccupied.
} 
These are described without specific name and indicate that more species may be found in future, but it is not thought reasonable to base additional species on such meager material. Of the recognized species 4 have been previously described by Cotteau in his monograph; 1 species, $C$. tribuloides, is here recognized for the first time as occurring fossil in that region, although it is abundant in the living fauna throughout the West Indies; 2 species, $C$. peloria and $C$. foveata, are described as new and are quite distinct from anything previously known, either living or fossil, in that region. With the abundance of Recent cidarids in the West Indies, it is perhaps remarkable that more species and more individual specimens have not been found in the fossil condition. With the limited amount of material, no attempt has been made to refer the species to the minor generic divisions of Cidaris which are recognized in the classification of Recent species and to some extent in the fossil as well.

\section{Key to the West Indian Fossil Species of Cidaris.}

Primary spines short, thick, markedly fusiform, with large granules or spinelets, in longitudinal series or irregularly arranged............... anguilla

Primary spines very long, thick, smooth or with flutings only near the distal end .....C. peloria

Primary spines not as above or unknown. The species are separated on characters of the test.

Interambulacra with conspicuous sunken pits in median line $\ldots \ldots \ldots \ldots \ldots \ldots$ foveata

Interambulacra without such pits.

Pores of a pair in an ambulacral plate widely separated, distance between them being much greater than diameter of pore; pores of a pair connected by a furrow; coronal plates well covered with tubercles and granules. . C. Loveni

Pores of a pair in an ambulacral plate not widely separated; pores of a pair not connected by a furrow.

Coronal plates numerous ( 7 or 8 ), low and wide; areolæ not half as wide as coronal plates; scrobicular circle inconspicuous ............... clevei

Coronal plates more than 6 only in very large specimens, areolæ half as wide as plate or more; scrobicular circle inconspicuous.

Ambulacra wide (one-third to one-half width of interambulacra); coronal plates rather sparsely covered with tubercles............... melitensis

Ambulacra narrow (about one-fourth width of interambulacra); coronal plates with rather crowded tubercles.................. tribubides

\section{Cidaris anguillæ Cotteau.}

(Plate 1, Figure 1.)

Cidaris anguillee Cotteau, 1875, Kongl. Svens. Vet. Akad. Handl., vol. 13, No. 6, p. 11, plate 1, figs. 17, 18 .

Cidaris melitensis Guppy (pars), 1882, Scientific Assoc. Trinidad, Proc., part 12, p. 194.

The following is from the original description of this species:

Test unknown. Spine of medium size, elongate, cylindrical, subfusiform, provided with thorny granules, sometimes very projecting, disposed in regular longitudinal series. The extremity of the spine is truncate and the granules elongating, form small, flattened extensions, suggesting a star or corolla. Collar distinct, finely striate, ring prominent. Articular facet non-crenulate.

The Washington specimen measures $12 \mathrm{~mm}$. in length and $3 \mathrm{~mm}$. in diameter. It is somewhat shorter than Cotteau's measurement and 
does not show completely the distal tip as figured by Cotteau. It may have been broken at the tip. This species is known only from primary spines, and Cotteau mentions another specimen besides the one he figured, presumably in the Cleve collection. The Washington specimen compared with spines of melitensis shows that in anguilice the ornamenting spinelets are higher, larger, and more alternating in rows than are those of melitensis. As the spines of Cidaris clevei, which occurs in the same formation and island, are unknown, it may be that these spines should be referred to that species; but of this there is no certainty. Guppy referred both Cidaris clevei and anguilloe to melitensis as synonyms. It seems that he was quite mistaken in the case of anguille, and in the case of clevei the conclusive evidence is wanting.

Oligocene, Anguilla formation, island of Anguilla, Guppy collection ex Cleve, cotype, one spine, and indeterminable fragments of other spines on a small slab, U.S. Nat. Mus. No. 115393. Cotteau mentions a second spine of the same size, but it was not found in the Guppy collection. It is of course possible that the Washington specimen is this second spine referred to.

\section{Cidaris peloria, 1 new species.}

(Plate 1, Figures 2 to 5.)

The following is a description of this species:

Known only from primary spines and a single interambulacral plate. There are numerous primary spines, none of which, however, is complete both distally and proximally. Spines massive, circular in section, tapering gradually from just above the milled ring to the tip, which ends bluntly. Smooth throughout the length, excepting near the tip, where there are a few, 7 to 10 , low, ridged plications, the longest of these being about $15 \mathrm{~mm}$. in extent. In a few spines, which are presumably from the ventral side, the distal plications are more strongly pronounced, and there is a rounded median spinelet given off from the distal end of the spine. The largest single fragment measures $59 \mathrm{~mm}$. in length and $8 \mathrm{~mm}$. in diameter at the widest part. Another fragment, somewhat shorter but of greater thickness, measures $9 \mathrm{~mm}$. in diameter. Putting fragments together and allowing for the angle of tapering of the spine, as in plate 1, figure 5 , a complete large spine must have measured at least from 100 to $120 \mathrm{~mm}$. in length. The single interambulacral plate, which is apparently from the middle or ventral side of the test, has a high, rounded, perforate mammelon, wide scrobicular area, and relatively narrow row of marginal secondary tubercles. The plate measures $15 \mathrm{~mm}$. in width and $10 \mathrm{~mm}$. in height, $13 \mathrm{~mm}$. in width on the horizontal suture line where it came in contact with the next adjacent interambulacral plate in the vertical series.

This species evidently was very large, but there is not the evidence for making any close estimate of its size; however, comparing the single interambulacral plate with W. B. Clark's figure of the Cretaceous 
Cidaris texana W. B. Clark (1915, Monograph U. S. Geol. Survey, vol. 54, plate 9 , fig. $2 b$ ), it is very probable that the test of $C$. peloria was not less than $60 \mathrm{~mm}$. in diameter and may have been a good deal larger. No other known species in the West Indies, either living or fossil, has spines which approach those of this species either in size or character. In fact, the nearest thing to which it can be compared is the Recent Australian cidarid Phyllacanthus longispinus Mortensen. Mortensen (1918, Kongl. Sven. Vet. Akad. Handl., vol. 58, No. 9) says of this species that a specimen measures $85 \mathrm{~mm}$. in diameter and the longest primary spines measure 105 to $107 \mathrm{~mm}$. in length.

Oligocene, marly beds, base of "Arecibo" formation, Government Road, San Sebastian to Lares, km. post 33, Porto Rico, 48 specimens (including the holotype and 4 paratypes which are in the American Museum of Natural History, No. 18564), station 56. Base of "Arecibo" limestone, Government Road, San Sebastian to Lares, Porto Rico, $\mathrm{km}$. post 33, collected from north side of road from excavations where road-metal has been quarried, 1 specimen, station 58. "Arecibo" formation, Government Road, San Sebastian to Lares, Porto Rico, shaly limestone, south side of road, $\mathrm{km}$. post $33(11 \mathrm{~km}$. east of San Sebastian or $5 \mathrm{~km}$. west of Lares), 26 specimens, station 20. Collazo shales, Government Road, San Sebastian to Lares, Porto Rico, near $\mathrm{km}$. post 29, 2 specimens, station 105 . The holotype and all of the above paratypes were collected by C. A. Reeds on an expedition of the New York Academy of Sciences, the Porto Rican Government and the American Museum of Natural History coöperating.

\section{Cidaris foreata, new species.}

\section{(Plate 1, Figures 6, 7.)}

The following is a description of this species:

Test large, flattened dorsally and ventrally. Ambitus below the midzone. Ambulacra wide ( $8 \mathrm{~mm}$.), sunken; poriferous areas wide; pores oval, connected by deep furrows. The interporiferous areas are as wide as a poriferous area, deeply channeled in the median line, elevated on the borders. Interporiferous area ornamented with a series of large tubercles on the outer border of the area on each side, and a second series of smaller tubercles runs parallel to the larger tubercles and just within the same. There are also 2 or 3 miliary tubercles on each plate near the center of the area. The ambulacral areas are quite straight dorsally, but sinuous below the mid-zone. About 12 ambulacral plates equal the height of an interambulacral plate at the mid-zone. Interambulacral plates with large prominent tubercles, which are mammillate, perforate, deeply crenulate, with high and wide scrobicular areas which extend dorsally and ventrally nearly to the borders of the plate. A row of secondary tubercles surrounds the primaries, and minute miliary tubercles are abundant toward the middle line of the area on each plate. There are 10 interambulacral plates in a column. The most striking features of the interambulacra and also of the species is a series of deep pits in the median line of each area. These 
pits occupy a position at the admedian apex of each interambulacral plate, so that in each plate there are 3 pits, one in the middle line and one at the point of both its upper and lower margins where it comes in contact with the borders of the next adjacent interambulacral plates.

Height of the test $34 \mathrm{~mm}$., diameter $54 \mathrm{~mm}$., diameter of the periproct and peristome about $15 \mathrm{~mm}$.

This species is entirely distinct from any other known cidarid occurring either fossil or living in the West Indies. It is characterized by the size of the test, which is larger than any other fossil species at present known (though the test of Cidaris peloria, which is unknown, was probably even larger), by the very broad poriferous areas with deep connecting furrows, by the deeply channeled interporiferous area, and especially by the deep pits which mark the interambulacral areas. These pits are comparable to those seen in Goniocidaris tubaria (Lamarck) of the Australian region, but with the difference that they are more deeply marked in $C$. foveata and do not run together in grooves as they do in G. tubaria. This is still another case of a fossil West Indian species finding its nearest living ally in eastern Pacific waters. It is associated in the same lot, evidently from the same locality with the Echinolampas ovumserpentis, Paraster sp. $a$, and Eupatagus sp. $a$ as here described.

Eocene, from yellowish limestone, probably the Cambridge formation of R. T. Hill, Jamaica, with no detailed locality; one specimen, holotype, Mus. Comp. Zoöl. No. 3234.

Cidaris species a. (Text-figure 1.)

The following is a description of this specimen:

Primary spine long, slender, acicular, with 8 to 10 rows of low denticulate ridges running parallel to the longer axis. The most perfect spine, which is very nearly entire proximally, showing indications of the milled ring and collar. It is incomplete distally. As far as preserved, it measures $13 \mathrm{~mm}$. in length and $2 \mathrm{~mm}$. in diameter at about the middle of its total length.

This species is represented by one fairly complete spine and a second fragmentary one on a slab of soft yellow limestone. It differs from any other known species of Cidaris occurring fossil in the West Indies, but makes a very close approach in character to the Recent West Indian species Dorocidaris rugosa H. L. Clark (1907, Bull. Mus. Comp. Zoöl., vol. 51, No. 7, p. 210 , plates 4,5 ).

Geologic age not known, probably Miocene, Ponce

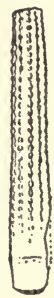

1.-Cidaris sp.a. Spine, $\times 3$. Chalk, $2 \mathrm{~km}$. southwest of Juana Diaz, from fallen block of limestone alongside of the irrigation flume on flood-plain of the Jacaguas River, Porto Rico, station 195, American Mus. Nat. Hist. No. 18565, C. A. Reeds collector, Expedition of the New York 
Academy of Sciences, the Porto Rican Government and the American Museum of Natural History coöperating. A Cidaris spine closely similar occurred in the Miocene, Gurabo formation at Rio Mao, half a mile above ford at Cercado de Mao, Dominican Republic, T. W. Vaughan and C. W. Cooke collectors, one spine, U. S. Geol. Sur. station 8519.

Cidaris species b. (Text-figures 2, 3.)

The following is a description of these specimens:

Spines small, cylindrical, tapering gradually from above the collar, or contracted above the collar and thence tapering distally. Both specimens are complete proximally, showing the milled ring and collar, but wanting at the distal tip. Thickly and irregularly set with thornlike spinelets which stand out nearly at right angles to the axis, or with fewer and larger spinelets, which again are nearly at right angles to the axis. The specimen with smaller and numerous spinelets and which is nearly complete distally, measures $15 \mathrm{~mm}$. in length by $3 \mathrm{~mm}$. in its greatest diameter. The one with two large spinelets, which is larger, is of undeterminate length, but measures $3.5 \mathrm{~mm}$. in diameter.

This species is quite distinct from any other known, living or fossil, in the West Indies. It can be compared, however, very closely with Goniocidaris biserialis Döderlein (1887, Die Japanischen Seeigel, Stuttgart, plate 5), which has similar and very variable spines. It is interesting that 3 species of fossil Cidaris in the West Indies, C. peloria, C. foveata, and the present one, find their closest analogy in Recent Eastern Pacific forms.
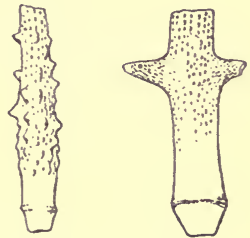

2, 3.-Cidaris sp. b:

Spines, $\times 2$.

Geologic age not known, Arecibo limestone, weathered marl, Government Road, Aguadilla to Rincon, Porto Rico, $\mathrm{km}$. post 2, from roadside grottoes where road-metal had been taken out, 2 specimens, station 117, American Mus. Nat. Hist. No. 18566, C. A. Reeds collector, Expedition of New York Academy of Sciences, the Porto Rican Government and the American Museum of Natural History coöperating.

\section{Cidaris loveni Cotteau.}

(Plate 1, Figures 8 to 10.)

Cidaris loveni Cotteau, 1875, Kongl. Svens. Vet. Akad. Handl., vol. 13, No. 6, p. 10, plate 1, figs. 11 to 14. Guppy, 1882, Scient. Assoc. Trinidad, Proc., part 12, p. 195.

The following is an extract from the original description of this species:

This species is of medium size, subcircular, slightly pentagonal, nearly equally flattened above and below. Ambulacral areas sunken, relatively wide, subundulate, nearly straight dorsally and ventrally. Pores oval, very open, disposed nearly horizontally, each pair separated by a transverse swelling, at first sight like the pores of Rhabdocidaris, but this resemblance 
is more apparent than real. The interporiferous areas are very broad, with two rows of regular granules placed on the border of the poriferous areas, the intermediate space occupied by two other ranges of finer granules, less regularly arranged and less equal in size. Interambulacral tubercles prominent, strongly mammillate, perforate, non-crenulate. Scrobicules moderately developed, rounded dorsally, subelliptical as one approaches the peristome, bordered with a circle of mammillate granules, the space without this circle being covered with smaller tubercles, irregular and rather widely scattered.

Height of specimen $15 \mathrm{~mm}$., diameter $26.5 \mathrm{~mm}$., width of ambulacrum at the mid-zone $4 \mathrm{~mm}$., width of interambulacrum at the same plane $12 \mathrm{~mm}$. Cotteau says that there are 6 interambulacral plates in a column, but I found that, in some areas at least, there are 7; they are, however, very incomplete and worn dorsally.

This species is easily distinguished from the other fossil species of Cidaris of the region by the widely separated ambulacral pores of a pair connected by a furrow, as in the living genus Phyllacanthus. When compared with an adult Recent Cidaris bartletti (A. Ag.) from Barbados (M. C. Z. No. 133), the differences are slight, the only tangible one being the more numerous tubercles and granules on the coronal plates. About 12 ambulacral plates at the mid-zone abut against a single interambulacral plate. Interambulacrum with 6 plates in a column, as stated by Cotteau, though in one area at least 7 existed, as I counted that number. Interambulacral plates prominent, strongly mammillate, non-crenulate. This species, loveni, although of considerable antiquity geologically, is certainly very similar to the Recent bartletti.

Cotteau does not mention more than one specimen of this species and only says very rare. The specimen gives the same measurements as Cotteau's, and while in part much worn, it is evidently the holotype of which Cotteau's figures were quite freely restored, especially in the dorsal view.

Eocene, St. Bartholomew limestone, island of St. Bartholomew, Guppy Collection ex Cleve, holotype, 1 specimen, U. S. Nat. Mus. No. 115415.

Cidaris clevei Cotteau.

(Plate 1, Figure 11.)

Cidaris clevei Cotteau, 1875, Kongl. Svens. Vet. Akad. Handl., vol. 13, No. 6, p. 11, plate 1, figs. 15, 16.

Cidaris melitensis Guppy (pars), 1882, Scient. Assoc. Trinidad, Proc., part 12, p. 194.

The following is an extract from original description of this species :

Species of small size, circular, moderately elevated, ambulacra narrow, straight, slightly sunken, ambulacral area with 6 rows of granules nearly equal in size, the 6 rows being reduced to 4 ventrally and dorsally. Interambulacral tubercles small, perforate, non-crenulate, 7 to 8 plates in a column. Scrobicules small, narrow, never meeting at the base. Space around scrobicules filled with small granular tubercles. 
This species was based by Cotteau on a single specimen which consists of an interambulacral area with a half-ambulacrum on either side. The specimen measures $9.5 \mathrm{~mm}$. in height. The width of the interambulacrum at the mid-zone is $6 \mathrm{~mm}$. and of each half-ambulacrum $1.5 \mathrm{~mm}$. As the width of an interambulacrum plus an ambulacrum at the mid-zone equals $9 \mathrm{~mm}$., the circumference of a complete specimen of the same size would be about $45 \mathrm{~mm}$. and the diameter as estimated about $14 \mathrm{~mm}$. The species is characterized by its low and wide coronal plates and also by the fact that the areolæ are so small that their horizontal diameter is less than one-half the horizontal width of the plate. On the other hand, in most West Indian cidarids, the horizontal diameter of the areolæ at the mid-zone is more than half the width of the plate. Again, in clevei, the surface of the coronal plates outside the areolæ is rather uniformly tuberculated, and there is a conspicuous scrobicular circle of secondary tubercles. Cotteau says there are 7 to 8 interambulacral plates in a series (column); 7 were counted on the specimen; and a space for probably 1 additional plate exists against the ambulacrum. There is no evidence, however, for 9 plates in a column as shown in the right half of Cotteau's figure.

Oligocene, Anguilla formation, from the island of Anguilla; holotype and only known specimen, Guppy collection ex Cleve, U.S. Nat. Mus. No. 115400.

Cidaris melitensis Wright.

(Plate 1, Figures 12 to 17.$)$

Cidaris melitensis Wright, 1855, Ann. Mag. Nat. Hist., ser. 2, vol. 15, p.107, plate 4, figs. $1 a$ to $c$. Guppy, 1866, Quart. Jour. Geol. Soc. London, vol. 22, p. 299. Cotteau, 1875, Kongl. Sven. Vet. Akad. Handl., vol. 13, No. 6, p. 8, plate 1, figs. 1 to 10. Guppy, 1882, Scient. Assoc. Trinidad, Proc., part 12, p. 194.

The following is an extract from Cotteau's description of this species:

Species of medium size, circular, about equally depressed dorsally and ventrally. Ambulacral areas relatively broad, a little depressed, subundulate. Pores rounded, very open, disposed a little obliquely, each pair of pores separated by a small elevation. Interporiferous areas very narrow toward the poles, with 2 principal rows of granules near the pores and with 2 vertical rows of smaller tubercles in each half-area at the ambitus. Interambulacral tubercles prominent, strongly mammillate, perforate, non-crenulate. Scrobicules large, subelliptical toward the peristome, tending to become circular dorsally, bordered with a regular circle of small mammillate granules. Beyond this circle the plates are rather sparingly covered with small granules. Peristome subcircular, periproct subpentagonal, and Cotteau says a little larger than the peristome. Spines elongate, cylindrical, acuminate distally, furnished with granules disposed in longitudinal series, more prominent toward the base. The upper end of the spine appears to be quite smooth.

In the U.S. National Museum there are 2 specimens of tests and 3 spines which are evidently the originals of Cotteau's figures. In 
Cotteau's figure of the larger specimen he has restored the outlines so as not to show the lateral crushing. The larger crushed test measures $15 \mathrm{~mm}$. in height, $17.5 \mathrm{~mm}$. across the plane of crushing, and $26 \mathrm{~mm}$. in the plane of crushing at the mid-zone (plate 1, fig. 12). The width of an ambulacrum at the mid-zone is $3.5 \mathrm{~mm}$. and of an interambulacrum is $9 \mathrm{~mm}$. Eight ambulacral plates abut against an interambulacral plate at the mid-zone. In this specimen there are 6 interambulacral plates in a column in each area. As noted in the description, Cotteau says that the periproct is a little larger than the peristome, but as far as one can judge in their somewhat crushed condition, it appears that they are practically of the same size. In the smaller specimen, which is not crushed at all, the periproct and peristome are of the same size. This matter of similar size of periproct and peristome is a good character to distinguish melitensis from the nearly allied $C$. tribuloides, in which the peristome is larger than the apical disk. The smaller test is better preserved, not being compressed. It measures $9 \mathrm{~mm}$. in height and $17 \mathrm{~mm}$. in diameter; width of ambulacrum $2.5 \mathrm{~mm}$., of interambulacrum $7 \mathrm{~mm}$. The diameters of the periproct and peristome measure about $8 \mathrm{~mm}$. each. In this smaller specimen there are either 5 or 6 plates in each interambulacral column, in some columns the sixth plate not yet having appeared, whereas the larger specimen had 6 plates in each column. The youngest plates dorsally bear tubercles, but they have not yet developed perforations, this being the typical character of young plates dorsally in Cidaris. The spines measure up to $20.5 \mathrm{~mm}$. in length and $3 \mathrm{~mm}$. in diameter at the widest part.

In addition to the above, there are in the U. S. National Museum 3 fragmentary tests in the Guppy collection which probably were not collected by Cleve or studied by Cotteau. They have 5 or 6 plates in each interambulacral column, and one of them shows apophyses of the perignathic girdle for the attachment of lantern muscles.

Cidaris melitensis is closely allied to $C$. tribuloides, but is at once distinguished by its much more sparsely tuberculated coronal plates and wider ambulacra; also by the fact that in melitensis the peristome and apical disk are practically of the same diameter, whereas in tribuloides the peristome is much wider than the apical disk.

Oligocene, Anguilla formation, island of Anguilla, Guppy collection ex Cleve, 2 tests and 3 spines, evidently the originals of Cotteau's plate 1, figs. 1-10, U. S. Nat. Mus. No. 115399. Anguilla, Guppy collection, 3 fragmentary tests, U.S. Nat. Mus. No. 115412. Miocene, a single fragmentary spine, evidently referable to this species from (loc. 11) Mayo Village Quarry, Trinidad, F. W. Penny collector, U. S. Geol. Sur. station 8583. Miocene, 2 small spines 12 and $14 \mathrm{~mm}$. long respectively, apparently attributable to this species, are from the Gurabo formation, Rio Mao, one-half mile above ford at Cercado 
de Mao, Dominican Republic, T. W. Vaughan and C. W. Cooke collectors, U. S. Geol. Sur. station 8519.

$$
\begin{aligned}
& \text { Cidaris tribuloides (Lamarck). } \\
& \text { (Plate 1, Figures } 18 \text { to 20.) }
\end{aligned}
$$

Cidarites tribuloides Lamarck, 1816, Anim, sans Vert., vol. 3, p. 56.

The following is a description of this species:

Test moderate-sized, circular, ambulacra flush, very narrow; pores in ambulacral plates crowded; interporiferous areas narrow with crowded tubercles. Interambulacral plates with prominent tubercles and very large areolæ; space around scrobicules densely packed with small tubercles. Diameter of peristome much greater than that of the apical disk.

This Recent species, which is abundant in the living fauna of the West Indies, has not been previously recorded as occurring fossil in that region. Two finely preserved tests in the U.S. National Museum are clearly referable to the species. The larger of the two measures $17 \mathrm{~mm}$. in height, $29 \mathrm{~mm}$. in diameter; width of ambulacrum at the mid-zone $4 \mathrm{~mm}$.; width of interambulacrum at the mid-zone $13 \mathrm{~mm}$. The diameter of the periproct is $11 \mathrm{~mm}$. and the diameter of the peristome is $14 \mathrm{~mm}$. There are 6 or 7 plates in each interambulacral column, and the same is true of the smaller specimen.

Cidaris tribuloides is close to $C$. melitensis, but differs from that species as there described, the main features of difference being the narrow ambulacra, crowded ambulacral pores, and the greater diameter of peristome than apical disk in tribuloides. This species occurred in the same lot with Echinometra prisca and Echinoneus cyclostomus, both of which are found in the Oligocene of Anguilla, all as stated under those species.

Miocene (?), Santiago de Cuba, received January 29, 1910, 2 complete tests and 3 fragmentary tests, U. S. Geol. Sur. station 5255, U. S. Nat. Mus. No. 328221.

\section{Order CENTRECHINOIDA Jackson, rgr2. \\ Suborder AULODONTA Jackson, 1912. \\ Family PEDINIDEE Gregory, r9oo. \\ Genus ECHINOPEDINA Cotteau, I866.}

Type species.-Echinopsis gacheti Agassiz, 1846, Catalogue Raisonné, Ann. Sci. Nat., ser. 3, vol. 6, p. 355.

\section{Echinopedina cubensis Cotteau.}

(Plate 2, Figure 1.)

Echinopedina cubensis Cotteau, 1881, Annal. Soc. Géol. de Belgique, vol. 9, p. 9, plate 1, figs. 1 to 6; 1897, Bol. Com. Mapa Geol. España, vol. 22, p. 16, plate 2, figs. 1 to 6.

Regular Echini other than the Cidaroida appear to be extremely rare as fossils in the West Indies, while a few have been described 
by Cotteau, in the collections that I have seen, only two species occurred, namely, Echinometra prisca and one other which is provisionally placed here.

The specimen here described is so much worn that it is not certain what the species is, yet it shows a good many characters worth recording. Test circular, low, rounded, dome-shaped, flattened on the lower side; ambulacral plates narrow, compound; the pores in arcs of 3 pairs to each plate; interambulacra twice the width of the ambulacra at the mid-zone. The surface of the test is so worn that while sutures can be made out, no external characters are retained. Genital and ocular plates are in place, and though indistinct, the genitals apparently meet in a ring, shutting out the oculars from the periproct. Height of specimen $13 \mathrm{~mm}$., diameter $29 \mathrm{~mm}$.

Miocene, Gurabo formation, Rio Gurabo, above Gurabo Adentro, District of Monte Christi, Dominican Republic; T. W. Vaughan and C. W. Cooke collectors, May 1919, 1 specimen, U. S. Geol. Sur. station 8547, U. S. Nat. Mus. No. 328232. Cotteau gives as locality in his original description, Cienfuegos, Cuba, and ascribes this species to the Eocene.

Family HEMICIDARID $\&$ Wright, 1857.

Genus CODIOPSIS Agassiz, 1840.

Type species.-Echinus doma Defrance, 1825, Dict. Sci. Nat., vol. 37, p. 101.

\section{Codiopsis arnaudi Cotteau.}

Codiopsis arnaudi Cotteau, 1862-67, Paléontologie Française, vol. 7, p. 786, plate 1192. figs. 12 to18; 1897, Bol. Com. Mapa Geol. España, vol. 22, p. 14, plate 1, figs. 10 to 15.

This species was originally described from the Cretaceous of France. I have not seen any West Indian material, but Cotteau ascribes to this species a specimen from the Cretaceous of Santa Lucia, Province of Santa Clara, Cuba.

\section{Suborder STIRODONTA Jackson, 1912.}

Family SALENIDE Duncan and Sladen, 1887.

Genus SALENIA Gray, 1835 .

Type species.-Cidarites scutigera Münster in Goldfuss, 1829, Petrefacta Germaniæ, vol. 1 , p. 121 , plate 49 , figs. $4 a, 4 b$.

\section{Salenia scutigera (Münster).}

Cidarites scutigera Münster, loc. cit.

Salenia scutigera Cotteau, 1897, Bol. Com. Mapa Geol. España, vol. 22, p. 8, plate 1, figs. 1 to 3.

To this species, described from the Cretaceous of Europe, Cotteau refers a single specimen from the Cretaceous of Santa Lucia, Province of Santa Clara, Cuba, Coll. Comisión del Mapa Geológico de España. 
Family PHYMOSOMATDE Meissner, 1903.

Genus PHYMOSOMA Haime, 1853.1

Type species.-Cidaris konigii Mantell, 1822, Geology of Sussex, p. 189.

\author{
Phymosoma cubense (Egozcue).
}

Cyphosoma cubense Egozcue in Cotteau, 1897, Bol. Com. Mapa Geol. España, vol. 22, p. 12, plate 1 , figs. 4 to 9 .

Cretaceous, ingenio Concepción de Montalvo, Cienfuegos, Province of Santa Clara, Cuba, very rare, collection of Comisión del Mapa Geológico de España, Madrid.

\title{
Suborder CAMERODONTA Jackson, I912. \\ Family ECHINOMETRIDE Gray, 1855 . \\ Genus ECHINOMETRA Gray, 1825 .
}

Type species.-Echinus lucunter Linné, 1758, Sys. Nat., ed. 10, p. 665.

\section{Echinometra prisca Cotteau.}

(Plate 1, Figures 21 to 24.)

Echinometra acufera Guppy (non Blainville), 1866, Quart. Jour. Geol. Soc. London, vol. 22, p. 299.

Echinomelra prisca Cotteau, 1875, Kongl. Sven. Vet. Akad. Handl., vol. 13, No. 6, p. 12, plate 1, figs. 19 to 27. Guppy, 1882, Scient. Assoc. Trinidad, Proc., part 12, p. 195.

The following is an extract from the original description of this species:

Species of relatively small size, elongate, oblique. Upper face moderately swollen, lower face slightly hollowed. Ambulacral areas straight dorsally, subundulate at the ambitus and ventrally. Pores small; rounded, in arcs of 3 or 4 pairs. Ambulacral areas wide, with 2 rows of tubercles which are strongly mammillate, regularly disposed, diminishing in size toward the peristome and apical disk. Space between the 2 rows of tubercles occupied by some granules irregularly disposed. Interambulacral areas with 2 rows of prominent tubercles similar to those of the ambulacral areas, a little more developed, however, especially dorsally. Accompanying these primary tubercles are 4 rows of secondary tubercles, 1 on each side of the ambulacral areas and 2 in the miliary zone. The secondary tubercles, which are much smaller than the others, especially those which occupy the middle of the miliary area, form incomplete ranges, a little irregular, which disappear dorsally and before arriving at the peristome. The granules which accompany these are very unequal and are placed without order, tending, however, to group themselves around the tubercles of the upper side. Peristome very large, subcircular, a little oval, with weak cuts, strengthened on the border.

The largest specimen from Anguilla measures $16 \mathrm{~mm}$. in height, $33.5 \mathrm{~mm}$. in length, and $27.5 \mathrm{~mm}$. in width. A smaller specimen, very well preserved, also from Anguilla, measures $11 \mathrm{~mm}$. in height, 24.5

1 The name Cyphosoma for the genus was preoccupied for Coleoptera and the name Phymosoma of Haime was substituted by A. Agassiz, Revision of the Echini, pt. 1, p. 151. 
$\mathrm{mm}$. in length, and $19 \mathrm{~mm}$. in width. The large specimen mentioned shows the auricles extending vertically and joined in suture over the ambulacrum as usual in the genus. The species superficially resembles Echinometra lucunter, which is abundant in the living West Indian fauna, but so far has not been found fossil. It differs strongly in that lucunter has pore-pairs in arcs of 7 to 8 pairs in each plate, whereas prisca has only 3 or 4 pairs to a plate. Some specimens show 3 only, as far as preserved, others show 3 or 4 pore-pairs, and a specimen from Cuba (station 5255) shows 4 pairs to a plate throughout. Cotteau's figure 22 of an ambulacrum, enlarged, shows 3 pore-pairs only to a plate. The ambulacra in lucunter widen to the peristomal border, whereas in prisca they become narrow at this area. These two are sufficient characters to separate the two species, which at first sight look alike.

Echinometra prisca with its few pore-pairs is a very primitive species in the genus, being comparable to the young of lucunter and other species. Moreover, it is the only species of the genus occurring fossil, as far as I am aware. The Recent species of Echinometra have from 4 to 8 or 9 pore-pairs to a plate, and it is most interesting that this fossil species with only 3 or 4 pairs to a plate makes such an approach to the next lower family, the Echinidæ, which is characterized by 3 pore-pairs to a plate.

The feature of the pore-pairs in the ambulacral plates of Echinometra prisca, as described, is in direct accord with the important principle that in a genetic series the characters in the young of a higher group and also in the geologically oldest members of the higher group make a close approach to the characters of the adults of a more primitive group in a phylogenetic series.

Oligocene, Anguilla formation, island of Anguilla, Guppy collection ex Cleve, 8 specimens, cotypes, U. S. Nat. Mus. No. 115398. Anguilla, Guppy collection, 4 specimens, U. S. Nat. Mus. No. 115414. Road Bay, south side, near western end of point on north side of Bay, Anguilla, T. W. Vaughan collector, 1914, 1 specimen, U. S. Geol. Sur. station 6969a. Geologic age doubtful, Santiago de Cuba, 1 specimen, U. S. Geol. Sur. station 5255, U. S. Nat. Mus. No. 328222. Cliff face, east shore of Guanica Harbor, Porto Rico, 300 feet south of small cave of station 341 ; the beds are a shaly limestone, somewhat stratified, 1 specimen, C. A. Reeds collector, station 375, Expedition of the New York Academy of Sciences, the Porto Rican Government and the American Museum of Natural History coöperating. 


\section{IRREGULAR OR EXOCYCLIC ECHINI.}

\section{THE EXOCYCLOIDA.}

While the regular or endocyclic Echini occurring fossil in the West Indies are very rare for the most part and represented by but very few species outside of the Cidaridæ, on the other hand the exocyclic Echini are abundant in species and often in individuals. With but few holectypoids, the clypeastroids are abundant in species and individuals, and there are many species of spatangoids.

Clypeastroids usually have thick, solid tests well adapted for preservation as fossils; but spatangoids, on the other hand, often have thin, delicate tests which, as fossils, are frequently crushed beyond recognition.

Key to the West Indian Fossil Suborders of Exocycloida.

Peristome central, jaws present.

Ambulacral plates compound or largely simple, areas non-petaloid dorsally; ambitus oval or circular, but test when circular is not discoidal............ HoLECTYPINA

Ambulacral plates simple, areas petaloid dorsally; when the ambitus is circular the

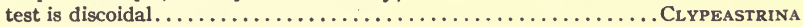

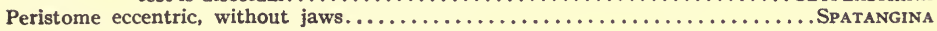

The Holectypina are represented in the fossil West Indian fauna by only 3 genera and the same number of species. The Clypeastrina are represented by 8 genera and numerous species. The Spatangina are represented by 19 genera and numerous species.

\section{Order EXOCYCLOIDA Jackson, 1912.}

\section{Suborder HOLECTYPINA Gregory, I900.}

Key to the West Indian Fossil Species of Holectypina.

Ambitus oval; periproct marginal or supramarginal.............. Conulus antillensis Ambitus circular; periproct on oral surface.

Test high, vertical diameter not much less than horizontal diameter; periproct broadly oval. Genital 2 much larger than other genitals.... Lanieria lanieri

Test depressed, vertical diameter only about 60 per cent of horizontal diameter; periproct narrowly elliptical. Genital 2 not much larger than other

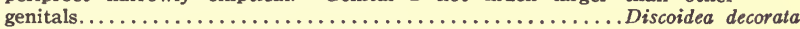

\section{Genus CONULUS Leske, 1778.}

Type species.-Conulus albogalerus Leske, 1778, Add. ad Klein, p. 98.

The name Echinoconus, a pre-Linnæan name, gives way to Conulus Leske, which is the name first used after Linnæus. Galerites of Lamarck is the same thing, but is a later name than Conulus and therefore becomes a synonym.

\section{Conulus antillensis (Cotteau).}

Echinoconus antillensis Cotteau, 1881, Ann. Soc. Géol. Belgique, vol. 9, p. 13, plate 2, figs. 1,$2 ; 1897$, Bol. Com. Mapa Geol. España, vol. 22, p. 21, plate 3, figs. 1, 2.

Cotteau says that this species is known only from a single specimen, which he attributes to the Cretaceous. Cienfuegos, Cuba, collection of M. Moens, in Lede. 
Genus LANIERIA Duncan, 1889.

Type species.-Echinoconus lanieri Cotteau, 1881, Ann. Soc. Géol. Belgique, vol. 9, p. 11.

\author{
Lanieria lanieri (Cotteau).
}

(Plate 2, Figures 2 to 5.)

Echinoconus lanieri Cotteau, 1881, Ann. Soc. Géol. Belgique, vol. 9, p. 11, plate 1, figs. 7 to 13. A. Agassiz, 1883, Mem. Mus. Comp. Zoöl., vol. 10, No. 1, p. 88. Cotteau, 1897, Bol. Com. Mapa Geol. España, vol. 22, p. 19, plate 2, figs. 7 to 13.

Lanieria lanieri Hawkins, 1913, Geol. Mag., vol. 10, p. 200, figs. A, B.

The following is an extract from the original description of this species:

Species of small size, high, circular, globular; upper face rounded, sometimes subconical; lower face flattened around the peristome. Ambulacra straight, a little more than half the width of the interambulacra; ambulacral pores very small, close together, separated by a small elevation, very directly superposed, showing toward the ambitus and as far as the peristome a tendency, more or less pronounced, to group themselves in triple pairs. Tubercles small, crenulate, perforate, increasing in size on the ventral face, disposed in horizontal and vertical series, somewhat irregular, and the number varying with the size of the individual. The space between the tubercles is occupied by granules grouped around the scrobicules. Peristome small, circular, central; periproct large, elliptical, acuminate on its adapical border, situated on lower face, very near the peristome. Apical disk prominent, pentagonal, with very large genital pores; the madreporite extending to the center of the disk which it fills; ocular plates small, triangular, separating the genitals and broadly in contact with the extended madreporite.

Of this very pretty species there are 4 specimens in the Philadelphia Academy of Natural Sciences. The largest of these measures $18 \mathrm{~mm}$. in height and $23 \mathrm{~mm}$. in diameter. Another and more globular specimen measures $17 \mathrm{~mm}$. in height and $19.5 \mathrm{~mm}$. in diameter. This species has been attributed to d'Orbigny, who gave the name Galerites lanieri on plates of fossils of Cuba, but as Cotteau says that the plates were never published, it is evidently a manuscript name and the species should be attributed to Cotteau as above. Hawkins gives an interesting study of this species, and selects one of Cotteau's figured specimens as the type. This specimen, which was in the Dewalque collection, is now in the British Museum (E. 4570).

Cretaceous, Cuba, T. A. Conrad collector, 4 specimens, Philadelphia Academy Nat. Sci. No. 1505 . There is no detailed locality with the Philadelphia specimens, but Cotteau gives the locality Cienfuegos, Cuba, which in his original publication he considers Eocene. In the Spanish report, however, he refers it to the Cretaceous. He cites material from the collections of Dewalque in Liége, Vidal in Barcelona, Cotteau in Paris, and Comisión del Mapa Geológico in Madrid. A. Agassiz lists the species as occurring in the Miocene of Guadeloupe, which is probably a mistake. 
Genus DISCOIDEA Gray, 1825 .

Type species.-Echinites subuculus Leske, 1778, Add. ad Klein, p. 107.

Discoidea decorata Desor.

Discoidea decorata Desor, 1842, Monog. des Galerites, p. 63, plate 8, figs. 1 to 3. Cotteau, 1897, Bol. Com. Mapa Geol. España, vol. 22, p. 23, plate 12, figs. 1 to 7.

Occurring in the Cretaceous of Europe, this species is also found fossil in the West Indies.

Cretaceous, Cienfuegos, province of Santa Clara, island of Cuba. Many specimens in the collection of Comisión del Mapa Geológico de España, Madrid.

\section{Order EXOCYCLOIDA Jackson, I912.}

Suborder CLYPEASTRINA Gregory, I900.

Key to the West Indian Fossil Genera of Clypeastrina.

Test without lunule or marginal slits.

Madreporic pore single, test very small and flattened ............. Sismondia

Madreporic pores several or many.

Poriferous areas of petals divergent, not incurved distally....... Anomalanthus

Poriferous areas of petals more or less incurved distally.

Test high, or if flattened, with thickened margins; petals broad, of ten rounded or

truncate at tip; auricles separate.................. Clypeaster

Test flat; auricles fused into one piece.

Petals narrow and pointed.

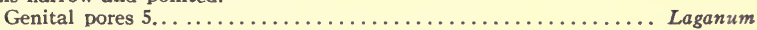

Genital pores $4 \ldots \ldots \ldots \ldots \ldots \ldots \ldots \ldots \ldots \ldots \ldots \ldots$ Peronella

Petals wide, blunt, more or less widely open at tip............ Echinarachnius Test fiat, with lunules or marginal slits and notches.

Genital pores 5; test tending to be heavy, and lunules (or marginal notches) wide.. Encope

Genital pores 4 ; test very flat, tending to be fragile, with lunules narrow.........Mellita

Of the genera of the Clypeastrina found fossil in the West Indies, the following number of species have been recognized:

Under Sismondia there are 2 fossil species (see Key, p. 29).

Under Anomalanthus there is only 1 fossil species, Anomalanthus gregoryi.

Under Clypeaster there are 19 fossil species (see Key, p. 32).

Under Laganum there is only 1 fossil species, Laganum elongatum.

Under Peronella there is only 1 fossil species, Peronella mirabilis, sp. nov.

Under Echinarachnius there is only 1 fossil species, Echinarachnius sebastiani, sp. nov.

Under Encope there are 2 fossil species (see Key, p. 50).

Under Mellita there is only 1 fossil species.

\section{Family FIBULARIIDAE Gray, 1855 . \\ Genus SISMONDIA Desor, $185^{8}$.}

Type species.-Scutella occitana Defrance, 1827, Dict. Sci. Nat., vol. 48 , p. 231.

Key to the West Indian Fossil Species of Sismondia.

Test very flat, petals somewhat pointed at tip.................... antillarum

Test moderately high (height equals one-third of length); petals blunt, open...... S. anguilla 
Sismondia antillarum Cotteau.

(Plate 2, Figures 6, 7.)

Sismondia antillarum Cotteau, 1875, Kongl. Sven. Vet. Akad. Handl., vol. 13, No. 6, p. 17, plate 3, figs. 1 to 4 .

The following is an extract from the original description of this species:

Species of small size, rounded, slightly pentagonal, a little angular anteriorly. Upper face nearly flat, thickened on the border, subdepressed around ambulacral petals; apical disk central. Ambulacral petals short, narrow, subcostulate, closed at the tips. Ambulacral pores very unequal, the internal rounded, the outer narrowed, oblique, elongate. Beyond the petals the pores are no longer visible, but reappear on the ventral side, though few and rare. Tubercles of small size, numerous, crowded, homogeneous. Periproct circular, nearer to the posterior border of the test than to the peristome, which is not preserved in the single known specimen.

The material in the U. S. National Museum consists of one quite complete specimen, evidently the original of Cotteau's figures, and a fragment, about one-half of a test. Cotteau says there is only one specimen, so this second one may have come in later. The complete specimen measures $3.25 \mathrm{~mm}$. in height, $13.5 \mathrm{~mm}$. in length, and $13 \mathrm{~mm}$. in width through ambulacra II and IV. These measurements are slightly greater than those given by Cotteau, but in a number of specimens measured I do not find that my measurements quite agree with his. The specimen does not show the genital and ocular pores, but a pit, dorsal to interambulacrum 2, appears to be the single madreporic pore which is characteristic of the genus.

Eocene, St. Bartholomew limestone, St. Bartholomew, Guppy collection ex Cleve, the holotype, the original of Cotteau's figures, and an additional fragmentary specimen, U. S. Nat. Mus. No. 115394.

\section{Sismondia anguillæ Cotteau.}

(Plate 2, Figures 8, 9.)

Sismondia anguilla Cotteau, 1875, Kongl. Sven. Vet. Akad. Handl., vol. 13, No. 6, p. 18, plate 3, figs. 5 to 8 .

Sismondia antillarum Brown, 1914 (non Cotteau), Proc. Acad. Nat. Sci., Philadelphia, vol. 65 , p. 601.

The following is an extract from the original description of this species:

Species of small size, rounded, slightly oval, a little angular anteriorly; upper face convex, lower face depressed, concave in the middle. Apex central. Ambulacral petals relatively large, subcostulate, open at their tips. Ambulacral pores very unequal, the inner ones rounded, the outer narrow, oblique, and very elongate. At some distance from the border of the test the pores cease to be petaloid, becoming equal, rounded, and disposed in oblique pairs. They are not visible on the lower side of the test. Tubercles are crowded, abundant, homogeneous. Periproct circular, situated about halfway from the peristome to the posterior border of the test, but a little nearer to the latter. Peristome rounded, opening in the middle of the lower face in a deep depression. 
The specimen measures $3.5 \mathrm{~mm}$. in height, $10.5 \mathrm{~mm}$. in length through ambulacrum III and interambulacrum 5, and $10 \mathrm{~mm}$. in width. The genital pores were made out above the interambulacra 2,3 , and 4 , but did not show in area 1 , where one doubtless existed. The genital pore is absent in area 5 as a typical character. The ambulacral pores on the ventral side are indicated in Cotteau's figure 7, but he states in the text that they are invisible on the lower side, and I could not perceive any trace of them. This species is easily distinguished from antillarum by its more elevated test and open petals.

Oligocene, Anguilla formation, island of Anguilla, Guppy collection ex Cleve, 1 specimen, the holotype, U.S. Nat. Mus. No. 115421. Antigua formation, Willoughby Bay, Antigua, A. P. Brown collector, 1913, 2 specimens, Philadelphia Acad. Nat. Sci. No. 1662.

\section{Family CLYPEASTRIDE A. Agassiz, 1873.}

Genus ANOMALANTHUS Bell, 1884 .

Anomalanthus Bell, 1884, Proc. Zoöl. Soc. London, p. 43, plates 2, 3.

Type species.-Echinanthus tumidus Tenison-Woods, 1878, Proc. Linn. Soc. N. S. W., vol. 2, p. 169.

This genus, Anomalanthus, is based on a Recent species from Australia, but of somewhat doubtful locality. This Recent species with the following are the only species so far attributed to the genus.

\section{Anomalanthus gregoryi Lambert.}

Anomalanthus gregoryi Lambert, 1915, Mém. Soc. d'Agric. de l'Aube (Troyes), vol. 79, p. 27, plate [unnumbered], figs. $1,2$.

The following is a description of this species:

Test large, ovoid, subhemispherical, $177 \mathrm{~mm}$. in length, $101 \mathrm{~mm}$. in width, and $57 \mathrm{~mm}$. in height. Apical disk slightly anterior. Ambulacral petals very long, widely flaring, ventrally moderately concave, peristome inframarginal.

As the petals, though very flaring, curve in slightly at the distal ends in $A$. gregoryi, also as the periproct is inframarginal, it is doubtful if the species should be referred to Anomalanthus. In the type of that genus the petals are flaring and straight throughout and the periproct is marginal, both of which characters distinguish Anomalanthus from Clypeaster. While gregoryi is very close to Anomalanthus, it seems to have characters of both the allied genera.

"Miocene," Antigua. Lambert says that the matrix differs from that of other "Miocene" [Oligocene] Echini of Antigua and indicates a different bed, J. W. Gregory collector, 1899, collection of British Museum. 


\section{Genus CLYPEASTER Lamarck, r8or.}

Type species.-Echinus rosaceus Linné, 1758,Syst. Nat., ed. 10, p. 665. The genus Clypeaster is represented by many species, 19 occurring fossil in the fauna of the West Indies. The species have so much variation, and the characters of different species run so close, that Doctor Clark's expert opinion in diagnosing them has been of the greatest value in describing the material and arriving at conclusions as to what should be considered as distinct species.

Many fossil species have been described by Cotteau and other authors from this region, but it has been found necessary to add 5 new ones to include material that could not find a place in those already described. On account of the closeness and difficulty of identifying species of Clypeaster, I have given under each species the essential diagnostic characters, even where there were no available specimens.

\section{Key to the West Indian Fossil Species of Clypeaster.}

1. Oral surface of the test deeply concave.

A. Poriferous areas of petals more or less incurved at tip, of ten nearly or quite closing petal; if petals are widely open, the interporiferous area is broadly obovate.

B. Petals more or less obovate; interporiferous area near proximal end only about half as wide as it is where widest.

C. Mouth and apical system approximately central.

$D$. Width of test 85 per cent of length, or less.

$E$. Test not excessively arched nor interporiferous areas remarkably swollen.

$F$. Petals more or less widely open................... rosaceus

$F F$. Petals more or less nearly closed.

$G$. Test with a more or less evident flat area, distal to petals; poriferous areas, especially of petals II and IV, rather markedly wider near tips, which bend in somewhat abruptly and nearly meet.... C. concavus

GG. Test more uniformly arched, with no flattened area distal to petals; poriferous areas not markedly widened near tips, which, after bending inwards, turn abruptly outwards and run parallel for a

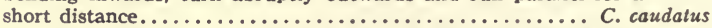

EE. Test excessively arched and interporiferous areas remarkably swollen.. C. dalli

$D D$. Width of test 90 per cent of length, or more............... cubensis

CC. Apical system distinctly excentric posteriorly, mouth perhaps posterior; petals very large, posterior pair reaching nearly to the ambitus.. $C$. parra

$B B$. Petals long, elliptical; interporiferous areas not twice as wide distally, or near middle as proximally.

H. Test narrow anteriorly, its width just in front of petals II and IV about 70 per cent of length; petaloid area small, its length about 60 per cent of test length; tips of petals II and IV nearly closed and rather abruptly so, as though pinched together........ lanceolatus

$H H$. Test in front of petals II and IV with width about 80 per cent of length; petaloid area large; with its length about 70 per cent of test length; tips of petals II and IV more or less widely open.. C. antillarum

$A A$. Poriferous areas of petals not strongly incurved at tip; petals widely open.

1. Petals rounded and poriferous areas incurved at tip, at least a little.

$\boldsymbol{J}$. Sides of interporiferous areas convex, converging slightly near tip.

$K$. Petals all marked with distinct furrows connecting the pores of a pair, test more or less arched; test margin moderately thin...... C. planipetalus

$K K$. Petals very indistinct, with furrows connecting pore-pairs shallow, or nearly wanting; test flat with very thick margin.......... cryplopetalus

$J$. Sides of interporiferous areas nearly or quite straight and even a little diverging in some cases...................................... cou

11. Petals truncate and poriferous areas more or less so.

L. Petaloid area two-thirds of test length .................. batheri

LL. Petaloid area distinctly more than two-thirds of test length......... C. parvus 
Key to West Indian Fossil Species of Clypeaster-Continued.

2. Oral surface of test slightly concave or flat, with mouth more or less sunken.

$M$. Test convex, sloping upward more or less uniformly from the thick margin.

$N$. Height of test equal to or exceeding one-half its width.......... duchassaingi

$N N$. Height of test not more than one-third its width ............... ambigenus

$M M$. Test flattened; if petaloid area is elevated, it does not slope upward evenly from margin.

$O$. Test with thin, uniformly sloping margin.

$P$. Test very flat, with flush petaloid area ................ placentoides

$P P$. Test not flat, its petaloid area conspicuously elevated......... . meridanensis

$O O$. Test with very thick, more or less swollen margins.

$Q$. Oral surface distinctly concave .................... oxybaphon

$Q Q$. Oral surface perfectly flat.......................... platygaster

\section{Clypeaster rosaceus (Linné).}

Echinus rosaceus Linné, 1758, Syst. Nat., ed. 10, p. 665.

Clypeaster rosaceus Lamarck, 1801, Anim. sans Vert., p. 349. Cotteau, 1897, Bol. Com. Mapa Geol. España, vol. 22, p. 29, plate 5, figs. 1 to 5. Lambert, 1915, Mém. Soc. d'Agric. de l'Aube (Troyes), vol. 79, p. 19.

\section{The following is a description of this species:}

This well-known living species, occurring abundantly in the Recent fauna of the West Indies, also occurs fossil in the same region. Test very large, pentagonal in outline, the sides and posterior end being somewhat concave, the anterior end bluntly pointed, and margin thick. The upper surface is convex, very variable in the height and width of the test, but Dr. H. L. Clark says he has never seen a specimen in which the width equaled 85 per cent of the length. The under surface is flat near the margin, but deeply concave to the peristomal opening. The ambulacral petals are very broad, usually strongly elevated. The interporiferous area is almost always markedly obovate, especially in the anterior petals II and IV. In the poriferous areas there are 6 to 9 primary tubercles on the ridges between the pore-pairs. The interambulacral areas are very narrow, especially at the margin. Apical disk is central, peristome pentagonal, central, at the bottom of the deep central cavity; periproct small on the ventral side, but near the posterior border of the test.

A very fine large specimen, collected by Mr. Mitchell in Porto Rico, gives the following measurements: height, $45 \mathrm{~mm}$.; length through ambulacrum III and interambulacrum 5, $132 \mathrm{~mm}$.; width, $107 \mathrm{~mm}$.

This species seems to be peculiar in its distribution as a fossil. It is quite abundant in Porto Rico and is reported by Cotteau from Cuba, but excepting Lambert's I do not know of definite records of fossil material from other islands of the West Indies. It is such a massive, solid species it should have been preserved if it had occurred.

Desor (1858, Synopsis des Échinides, p. 244) notes that rosaceus occurs fossil and says "Des Antilles et de la Guadeloupe. Très abondant." It seems that this has reference, however, to the abundance of the living form in that region rather than as a definite locality for the fossil. He gives the name Clypeaster incurvatus Desmoulins (which is a nomen nudum) as a synonym of $C$. rosaceus. 
Miocene (?), from a solid buff limestone along south coast of Porto Rico, about 5 miles west of Ponce, in what is called Culebrinas Point; this limestone is exposed in a bluff over 50 feet high; 3 fine specimens. Station 37/5, Graham John Mitchell collector, 1917. Mr. Mitchell had charge of the Ponce District in the Survey work of 1917. Ponce Chalk, Government Road, Ponce to Penuelas, km. 1, collected from embankment 200 feet long on north side of the road, Porto Rico, 1 fine specimen, station 285. Ponce limestone, cliff bank, north side of Ponce to Penuelas Road, km. 2, about $5 \mathrm{~km}$. west of Ponce, Porto Rico, 1 specimen, station 299. Same data, 2 specimens, station 301. Material from the Porto Rico stations 285, 299, and 301 collected by C. A. Reeds, on Expedition of the New York Academy of Sciences, the Porto Rican Government and the American Museum of Natural History coöperating.

The locality given by Cotteau is calcareous concretions, Bellamar, in the Province of Matanzas, Cuba. He does not give any geological horizon, but says the specimen he figured is in the collection of the Comisión del Mapa Geologico de España. Lambert reports this species from Anguilla and says the matrix is a calcareous tuff very different from that of the Miocene species and evidently is Pliocene; J. W. Gregory collector, 1899, specimen in the British Museum.

\section{Clypeaster concavus Cotteau.}

(Plate 2, Figures 10 to 12.)

Clypeaster ellipticus Guppy (non Michelin), 1866, Quart. Jour. Geol. Soc. London, vol. 22, p. 299.

Clypeaster concavus Cotteau, 1875, Kongl. Sven. Vet. Akad. Handl., vol. 13, No. 6, p. 16, plate 2, figs. 4 to 8. Guppy, 1882, Scientific Assoc. Trinidad, Proc., part 12, p. 195. Cotteau, 1897, Bol. Com. Mapa Geol. Espana, vol. 22, p. 36, plate 7, figs. 4 to 8 , Lambert, 1915, Mém. Soc. d'Agric. de l'Aube (Troyes), vol. 79, p. 18.

Echinanthus concavus Gregory, 1895, Quart. Jour. Geol. Soc. London, vol. 51, p. 295.

Diplothecanthus concavus Brown, 1914, Proc. Acad. Nat. Sci. Philadelphia, vol. 65, p. 600.

The following is an extract from the original description of this species:

Species of medium size, narrowed and rounded anteriorly, wider and subtruncate posteriorly, upper face more or less swollen, sometimes subconvex, always thinning posteriorly, ventral side strongly depressed. Apical disk nearly central. Ambulacral areas wide, swollen, strongly petaloid. Petals nearly closed at the tips, unequal, the anterior petal III being longer and narrower than the other four. Poriferous areas very much developed, having their greatest width toward the tips of the petals, formed of pores distinctly unequal, united by a groove. In the part where the poriferous areas are the widest, the ridges of the test which separate the grooves contain each a series of 10 or 12 small tubercles. Peristome narrow, subpentagonal, opening in the excavation of the lower side. Periproct small, rounded, near the posterior border of the test, from which it is separated by a narrow band of test. Apical disk stelliform, with 5 genital pores.

A large specimen in the U. S. National Museum, Cleve collection (No. 115375), measures $21.5 \mathrm{~mm}$. in height, $73 \mathrm{~mm}$. in length, and 58.5 
$\mathrm{mm}$. in width. A larger and very perfect specimen (No. 115376) from Anguilla measures $25 \mathrm{~mm}$. in height, $100 \mathrm{~mm}$. in length, and $84.5 \mathrm{~mm}$. in width. Clypeaster concavus is very near to $C$. rosaceus, but in the latter the petals are always well open, often very widely so, while the test is usually at least one-third as high as it is long. In concavus, however, the petals are nearly closed and the test is not one-third as high as it is long. There are small (young) specimens of rosaceus that are very close to concavus, which suggests a genetic connection between the species. Cotteau's figures show the petals in concavus more widely open and blunter than they are in the specimens. This species has been found at a number of localities in the West Indies and is represented by many specimens in the U. S. National Museum.

A small specimen of this species, collected at Arroyo Blanco, near Cevicos, Dominican Republic, by Messrs. Cooke and Ross, is of interest as being a four-rayed individual. There are 4 petals dorsally and, as far as can be made out, the specimen is completely four-rayed throughout (plate 2, fig. 12). This tetramerous variant falls under the system No. 4, in Jackson's study of tetramerous Echini (Phylogeny of the Echini, p. 38).

Oligocene, Anguilla formation, island of Anguilla, Guppy collection, 1 specimen, U. S. Nat. Mus. No. 115373. Anguilla, Guppy collection, 2 specimens, labeled $C$. ellipticus Mich.=concavus Cotteau, U. S. Nat. Mus. No. 115374. Anguilla, Guppy collection ex Cleve, cotype, labeled as original of Cotteau's plate 2, figures 4 to 8, U. S. Nat. Mus. No. 115375. Anguilla, Guppy collection ex Cleve, cotype, U. S. Nat. Mus. No. 115376. Cotteau mentions, besides the Cleve collection, having material from the museums of Stockholm and Upsala. Anguilla, Guppy collection, bearing the original label $C$. ellipticus and on the reverse C. concavus, U. S. Nat. Mus. No. 115377.

Oligocene, Anguilla formation, Crocus Bay, roadside descent to Crocus Bay from Valley, Anguilla, T. W. Vaughan collector, 1914, 1 specimen, U.S. Geol. Sur. station 6893. Crocus Bay Bluff, southwest side, 125 feet above sea-level, Anguilla, T. W. Vaughan collector, 1914, 2 specimens, U. S. Geol. Sur. station 6967. Anguilla, several specimens, British Museum, reported on by Lambert. Arroyo Blanco, Cevicos limestone, near Cevicos, Dominican Republic, Cooke and Ross collectors, 1 four-rayed specimen, U. S. Nat. Mus. No. 328233, and 4 fragments, U.S. Geol. Sur. station 8598. Jique de la Argolla, Rio Seco de San Antonio, Guantanamo, Cuba, C. T. Ramsden collection, 1 young specimen. Limestone escarpment northwest of Utuado, Porto Rico, Arecibo formation, H. E. Anthony collector, 2 specimens, station 554, Expedition of New York Academy of Sciences, the Porto Rican Government and American Museum of Natural History coöperating.

Gregory reports having this species from Antigua. Dr. A. P. 
Brown says that $C$. concavus is the commonest echinoid in the Antigua white limestone (Antigua formation) and was found in great numbers at Hodges Bay, Antigua (4 specimens in Philadelphia Acad. Nat. Sci., No. 1658); along the shore at Willoughby Bay, Antigua (9 specimens, Philadelphia Acad. Nat. Sci., No. 1659); and at High Point, Antigua. Oligocene, Havana, Cuba, from de la Torre collection, 1 specimen, Mus. Comp. Zoöl. No. 3233. Cotteau, in his Spanish report, gives the horizon as "Miocene" and the localities, Province of Santa Clara, also ingenios San Marco and San Lino and Cienfuegos, Cuba, collection of Comisión del Mapa Geológico de España, Madrid.

\section{Clypeaster caudatus, new species.}

(Plate 3, Figures 1, 2.)

The following is a description of this species:

This species, while near to others, has features which distinguish it from rosaceus and concavus. The test is massive, quite uniformly arched, but with rather a gradual slope from the apical disk to the anterior border of the test, and posteriorly a less marked slope to the rather abruptly truncated posterior border. The outline of the test is rounded anteriorly; posteriorly it is abruptly rounded and truncated, even slightly reëntrant on the median line. The ambulacral petals are very broad and long, nearly closed at the tips and pinched up so that the interporiferous area at the end of the petal terminates in a tail-like tip, especially in ambulacra I, V and II, IV. The anterior petal III is longer than the anterior pair II and IV and is of the same length as the posterior pair I and V. The anterior petal III at its broadest part has the same width as petals II and IV, but is distinctly narrower than petals I and V. The interporiferous areas of the petals are wide and only very slightly raised above the general outline of the test. The apical disk is nearly central and the $\mathbf{5}$ genital pores are clearly shown in the holotype. As the ventral side of the test is hidden in both specimens, no observations can be made on the peristome, periproct, or other ventral characters. Both specimens are so worn that the tubercles are largely eroded away, but dorsally where visible they are numerous and closely associated. Ventrally the tubercles are somewhat larger and very densely crowded, so that there is almost no intertubercular tissue.

The holotype measures about $45 \mathrm{~mm}$. in height, $141 \mathrm{~mm}$. in length and $121 \mathrm{~mm}$. in width. A smaller specimen, the paratype, measures $25 \mathrm{~mm}$. in height, $80 \mathrm{~mm}$. in length, and $70 \mathrm{~mm}$. in width. Clypeaster caudatus is very near to $C$. concavus; the small specimen differs only in the more markedly arched test and in the fact that the tips of the petals are pinched together and pulled out distally.

Miocene, Gurabo formation, or the Mao Adentro limestone, Rio Gurabo, near Los Quemados, not in place, probably from Zone C, Dominican Republic, Dr. C. J. Maury collector, 1907, holotype, U. S. Nat. Mus. No. 328235. Paratype with same locality and data, U. S. Nat. Mus. No. 328236. 


\author{
Clypeaster dalli (Twitchell). \\ (Plate 4, Figure 1.)
}

Diplothecanthus ${ }^{1}$ dalli Twitchell, in Clark and Twitchell, 1915, Monograph U. S. Geol. Survey, vol. 54 , p. 218 , plate 99 , figs. $2 a, b$; plate 100 , figs. $1 a, b$.

The following is an extract from the original description of this species:

Test large, pentagonal in outline, longer than broad, widest across the line of ambulacral petals II and IV; pointed anteriorly, posterior end truncated; upper surface irregularly convex, high, highest back of the center, thence sloping in a straight line to the blunt tumid anterior edge, and quite steeply and in a straight line to the thinner wedge-shaped posterior edge; the under surface deeply concave. Ambulacral petals large, broad, very tumid, almost reaching to the margin, nearly closing distally; the posterior pair slightly longer than the odd anterior petal, which is slightly longer than the anterior pair. Apical system central, sloping downward anteriorly; 5 genital pores a slight distance from the slightly depressed madreporite. Peristome large, a little excentric posteriorly, subpentagonal, deeply sunken; ambulacral furrows simple, straight, reaching the margin. Periproct rather large, subcircular, inframarginal.

The specimen in hand, from the Dominican Republic, measures $60 \mathrm{~mm}$. in height, $125 \mathrm{~mm}$. in length, and $108 \mathrm{~mm}$. in width across the line of ambulacra II and IV. The height is not far from half the length of the test, the same feature being indicated by Twitchell's measurements of his type material. Clypeaster dalli is a well-marked species on account of its highly swollen petaloid areas, but it is to be remarked that some specimens of $C$. rosaceus are noticeably swollen. This seems to be just one of those cases in which, among nearly related species, the individual variant of one species takes on the character typical of an allied species. This species was described by Twitchell from the Pliocene, near Fort Thompson, Caloosahatchee River, Florida. The type material, collected by Dr. William H. Dall, is in the U. S. National Museum, No. 164670.

Miocene or Pliocene, Gato, on the southern side of the island, Dominican Republic, given to Dr. Carlotta J. Maury by the late Señor Rodolfo Cambiarso, of Santo Domingo; Miss Maury very kindly gave it to the National Museum, U. S. Nat. Mus. No. 328234.

\title{
Clypeaster cubensis Cotteau.
}

Clypeaster cubensis Cotteau, 1875, Kongl. Sven. Vet. Akad. Handl., vol. 13, No. 6, p. 6.; 1881, Ann. Soc. Géol. de Belgique, vol. 9, p. 16; 1897, Bol. Com. Mapa Geol. España, vol. 22, p. 33, plate 6, figs. 1 to 5 .

This species, of which no material has been available, seems to be valid, as it is remarkably wide in proportion to its length and has very large petals.

Miocene (?), Matanzas, Cuba, collections of Cotteau in Paris and of Comisión del Mapa Geólogico de España, in Madrid.

${ }^{1}$ Dr. Hubert Lyman Clark (The Genera of Recent Clypeastroids, 1911, Ann. Mag. Nat. Hist., ser. 8 , vol. 7 , p. 600) does not recognize Duncan's Diplothecanthus as a distinct genus. 


\section{Clypeaster parræ Desmoulins.}

Erizos petrificados Antonio Parra, 1787, Descripción de diferentes piezas de Hist. Nat. del ramo maritimo, Havana [Cuba], p. 181, plate 65 , fig. 2.

Clypeaster parra Desmoulins, 1835-37, Etud. sur les Echin., pp. 218 to 219. Michelin, 1861, Monog. des Clyp. fossiles, Mém. de la Soc. Géol. de France, vol. 7, p. 112, plate

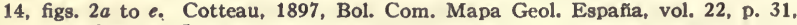
plate 11 , figs. 1 to 5 .

This species, of which I have not seen material, is well marked by the excentric position posteriorly of the apical system and the excessively large petals. Cotteau says that neither the mouth nor periproct was preserved in the specimen from which Michelin described the species. The mouth (in a posterior position) and periproct are indicated in Cotteau's cross-section, plate 11, figure 2 , but in view of his statement, this figure must be considered schematic.

According to Michelin, this species is found in the Tertiary and littoral formations of the islands of Cuba and Guadeloupe, Michelin collection.

\section{Clypeaster lanceolatus Cotteau.}

(Plate 4, Figure 2.)

Clypeaster lanceolatus Cotteau, 1897, Bol. Com. Mapa Geol. España, vol. 22, p. 39, plate 9. figs. 1 to 3. Lambert, 1915, Mém. Soc. d'Agric. de l'Aube (Troyes), vol. 79, p. 24. Jackson, 1917, Proc. U. S. Nat. Mus., vol. 53, p. 490, plate 62, figs. 1, 2; 1919 , Bull. 103, U. S. Nat. Mus., p. 104, plate 46, figs. 1 to 2.

The following is an extract from the original description of this species:

Test oval, upper face moderately elevated, lower face concave; the 5 ambulacral furrows are well marked from the peristome to the border. Ambulacral areas are petaloid, slightly elevated, lanceolate, almost closed at the tips. Poriferous areas are narrow, depressed, terminating in a closed point, each of the plates bearing 5 or 6 tubercles. Peristome subpentagonal. Periproct circular, distinctly near the border of the test. Vertex central. Apical disk not visible, as the test is worn away at that point.

The specimen in the American Museum measures about $25 \mathrm{~mm}$. in height; the length is doubtful, as it is broken away posteriorly, but it would, as estimated, measure about $120 \mathrm{~mm}$. in length and $98 \mathrm{~mm}$. in width. Cotteau gives as the measurements of his type specimen, height, $21.5 \mathrm{~mm}$.; length, $86 \mathrm{~mm}$.; width, $65 \mathrm{~mm}$. (?). The width in his measurements is queried, as the specimen is incomplete on one side. The New York Museum specimen is therefore distinctly larger than the type, but seems to be clearly referable to this species. Clypeaster lanceolatus is near to $C$. antillarum, but it has a relatively smaller petaloid area, more elevated petals, and is more deeply concave ventrally than is antillarum.

This species is credited to Azpeita by Cotteau, but it is a purely manuscript name with Azpeita and should be credited to Cotteau, who first published it.

Oligocene, Havana, Cuba, not far from the university buildings; 1 specimen, collected by Barnum Brown, American Museum Natural 
History, No. 18577. Cotteau gives his type as from the "Miocene," Matanzas, Cuba, very rare; collection of Comisión del Mapa Geológico de España. Lambert reports specimens from the "Miocene" of Antigua, collected by J. W. Gregory, 1899, collection of British Museum. It is of interest that this species, as described by Jackson, occurs in the Oligocene, Emperador limestone, of Las Cascadas, Panama, U. S. Nat. Mus. No. 324452; also at a nearby locality opposite Las Cascadas, Gaillard Cut, U. S. Nat. Mus. No. 324451.

\section{Clypeaster antillarum Cotteau.}

(Plate 5, Figures 1, 2.)

Clypeaster antillarum Cotteau, 1875, Kongl. Sven. Vet. Akad. Handl., vol. 13, No. 6, p. 15, plate 2, figs. 1 to 3. Guppy, 1882, Scientific Assoc. Trinidad, Proc., part 12, p. 195. Cotteau, 1897, Bol. Com. Mapa, Geol. España, vol. 22, p. 35, plate 7, figs. 1 to 3. Lambert, 1915, Mém. Soc. d'Agric. de l'Aube (Troyes), vol. 79, p. 25.

Echinanthus antillarum Gregory, 1895, Quart. Jour. Geol. Soc. London, vol. 51, p. 295 . Non Cotteau, see p. 56.

Diplothecanthus antillarum Brown, 1914, Proc. Acad. Nat. Sci., Philadelphia, vol. 65, p. 601.

The following is an extract from the original description of this species:

Species of large size, subpentagonal, a little angular anteriorly, truncated squarely posteriorly; upper face moderately swollen, thick and subsinuous on the border; lower face nearly flat in the inframarginal region, strongly concave in the middle, marked with 5 ambulacral grooves, which are pronounced at some distance from the border and descend in to the peristome. Apical disk subcentral, a little posterior to the center. Ambulacra swollen, strongly petaloid, scarcely open at their extremities, unequal, the anterior ambulacrum longer and narrower than the others; poriferous areas very wide, with pores rounded, united by a groove; interporiferous areas relatively little developed. Peristome subpentagonal, deeply sunken. Periproct small, near the border, subelliptical in the transverse diameter.

One splendid specimen in the National Museum measures $33.5 \mathrm{~mm}$. in height, $123 \mathrm{~mm}$. in length, and $112 \mathrm{~mm}$. in greatest width across ambulacra II and IV. This species is undoubtedly near to rosaceus, but the form of the interporiferous areas is entirely different. Besides the type in the Cleve collection, 2 fine specimens from Cuba in the American Museum are ascribed to this species.

Oligocene, Anguilla formation, island of Anguilla, Guppy collection ex Cleve, holotype, U. S. Nat. Mus. No. 115390. Disintegrated limestone near asylum in quarry near Guajay, 15 miles southwest of Havana, Cuba, 2 specimens, American Museum of Natural History, No. 18578. Consolación del Sur, Province of Pinar del Rio, Cuba, collected by the alcalde, 1901, U. S. Geol. Sur. station 3474. Gregory reports this species from Antigua in 1895, it, with $C$. concavus, he says, being the most typical species of the West Indian Oligocene. Dr. A. P. Brown collected a specimen which he identified as antillarum in the Antigua formation at Willoughby Bay, Antigua; it is rather indistinctly preserved and is in the Philadelphia Academy Natural Sciences, No. 1660. Lambert tentatively refers to this species a rather imper- 
fect specimen from the "Miocene" of Antigua, collected by J. W. Gregory in 1899, collection of British Museum. Cotteau ascribes the species to the "Miocene" and gives the locality as San Martin, Province of Matanzas, Cuba.

\section{Clypeaster planipetalus Cotteau.}

(Plate 6, Figures 1, 2.)

Clypeaster planipetalus Cotteau, 1897, Bol. Com. Mapa Geol. Espa ña, vol. 22, p. 38, plate 8 , figs. 1 to 4.

The following is an extract from the original description of this species:

Test medium-sized, elliptically subpentagonal, truncate posteriorly, elongate anteriorly. Upper side moderately elevated, lower side moderately concave. Ambulacral areas petaloid, open at the distal ends. Poriferous areas with round pores united by shallow furrows. At the distal ends of each poriferous area the internal pores are almost united with the external, coming together in an irregular manner. On each of the ridges which separate the ambulacral furrows is a band of tubercles, 4 or 5 in number, on the outer broad part of each area. Tubercles small, abundant, somewhat larger on the lower side, showing between them fine granulation. Madreporic plate decagonal in form, porous, bulky, including almost the whole of the apical disk. The 5 genital pores, rather large, appear on the border of the madreporite. The ocular plates, somewhat triangular, show a little pore on their outer border. Peristome invisible in the specimen described. Periproct small, a little separated from the margin.

There is quite a series of specimens of this species from Antigua. The best-preserved one, which is figured, measures $88 \mathrm{~mm}$. in length, $78 \mathrm{~mm}$. in width, and about $30 \mathrm{~mm}$. in height. This specimen is proportionately much wider than typical. The apical disk is a little anterior to the center of the test, as it is also in Cotteau's figure, although he does not mention it in his text. This specimen has 6 tubercles on the ridges between the ambulacral furrows instead of 4 or 5 as described in the type, but other specimens show fewer than 6 .

Oligocene, Antigua formation, from bluff on north side of Willoughby Bay, Antigua, T. W. Vaughan collector, 1 figured specimen, U. S. Nat. Mus. No. 328237. Also, with same data, 8 specimens, U.S. Geol. Sur. station 6881, U. S. Nat. Mus. No. 328238. Cotteau records this species from the "Miocene" of ingenio San Lino, Province of Santa Clara, very rare, collection of Comisión del Mapa Geólogico de España.

\section{Clypeaster cryptopetalus, new species.}

(Plate 6, Figures 3 to 5.)

The following is a description of this species:

Test rather small, elongate, subpentagonal, thick on the margins, flattened above, moderately concave below. Much longer than wide. The specimens, excepting one, are not at all compressed or worn, being in excellent condition of preservation, so that the shape and characters can not be ascribed to wear. The ambulacral petals are almost perfectly flush with the surface and are extraordinarily inconspicuous. This is due to the 
flushness and the shallowness of the pore-pair furrows. Petals open at the tips. Apical disk in the center of the test. The peristome doubtless is central in position, but is not visible. Tubercles are well preserved, rather scattered dorsally, closely associated ventrally. Periproct small, situated on the ventral side, $3 \mathrm{~mm}$. from the posterior border of the test.

The holotype measures $21 \mathrm{~mm}$. in height, $68 \mathrm{~mm}$. in length, and $58 \mathrm{~mm}$. in width in the plane of ambulacra II and IV, which is the widest part of the test. The petals of ambulacra II, III, and IV give closely the same measurements, namely, $21 \mathrm{~mm}$. long by $12 \mathrm{~mm}$. wide at the widest part; petal $\mathrm{I}$ is in part hidden, but petal V, the left posterior, measures $27 \mathrm{~mm}$. in length by $13 \mathrm{~mm}$. in width.

This species is readily distinguished by its flattened, biscuit-like form and the almost invisible character of the petals.

Oligocene, Antigua formation, Rifle Butts, Antigua, T. W. Vaughan collector, February 1914, 3 specimens, all very well preserved, U. S. Geol. Sur. station 6854; the holotype, U. S. Nat. Mus. No. 328239, and 2 paratypes, U. S. Nat. Mus. No. 328240. Base and western slope of Friar's Hill, Antigua, T. W. Vaughan collector, February 1914, 1 specimen, much worn, U. S. Geol. Sur. station 6856. The stratigraphic position of the horizon at which these specimens were collected is near the bottom of the Antigua formation.

\section{Clypeaster cotteaui Egozcue.}

(Plate 6, Figures 6 to 8.)

Clypeaster cotteaui Egozcue in Cotteau, 1897, Bol. Com. Mapa Geol. Espafia, vol. 22, p. 40, plate 10, figs. 1 to 4 . Lambert, 1915, Mém. Soc. d'Agric. de l'Aube (Troyes), vol. 79 , p. 24.

The following is an extract from the original description of this species:

Test of moderate size, oval, a little narrowed anteriorly, upper surface slightly convex. Margin thick and rounded. Lower surface concave, with ambulacral furrows which expand and deepen as they approach the mouth. Peristome pentagonal. Periproct circular, slightly separated from the margin. Apex nearly central, very little excentric anteriorly. Apical disk small, with madreporite constituting a relatively large star. Ambulacral areas superficial, petals truncate and very open at the distal tips. Poriferous areas a little depressed and very characteristic, the inner series of pores curving and converging near the apex of each ambulacrum, below which they make a nearly straight line to the distal tips, but converging. The outer series of pores curve throughout their whole length, forming in the extreme tip a curve of less radius, converging to meet the inner series; as a sort of termination, 4 pores, smaller and elongated, form an irregular quadrilateral. Each poriferous plate has 6 tubercles.

The specimen figured measures $20 \mathrm{~mm}$. in height, $65 \mathrm{~mm}$. in length, and $52 \mathrm{~mm}$. in width in the line of ambulacra II and IV. The ambulacral petals I, V, and III measure $22 \mathrm{~mm}$. in length and ambulacral petals II and IV measure somewhat less, $18 \mathrm{~mm}$. in length. Petals I and V measure $14 \mathrm{~mm}$. in width, but petals II, III, and IV are somewhat narrower, measuring only $12 \mathrm{~mm}$. in width. The periproct is 3 $\mathrm{mm}$. from the posterior border of the test. 
This species is markedly peculiar in its very widely open petals, the nearly straight line of the inner rows of pores, and the 4 pores situated below the tips of the petals. In the photographic figure these peculiar pores are seen well below the posterior pair of petals I and V.

Oligocene, from place of Marco Sanchez, at the base of Monte Toro, northwest of Guantanamo, Cuba, C. T. Ramsden's collection. Jamaica, 1 specimen, purchased of Ward, Mus. Comp. Zoöl. No. 3255. Cotteau gives as rare in the "Miocene" of Matanzas, Cuba, collection Comision del Mapa Geológico de España. Lambert reports a single badly distorted specimen from Antigua, collected by J. W. Gregory in 1899, collection of British Museum.

\section{Clypeaster batheri Lambert.}

Clypeaster batheri Lambert, 1915, Mém. Soc. d'Agric. de l'Aube (Troyes), vol. 79, p. 26, plate [unnumbered], figs. 3 to 7 .

The following is a description of this species:

Species of medium size, longer than wide, depressed, oval, narrowed anteriorly, subtruncate posteriorly. Upper face moderately convex, ventrally widely and deeply concave. Petals wide open, with a tendency to narrow toward the extremities. The type measures $52 \mathrm{~mm}$. in length, $44 \mathrm{~mm}$. in width, and $15 \mathrm{~mm}$. in height.

Lambert compares this species with $C$. cotteaui, from which he distinguishes it by its form more elongate, its petals longer and less open, and pores more widely spaced. It differs also in that cotteaui is high and rounded on the margin, whereas batheri is low on the margin. It differs from $C$. parvus in that the petals are proportionately very much longer in that species.

Lambert refers this species to the "Miocene" [Oligocene] of Antigua, collected by J. W. Gregory in 1899, collection of British Museum.

\section{Clypeaster parvus Michelin.}

Clypeaster parvus Michelin, 1861, Mon. Clyp. Foss., p. 117, plate 19, figs. $2 a$ to $f$. Cotteau, 1897. Bol. Com. Mapa Geol. España, vol. 22, p. 41, plate 15, figs. 1 to 3 . Lambert, 1915, Mém. Soc. d'Agric. de l'Aube (Troyes), vol. 79, p. 23.

Cotteau in his synonymy refers this species to Duchassaing 1847, Agassiz 1847, and Desor 1858; but. in these several references the name is a nomen nudum, as there is no adequate description. Michelin is clearly the first describer of the species. I have not seen any specimens of this species and it may only represent the young of $C$. cotteaui or $C$. planipetalus, but the very truncate petals and poriferous areas indicate that it is distinct. In the Revision of Echini, Mr. Agassiz considers parvus a synonym of rosaceus, presumably thinking it the young of that species, but comparison with young rosaceus (12 to $30 \mathrm{~mm}$.) shows that this is not the case, the petals being perfectly distinctive.

Cotteau says that it occurs in the white littoral tuff of Guadeloupe, 
where it is not rare; also in the vicinity of Havana, Cuba, where it is rare, collection of Comisión del Mapa Geológico de España. Lambert reports a single badly preserved specimen from Antigua, which from its association with Clypeaster lanceolatus and Echinolampas lycopersicus he attributes to the "Miocene" [Oligocene], collected by J. W. Gregory in 1899, collection British Museum.

Clypeaster duchassaingi Michelin.

Clypeaster duchassaingi Michelin, 1861, Mém. Soc. Géol. de France, ser. 2, vol. 7, p. 107, plate 9 , figs. $a$ to $g$.

Test convex, sloping upwards from its thick margin, differs from $C$. rosaceus and ellipticus by its flat base and petals not swollen.

Michelin gives as "formations madréporiques," Guadeloupe, Antilles.

$$
\text { Clypeaster ambigenus (Lamarck). }
$$

Scutella ambigena Lamarck, 1816, Anim. sans Vert., vol. 3, p. 12.

Clypeaster ambigenus Blainville, 1834, Manuel d'Actinolgie, p. 216. Michelin, 1861, Mém. Soc. Géol. de France, ser. 2, vol. 7, p. 113, plate 15, figs. $1 a$ to $f$.

The following is a description of this species:

Test low, rounded, flattened on base. Differs from rosaceus by its flattened base and large tubercles around the peristome.

Michelin says: "formations modernes et madréporiques," Guadeloupe. He says it also occurs in the "Eocene" of Jacksonboro, Georgia.

Clypeaster placentoides, new species.

(Plate 7, Figures 1, 2.)

The following is a description of this species:

This species is represented by 2 individuals, a larger and a smaller, the latter resting on the dorsal face of the larger, as shown in the figures. The test is ovally rounded, a little longer than wide, thin, biscuit-like in shape, being very much flattened dorsally. The margin is relatively thin and the ventral side as far as shown on the larger specimen is very flat. The apical disk is central in position, but no details of structure are preserved. Ambulacral petals are nearly flush with the surface, rounded and moderately open at the distal ends. Poriferous areas sunken, the inner and outer rows of pores curved in outline. Furrows connecting the pores are moderately deep, with 3 or 4 tubercles on the intermediate ridges. Tubercles are small dorsally, larger and more densely associated on the ventral side. Periproct round, very near the posterior border of the test, as shown well on the larger specimen.

The larger specimen (on which the smaller rests, as seen in Plate 7, figs. 1, 2) measures $75 \mathrm{~mm}$. in length, $65 \mathrm{~mm}$. in width, and about $14 \mathrm{~mm}$. in height. The periproct is only $1.5 \mathrm{~mm}$. from the posterior border of the test. This larger specimen shows something of the flatness of the lower side and tubercles on the same, but does not show the peristome or ambulacral furrows which are hidden by the matrix. The smaller specimen measures $54 \mathrm{~mm}$. in length, $48 \mathrm{~mm}$. in width, and 
about $7 \mathrm{~mm}$. in height. The ambulacral petals are visible on this smaller specimen only. Petals I, V, and III measure $14 \mathrm{~mm}$. in length by $8 \mathrm{~mm}$. in width. Petals II and IV measure $12 \mathrm{~mm}$. in length by $8 \mathrm{~mm}$. in width.

Clypeaster placentoides is near to the Recent West Indian C. depressus in some particulars, but the petals are rounded at the tips, not bluntly pointed as in subdepressus. Also, the petals are flat, not markedly arched. The test is much thicker at the edge than in a specimen of subdepressus of the same size.

Oligocene, El Jique de la Argolla, about 2 miles from San Antonio Central, northeast of Guantanamo, Cuba, C. T. Ramsden's collection.

\section{Clypeaster meridanensis Michelin.}

Clypeaster meridanensis Michelin, 1850, Revue et Mag. Zoöl., vol. 2, p. 240; Mém. Soc. Géol. de France, ser. 2, vol. 7, p. 136, plate 14, figs. $1 a$ to f. A. Agassiz, 1883, Mém. Mus. Comp. Zoöl., vol. 10, No. 1, p. 89.

Test elevated dorsally, but very flat on base.

Michelin gives only Tertiary in the environs of Merida, Yucatan. A. Agassiz, however, records the species as "Miocene," Guadeloupe.

Clypeaster oxybaphon, ${ }^{1}$ new species.

(Plate 7, Figures 3, 4; Plate 8, Figures 1 to 3.)

The following is a description of this species:

Test low, pentagonal in outline, elongate anteriorly, truncate posteriorly; thick and rounded on the margin, depressed in a dish-like fashion dorsally, and in the center of the dish the proximal portion of the petals with the apical disk rise in a slight eminence, moderately concave ventrally. Ambulacral petals slightly raised above the general surface of the test; petals gently rounded, but open at the distal tips. Poriferous areas are sunken; the pores are connected by well-marked furrows, the ridges between which bear 8 or 9 small tubercles. The outline of both the inner and outer poriferous areas present a gentle curve from the base to the distal end. Petals I, V, and III are closely of the same length and width; II and IV are shorter, but of about the same width as the others. The apical disk is central in position, genital pores are large and sunken. Periproct well removed from the posterior border of the test. Ambulacral grooves are strongly marked, deepening toward the centrally placed mouth. Tubercles are small, closely associated, and somewhat larger and more crowded on the ventral side.

The holotype measures $116 \mathrm{~mm}$. in length, $102 \mathrm{~mm}$. in width across ambulacra II and IV, and about $17 \mathrm{~mm}$. in height. Another and more elongate specimen from Porto Rico measures $130 \mathrm{~mm}$. in length, $91 \mathrm{~mm}$. in width, and $24 \mathrm{~mm}$. in height. In this specimen the periproct is $4 \mathrm{~mm}$. from the posterior border of the test.

Clypeaster oxybaphon is very different from any other Recent or 
fossil West Indian Clypeaster, approaching nearest to $C$. platygaster, the next-described species, but it differs from that in that platygaster is perfectly flat ventrally, whereas oxybaphon is concave. C. oxybaphon resembles $C$. reticulatus (Linnæus) of the Indo-Pacific region in test form, but has very different petals.

Oligocene, Antigua formation, from bluff north side of Willoughby Bay, Antigua, T. W. Vaughan collector, 1914; U. S. Geol. Sur. station 6881, 4 specimens; the holotype, U. S. Nat. Mus. No. 328241; the paratype figured in plate 8, U. S. Nat. Mus. No. 328242; and two additional paratypes, U.S. Nat. Mus. No. 328243. Rifle Butts, Antigua, T. W. Vaughan collector, 1 specimen, U.S. Geol. Sur. station 6851.

Oligocene, cliff face, east shore Guanica Harbor, Porto Rico, 300 feet south of small cave (of station 341), beds of shaly limestone somewhat stratified; 8 good specimens, including those figured on plate 7, figures 3 and 4, which are in the American Museum Nat. Hist. Nos. 18567 and 18568; also some 50 fragmentary specimens, numerous stations under this locality, stations $368,369,371$ to $375,377,380$. East shore of Guanica Harbor, Porto Rico, from small cave in Tertiary limestone, $\operatorname{dip} 3^{\circ} 10^{\prime}$ south, 4 specimens, stations $341,345,346$. White gray ledge, capping top of hill, $1 \mathrm{~km}$. distant and south $37^{\circ}$ east of Guanica central mill, Porto Rico, 1 good specimen and 8 fragments, stations 355, 356. Juana Diaz shales, ford on Jacaguas River, $1 \mathrm{~km}$. northwest of Juana Diaz, Porto Rico, 4 fragments, station 185. All above Porto Rican material collected by C. A. Reeds on Expedition of the New York Academy of Sciences, the Porto Rican Government and American Museum of Natural History coöperating.

\section{Clypeaster platygaster, ${ }^{1}$ new species.}

(Plate 9, Figures 1, 2.)

The following is a description of this species:

Test elongate, pentagonal, drawn out anteriorly; truncate posteriorly, with thick, rounded margin. Dorsally the test is depressed in a saucerlike fashion, in the middle of which the center of the test rises to a moderate elevation above the outline of the thickened margin. Ventrally the test is perfectly flat, a marked distinction from the preceding species, C. oxybaphon. The apical disk, which is very small, does not show structural detail. It is situated almost in the center of the test, but about $3 \mathrm{~mm}$. nearer to the anterior border than it is to the posterior. Ambulacral petals are very broad, moderately elevated above the general surface, nearly closed at the tips. The petals are all of very nearly the same width, but III is the longest. The posterior pair I and V are shorter and the anterior pair II and IV are still shorter. The poriferous areas of the petals are very wide, sunken, and strongly marked; the furrows connecting the pores are deeply incised, and the ridges between bear about 10 small tubercles at the widest part. The interporiferous areas are remarkably attenuated. The ambulacral furrows on the ventral side are strongly marked, deepening 
to the peristomal border. The peristome is round, excentric, being $8 \mathrm{~mm}$. nearer to the anterior than to the posterior border of the test. Periproct on the ventral side is situated $5 \mathrm{~mm}$. from the posterior border of the test. The tubercles are small, widely spaced on the dorsal side, somewhat larger and more crowded on the ventral side.

This species is known only from the holotype, which is a beautifully preserved specimen. It measures $22 \mathrm{~mm}$. in height, $108 \mathrm{~mm}$. in length, and $84 \mathrm{~mm}$. in width across ambulacra II and IV, which is the widest part of the test. The ambulacral petal III measures $40 \mathrm{~mm}$. in length; petals I and V measure $37 \mathrm{~mm}$. and petals II and IV measure $30 \mathrm{~mm}$. in length; they all measure $18 \mathrm{~mm}$. in width at the widest part.

Clypeaster platygaster is well characterized as a species by the exceptionally flat ventral surface, the nearly closed petals with very broad poriferous areas, and the remarkable attenuated interporiferous areas. Another marked distinction of the species is the deeply depressed dorsal area surrounding the only slightly elevated central part of the abactinal surface.

This species bears considerable resemblance to $C$. oxybaphon, but differs in the relative size and shape of the petals, and differs markedly in that platygaster is perfectly flat ventrally, while oxybaphon is concave. Clypeaster platygaster also resembles Laganum elongatum, but in $C$. platygaster the petals are not sharply pointed distally, the poriferous areas are very much wider, and the test is flat ventrally. In Laganum elongatum, on the other hand, the petals are sharply pointed distally, the poriferous areas of the petals are narrow, and the test is concave around the peristome.

Oligocene, Havana, Cuba, not far from the university buildings; the holotype and only known specimen, collected by Barnum Brown, American Museum of Natural History, No. 18569.

Family LAGANID $\&$ Desor, 1857.

Genus LAGANUM Gray, 1825 .

Type species.-Echinodiscus laganum Leske, 1778, Add. ad Klein, p. 140.

The genus Laganum among Recent species is an Indo-Pacific type in its distribution, but fossil species have been referred to the genus from Europe and North America as well as the Far East. It is interesting that a West Indian fossil species has been described. The resemblance of Laganum to Clypeaster is very marked, but the test in Laganum is very flat, never highly arched. The petals are pointed at the tips and the auricles are fused into one piece, whereas in Clypeaster the test is more or less high and usually arched, the petals are rounded at the tips, and the auricles which give attachment to lantern muscles are separated, not fused. Laganum also closely resembles Peronella, but Laganum has 5 genital pores, or in one Recent species 6 genital 
pores, whereas Peronella has only 4 genital pores, the pore being absent in area 5.

Laganum elongatum Egozcue.

Laganum elongatum Egozcue, in Cotteau, 1897, Bol. Com. Mapa Geol. España, vol. 22, p. 26 , plate 4 , figs. 1 to 4 .

I have not seen a specimen of Laganum elongatum. It is a relatively large species; Cotteau says $16 \mathrm{~mm}$. in height, $74 \mathrm{~mm}$. in length, and $55 \mathrm{~mm}$. in width. It is flat, but high and rounded on the borders. Ventrally it is flat near the border, but deeply hollowed around the peristome. The ambulacral petals are narrow, acuminately pointed, with narrow poriferous areas. The apical disk is not known in the species, but it is assumed that it had 5 genital pores. If 4 only existed, then it would be referred to Peronella instead of Laganum.

Cotteau refers the single specimen described to the "Miocene," from the environs of Matanzas, Cuba, collection of Comisión del Mapa Geológico de España, Madrid.

Genus PERONELLA Gray, 1855 .

Type species.-Laganum peronii Agassiz, 1841, Monographies d'Echinodermes, Scutelles, p. 123.

The genus Peronella as well as Laganum among Recent species is an Indo-Pacific type in its distribution. It is therefore very interesting to find the genus represented fossil in the West Indies. It may be pointed out that of the 6 species referred to Laganum in Clark and Twitchell's memoir (1915, Mon. U. S. Geol. Sur., vol. 54), each is described as having 4 genital pores and might therefore be properly referred to Peronella rather than Laganum.

\section{Peronella mirabilis, new species.}

(Plate 9, Figure 3.)

The following is a description of this species:

Test small, thin, elongate, subpentagonal in outline, dorsally slightly elevated, with rounded low margin, flat ventrally. Ambulacral petals are narrow, pointed, but open slightly at the tips. Petals I, V, and III are of the same length, $6 \mathrm{~mm}$.; petals II and IV are a little shorter, $5 \mathrm{~mm}$. in length. Poriferous areas are narrow and curved; interporiferous areas lanceolate, about half as wide again as a poriferous area. Apical disk anterior, $8 \mathrm{~mm}$. from the anterior border and $9.5 \mathrm{~mm}$. from the posterior border of the test. Peristome and periproct are invisible, as they are covered up by matrix on the ventral side. The most remarkable feature of this species is the tubercles; dorsally there are 6 large, perforate primary tubercles, sunken in deep pits, the upper part of the tubercles being flush with the surface of the test; 2 of these large sunken tubercules are situated in interambulacrum 1 and there are also 2 in interambulacrum 4 . In the anterior interambulacra 2 and 3 there is in each area one of these large tubercles, a most distinctive and, as far as I know, unique character in the Clypeastroida. ${ }^{1}$ Secondary tubercles of medium size are scattered over

${ }^{1}$ What at first sight looks like a second tubercle in interambulacrum 3 , and lying close to the petal of ambulacrum III, is a local imperfection and not a tubercle. 
the test dorsally; ventrally they are similar, but more closely associated. There are 4 genital pores, the pore being absent in area 5 , as is typical in the genus. Several madreporic pores exist.

There are 2 specimens of this new species. The larger measures $3 \mathrm{~mm}$. in height, $18 \mathrm{~mm}$. in length, and $17 \mathrm{~mm}$. in width. The fact that there are only 4 genital pores indicates that this species should be referred to the genus Peronella.

This species is remarkable in the large primary tubercles which occur on the dorsal side. The only clypeastroid apparently to which it can be compared is the Recent Clypeaster lampas H. L. Clark (C. latissimus A. Agassiz, Blake Echini, plate 15c), in which species there are a number of large tubercles on the ventral side; but they are not sunken in pits and are quite numerous instead of very limited in number. A better comparison structurally of the peculiar large tubercles in Peronella mirabilis is to compare them with similar tubercles seen in the spatangoids Lovenia and the Recent Maretia tuberculata A. Agassiz and Clark (1917, Mem. Mus. Comp. Zoöl., vol. 46, No. 2, plate 160, figs. 5 to 7). In this comparison with spatangoids the similar character is a pure case of parallelism.

The second specimen, which is somewhat smaller and less perfect than the holotype, is instructive in that it shows a similar distribution of the large primary tubercles, 2 in interambulacrum 4 and 1 in interambulacrum 3. They also doubtless existed similarly in interambulacra 1 and 2, but these areas are worn away. This species was associated in the same lot with Echinolampas ovumserpentis, as collected by J. A. Bullbrook.

Eocene, San Fernando formation, Vitabella Road, Mount Moriah, San Fernando, Trinidad, J. A. Bullbrook collector; 2 specimens, U. S. Geol. Sur. station 8878; the holotype, U. S. Nat. Mus. No. 328247; and a paratype, U. S. Nat. Mus. No. 328248.

\section{Family SCUTELLIDE Agassiz, 1841.}

\section{Genus ECHINARACHNIUS Gray, 1825 .}

Type species.-Scutella parma Lamarck, 1816, Anim. sans Vert., vol. 3 , p. 11

\section{Echinarachnius sebastiani, new species.}

\section{(Plate 7, Figures 5, 6; Text-figure 4.)}

The following is a description of this species:

Test very thin, wider than long, flat on the lower side, arched on the upper side, with very thin margin. Apical disk central. Petals wide, rounded and open at the distal tips, being wider open in the large specimen than in the two small ones, which I take to be immature. Surface of the test closely set with small tubercles. The details of the apical disk can not be made out, but it is central in position. The periproct is on the posterior margin in a small reëntrant notch. The peristome is quite hidden by the 
matrix in the two smaller specimens, but in the large one it is preserved in part with traces of the Aristotle's lantern in what appears to be about the middle of the test.

The material of this species consists of 2 small specimens and a large one. The largest is four-rayed and imperfectly preserved, so that although it is of considerable interest as an abnormal departure from the typical pentamerous symmetry, I hesitate to make it a holotype. The holotype selected is the more perfect of the two smaller specimens. It measures $25 \mathrm{~mm}$. in length, $28 \mathrm{~mm}$. in width, and about $3.5 \mathrm{~mm}$. in thickness. The other small specimen is nearly of the same size. The large specimen, which is fourrayed, is seen from the ventral side with considerable of the test broken away, so that it is a combination view of the exterior of the ventral side and the interior of the dorsal side. No complete measurements can be given, but from the periphery to the center it measures $47 \mathrm{~mm}$., so that the whole diameter would be about twice that amount or in the vicinity of $94 \mathrm{~mm}$. Three ambulacral petals of the dorsal side are seen viewed from within and the 3 are

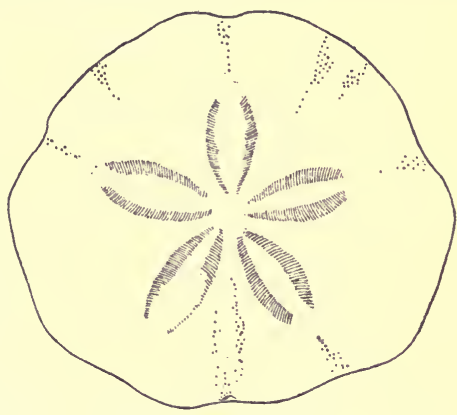

FIG. 4,-Echinarachnius sebastiani, new species. Holotype, $\times 2$. placed at right angles to each other in the plane of their main axes; that is, they present an angle of about $90^{\circ}$ to one another instead of an angle of about $72^{\circ}$, which is characteristic of the 5 ambulacra of Echinarachnius and other Echini that are not bilaterally elongate. This angle of $90^{\circ}$ in the specimen in hand indicates clearly that a fourth petal would complete the circuit of the test. I described (Phylogeny of the Echini, p. 49) a partially six-rayed Recent Echinarachnius parma, but this is the first four-rayed specimen of the genus known. Six-rayed Echini are exceedingly rare, and I have only seen 6 more or less completely six-rayed specimens in a careful examination of some 55,000 specimens of Recent and fossil Echini. More or less completely four-rayed specimens are, however, much commoner. It may be noted here that a four-rayed Clypeaster concavus is figured in plate 2, figure 12, and recently I have seen in the Museum of Comparative Zoölogy a partially four-rayed Clypeaster rosaceus from the Tortugas, Florida.

Echinarachnius sebastiani finds its nearest allied form apparently in the Recent Echinarachnius parma (Lamarck). It differs from that species in that it is wider than long and in the extreme thinness of the test, especially on its marginal border. 
Oligocene; the smaller specimens are from the Collazo shales, Collazo River, $5 \mathrm{~km}$. east of San Sebastian, Porto Rico, collected by Mr. Rabell; holotype and paratype, 2 specimens, station 116, Amer. Mus. Nat. Hist. No. 18570 . The larger four-rayed specimen is from shaly limestone, Rabell's Ranch, $11 \mathrm{~km}$. northeast of San Sebastian, Porto Rico, collected by C. A. Reeds, station 115, Amer. Mus. Nat. Hist. No. 18571. All are from the Expedition of the New York Academy of Sciences, the Porto Rican Government and the American Museum of Natural History coöperating.

Genus ENCOPE Agassiz, 1841.

Type species.-Echinodiscus emarginatus Leske, 1778, Add. ad Klein, p. 136.

As the genera Encope and Mellita are represented in the living fauna on both the east and west coasts of tropical America, and the genus Encope is known from several species occurring fossil in the Panama Canal Zone, it is perhaps singular that so little is known of these genera as occurring fossil in the West Indies.

I described 3 species of Encope from the Miocene, Gatun formation, of the Panama Canal Zone as new, namely, E. annectans, platytata, and megatrema (1917, Proc. U. S. Nat. Mus., vol. 53, pp. 489 to 501, plates 62 to 68 ). When that paper was published, by oversight an article by Franz Toula was overlooked (Die jung-tertiäre Fauna von Gatun am Panama Kanal, Jahrb. Geol. Reichsant., Wien, vol. 61, pp. 487 to 530 , plates 30 and 31, 1911). In his paper Toula described as new Encope gatunensis. The species I described as platytata is near to but probably distinct from gatunensis. The similarities are in the flatness of the test and the narrowness and long posterior extension of the ambulacral petals I and V. The differences are that the lunule in interambulacrum $\mathbf{5}$ is short and rounded in platytata, whereas it is long and slit-like in gatunensis. Both species are represented only by fragmentary specimens, platytata being wanting in the posterior portion of the test and gatunensis wanting in the anterior portion. Unless further material should prove the identity of these species, it seems they had best be considered close but distinct.

Key to the West Indian Fossil Species of Encope.

Test large, longer than wide................................... cia

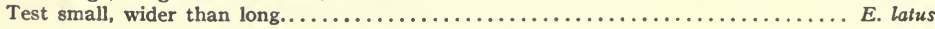

Encope ciæ de Cortázar.

Encope cia de Cortázar, 1880, Bol. Com. Mapa Geol. Espafía, vol. 7, p. 227, plate G, figs. $1 a$ to $3 a$; plate н , figs. $1 a, 2 a$. Cotteau, 1881, Ann. Soc. Géol. Belgique, vol. 9, p. 17; 1897, Bol. Com. Mapa Geol. Espafia, vol. 22, p. 44, plate 13, figs. $1 a$ to $3 a$; plate 14, figs. $1 a, 2 a$.

This fine large species, known only from a single specimen, is referred by Cotteau to the upper "Miocene" of Calabazar, in the environs of 
Havana, Cuba. It is in the collection of the Comisión del Mapa Geológico de España, Madrid.

Encope latus, new species.

(Plate 7, Figure 7; Text-figure 5.)

The following is a description of this species:

Test thin, very low, with very thin margin, wider than long. There is an oval, rounded lunule in interambulacrum 5, almost exactly halfway from the apical disk to the posterior border of the test. Deep notches or emarginations in ambulacra I and V, also II, and by inference in IV as well, though it can not be actually observed in this last-mentioned area. The emargination in ambulacrum III is very shallow. The apical disk is a trifle nearer the anterior border of the test than the posterior, being $20 \mathrm{~mm}$. from the anterior and $24 \mathrm{~mm}$. from the posterior border. From local imperfections, details of the apical disk can not be made out. The ventral side is completely hidden in the matrix, so that the character of the peristome and periproct can not be given. The ambulacral petals are relatively broad and rounded. Petals I and V measure $13 \mathrm{~mm}$. in length and are a little longer than petals II and IV, which measure $11 \mathrm{~mm}$. in length and evidently are longer than petal III, which, however, can not be measured, as it is imperfect distally.

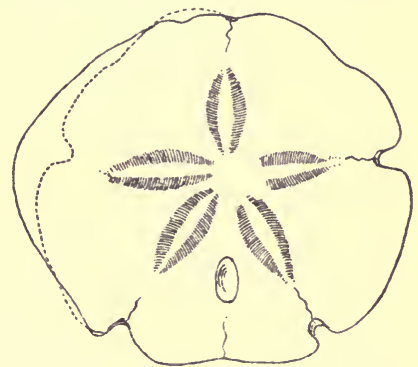

FIG. 5.-Encope latus, new species. Holotype, $\times 1$.

The single known specimen measures $43.5 \mathrm{~mm}$. in length, $46 \mathrm{~mm}$. in width, and about $4 \mathrm{~mm}$. in height. This species is very small and also extremely thin and light for the genus, and it is not at all impossible that the specimen described is an immature individual; it is, however, large enough so that it should have full species characters nearly or quite developed.

As the genital pores are not made out, it is possible that this species should be referred to Mellita, which has 4 genital pores, rather than Encope, which has 5. The specimen, however, has the look of an Encope, so that it is referred to that genus. Encope latus approaches E. annectans Jackson, of the Panama Canal Zone, but differs in the proportionate size of the ambulacral petals, for I and V are the shorter of all the areas in annectans. It also differs in the size, position, and depth of the lunule of interambulacrum 5 .

Miocene (?) from the "Arecibo" (?) limestone, Government Road, Aguadilla to Rincon, $\mathrm{km}$. post 10, Porto Rico, 1 specimen, the holotype, station 122, American Mus. Nat. Hist. No. 18572, C. A. Reeds collector, under the auspices of the New York Academy of Sciences, the Porto Rican Government and the American Museum of Natural History coöperating. 


\section{Genus MELliTA Agassiz, 1841.}

Type species.-Scutella quinquefora Lamarck, 1816, Anim. sans Vert., vol. 3 , p. $9=$ Echinodiscus quinquiesperforatus Leske, 1778, Add. ad Klein, p. 133.

\section{Mellita species.}

(Text-figure 6.)

The following is a description of this specimen:

Test elliptical, a little longer than wide. Very small, low, thin, with rounded edges. The ambulacral petals are rounded and rather short. A small oval lunule is in interambulacrum 5, nearer to the posterior border of the test than it is to the apical disk. There are slight emarginations in ambulacra I and V, which appear to be the beginnings of lunules formed by inclusion. The apical disk is central in position, but there are no genital pores visible, although the specimen is very well preserved. It would seem that the absence of the genital pores indicates the youth of the specimen.

This specimen measures $7 \mathrm{~mm}$. in length, $6 \mathrm{~mm}$. in width, and about $1 \mathrm{~mm}$. in height.

Comparing this evidently young individual with material in the Museum of Comparative Zoölogy, it is almost identical in structure with very young specimens of Mellita sexiesperforata (Leske) of about the same size.

It seems at first sight unreasonable to assume that the genus Mellita should be represented in the fossil state in the West Indies only by a specimen of such rarity as a very young individual. The only other reasonable view would be to assume that it is an

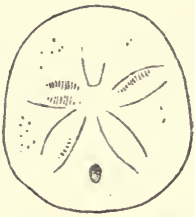

Fig. 6.-Mellita species, $X$ about 4 . adult, or at least relatively much older individual of a very small species. It would then be most primitive in structure, would not fit into the genus Mellita or any other genus at present known, and the absence of genital pores, which is only a youthful character in Echini, would not be accounted for other than by assuming rather extreme youth.

Miocene, Mayo Village Quarry (locality 11), Trinidad, F. W. Penny collector, U. S. Geol. Sur. station 8583 , U. S. Nat. Mus. No. 228244.

\section{Order EXOCYCLOIDA Jackson, I9I2.}

Suborder SPATANGINA Jackson, I9I2.

Of the Spatangina, there are many species occurring fossil in the West Indies, and including those which have been published but of which I have not seen material, there are more species than of all other Echini put together. Notwithstanding their relative abundance, the spatangoids are usually harder to study in that the material has much thinner tests and is therefore much more fragile and usually is not as well preserved. 


\section{Key to the West Indian Fossil Genera of Spatangina.}

1. Interambulacra all approximately alike orally, so that there is no sternum developed. even when the mouth is anterior.

A. Ambulacra not petaloid; test more or less depressed, peristome oblique.

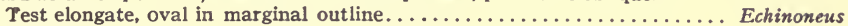

Test nearly or quite circular in marginal outline. .............A mblypygus

AA. Ambulacra all more or less petaloid.

B. All ambulacra petaloid or subpetaloid abactinally.

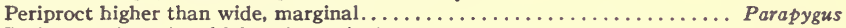

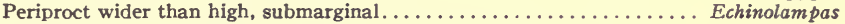

BB. Ambulacrum III conspicuously different abactinally from other ambulacra, which are broadly petaloid.

Ambitus oval or elliptical; petals not tending to close at ambitus........ Asterostoma

Ambitus subcircular; petals closing at ambitus.............. Pseudasterostoma

2. Interambulacrum 5 conspicuously different orally from the others, forming the so-called sternum.

A. Apical system elongate; genitals 2 and 3 meeting in mid-line, but separated from genitals 1 and 4 by oculars II and IV, only a marginal fasciole

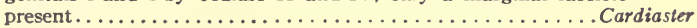

AA. Apical system not as above.

B. No true subanal fasciole, but a lateroanal fasciole is frequently present.

C. Peripetalous fasciole wanting anteriorly as it passes, on side of test, into a marginal fasciole which runs below the ambitus both anteriorly and posteriorly.

Ambulacra II and IV scarcely petaloid dorsally, the anterior series of pore-pairs

in each are greatly reduced or wanting ..................... Agssizia

Ambulacra II and $1 \mathrm{~V}$ petaloid; anterior series of pore-pairs normal . ...... Prenaster

CC. Peripetalous fasciole complete; no marginal fasciole.

D. Abactinal system ethmophract; no lateroanal fasciole; genital pores 4 . . Hemiaster

DD. Abactinal system ethmolytic.

E. Genital pores 4; lateral petals not deeply sunken.

Petals I and V much shorter than II and IV; test very wide....... Paraster

Petals I and V about as long as II and IV; test narrower......... Periaster

EE. Genital pores 2 or 3 ; all petals deeply sunken ................ Schizaster

BB. Subanal fasciole present.

F. No internal fasciole.

G. Petals, at least the paired ones, deeply sunken.

H. Ambulacrum III more or less petaloid, sunken........... Brissopsis

HH. Ambulacrum III not petaloid.

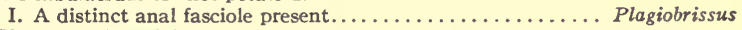

II. No anal fasciole.

Ambulacrum III sunken so that the ambitus is concave anteriorly,

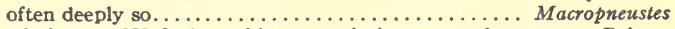

Ambulacrum III flush, ambitus anteriorly more or less convex.Brissus

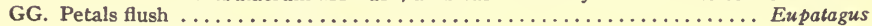

FF. Internal fasciole present....................... Breynia

Of the genera of the Spatangina found fossil in the West Indies, the following number of fossil species have been recognized:

Under Echinoneus 2 fossil species (see Key, p. 54).

Under Amblypygus only 1 fossil species, Amblypygus americanus.

Under Parapygus 2 fossil species (see Key, p. 56)

Under Echinalampas 7 fossil species (see Key, p. 57).

Under Asterostoma 2 fossil species (see Key, p. 67).

Under Pseudasterostoma only 1 fossil species, Pseudasterostoma jimenoi.

Under Cardiaster only 1 fossil species, Cardiaster cubensis.

Under Agassizia 2 fossil species (see Key, p. 70).

Under Prenaster only 1 fossil species, Prenaster loveni.

Under Hemiaster 4 fossil species (see Key, p. 73).

Under Paraster 5 fossil species (see Key, p. 75).

Under Periaster only 1 fossil species, Periaster elongatus.

Under Schizaster only 1 fossil species, Schizaster scilla.

Under Brissopsis 3 fossil species (see Key, p. 81).

Under Plagiobrissus only 1 fossil species, Plagiobrissus loveni. 
Under Macropmeustes 2 fossil species (see Key, p. 84).

Under Brissus 2 fossil species (see Key, p. 86).

Under Eupatagus 7 fossil species (see Key, p. 88).

Under Breynia only 1 fossil species, Breynia cubensis.

Family ECHINONEIDE A. Agassiz, 188r.

Echinoneidæ A. Agassiz, 1881 = Echinonidæ Wright, 1855 .

Genus ECHINONEUS Leske, 1778.

Type species.-Echinoneus cyclostomus Leske, 1778, Add. ad Klein, p. 109.

There seem to be only 2 species recognizable among the fossil species of this genus in the West Indies.

\section{Key to the West Indian Fossil Species of Echinoneus.}

Ambitus nearly circular, the shorter diameter being over 90 per cent of the longer.E. orbicularis Ambitus elliptical, the shorter diameter being less than 90 per cent and usually about 75 per cent of the longer .................................. cyclostomus

\section{Echinoneus orbicularis Desor.}

Echinoneus orbicularis Desor, 1846, Catalogue Raisonné, Ann. Sci. Nat., ser 3, vol. 7, p. 144. Cotteau, 1897, Bol. Com. Mapa Geol. Espafia, vol. 22, p. 47, plate 15, fig. 4.

This species is recorded by Cotteau as known fossil in the West Indies from a single specimen from Recent calcareous concretions in the island of Cuba. The specimen is in the d'Orbigny collection in the Paris Museum.

\section{Echinoneus cyclostomus Leske. \\ (Plate 9, Figures 4, 5.)}

Echinoneus cyclostomus Leske, 1778, Add. ad Klein, p. 109. Guppy, 1866, Quart. Jour. Geol. Soc. London, vol. 22, p. 301. Cotteau, 1897, Bol. Com. Mapa Geol. España. vol. 22, p. 48, plate 15, figs. 5 to 9. H. L. Clark, 1917, Mem. Mus. Comp. Zoöl., vol. 46, No. 2, p. 102.

Echinoneus semilunaris A. Agassiz, 1873, Revision of Echini, p. 118; 1883, Mem. Mus. Comp. Zoöl., vol. 10, No. 1, p. 90.

Echinoneus Cotteau, 1875, Kongl. Sven. Vet. Akad. Handl., vol. 13, No. 6, p. 14, plate 1. figs. 28 to 30 .

Echinoneus minor Guppy (non Leske), 1882, Scientific Assoc. Trinidad, Proc., part 12, p. 195.

The following is a description of this species:

Test oval, low, rounded, wider posteriorly than anteriorly. Peristome strongly elliptical, a little anterior to the middle of the test, set on a slant from the antero-posterior axis of the test. Periproct large, ovate, broadest anteriorly, situated halfway from the peristome to the posterior border of the test. Ambulacra apetaloid, flush with surface, narrow, and broadest above the ambitus. Poriferous areas are very narrow. Apical system a little anterior to the middle of the test, but the details of apical plates or pores could not be made out. Tubercles small, not very closely associated dorsally; ventrally more closely associated, as shown in the figures.

This species is represented by a single specimen from Anguilla in the National Museum. Cotteau says that he had a single specimen in the Cleve collection from Anguilla, on which his figures were based. Guppy also had a single specimen from Anguilla, as stated by him in his published paper. Whether this specimen in the U. S. National 
Museum is the original of Guppy or Cleve is not certain, but it corresponds so well with Cotteau's figures that it is probably the Cleve specimen. Somewhat curiously, Cotteau did not feel that he could give a species name to Echinoneus as he described it on page 14 of the work cited, for his published figures are very good.

The specimen measures $7.5 \mathrm{~mm}$. in height, $17 \mathrm{~mm}$. in length, and $12.5 \mathrm{~mm}$. in width. It is interesting to find that this species, which is living at the present time in the West Indian fauna as well as in the Pacific Ocean, should be found fossil in such comparatively ancient geological deposits. It was in this species that Mr. A. Agassiz described (1909, Amer. Jour. Sci., vol. 28, pp. 490 to 492, plate 2) the most interesting fact that the young of Echinoneus has a lantern, it being at present the only known case of this structure occurring in the spatangoids.

Oligocene, Anguilla formation, Anguilla, Guppy collection ex Cleve (or possibly from the original Guppy collection), 1 specimen, probably the original of Cotteau's, 1875, plate 1, figs. 28 to 30, U. S. Nat. Mus. No. 115402. Santiago de Cuba, 1 specimen, received January 1910, U. S. Nat. Mus. No. 328223. Cotteau, in his Spanish report, quoting A. Agassiz (Blake Echini), says that this species occurs in the Pliocene of Cuba and Guadeloupe, also the Miocene [Oligocene] of Anguilla.

\section{Genus AMBLYPYGUS Agassiz, 1846-7.}

Type species.-Amblypygus apheles Agassiz, 1847. Cat. Raisonné, Ann. Sci. Nat., ser. 3, vol. 7, p. 166.

\section{Amblypygus americanus Desor.}

Amblypygus americanus Desor, 1858, Synopsis des Échinides fossiles, p. 256.

The following is a description of this species:

Large species, circular in marginal outline, with high rounded border, flattened dome-shaped above, concave below, ambulacra wide, $15 \mathrm{~mm}$. at the ambitus, slightly elevated, non-petaloid, continuous over the border to the peristome. The poriferous areas of the ambulacra are depressed, 4 $\mathrm{mm}$. wide at the widest part, which is about midway from the ambitus to the apical disk and from this broadest part narrowing adapically and adorally. The apical disk is small, excentric anteriorly. The peristome is a little excentric anteriorly and is small, but the outline is not clear on the plaster cast from which these observations are made. It is, however, doubtless obliquely elongate, as in other species of the genus. The peristome is evidently smaller than the periproct as noted by Desor. The periproct is large, elongate pyriform, measuring $21 \mathrm{~mm}$. in length and $12 \mathrm{~mm}$. in its greatest width. The peristome is situated on the ventral surface halfway from the peristome to the posterior border of the test. Details of the apical disk, outlines of plates, and tubercles are not distinguishable on the plaster cast.

The specimen measures $37 \mathrm{~mm}$. in height, $93 \mathrm{~mm}$. in length, and $90 \mathrm{~mm}$. in width.

This species was described by Desor, but has apparently never been figured. He states that the original is in the Michelin collection. The observations here made are based on a plaster cast bearing the 
original number of "Y. 5," which is the number given by Desor as the type of the species. It is from the Louis Agassiz collection, which was received at the Museum of Comparative Zoölogy in 1859. Duncan and Sladen (1883, Palæontologia Indica, ser. 14, p. 13) publish some notes on the species based on a specimen in the British Museum.

This species closely resembles Amblypygus merrilli Twitchell (1915, Monograph U. S. Geol. Sur., vol. 54, p. 165, pls. 76, 77, 78, figs. $1 a$ to $1 b$ ), but the test in americanus is much lower, not conical as in merrilli. Twitchell described $A$. merrilli from the Ocala limestone of Florida, and this formation was then considered as Oligocene. According to latest authority, however (see p. 110), the Ocala limestone is considered as Eocene.

Tertiary, doubtless Eocene, Jamaica. A plaster cast of the type (orig. No. Y. 5), L. Agassiz collection, subscription of 1859, Mus. Comp. Zoöl. No. 724.

\section{Family NUCLEOLITIDE Gregory, 1900.}

The family name Nucleolitidæ is used to replace the old name Cassidulidæ, which had to be abandoned, since Cassidulus is preoccupied, all as set forth by H. L. Clark, 1917, Mem. Mus. Comp. Zoöl., vol. 46, No. 2, p. 103.

Genus PARAPYGUS Pomel, 1883.

Type species.-Botriopygus toucasanus d'Orbigny, 1855, Paléontologie Française, vol. 6, Echini, p. 340, plate 931.

The name Parapygus must replace Echinanthus as used by Desor, Duncan, Cotteau, and others. For full account of this change, see H. L. Clark, 1911, Ann. Mag. Nat. Hist., ser. 8, vol. 7, p. 594.

Key to the West Indian Fossil Species of Parapygus.

Periproct marginal; test about half as high as long; petals tend to close......... antillarum Periproct supramarginal; height of test over 60 per cent of length; petals not tending

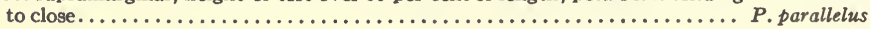

\section{Parapygus antillarum (Cotteau).}

(Plate 9, Figures 6 to 9.)

Echinanthus antillarum Cotteau, 1875, Kongl. Sven. Vet. Akad. Handl., vol. 13, No. 6, p. 26, plate 4, figs. 9 to 12 ; 1897 , Bol. Com. Mapa Geol. España, vol. 22, p. 52, plate 16. figs. 1 to 4 . Non Gregory, see p. 39.

The following is an extract from the original description of this species:

Species of medium size, rounded anteriorly, subtruncate posteriorly; upper face swollen, thick on the sides, subcarinate posteriorly; lower face nearly flat, a little hollowed antero-posteriorly. Apical disk anterior to the center. Ambulacral areas petaloid, slightly swollen, fairly broad, contracting at their tips, the two posterior petals a little longer than the others. Poriferous areas a little depressed, with unequal pores, the internal rounded, the external narrow, elongated, and oblique. The poriferous areas cease being petaloid at a considerable distance from the ventral border; the pores become very small and disappear among the tubercles, which are small, crowded, homogeneous, and everywhere very abundant. 
The peristome is excentric anteriorly, stelliform, and is furnished with a very apparent floscelle. The periproct is narrow, elongate, supramarginal, opening on the posterior face at the summit of a groove, slightly indicated and surmounted by a slight expansion of the test.

Height, $25.5 \mathrm{~mm}$., length, $48 \mathrm{~mm}$., width, $34 \mathrm{~mm}$. These measurements do not correspond very closely with those given by Cotteau, but the specimen is somewhat distorted and he may have allowed for this. The sutures of the plates in the type are nearly or quite invisible, as are also the genital pores. I saw no trace of the ambulacra below the petals or at all on the ventral side of the test, but the tubercular ornamentation of the test is clearly preserved.

Eocene, St. Bartholomew limestone, St. Bartholomew, cotype, the original of Cotteau's figures, Guppy collection ex Cleve, 1 specimen, U. S. Nat. Mus. No. 115417. Two additional specimens, apparently cotypes, both good for the ventral side showing the peristome, St. Bartholomew, Guppy collection ex Cleve, U. S. Nat. Mus. No. 115420. Cotteau cites specimens from the Eocene of Santa Lucia, Cuba.

Parapygus parallelus (Cotteau).

Echinanthus parallelus Cotteau, 1897, Bol. Com. Mapa Geol. Espafía, vol. 22, p. 53, plate 12 , figs. 8 to 13 .

This species is referred by Cotteau to Azpeita, but with him it is simply a manuscript name with no standing. I have not seen material of this species, of which Cotteau says it is common in the Eocene deposits of Santa Lucia, Province of Santa Clara, Cuba.

\section{Genus ECHINOLAMPAS Gray, 1825 .}

Type species.-Echinanthus ovatus Leske, 1778, Add. ad Klein, p. 127.

There are many fossil species of this genus in the West Indies and the characters run so close they are hard to distinguish. H. L. Clark (1917, Mem. Mus. Com. Zoöl., vol. 46, No. 2, p. 111) also says that the Recent species of this genus are very hard to distinguish from one another. None of the fossil species is at all near to the Recent species of the West Indies.

Key to the West Indian Fossil Species of Echinolampas.

Size very large; ambitus nearly circular; test high.................... E. semiorbis Size moderate or small; ambitus more or less elliptical or oval.

Lateral margins of interporiferous areas of petals straight and diverging.

Periproct marginal; interporiferous areas of petals flat............... Entillarum

Periproct submarginal; interporiferous areas of petals slightly tumid...... E. ovumserpentis

Lateral margins of interporiferous areas of petals convex, converging slightly near the tip.

Test long, narrow; petals, especially the posterior pair, short; peristome anterior, periproct marginal ............................................

Test wider; petals longer; peristome central or subcentral.

Test more or less flattened, or if high, not at all subconical; petals short, wide, with unequal or subequal poriferous areas; peristome only a little sunken..E. lycopersicus

Test high and subconical; poriferous areas of lateral petals often quite unequal.

Height of test 60 per cent of length; poriferous areas of posterior petals about equal; peristome slightly sunken.................................. castroi

Height of test about 50 per cent of length; poriferous areas of posterior petals quite unequal; peristome deeply sunken..................... anguilloe 


\section{Echinolampas semiorbis Guppy.}

(Plate 10, Figures 1 to 3.)

Echinolampas semiorbis Guppy, 1866, Quart. Jour. Geol. Soc. London, vol. 22, p. 299, plate 19, fig. 7. Cotteau, 1875, Kongl. Sven. Vet. Akad. Handl., vol. 13, No. 6, p. 24, plate 5, figs. 1, 2; plate 6, fig. 1; 1897, Bol. Com. Mapa Geol. España, vol. 22 , p. 55 , plate 17 , figs. 1, 2; plate 18, figs. 1, 2 . Lambert, 1915, Mém. Soc. d'Agric. de l'Aube (Troyes), vol. 79, p. 20.

The following is an extract from Cotteau's description of this species:

Species of large size, subcircular, a little longer than wide; upper face high, regularly arched, hemispherical; lower face nearly flat, rounded on the borders, subconcave in the middle. Apical disk nearly central, slightly anterior. Ambulacral areas are not elevated, but petaloid, nearly straight, long, widely open at the ends, nearly equal; the posterior pair I and V, however, a little longer than the others. Poriferous areas very well developed, a little depressed, with very unequal pores; the internal pores are rounded, the external long, narrow, and oblique. The poriferous areas in the anterior ambulacra II, III, and IV cease to be petaloid at a considerable distance from the ambitus. In the posterior ambulacra I and V, they preserve their petaloid forms a little nearer to the ambitus. Toward the ambitus and lower face the pores become single, very small, widely spaced, and scarcely visible among the tubercles. They reappear and increase around the peristome. Tubercles are strongly scrobiculate, crowded, similar everywhere, abundant, a little more widely spaced at the approach to the mouth. [There are minute granules in the intertubercular spaces on exceptionally well preserved specimens.] Peristome transverse, narrow, subpentagonal, furnished with a floscelle, opening in the middle of the depression of the lower face; a little excentric anteriorly, corresponding in position to the apical disk dorsally. Periproct oval, transverse, inframarginal. Apical disk compact, prominent, remarkable for the development of the madreporite, which fills the middle of the disk. The two anterior genital pores 2 and 3 are nearer together than are the two posterior pores 1 and 4.

This species is one of the most distinctive of all the species of Echinolampas occurring fossil in the West Indies. A fine large specimen in the U. S. National Museum (No. 115386), labeled as the type, measures $50 \mathrm{~mm}$. in height, $107 \mathrm{~mm}$. in length, and $97 \mathrm{~mm}$. in width. It shows the ornamentation and ventral characters well, but does not show suture lines. Another specimen in the U. S. National Museum (No. 115383 ) is almost an exact duplicate of the above, but is not quite as well preserved, as some plates are wanting; however, it is better in some respects, as the madreporite and characteristic 4 genital pores are clearly preserved and the orriamentation is fine.

This species, semiorbis, is distinguished from the other West Indian fossil forms by its great size, high dome-shaped test, and flat base. It is very abundant in the island of Anguilla, where Guppy says it is used as a pound weight by the inhabitants. Doctor Vaughan, in collecting at Anguilla, obtained no less than 34 finely preserved specimens, which are strikingly alike in form and even in size. The most obvious difference as a matter of variation is that in some individuals the apical disk is set farther forward than in others, resulting in a more marked posterior 
slope of the test from the apical disk to the ambitus. While apparently most abundant in the island of Anguilla, E. semiorbis has quite a wide distribution, having been found in Cuba and the Panama Canal Zone.

Cotteau, 1875, gives the locality for this species as St. Bartholomew, and this is repeated in his Spanish report, 1897. It is, however, an entire mistake. This error was strongly pointed out by Guppy in 1911. ${ }^{1}$ Also, Vaughan tells me that no such material is found in St. Bartholomew. The geological horizon of the rocks in St. Bartholomew is Eocene and the lithological facies is entirely distinct from the Anguilla rocks. The fossils of St. Bartholomew are dark blue-gray, whereas those from Anguilla are a light yellowish-buff.

Oligocene, Anguilla formation, Guppy collection, cotype, figured by Guppy in Quart. Journ. Geol. Soc., plate 19, fig. 7, U. S. Nat. Mus. No. 115386. Another specimen from Anguilla, Guppy collection, also labeled as a type [cotype], U. S. Nat. Mus. No. 115383. Whether either of these two specimens is the original of Cotteau's 1875 figures is not certain; but the first one mentioned, and here reproduced (No. 115386), may well have been the basis of his published figures. Cotteau mentions having specimens from Cuba in his own collection. Crocus Bay Hill, roadside descent to Crocus Bay from Valley, Anguilla, T. W. Vaughan collector, 1914, 4 specimens, U. S. Geol. Sur. station 6893. Crocus Bay, Anguilla, T. W. Vaughan collector, 1914, 24 specimens, U. S. Geol. Sur. station 6894. Southwest side of Crocus Bay, 30 to 50 feet above sea-level, Anguilla, T. W. Vaughan collector, 1914, 6 specimens, U. S. Geol. Sur. station 6966. Lambert reports from the "Miocene" of Anguilla numerous specimens of semiorbis in the British Museum. Oligocene, Finca Carillo, near River Hanabana, El Caimito, Cuba, from Dr. Carlos de la Torre collection, 1 specimen, beautifully preserved, Mus. Comp. Zoöl. No. 3231.

In addition to the above localities for this species, Cotteau gives San Martin, Matanzas, Cuba, collection of Comisión del Mapa Geológico de España. It also occurs in the Oligocene Emperador limestone of the Panama Canal Zone, Las Cascadas, Gaillard Cut, several specimens, collected by D. F. Macdonald and T. W. Vaughan, U. S. Geol. Sur. stations $5866 b$ and $6019 G$.

Echinolampas antillarum Cotteau.

(Plate 9, Figures 10 to 12.)

Echinolampas antillarum Cotteau, 1875, Kongl. Sven. Vet. Akad. Handl., vol 13, No. 6, p. 19 , plate 3 , figs. 9 to 12 .

Echinolampas ovumserpentis Guppy (pars), 1882, Scientific Assoc. Trinidad, Proc., part 12, p. 196.

The following is an extract from the original description of this species:

Species of medium size, oval, elongate, rounded anteriorly, subtruncate posteriorly; upper surface very little swollen, lower face cushion-shaped;

${ }^{1}$ Quart. Jour. Geol. Soc. London, vol. 67, p. 685. 
rounded on the border, concave in the middle. Apical disk subcentral [anterior to the center]. Ambulacral areas are narrow, elongate, nearly straight, flush, narrowing at the tips, which, however, are widely open. The posterior ambulacra I and V are a little longer than the others; poriferous areas are narrow, not depressed, with unequal pores; the internal rounded, the external elongate, narrow, and oblique. The poriferous areas only cease to be petaloid at a very short distance from the border. Tubercles are scrobiculate, scattered, abundant, a little less crowded on the upper face than in the marginal region. Peristome opening in a depression of the lower face. Periproct transversely elongate, angular, placed very near the border.

There is only a single specimen in the Washington collection. It measures $15.5 \mathrm{~mm}$. in height, $33 \mathrm{~mm}$. in length, and $29 \mathrm{~mm}$. in width. Of this species Cotteau says it is very rare, but he does not say how many specimens he had, other than mentioning both the Cleve collection and the Museum at Upsala. The Cleve specimen differs so much in measurement from Cotteau's figures, and moreover is so imperfectly preserved, both dorsally and ventrally, that it is quite probable that Cotteau figured and made use of the Upsala specimen rather than this one in his description. This species is very close to Echinolampas lycopersicus, the similarity being in general configuration, in the anterior position of the apical disk, and in the large oval periproct. Cotteau pointed out the resemblance to lycopersicus, but distinguished it by the fact that the ambulacra are narrower, straighter, longer, and less petaloid. The test is more concave ventrally and the periproct is situated farther posteriorly. Guppy treated antillarum as a form of ovumserpentis, but I think the previous comparison is much closer. It is to be noted that lycopersicus is from the Oligocene, whereas both antillarum and ovumserpentis are Eocene.

Eocene, St. Bartholomew limestone, St. Bartholomew, Guppy collection ex Cleve, 1 specimen, cotype, U. S. Nat. Mus. No. 115401. The label refers this specimen to Cotteau's plate 3, figures 9 to 11 , but it seems more likely, from the discrepancies of the specimen and figures, that these figures were taken from the Upsala Museum specimen, which Cotteau mentions in his text.

\section{Echinolampas ovumserpentis Guppy. \\ (Plate 10,' Figures 4, 5.)}

Echinolampas ovumserpentis Guppy, 1866, Quart. Jour. Geol. Soc. London, vol. 22, p. 300 , plate 19, figs. 4a, b, 5, 6. Cotteau, 1875, Kongl. Sven. Vet. Akad. Handl., vol. 13, No. 6, p. 20, plate 3, figs. 13 to 21; 1897, Bol. Com. Mapa Geol. España, vol. 22, p. 62 , plate 16 , figs. 5 to 9 .

The following is an extract from Cotteau's description of this species:

Species of medium size, elongate, narrow, and rounded anteriorly; a little dilated and truncate posteriorly. Upper face high, more or less rounded above, sometimes subdepressed, having its greatest height corresponding to the apical disk; lower face strongly cushion-like, rounded on the borders. The apical disk is nearly central, more often a little pos- 
terior. Ambulacral areas petaloid, subcostulate, very open distally, and yet contracted a little at the ends. The anterior ambulacrum III longer, straighter, and narrower than the others; the anterior pair II and IV is shorter than the posterior pair. Poriferous areas strongly developed, with very unequal pores, the internal rounded, the external long, narrow, and transverse. Near the ambitus the areas cease to be petaloid and the pores are reduced, as in all species of Echinolampas, to single series ranged obliquely and scarcely visible in the midst of the tubercles; the poriferous areas then converge in nearly a straight line to the peristome, around which, without being very numerous, the pores appear to draw together and increase a little. Tubercles are strongly scrobiculate, homogeneous, and disposed without order, everywhere very abundant. Peristome relatively large, subpentagonal and angular [sunken, opening a little posterior to or] in the middle of the lower face. Periproct small, subcircular, inframarginal, a little removed from the posterior border. The apical disk is compact, slightly developed, and prominent. The madreporite is very extended, forming a large part of the apical disk. Four genital pores, very open; the anterior pair nearer together than the posterior pair. Ocular plates are angular, very small, in direct contact with the madreporic plate.

This species is very abundant in Trinidad and St. Bartholomew. Measurements are taken from a Trinidad specimen in the collections of the U. S. National Museum (No. 115389). Height, $19 \mathrm{~mm}$., length, $42 \mathrm{~mm}$., width, $33 \mathrm{~mm}$.

A large and very beautiful series of specimens from Trinidad, collected by J. A. Bullbrook, are fine for a study of variation and for structure as well, as they are beautifully preserved. Some of these are broad and flattened, strongly resembling lycopersicus; others are high and rounded, as is typical of the species. The material came in after this manuscript was finished and too late to make use of it further than by this brief note.

A large collection of specimens of this species made by Vaughan in St. Bartholomew, with other material, gives good opportunity for seeing the range of variation in this species, which is considerable. Some are wide and quite flat, others narrow, elongate, rounded, and high; the apical disk is quite uniformly close to the center of the test or a little posterior.

Echinolampas ovumserpentis approaches nearest to lycopersicus of all the West Indian fossil species, but is distinguished from that by a number of characters. In ovumserpentis the apical disk is central or slightly posterior; the ambulacral petals are truncate and extend nearer to the ambitus; the tuberculation is coarser, with tubercles relatively farther apart. There are typically 3 tubercles in a line across the interporiferous area of an ambulacral petal; the periproct is very small and farther from the posterior border; the peristome is more angular and more deeply sunken. On the other hand, in lycopersicus the apical disk is anterior, not central; the ambulacral petals are flaring at the tips and do not extend so near to the ambitus; the tuberculation is finer, with tubercles more crowded. There are typically 6 
tubercles across the interporiferous area of an ambulacral petal; the periproct is much larger and nearer the posterior border of the test; the peristome is less angular and less sunken than in ovumserpentis.

The material in Washington consists of several lots from Trinidad, the type locality, and from St. Bartholomew. Cotteau says that besides the Cleve collection he had specimens from the museums of Stockholm and Upsala.

Specimens of Echinolampas ovumserpentis from Jamaica are associated with Cidaris foveata and from Trinidad are associated with Peronella mirabilis, both as here described.

Eocene, San Fernando formation, San Fernando, Trinidad, Guppy collection, labeled as types [cotypes] and figured, Quart. Jour. Geol. Soc., vol. 22, 7 specimens, U. S. Nat. Mus. No. 115389. San Fernando, Trinidad, Guppy collection, also labeled as types [cotypes], 6 specimens, all much worn, U. S. Nat. Mus. No. 115409. Trinidad, cotypes, W. M. Gabb collection ex Guppy, 5 specimens, Philadelphia Acad. Nat. Sci. No. 3352. Vitabella Road, Mount Moriah, San Fernando, Trinidad, J. A. Bullbrook collector, a series of 27 specimens of young and adult, beautifully preserved, U. S. Geol. Sur. station 8878 .

Eocene, St. Bartholomew limestone, St. Bartholomew, Guppy collection ex Cleve, 6 specimens, labeled as original of Cotteau's plate 3, figs. 13 to 21, U. S. Nat. Mus. No. 115392. Anse Écaille, side of point between Anse Écaille and Anse Lézard, from conglomerate and sandstone below upper limestone bed, St. Bartholomew, T. W. Vaughan collector, 1914, 5 specimens, U. S. Geol. Sur. station 6897. Point between Anse Lézard and Anse Écaille, St. Bartholomew, T. W. Vaughan collector, 1914, 1 specimen, U. S. Geol. Sur. station $6897 a$. From a conglomerate and shaly bed interbedded with limestone, below the main limestones and at top of the conglomerate series of beds, point between Colombier Point and bay next to St. Jean Bay, St. Bartholomew, T. W. Vaughan collector, 1914, 10 specimens; specimens from this locality run exceptionally low and flat for the species; U. S. Geol. Sur. station 6897b. Northwest side of St. Jean Bay, along sea-face, St. Bartholomew, T. W. Vaughan collector, 1914, 4 specimens, U. S. Geol. Sur. station 6905. Point northwest side of St. Jean Bay, from bed of limestone, St. Bartholomew, T. W. Vaughan collector, 1914, 67 specimens (many of these are very well preserved for structural detail), U. S. Geol. Sur. station 6924. From conglomerate bed below limestone at top of section or partly from lower limestone bed just above conglomerate, St. Bartholomew, T. W. Vaughan collector, 1914, 2 specimens, U. S. Geol. Sur. station 6925. Spur on southeast side of bay northwest of St. Jean Bay, St. Bartholomew, 170 feet above sea-level, 1 specimen, T. W. Vaughan collector, U. S. Geol. Sur. station 6895. This last-mentioned specimen is very unusual in its flatness and also in its exceptional width, in which it simulates the 
broad, low forms of $E$. lycopersicus, seen as variations in large collections of that species.

Eocene, Jamaica, from yellow marl or limestone (probably from Cambridge formation), 1 specimen, Mus. Comp. Zoöl. No. 3235. Magazique, Cuba, Dr. Carlos de la Torre Coll., 1 specimen, Mus. Comp. Zoöl. No. 3232. Cotteau also records the species from Matanzas, Cuba, Coll. Comisión del Mapa Geológico de España, Madrid.

\section{Echinolampas clevei Cotteau.}

(Plate 10, Figures 6, 7; Plate 11, Figures 1, 2.)

Echinolampas clevei Cotteau, 1875, Kongl. Sven. Vet. Akad. Handl., vol. 13, No. 6, p. 23, plate 4, figs. 1 to 5. Guppy, 1882, Scientific Assoc. Trinidad, Proc., part 12, p. 196. Cotteau, 1897, Bol. Com. Mapa Geol. España, vol. 22, p. 61, plate 19, figs. 4 to 6 .

The following is an extract from the original description of this species:

Species of medium size, very elongate, subcylindrical; upper face high, rounded, subangular anteriorly and posteriorly, marked posteriorly by a vague, attenuated ridge. Lower side cushion-like, somewhat prominent in the posterior interambulacral area, rounded on the borders. The apical disk is very excentric anteriorly. Ambulacral areas wide, petaloid, not costate, contracted at their lower extremity, which is slightly open, especially in the anterior pair II and IV, unequal. The anterior ambulacrum III is narrower and nearly straight, the anterior pair II and IV relatively very short; the posterior pair I and V are distinctly longer. Poriferous areas are not depressed, formed of unequal pores, the internal rounded, the external elongate, narrow, and oblique. The poriferous areas cease to be petaloid a long distance from the border. Tubercles scrobiculate, scattered, abundant. The peristome is small, subpentagonal, appearing to open flush with the test. Periproct little developed, oval, subtriangular, wholly inframarginal.

A small immature specimen measures $16 \mathrm{~mm}$. in height, $25 \mathrm{~mm}$. in length, and $18 \mathrm{~mm}$. in width. A large specimen measures $25 \mathrm{~mm}$. in height, $49 \mathrm{~mm}$. in length, and $35 \mathrm{~mm}$. in width. An exceptionally large specimen, plate 11 , figures 1 and 2 (No. 115374), which is evidently the one especially mentioned by Cotteau for its size, measures $50 \mathrm{~mm}$. in height, $77 \mathrm{~mm}$. in length, and $55 \mathrm{~mm}$. in width. This species, by its elongate form and extreme roundness of outline and height, differs from other species of the genus occurring fossil in the West Indies. It also differs by its short ambulacral petals and by its small periproct.

Eocene, St. Bartholomew limestone, St. Bartholomew, Guppy collection ex Cleve, 2 specimens, cotypes, labeled as the originals of Cotteau's plate 4, figures 1 and 5, U. S. Nat. Mus. No. 115419. St. Bartholomew, Guppy collection ex Cleve, cotype, the original of Cotteau's plate 4, figure 4, 1 specimen, U. S. Nat. Mus. No. 115374. Cotteau says that he also had material of this species from the Upsala Museum, which probably was the original of two of his figures. $\mathrm{He}$ later records clevei from Matanzas, Cuba, the material being in the collection of the Comisión del Mapa Geológico de España, Madrid. 


\section{Echinolampas lycopersicus Guppy.}

(Plate 11, Figures 3 to 6.)

Echinolampas lycopersicus Guppy, 1866, Quart. Jour. Geol. Soc. London, vol. 22, p. 300, plate 19, fig. 8. Cotteau, 1875, Kongl. Sven. Vet. Akad. Handl., vol. 13, No. 6, p. 21, plate 3, figs. 22 to 26; 1881. Ann. Soc. Géol. Belgique, vol. 9, p. 20; 1897, Bol. Com. Mapa Geol. España, vol. 22, p. 59, plate 19, figs. 1 to 3. Lambert, 1915, Mém. Soc. d'Agric. de l'Aube (Troyes), vol. 79, pp. $21,29$.

The following is an extract from Cotteau's description of this species:

Species of large size, oval, elongate, rounded anteriorly, a little angular posteriorly; upper face moderately swollen, thick on the borders; lower face nearly flat, slightly cushion-like, subconcave around the peristome. Apical disk excentric anteriorly, ambulacral areas wide, petaliform, subcostulate, very open distally and yet distinctly contracted at the lower end. Poriferous areas depressed, with very unequal pores, the internal rounded, the external long, narrow, transverse. At some distance from the ambitus the ambulacra cease to be petaloid and are reduced to very small pores directly superposed. Around the peristome the pairs of pores are more apparent and increase a little. Tubercles scrobiculate, crowded, homogeneous, everywhere abundant. The peristome is narrow, a little excentric anteriorly, sensibly elongate in the transverse direction, and furnished with a very evident floscelle. Periproct transverse, elliptical, inframarginal. Apical disk compact, granular, circular, and furnished with four large genital pores.

A specimen which is apparently the original one figured by Guppy measures $22 \mathrm{~mm}$. in height, $40.5 \mathrm{~mm}$. in length, and $30.5 \mathrm{~mm}$. in width. A larger specimen in the same lot of cotypes measures $27 \mathrm{~mm}$. in height, $53 \mathrm{~mm}$. in length, and $46.5 \mathrm{~mm}$. in width. This species, which is very abundant in the islands of Anguilla and Porto Rico, is very uniform in character and varies principally in the height of the test. While most specimens are quite low, some, especially from Porto Rico, are much higher and dome-shaped.

Echinolampas lycopersicus is very similar to $E$. ovumserpentis. A comparison of the two species is made under the description of the latter. The essential distinction of lycopersicus is the anterior position of the apical disk, the larger size of the periproct, the flatness of the lower side, and the shallowness of the peristome. Also, the petals are shorter and less unequal. E. lycopersicus is also very close to anguillce, from which it differs in its less massive form and less deeply sunken peristome.

Oligocene, Anguilla formation, Ánguilla, Guppy collection, cotypes, being Guppy's original material, 6 specimens, all well preserved, U. S. Nat. Mus. No. 115388. Anguilla, IV. M. Gabb collection ex R. J. L. Guppy, cotypes, 3 specimens, Philadelphia Acad. Nat. Sci. No. 3353. Anguilla, Guppy collection ex Cleve, labeled as the originals of Cotteau's plate 3 , figures 22 to 26 , to which they closely correspond, 3 specimens, U. S. Nat. Mus. No. 115387. Cotteau mentions that besides the Cleve collection he had material of this species from the Stockholm Museum. 
Crocus Bay, Anguilla formation, southwest side, from rubble above shore-line, Anguilla, T. W. Vaughan collector, 1914, 2 specimens, U. S. Geol. Sur. station 6864. Crocus Bay Hill, roadside descent to Crocus Bay from Valley, Anguilla, T. W. Vaughan collector, 1914, 3 specimens, U. S. Geol. Sur. station 6893. Crocus Bay, southwest side, Anguilla, T. W. Vaughan collector, 1914, 31 specimens, U. S. Geol. Sur. station 6894. Crocus Bay, southwest shore, from lowest 10 to 15 feet of fossiliferous marls, Anguilla, T. W. Vaughan collector, 1914, 1 specimen, U. S. Geol. Sur. station 6965. Crocus Bay, 30 to 50 feet above sea-level, Anguilla, T. IV. Vaughan collector, 1914, 32 specimens, U. S. Geol. Sur. station 6966. Lambert reports numerous specimens from the "Miocene" of Anguilla. He also reports a single specimen from the "Miocene" of Antigua, in which it appears to be rare, this being the only record for lycopersicus in the island of Antigua. The Antigua specimen and probably some Anguilla specimens were collected by J. W. Gregory in 1899, collection of British Museum.

Oligocene; Rabell's Ranch, $11 \mathrm{~km}$. northeast of San Sebastian, Porto Rico, shaly limestone, $1 \mathrm{~km}$. northeast of ranch house (a higher horizon than station 108), 30 specimens, stations 100 to 112,C.A. Reeds collector. Collazo shales, Government Road, San Sebastian to Lares, Porto Rico; kilometer post 28; collected from talus slope beneath limestone bluff some 50 feet in height; 3 specimens, station 51, C. A. Reeds collector. Collazo shales, Government Road, San Sebastian to Lares, Porto Rico, kilometer post 29, from 11 to 12 feet of bluish shale exposed along roadside; 1 specimen, station 63, C. A. Reeds collector. "Arecibo" to Lares Road, km. 16, Porto Rico, collected from fresh limestone fragments thrown out from a cistern excavation along side of road; 7 specimens, station 509, C. A. Reeds collector. Collazo shales, Collazo River, 5 km. east of San Sebastian, Porto Rico; collected from stream bank below third waterfall, 20 to 100 feet below height of bridge on Government Road, 1 specimen, station 36, C. A. Reeds collector. Cliff face, east shore of Guanica Harbor, Porto Rico, 300 feet south of small cave (of station 341); beds of shaly limestone, somewhat stratified, 1 specimen, station 375, C. A. Reeds collector. "Arecibo" limestone, Corozal, Porto Rico, 1 specimen, station 555, Professor N. L. Britton collector. "Arecibo" formation, limestone escarpment northwest of Utuado, Porto Rico, 1 highly crystalline specimen, station 554, H. E. Anthony collector, 1916. All of above Porto Rican material collected on the expedition of New York Academy of Sciences, the Porto Rican Government and the American Museum of Natural History coöperating.

Oligocene; mountain near Candelaria, Pinar del Rio Province, Cuba, W. Palmer collector, 1917; 1 specimen, U. S. Nat. Mus. No. 324447. Near Santiago, Cuba, De la Torre collector; 1 specimen, Philadelphia Acad. Nat. Sci. No. 3349. San Martin, Guamutas, 
Cuba, Poey collection; 1 specimen, Philadelphia Acad. Nat. Sci. No. 3350. Cotteau records this species from the "Miocene" of San Martin, Matanzas, Cuba.

\section{Echinolampas castroi Cotteau.}

Echinolampas castroi Cotteau, 1881, Ann. Soc. Géol. Belgique, vol. 9, p. 19, plate 2, figs. 3 to 6; 1897, Bol. Com. Mapa Geol. Espana, vol. 22, p. 57, plate 3, figs. 3 to 6.

Cotteau ascribes this species to the Eocene and says it is rare, environs of Matanzas, Cuba, and that he has material in his own collection.

\section{Echinglampas anguillæ Cotteau.}

(Plate 11, Figures 7 to 9.)

Echinolampas anguilka Cotteau, 1875, Kongl. Sven. Vet. Akad. Handl., vol. 13, No. 6, p. 24, plate 4, figs. 6 to 8. Guppy, 1911, Quart. Jour. Geol. Soc. London, vol. 67, p. 692. Lambert, 1915, Mém. Soc. d'Agric. de l'Aube (Troyes), vol. 79, p. 30.

Echinolampas lycopersicus Guppy (pars), 1882, Scientific Assoc. Trinidad, Proc., part 12. p. 196.

The following is an extract from the original description of this species:

Species of large size, elongate, rounded, and a little narrowed anteriorly, more dilated and slightly subrostrate posteriorly; upper face swollen, elevated, subconical, sloping on the sides, having its greatest height through the apical disk. Lower face subcushion-like, rounded on the borders, deeply depressed in the middle. Apical disk excentric anteriorly. Ambulacral areas are wide, petaloid, subcostulate, and very open distally, though somewhat contracted at that point. The anterior ambulacrum III is straighter and a little narrower than the others, the posterior pair I and $\mathrm{V}$ is longer. Poriferous areas are depressed, formed of very unequal pores, the internal being rounded, the external long, narrow, and transverse. At a certain distance from the border the areas cease to be petaloid and the pores are reduced to single pores ranged by oblique pairs and very difficult to see among the tubercles. The tubercles are scrobiculate, crowded, homogeneous, and everywhere very abundant. The peristome is a little excentric anteriorly, appearing to be longer transversely, opening in a deep depression of the lower side. The periproct is transversely elliptical, subangular, and inframarginal.

There is only one specimen in the Guppy collection, and that appears to be the only one Cotteau had, as he says it is very rare and does not figure or mention any other. It measures $38 \mathrm{~mm}$. in height, $75 \mathrm{~mm}$. in length, and $60.5 \mathrm{~mm}$. in width. This species is very close to lycopersicus and seems to differ principally in its massive and subconical form. The type is more deeply concave ventrally than lycopersicus, which is very shallow in its ventral depression. It may be observed that other specimens that are referable to anguilla have a somewhat shallower ventral depression than the type. Guppy, in his 1882 paper, considered anguilla as simply an unusual form of lycopersicus, but it seems a fairly distinctive species to maintain.

Oligocene, Anguilla formation, Anguilla, Guppy collection ex Cleve, holotype, the original of Cotteau's plate 4 , figures 6 to 8,1 specimen, 
U. S. Nat. Mus. No. 115372. Slope about 100 feet above sea-level, between Little Harbor and Pelican Point, of Crocus Bay, Anguilla, T. W. Vaughan collector, 1914, 1 specimen, U. S. Geol. Sur. station 6971. Lambert records 3 specimens from the "Miocene" of Antigua, where it appears to be less rare than at Anguilla, collected by J. W. Gregory in 1899, collection of British Museum. Jique de la Argolla, Rio Seco de San Antonio, Guantanamo, Cuba, C. T. Ramsden collection, 2 specimens. Bissex Hill formation, Barbados (fide R. J. L. Guppy, 1911).

Family PLESIOSPATANGID $\approx$ Duncan, 1889.

Genus ASTEROSTOMA Agassiz, 1847 .

Type species.-Clypeaster excentricus Lamarck. See below.

There are 2 species of Asterostoma that have been recognized as occurring fossil in the West Indies.

Key to the West Indian Fossil Species of Asterostoma.

Peristome subcentral; ambulacra II and IV at ambitus about one-fifth as wide as inter-

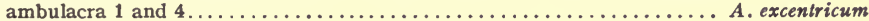

Peristome anterior; ambulacra II and IV at ambitus about two-fifths as wide as inter-

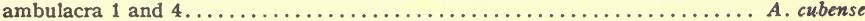

Asterostomma excentricum (Lamarck).

Clypeaster excentricuis Lamarck, 1816, Anim. sans Vert., vol. 3. p. 15.

A sterostoma excentricum Agassiz, 1847, Catalogue Raisonné, Ann. Sci. Nat., ser. 3, vol. 7, p. 168. Cotteau, 1871, Mém. Soc. Géol. de France, ser. 2, vol. 9, p. 183; 1897 , Bol. Com. Mapa Geol. España, vol. 22, p. 65, plate 20, figs. 1, 2.

This species, of which Cotteau had only a single specimen, which is in the Zoölogical Museum in Paris, is of doubtful locality, but Cotteau thinks, from the lithological character of the rock, that it comes from the same region as $A$. cubense Cotteau and Pseudasterostoma jimeno (Cotteau), both of which were described from the Eocene of Cuba.

\section{Asterostoma cubense Cotteau.}

A sterostoma cubense Cotteau, 1870, Comptes Rendus de l'Acad. des Sci., vol. 70, p. 273; 1871, Mém. Soc. Géol. de France, ser. 2, vol. 9, p. 181, plate 16, figs. 2 to 4 ; plate 17 , figs. 2 to $4 ; 1875$, Kongl. Sven. Vet. Akad. Handl., vol. 13, No. 6, pp. 6 and 46; 1881, Ann. Soc. Géol. Belgique, vol. 9, p. 27; 1897, Bol. Com. Mapa Geol. España, vol. 22 , p. 67 , plate 21 , figs. 1,2 .

The following is an extract from Cotteau's description of this species in the Annals of the Geological Society of Belgium:

Species of large size, a little elongate, rounded anteriorly, more narrow and slightly tapering posteriorly; upper face high, swollen, thick on the borders, sloping posteriorly, having its greatest height through the apical disk and its greatest width about the middle of the ambitus. Lower face nearly flat, concave at the approach to the peristome. Apical disk excentric anteriorly. The anterior ambulacrum III is very different from the others, flush with the test, widening toward the ambitus, having the poriferous areas with very small equal pores disposed in pairs. The paired ambulacra are very much more obvious, straight, descending low. The pores dorsally are unequal, the external elongate, the internal rounded, disposed in pairs 
on the outer borders of the ambulacral plates. These pores extend as far as the ambitus, where they cease abruptly and are replaced by other pores, smaller and scarcely visible. They spread out on the lower face at the approach to the peristome and are lodged in depressions which widen and extend directly to the mouth. Tubercles crenulate, perforate, and scrobiculate, unequal, abundant, and scattered all over the test, more crowded toward the ambitus and ventrally, nearly wanting in the ambulacral depressions. Granules are usually disposed in circles around the scrobicules. The peristome is very excentric anteriorly, transverse, elliptical, and opening in a depression of the lower side. Periproct posterior, a little above the ambitus.

Apical disk subcircular; madreporite slightly developed; the two posterior genital plates and the two posterior oculars are separated by a complementary plate [genital 5] which is imperforate, long, and angular, and extends to the madreporite.

As to measurements, Cotteau says the height is $66 \mathrm{~mm}$., length $121 \mathrm{~mm}$., and width $113 \mathrm{~mm}$. Cotteau publishes a good figure of a complete specimen in his Spanish report. It is there evident that the plate which separates the genitals 1 and 4 and the oculars I and V is an extension of the posterior genital 5, which is imperforate. He says (1897) that this species is very rare in the Eocene of Matanzas, Cuba, and the unique specimen figured is in his own collection in Paris. In Cotteau's (1875) memoir (p. 46) he says some specimens of large size from the Eocene of St. Bartholomew, while very incomplete, are perfectly recognizable as being this species by their high form, thickness, swelling, absence of the anterior groove, the narrow ambulacral areas, which are elongate, superficial, and the structure of the pores. He does not mention the Cleve collection, which is probably an oversight, as on page 46 he does not cite any source of the material, as is his custom. On page 6 he does mention having specimens of this species from St. Bartholomew in his own collection. Further, Guppy, in his 1882 paper, distinctly lists Asterostoma cubense as part of the material he received in the Cleve collection, so that undoubtedly this is the material referred to by Cotteau.

Eocene, St. Bartholomew limestone, St. Bartholomew, Guppy Collection ex Cleve; specimens described by Cotteau, 1875 , p. 46, 2 specimens, U. S. Nat. Mus. No. 115385. Cotteau gives as locality, Eocene, Matanzas, Cuba; the single known specimen from Cuba is in his collection in Paris.

Genus PSEUDASTEROSTOMA Duncan, 1889.

Type species.-Asterostoma jimenoi Cotteau. See below.

Pseudasterostoma jimenoi (Cotteau).

Asterosloma jimenoi Cotteau, 1870, Comptes Rend. Acad. des Sci., vol. 70, p. 273; 1871, Mém. Soc. Géol. de France, ser. 2, vol. 9, p. 180; pl. 16, fig. 1; pl. 17, fig. 1; 1897, Bol. Com. Mapa Geol. España, vol. 22, p. 69, plate 22, figs. 1, 2.

Cotteau, in his Spanish paper, says that this species is very rare in the Eocene deposits of Matanzas, Cuba; the unique specimen is in his own collection in Paris. 
Family ECHINOCORYTHIDE Gregory, 1900.

Genus CARDIASTER Forbes.

Type species.-Spatangus excentricus Woodward, 1833, Geology of Norfolk, p. 37, also [57], explanation of plate 1, fig. 5.

Cardiaster cubensis, new species.

(Plate 12, Figure 1.)

The following is a description of this species:

Test large, low, cordiform, with a deep sulcus anteriorly, bounded by a high rounded ridge on either side; posteriorly contracted to a rounded end; dorsally a rounded but sloping ridge runs from the apical disk to the posterior end. From this posterior sloping elevation and from the ridges bounding the anterior sulcus the surface of the test slopes in a gentle incline, right and left from the center to the ambitus. The ventral side is wanting, but the indications are that it was at least comparatively flat. The greatest height is through the apical disk, which is excentric posteriorly. The width and length of the test measure alike, and the height is about but somewhat more than one-third of the length. The ambulacra are non-petaloid, flush with the surface of the test, except the anterior, which is in a deep groove. The anterior ambulacrum III is much narrower than the other areas, but widening from the apical disk, passing toward the ambitus, the ambulacral plates are proportionately and actually higher than in the other areas, and the two pores in each plate are small and set at an oblique angle, the lower pore being the inner of each pair. Ambulacra of the anterior pair II and IV from the apex, where they are narrow, widen progressively to the ambitus, and present a strong, sweeping, forward curve in outline, the posterior side of each of these two areas presenting the more strongly curved outline. The pores of these ambulacra II and IV differ markedly on the two sides of each area. Starting dorsally near the apical disk, where the pores are all closely alike, being elongate and oval, and passing ventrally, the posterior row of pores in each area becomes long drawn out and almost slitlike and widely spaced. On the other hand, the pores of the anterior half of each of these two areas are rounded on the outer side and elongate oval on the inner side. Passing ventrally, the pores of these anterior half-areas move from the anterior end of each plate gradually, until at the ambitus they occupy the middle line (vertically) of the plates; here also both pores are smaller and rounded instead of larger and one elongate oval. On the anterior half of these two areas II and IV, the outer pores retain an approach to a circular form throughout the length of the area, but the inner series elongate, though not in anything like the degree that they do on the posterior halves of the same areas. The posterior ambulacra $\mathrm{I}$ and $\mathrm{V}$ are very much shorter and narrower than the anterior pair. They widen and curve forward somewhat in passing to the ambitus. The character and shape of the pores is similar to those of the anterior pair, but in a very much less degree. The apical disk is situated posteriorly, $35 \mathrm{~mm}$. from the posterior border and $56 \mathrm{~mm}$. from the anterior border of the test. The plates of the apical disk are in part preserved and genital 5 is absent, as is typical of the genus. Oculars IV and V meet the middle line of the area, but are separated from each other by genital 4, showing that it has the typical apical disk characteristic of the genus. The periproct is not observable, as the plates are broken away at the posterior end and nothing of the 
ventral side can be seen, as that area is quite gone. The surface of the test is covered with small, rather widely scattered tubercles, more closely associated near the ambitus, Small granules which doubtless existed between them are quite wanting, as the surface of the test is much worn.

Length, $91 \mathrm{~mm}$., width, also $91 \mathrm{~mm}$., the height as it stands measures $32 \mathrm{~mm}$., but this is somewhat less than the original height of the single known specimen, which is worn away ventrally.

This is the only species of the genus so far found fossil in the West Indies. It is very much larger and does not make a near approach to any species known in American formations.

Cretaceous, from high slopes in the valley of Rio Yateras, about 21 miles northeast of Guantanamo, Cuba, holotype, C. T. Ramsden collection.

Family HEMIASTERIDE H. L. Clark, 1917.

Genus AGASSIZIA Valenciennes, 1846 .

Type species.-Agassizia scrobiculata Valenciennes, 1846, Voyage de la Venus, Atlas, Zoöphytes, plate 1, figs. 2 to $2 f$.

Key to the West Indian Fossil Species of Agassizia.

Test high, conical, arched anteriorly, plastron strongly elevated . . . . . . . . . . A. inflala

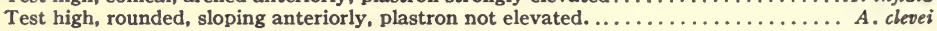

Agassizia inflata, new species.

(Plate 12, Figures 2 to 4.)

Agassizia clevei Cotteau (pars), 1875, Kongl. Sven. Vet. Akad. Handl., vol. 13, No. 6, p. 33 , plate 6 , figs. 9,10 , non 2 to 8 .

The following is a description of this species:

Species of small size, obovate; very widely rounded anteriorly; rounded but much narrower posteriorly; upper face very high, subconical; arched anteriorly from the apical disk to the ambitus; the greatest height is through the apical disk; posterior face truncate, nearly vertical. The sternum is strongly projecting, increasing in elevation to the anterior end of the plastron. The apical disk is excentric posteriorly; anterior furrow slight, but well marked dorsally, but it does not extend to the ambitus. The anterior ambulacrum III is straight and narrow, the plates higher than wide, with small pores near the middle of each plate. Ambulacra II and IV, the anterior pair, are very peculiar, the anterior half-ambulacrum being reduced to very narrow plates, nearly atrophied dorsally, with very small rounded pores. The posterior halves of ambulacra II and IV are much more obvious than the anterior halves, and extend farther toward the ambitus. The plates are low, relatively wide, with two vertical rows of large oval pores. The angle of divergence of ambulacra II and IV is less than that of $A$. clevei. The posterior ambulacra I and $\mathrm{V}$ are sunken in slight furrows, are longer than in clevei, and have relatively large oval pores, much as in the posterior halves of II and IV. Where not worn by erosion, small tubercles cover the test, being more closely crowded near the ambitus. The apical disk is small, but details can not be ascertained in this specimen excepting for the 4 genital pores, which are obvious. The periproct, transversely oval, is situated in the posterior face and is just visible from above; the peristome is semicircular, labiate, and situated 
far anteriorly, $5 \mathrm{~mm}$. from the anterior border. The plastron is wide, swollen, and ornamented with tubercles in regular, close-ranked series.

The single known specimen of this species measures $17 \mathrm{~mm}$. in height, $23 \mathrm{~mm}$. in length, and $20 \mathrm{~mm}$. in width.

The species Agassizia inflata is near to clevei, and the specimen here described was included in that species by Cotteau in his original description. Guppy made the remark, in his 1882 paper, that this was the only known case in which one species of Echini occurred in both the islands of St. Bartholomew and Anguilla. The species inflata differs from clevei in its wider and more conical form, in its anterior curvature from the apical disk to the ambitus, in its more marked furrow anteriorly, more elevated swollen plastron, and in the fact that ambulacra II and IV are both longer and less divergent than in clevei.

Eocene, St. Bartholomew limestone, St. Bartholomew, Guppy collection ex Cleve, holotype, 1 specimen only, U. S. Nat. Mus. No. 325610.

\title{
Agassizia clevei Cotteau.
}

(Plate 12, Figures 5 to 7.)

\begin{abstract}
Agassizia clevei Cotteau (pars), 1875, Kongl. Sven. Vet. Akad. Handl., vol. 13, No. 6, p. 33, plate 6, figs. 2 to 8; non 9, 10. Guppy (pars), 1882, Scientific Assoc. Trinidad, Proc., part 12, p. 197.
\end{abstract}

The following is an extract from the original description of this species:

Species of small size, ovoid, rounded anteriorly, a little narrower posteriorly; upper face very swollen, obliquely inclined anteriorly, having its greatest height through the apical disk. Posterior face narrow, truncate subvertically; a little reëntrant. The lower face is slightly projecting, depressed in front of the peristome. Apical disk excentric posteriorly, anterior furrow scarcely apparent on the upper face, wholly wanting at the ambitus. Anterior ambulacrum III straight, circumscribed by small pores disposed in pairs. The paired ambulacra are unequal, the anterior divergent, subflexuous, slightly excavated; the posterior shorter, nearly superficial. Pores of the anterior paired ambulacra II and IV very unequal. The anterior half-area is reduced in all its extent to very small pores, rounded, nearly microscopic, disposed in oblique pairs, forming a linear series which passes beyond the petals and extends to the peristome. The posterior half-area is much larger and composed of pores oblong and transverse. The two halves approach one another and leave scarcely place for a narrow interporiferous band. Pores of the posterior pair of ambulacra I and V always equal, nearly identical in distribution to the larger (or posterior) half of the anterior paired ambulacra II and IV. Tubercles are crowded, abundant; unequal, most developed on the anterior face and on the inframarginal region. On the lower face the interambulacral plastron is covered with scaly tubercles disposed in very regular divergent series. The space occupied by the posterior ambulacra, in place of being smooth, is finely granular. The peristome is semicircular, labiate, near to the [anterior] border. The periproct is subtransversely angular at the summit of the posterior face. Apical disk compact, slightly developed, with 4 genital pores, the 2 anterior much less separated than the two posterior. Madreporite elongate, narrow, and extended to the center of the apical disk, as in Prenaster. The peripetalous fasciole is narrow, sineous, 
incomplete. At some distance from the anterior ambulacrum it enlarges and goes to rejoin the marginal fasciole, which is sinuous and passes under the periproct in descending as far as the base of the posterior face.

One of the two specimens of this species in Washington measures $13 \mathrm{~mm}$. in height, $19 \mathrm{~mm}$. in length, and $15 \mathrm{~mm}$. in width. The second specimen is of about the same size. The relatively large specimen, of which Cotteau (1875) gives measurements in the last paragraph of his page 33, is evidently the one from St. Bartholomew, which is here considered a distinct species, $A$. inflata. While nearly allied, these species differ as set forth in the description of $A$. inflata.

Oligocene, Anguilla formation, Anguilla, Guppy collection ex Cleve, 2 specimens, cotypes, U. S. Nat. Mus. No. 115407. Besides the Cleve collection, Cotteau mentions having material from the museums of Stockholm and Upsala; he does not say whether they were from Anguilla or not. Southwest side of Crocus Bay, 30 to 50 feet above sealevel, Anguilla, T. W. Vaughan collector, 1914, 1 specimen, U. S. Geol. Sur. station, 6966.

\section{Genus PRENASTER Desor, 1853.}

Type species.-Prenaster alpinus Desor, 1853, Act. Soc. Helv. Sci. Nat., vol. 38 , p. 279 [12 of reprint].

\section{Prenaster loveni Cotteau.}

(Plate 12, Figures 8, 9.)

Prenaster loveni Cotteau, 1875, Kongl. Sven. Vet. Akad. Hand1., vol. 13, No. 6, p. 34, plate 6 , figs, 11 to 15 .

The following is an extract from the original description of this species:

Species of medium size, elongate, ovoid, rounded anteriorly; subcarinate posteriorly. The upper face is high, swollen, everywhere of about equal height. Posterior face vertically subtruncate, rounded; lower face uniformly rounded. Apical disk excentric anteriorly. Anterior furrow wholly wanting, even at the approach to the apical disc. Anterior ambulacrum III straight, with pores disposed in pairs of separated pores. The paired ambulacra are subpetaloid, slightly concave, open at their extremity, unequal; the anterior long, nearly transverse [at an angle of about $155^{\circ}$ to each other], the posterior shorter, more nearly convergent and forming an acute angle [of about $55^{\circ}$ ] posteriorly. Poriferous areas are wide, composed of transverse pores united by a furrow, unequal, the internal oval, the external more elongate. The interporiferous areas are well developed and depressed in the middle. Peristome semicircular and near the anterior border. Periproct oval, opening on the posterior face. The tubercles, apical disk, and fascioles are not known in this species, and it is only by reason of its form, position of the ambulacra, and absence of the anterior furrow that it is placed in the genus Prenaster.

The only specimen in the collection measures $20 \mathrm{~mm}$. in height, $23 \mathrm{~mm}$. in length, and $20 \mathrm{~mm}$. in width. The periproct is high up on the posterior end and is just visible from above, though not so shown in Cotteau's figures. This is quite natural, for a so nearly globular specimen shows 
more or less, according as it is tilted. The anterior ambulacrum III is hardly visible and the mouth is visible, but not clearly outlined.

Eocene, St. Bartholomew limestone, St. Bartholomew, Guppy collection ex Cleve, holotype, 1 specimen only, the original of Cotteau's plate 6, figures 11 to 15 , U.S. Nat. Mus. No. 115411.

\section{Genus HEMIASTER Desor, 1847 .}

Type species.-Spatangus bufo Al. Brongniart, 1822, Cuvier's Oss. Foss., vol. 2, pp. 320, 604 .

There are 4 species of Hemiaster occurring as fossils in the West Indies; of these I have seen only 1 , which is here described as new.

\section{Key to the West Indian Fossil Species of Hemiaster.}

Posterior petals I and V not half as long as the antero-lateral II and IV.

Test abruptly narrowed posteriorly; petals II and IV moderately divergent.... H. cubensis

Test not narrowed posteriorly; petals II and IV extremely divergent....... H. antillensis Posterior petals $I$ and $V$ much more than half as long as II and IV.

Height of test over 80 per cent of length; test not sloping markedly to the front.. H. dewalquei

Height of test 50 to 60 per cent of length; test sloping markedly to the front..... H. berkeyi

\section{Hemiaster cubensis (d'Orbigny).}

Schizaster cubensis d'Orbigny in Agassiz and Desor, 1847, Catalogue Raisonné, Ann. Sci. Nat., ser. 3, vol. 8, p. 22.

Hemiasier cubensis Cotteau, 1881, Ann. Soc. Géol. Belgique, vol. 9, p. 41, plate 4, figs. 1 to 3; 1897. Bol. Com. Mapa Geol. España, vol. 22, p. 73, plate 25, figs. 1 to 3.

Cotteau cites this species as Pliocene or Recent, very rare in the island of Cuba; from the d'Orbigny collection in the Natural History Museum in Paris.

\section{Hemiaster antillensis Cotteau.}

Hemiester antibensis Cotteau, 1881, Ann. Soc. Géol. Belgique, vol. 9, p. 31. plate 3, figs. 1 to 4; 1897, Bol. Com. Mapa Geol. España, vol. 22, p. 72, plate 24, figs. 1 to 4.

Cotteau cites this species as Eocene(?), Santa Lucia and Concepción in the district of Cienfuegos, Province of Santa Clara, Cuba; collections of Dewalque in Liège and Comisión del Mapa Geológico de España, Madrid.

\section{Hemiaster dewalquei Cotteau.}

Hemiarter detrolquei Cotteau, 1881, Ann. Soc. Géol. Belgique, vol. 9, p. 30, plate 2, figs. 7 to 9; 1897, Bol. Com. Mapa Geol. Espania, vol. 22, p. 75, plate 3, figs. 7 to 9.

Cotteau cites this species as from the Eocene(?) of Cienfuegos, Cuba, very rare; collection of Dewalque in Liège.

\section{Hemiaster berkeyi, new species.}

(Plate 12, Figure 10.)

The following is a description of this species:

Test large, cordiform, high, subonnical, rounded telow, from the high:est point of the test dorsally sloping anteriorly, posteriorly, and laterally to 
the ambitus. Ambulacra petaloid, wide, in deep, broad furrows. The anterior ambulacrum III is narrower than the others and lies in a shallow furrow which reaches to the ambitus. Ambulacra II and IV, the anterior pair, are widely divergent, at an angle of about $95^{\circ}$ to each other and are in grooves, which extend nearly to the ambitus. They measure $30 \mathrm{~mm}$. in length. The posterior ambulacra $\mathrm{I}$ and $\mathrm{V}$ lie in grooves and are narrower and much shorter than the anterior pair, measuring about $18 \mathrm{~mm}$. in length. The pores in the paired ambulacra are at the ends of narrow, slit-like grooves. The interambulacra are narrow and elevated dorsally. The apical disk is very close to median in position, perhaps actually median, but, from imperfections posteriorly, exact measurement in the anteroposterior axis can not be made. The apical disk is quite well preserved and shows the 4 genital plates with large perforations; the madreporite is of medium size, meeting but not separating the other genitals. Oculars $\mathrm{I}$ and $\mathrm{V}$ are in contact on account of the absence of genital 5, as is characteristic of the genus. From imperfections the peristome and periproct are not preserved. Small perforate tubercles with scrobicules are scattered over the test somewhat distantly and small granules thickly cover the spaces between the larger tubercles.

The specimen measures $40 \mathrm{~mm}$. in height, and this is a close approximation to the real height; if not worn ventrally, it would be slightly higher. It measures about $65 \mathrm{~mm}$. in length and $65 \mathrm{~mm}$. in width. This species is very much larger and more conical than any other fossil species of the genus from the West Indies; it differs also in its shape from any known North American species. At the request of the collector, Mr. Graham John Mitchell, this species is named in honor of Professor Charles P. Berkey, of Columbia University.

Cretaceous, Guanica Central, just west of the town of Guanica, South coast of Porto Rico, holotype, 1 specimen, station 211. This fossil echinoid, with a few other fossils, is from a dense, hard limestone from the upturned and unconformable beds of the older formation, which Professor Berkey ${ }^{1}$ considers as Cretaceous. It was collected by $\mathrm{Mr}$. Graham John Mitchell, who had charge of the Ponce district in the survey work of 1917.

\section{Genus PARASTER Pomel.}

Type species.-Schizaster gibberulus Agassiz, 1847, Catalogue Raisonné, Ann. Sci. Nat., ser. 3, vol. 8, p. 22.

All of the species described by Cotteau in his St. Bartholomew and Anguilla memoir as Schizaster belong properly to the genus Paraster. There are no Recent species of Paraster in the West Indian region, so far as we yet know. The genus Schizaster is characterized by having only 2 genital pores, which are in genital plates 1 and 4 , whereas the genus Paraster has 4 genital pores, 1 in each of the genital plates existent. Genital 5 is absent typically in both genera.

${ }^{1}$ Scientific Survey of Porto Rico and the Virgin Islands. New York Acad. Sci., vol. 1, part $1,1919$. 
Key to the West Indian Fossil Species of Paraster.

A. Test about as wide as long; apical system central or a little posterior.

B. Ambulacrum III scarcely depressed at ambitus; petals II and IV nearly straight, very widely diverging $\ldots \ldots \ldots \ldots \ldots \ldots \ldots \ldots \ldots \ldots \ldots \ldots \ldots, P$. antillarum

BB. Ambulacrum III much depressed at ambitus; petals II and IV slightly curved; not so widely diverging.

C. Petals II and IV curved outward at tip somewhat abruptly; petals I and V three-fourths as long as II and IV, narrow and somewhat

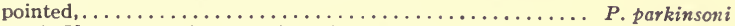

CC. Petals II and IV not curved outward at tip; petals I and $\mathrm{V}$ not much more than half as long as II and IV, wide and rounded.

D. Interambulacra 1, 4, and 5 near apical system, much elevated and somewhat compressed; petals widest near or just distal to middle, tapering more or less towards each end; test rounded pentagonal.....P. clevei

DD. Interambulacra 1, 4, and 5 not much elevated or compressed; petals widest near tip; test more evenly oval................ loveni

AA. Test not nearly as wide as long; apical system markedly posterior .....P. subcylindricus

\section{Paraster antillarum (Cotteau).}

(Plate 13, Figures 1 to 3 .)

Schizaster antillarum Cotteau, 1875, Kongl. Sven. Vet. Akad. Handl., vol. 13, No. 6, p. 28 , plate 5 , figs. 3 to 5 .

Schizaster subcylindricus Guppy (pars), 1882, Scientific Assoc. Trinidad, Proc., part 12, p.197.

The following is an extract from theoriginal description of thisspecies:

Species of medium size, nearly as wide as long, subcordiform, expanded anteriorly and acuminate posteriorly. Upper face swollen, sloping anteriorly, having its greatest height a little posterior to the apical disk. The posterior face is narrow, subangular, obliquely truncate. Lower face slightly swollen, rounded on the borders, sub-depressed anterior to the peristome. Apical disk subcentral, a little posterior. Anterior furrow wide, deep dorsally and attenuated toward the ambitus. Anterior ambulacrum III narrow, elongate, and straight, with simple pores in pairs. The paired ambulacra are petaloid, subflexuous, excavated, closed at the ends and unequal. The anterior ambulacra II and IV are longer than the posterior pair; poriferous areas with pores which are alike elongate and narrow, united by a furrow; interporiferous areas narrower than the poriferous. Interambulacra are narrow, compressed, and prominent near the apex. The peristome is semicircular, near the anterior border. Periproct oval, situated in the posterior face. Peripetalous and subanal fascioles are indistinct, yet visible enough to show they are like those of Schizaster.

There is only one specimen in the collection in Washington, which measures $20.5 \mathrm{~mm}$. in height, $28 \mathrm{~mm}$. in length, and $27.5 \mathrm{~mm}$. in width. These measurements greatly exceed Cotteau's, for he says $11 \mathrm{~mm}$. in height, $17 \mathrm{~mm}$. in length, and $16 \mathrm{~mm}$. in width. However, he mentions having 2 specimens, both badly preserved, and his measurements were doubtless taken from the other specimen, which I can not locate. It is probable that Cotteau's figures were also taken from this second specimen mentioned, as the one in hand does not show some of the features he depicts. The periproct is in the upper part of the posterior face, as Cotteau describes it, but is indistinct, so does not come out well in the photograph of the posterior view. The specimen is so much worn that it shows very little of structural detail. This species (antillarum) differs from clevei in the shape of the test and the shape and depth of the anterior 
furrow and lateral petals, and it differs from loven $i$ in the same characters. It differs in the furrow, petals, and general shape from subcylindricus, to which species Guppy referred it as a synonym; in fact, it is closer to clevei, as mentioned, than it is to subcylindricus, so that perhaps Guppy made a lapsus calami in this comparison.

Eocene, St. Bartholomew limestone, St. Bartholomew, Guppy collection ex Cleve, 1 specimen, cotype ( 2 specimens are mentioned by Cotteau), U. S. Nat. Mus. No. 115404. From a conglomerate and shaly bed interbedded with limestone below the main limestones and at the top of conglomerate series of beds, point between Colombier Point and bay next St. Jean Bay, St. Bartholomew, T. W. Vaughan collector, U. S. Geol. Sur. station 6897b, 1 specimen. Point northwest side of St. Jean Bay, from bed of limestone at top of described section, St. Bartholomew, T. W. Vaughan collector, 2 specimens, U. S. Geol. Sur. station 6924.

\section{Paraster parkinsoni (Defrance).}

Spatangus parkinsoni Defrance, 1827, Dict. des Sci. Nat., vol. 50, p. 96.

Schizaster parkinsoni Agassiz, 1847, Catalogue Raisonné, Ann. Sci. Nat., ser. 3, vol. 8, p. 22. Cotteau 1881, Ann. Soc. Géol. Belgique, vol. 9, p. 38. A. Agassiz, 1883, Mem. Mus. Comp. Zoöl., vol. 10, No. 1, p. 94. Cotteau, 1897, Bol. Com. Mapa Geol. Espafina, vol. 22, p. 84, plate 27, figs. 1 to 3 .

This species, known from a number of European localities, is also recorded from the West Indies. Cotteau refers to it specimens from the "Miocene" of Matanzas, Cuba, Cotteau collection. A. Agassiz lists this species from the "Miocene" of Anguilla.

\section{Paraster clevei (Cotteau).}

(Plate 13, Figures 4, 5.)

Schizaster clevei Cotteau, 1875, Kongl. Sven. Vet. Akad. Handl., vol. 13, No. 6, p. 29, plate 5, figs. 7, 8. Brown, 1914, Proc. Acad. Nat. Sci., Philadelphia, vol. 65, p. 601.

Schizaster loveni Guppy (pars), 1882, Scientific Assoc. Trinidad, Proc., part 12, p. 197.

The following is an extract from the original description of this species:

Species of medium size, very obliquely sloping anteriorly, subcordiform; marked posteriorly by an attenuated carina. Posterior face, truncate subvertically, lower face rounded on the borders, slightly swollen. Apical disk excentric posteriorly. Anterior furrow narrow, very deep, with high ridges on the borders, while reduced toward the ambitus, it extends as far as the peristome. Anterior ambulacrum III straighter and longer than the others, having the poriferous areas much less developed than the interval which separates them. The paired ambulacra are deeply excavated, wide, unequal; the anterior II and IV are subflexuous, divergent; the posterior ambulacra I and $\mathrm{V}$ are shorter, rounded at their tips, having the poriferous areas wider than the interval which separates them. The peristome, periproct, and a part of the fascioles are not visible in the fragmentary specimen.

Height, $27 \mathrm{~mm}$.; length, $40 \mathrm{~mm}$. (this is the length of this individual specimen, but as it is very imperfect posteriorly, another specimen might naturally give different proportions); width, $39 \mathrm{~mm}$. Ambulacrum III is in a very deep furrow; the paired ambulacra are also in deep depressions; the petals of ambulacra II and IV measure $15 \mathrm{~mm}$. in length, but I and V 
are shorter, measuring $10 \mathrm{~mm}$. in length. The periproct is quite wanting, as the specimen is broken away posteriorly.

Cotteau says that this species is very rare and mentions only the Cleve collection. There is only one specimen in Washington, and it agrees so closely with Cotteau's figures, it is undoubtedly the one from which the drawings were made, although it does not show all the details there depicted. This species is certainly very close to $P$. loveni, but it seems that Cotteau's distinctions are well taken, as clevei is narrower, more swollen, and especially has the posterior ambulacra I and V longer and deeper than in loveni.

Oligocene, Anguilla formation, island of Anguilla, Guppy collection ex Cleve, 1 specimen, holotype, U. S. Nat. Mus. No. 115408. Antigua formation, Willoughby Bay, Montpelier, St. Phillips, Antigua, Dr. A. P. Brown collector, 1 specimen, Philadelphia Academy of Natural Sciences, No. 1663.

\section{Paraster loveni (Cotteau). \\ (Plate 13, Figures 6 to 9.)}

Schizaster scilloe Guppy (non Agassiz), 1866, Quart. Jour. Geol. Soc. London, vol. 22, p. 301. Schizaster loveni Cotteau, 1875, Kongl. Sven. Vet. Akad. Handl., vol. 13, No. 6, p. 29, plate 5 , figs. 9 to 13. Guppy, 1882, Scientific Assoc. Trinidad, Proc., part 12, p. 197.

The following is an extract from the original description of this species:

Species good-sized, subcordiform, expanded anteriorly, and subcarinate posteriorly. Upper face thick, moderately swollen, obliquely inclined anteriorly and posteriorly; marked posteriorly by a very attenuated carina. Posterior face subvertically truncate; lower face nearly flat, rounded toward the ambitus; a little swollen in the middle, depressed in front of the mouth. Apical disk subcentral, slightly posterior. Anterior furrow wide, deep, subcarinate on the sides, attenuated towards the ambitus, prolonged as far as the peristome. Anterior ambulacrum III straighter and longer than the others, having its poriferous areas much narrower than the interval which separates them. The paired ambulacra are deeply excavated, very unequal, the anterior pair II and IV subflexuous, divergent; the posterior pair $I$ and $V$ are much shorter, rounded at the tips, having the poriferous areas wider than the space which separates them. Peristome transverse, labiate, near the anterior border. Periproct elliptical, opening at the summit of the posterior face. Peripetalous fasciole very sinuous.

In the U. S. National Museum there are 5 specimens of this species, one large and the rest small. The large one measures $26 \mathrm{~mm}$. in height, $43 \mathrm{~mm}$. in length, and $41 \mathrm{~mm}$. in width. A smaller specimen, very perfectly preserved, especially ventrally, measures $18 \mathrm{~mm}$. in height, 28.5 $\mathrm{mm}$. in length, and $26 \mathrm{~mm}$. in width. Guppy, in 1882, says that the specimens from Anguilla which he, in 1866, referred to Schizaster scille, are the same as Cotteau's loveni. The anterior ambulacrum III lies in a deep furrow which is somewhat wider than in clevei; the anterior pair II and IV are in shallower and more open depressions than in clevei and measure $13 \mathrm{~mm}$. in length. The posterior ambulacra I and V, also in relatively shallow depressions, measure $8 \mathrm{~mm}$. in length. Cotteau compares loveni closely with parkinsoni, but I have not seen that species. 
He says it differs in that loveni is less swollen, in the divergence of ambulacra II and IV, and in the nearly central apical disk.

Oligocene, Anguilla formation, island of Anguilla, Guppy collection ex Cleve, 5 specimens, cotypes (the large one is apparently the original of Cotteau's plate 5, fig. 9), U. S. Nat. Mus. No. 115391. Besides the Cleve collection, Cotteau mentions having specimens from the museums of Stockholm and Upsala. Crocus Bay Hill, roadside descent to Crocus Bay from Valley, Anguilla, T. W. Vaughan collector, 2 specimens, U. S. Geol. Sur. station 6893. Crocus Bay, southwest side, Anguilla, T. W. Vaughan collector, 1914, 2 specimens, U. S. Geol. Sur. station 6894. Crocus Bay, southwest shore from the lowest 10 to 15 feet of fossiliferous marls, Anguilla, T. W. Vaughan collector, 1914, 3 specimens, U. S. Geol. Sur. station 6965. Crocus Bay Bluff, southwest side, from the uppermost horizon, 125 feet above sea-level, mostly limestone, Anguilla, T. W. Vaughan collector, 4 poorly preserved specimens, but doubtless referable to the species, U. S. Geol. Sur. station 6967. Specimens which are wanting in structural detail, but fairly referable to this species, Government Road, Aguadilla to Rincon, Porto Rico, "Arecibo" limestone, weathered marl, kilometer post 2, from roadside grottoes where road-metal had been taken out, C. A. Reeds collector, 7 specimens, station 117, Expedition of New York Academy of Sciences, the Porto Rican Government and American Museum of Natural History coöperating.

Paraster subcylindricus (Cotteau).

(Plate 13, Figure 10; Plate 14, Figures 1,2.)

Schizaster subcylindricus Cotteau, 1875, Kongl. Sven. Vet. Akad. Handl., vol. 13, No. 6, p. 31. plate 5, figs. 14 to 17. Guppy, 1882, Sci. Assoc. Trinidad, Proc., part 12, p. 197.

The following is an extract from original description of this species:

Species of small size, oblong, rounded anteriorly, subtruncate posteriorly. The upper face thick, swollen, nearly as high in the anterior region as in the posterior, slightly sloping anteriorly. Posterior face vertically subtruncate. Lower face rounded on the borders, uniformly bulging, which gives a very remarkable subcylindrical aspect. Apical disk strongly excentric posteriorly. Anterior furrow wide, scarcely excavated, apparent only at the approach to the summit; very attenuate and nearly wanting toward the ambitus. The anterior ambulacrum III is quite different from the others, straight, with small pores, separate and widening in spacing, more as they approach the ambitus. The paired ambulacra are excavated, flexuous, scarcely open at the tips, very unequal; the posterior I and V are shorter than the others, having the poriferous areas distinctly wider than the interval which separates them. The interambulacra toward the apical disk are narrow, compressed, prominent. The peristome is semicircular, labiate near the anterior border. Periproct rounded, opening at the summit of the posterior face. Peripetalous fasciole less sinuous than in some species.

Of 4 specimens in Washington, the largest measures $20.5 \mathrm{~mm}$. in height, $30 \mathrm{~mm}$. in length, and $27 \mathrm{~mm}$. in width. This species is dis- 
tinguished from its near allies by its shallow and broad anterior furrow, which does not reach to the ambitus, by the shallow depressions of the paired ambulacral petals, by the far posterior position of the apical disk, and by its strongly rounded form. The periproct is very rounded on the upper part of the posterior face and is not visible from above.

Eocene, St. Bartholomew limestone, St. Bartholomew, Guppy collection ex Cleve, 4 specimens, cotypes, U. S. Nat. Mus. No. 115416. Cotteau also mentions having specimens from the museums of Stockholm and Upsala. From a conglomerate and shaly bed interbedded with limestone below the main limestones and at the top of the conglomerate series of beds, point between Colombier Point and bay next to St. Jean Bay, St. Bartholomew, T. W. Vaughan collector, 1914, 1 specimen, U. S. Geol. Sur. station $6897 b$.

\section{Paraster species a.}

The following is a description of the specimens:

Test of medium size, high, rounded, expanded anteriorly, and bluntly truncate; narrowed posteriorly. Upper face high, obliquely inclined from the highest point posteriorly. Border high, rounded, lower face rounded. Apical disk subcentral, a little posterior. Anterior furrow moderately deep, subcarinate on the sides dorsally, extended to the peristome. Anterior ambulacrum straight and narrow. The paired ambulacra are deeply excavated, very unequal. The anterior pair II and IV widely divergent, the posterior pair I and V much shorter, rounded at the tips. Peristome anterior, transverse. Periproct and fascioles not visible.

There are only 2 specimens, the larger being the better preserved. It measures $26 \mathrm{~mm}$. in height, $33 \mathrm{~mm}$. in length, and $29 \mathrm{~mm}$. in width. The specific identity, and even the generic, are doubtful on account of the lack of detailed structure, but it appears to be a Paraster and quite near to $P$. subcylindricus. Associated with Cidaris foveata, sp. nov., Echinolampas ovumserpentis, and Eupatagus sp. a, as here described.

Eocene, from yellowish limestone, probably the Cambridge formation of R. T. Hill, Jamaica, with no detailed locality; 2 specimens, Mus. Comp. Zoöl. No. 3236.

\section{Paraster species b.}

A specimen of Paraster that is too incomplete to describe as new and does not seem referable to any of the known species is of interest as being from the island of Trinidad, so it is briefly described.

Test moderately high, truncate anteriorly; pointed posteriorly; dorsally with a deep anterior furrow that extends over the ambitus and to the peristomal border. The ambulacra are completely obliterated, excepting ventrally, where they are seen extending to the peristome. The apical disk and periproct are also quite invisible. The peristome is situated far anteriorly; it is wide, labiate, and sunken. The specimen measures about $16 \mathrm{~mm}$. in height, $27 \mathrm{~mm}$. in length, and $23 \mathrm{~mm}$. in width. This specimen makes a close approach to Paraster loveni in form, but that species comes from the Oligocene and is probably distinct. 
Eocene, San Fernando formation, Vitabella Road, Mount Moriah, San Fernando, Trinidad, J. A. Bullbrook collector, 1 specimen, U. S. Geol. Sur. station 8878; U.S. Nat. Mus. No. 328225.

\section{Genus PERIASTER d'Orbigny, 1854 .}

Type species.-Periaster conicus d'Orbigny, 1854, Paléontologie Française, vol. 6, p. 274, plate 899.

The genus Periaster is very dubious. Duncan considers it a synonym of Linthia. Apparently no type-species has ever been definitely designated for the genus. If Periaster conicus d'Orbigny be now designated as the type, then the genus can be recognized and Cotteau's Periaster elongatus from St. Bartholomew can be considered as a valid Periaster. Cotteau says that the genus Periaster is distinguished from Schizaster by the fact that its posterior ambulacra are ordinarily more elongate.

\section{Periaster elongatus Cotteau.}

(Plate 13, Figure 11.)

Periaster elongatus Cotteau, 1875, Kongl. Sven. Vet. Akad. Handl., vol 13, No. 6, p. 27. plate 5 , fig. 6 .

Schizaster (Periaster) elongatus Guppy, 1882, Scientific Assoc. Trinidad, Proc., part 12, p. 196.

The following is an extract from the original description of this species:

The test is of medium size, elongate, hollowed, and expanded anteriorly; subacuminate posteriorly. Upper face high, swollen, strongly carinate posteriorly, having its greatest thickness a little behind the apical disk. Posterior face subangular and truncate. Apical disk very excentric anteriorly. Anterior furrow wide, deep, commencing at the apical disk and extending as far as the ambitus. The anterior ambulacrum III is different from the others, with small pores separated by a granuliform swelling and disposed in crowded pairs. The paired ambulacra are petaloid, subflexuous, strongly excavated, and very nearly equal in length. The anterior ambulacra II and IV are very divergent [at an angle of about $165^{\circ}$ to each other], nearly horizontal; the posterior I and $\mathrm{V}$ more converging, forming between them an acute angle [of about $40^{\circ}$ ]; poriferous areas are wider than the interval between them, with pores which are equal, transverse, elongate, and united by a furrow. The interambulacral areas are crowded, compressed, very prominent at the approach to the summit. Tubercles are abundant, small, unequal and scattered; the largest are in the anterior region on the border of the ambulacral furrow. The peristome, periproct, and apical disk are not visible in the only known specimen of the species.

The height can not be given exactly, as the base of the specimen is buried in matrix, but it is estimated to be about $18 \mathrm{~mm}$., the length is about $34 \mathrm{~mm}$., the width $24 \mathrm{~mm}$. While these measurements differ markedly from those given by Cotteau, I think there is no question that this is the specimen he figures, for he says that it is very rare, and the specimen is buried in matrix in the same way that he delineates. The species is distinguished from its near allies by its elongate form, apical disk excentric anteriorly, deep and wide anterior furrow, and the paired 
ambulacral petals of equal length; also by the fact that the interambulacra are strongly pinched up and prominent.

Eocene, St. Bartholomew limestone, St. Bartholomew, Guppy collection ex Cleve, 1 specimen, holotype, U. S. Nat. Mus. No. 115418.

Genus SCHIZASTER Agassiz, 1836.

Type species.-Schizaster studeri Agassiz, 1835, Prodrome Monographie Radiaires, Mem. Soc. Sci., Neuchatel, vol. 1, p. 185 [separate p. 18].

\section{Schizaster scillæ Agassiz.}

Schizaster scillœ Agassiz, 1847, Catalogue Raisonné, Ann. Sci. Nat., ser. 3, vol. 8, p. 21 (non Guppy, 1866, Quart. Jour. Geol. Soc. London, vol. 22, p. 301). Cotteau, 1881, Ann. Soc. Géol. Belgique, vol. 9, p. 35; 1897, Bol. Com. Mapa Geol. España, vol. 22 , p. 82 ; plate 26 , figs. 4,5 ; plate 27 , figs. 4 to 6 .

I have not seen material of this species. Guppy (1882, Scientific Assoc. Trinidad, Proc., part 12, p. 197) says that the specimens from Anguilla, which in 1866 he referred to Schizaster scille, should be referred to the species which Cotteau describes as Schizaster loveni, here called Paraster loveni.

Cotteau describes specimens of scilla from the "Miocene" of Cienfuegos, Cuba, where he says it is rare; Dewalque collection in Liège.

\section{Family SPATANGIDE Gray, 1825 . \\ Genus BRISSOPSIS Agassiz, 1840.}

Type species.-Brissus lyrifer Forbes, 1841, British Starfishes, p. 187.

Key to the West Indian Fossil Species of Brissopsis.

Petals not very divergent, II and IV ascending and then curving outward.

Periproct not visible from above...................... jimenoi

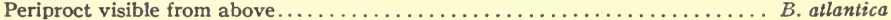

Petals markedly divergent; II and IV not curved; periproct visible from above. B. antillarum

\section{Brissopsis jimenoi Cotteau.}

Brissopsis jimenoi Cotteau, 1875, Kongl. Sven. Vet. Akad. Handl., vol. 13, No. 6, p. 6; 1881, Ann. Soc. Géol. Belgique, vol. 9, p. 33, plate 3, figs. 5 to 9; 1897, Bol. Com. Mapa Geol. España, vol. 22, p. 79, plate 24, figs. 5 to 9.

This species was described by Cotteau from the "Miocene" of Cienfuegos, San Martin, Province of Santa Clara, Cuba, where he says it is rare. Collections of Dewalque in Liége, Cotteau in Paris, and Comisión del Mapa Geológico de España, Madrid.

\section{Brissopsis atlantica Mortensen.}

Brissopsis atlantica Mortensen, 1907, Danish Ingolf Expedition, vol. 4, part 2, p. 160, plate 3, figs. 6, 10, 17. Lambert, 1915, Mém. Soc. d'Agric. de l'Aube (Troyes), vol. 79, p. 22.

This species, described by Mortensen from the living fauna, is reported by Lambert as occurring fossil in the West Indies. He says that the matrix is identical with that of Clypeaster rosaceus, which he also reports 
from Anguilla, and he attributes them both to the Pliocene(?), Anguilla, 1 specimen, collected by J.W. Gregory in 1899; British Museum.

\author{
Brissopsis antillarum Cotteau. \\ (Plate 14, Figures 3, 4.)
}

Brissopsis antillarum Cotteau, 1875, Kongl. Sven. Vet. Akad. Handl., vol. 13, No. 6, p. 37 , plate 6, figs. 19 to 25 .

The following is an extract from the original description of this species:

Species of medium size, subcordiform, a little acuminate posteriorly. Upper face moderately swollen, having its greatest height posteriorly. The posterior end is narrow and a little obliquely truncate. Lower face depressed, but having posteriorly a swelling in the plastron. The apical disk is excentric anteriorly. The anterior furrow is wide, deep, extending to the ambitus, and prolonged below as far as the peristome. The anterior ambulacrum III is straight, with very small pores disposed in oblique pairs. The paired ambulacra have the petals excavated and nearly equal, but the anterior pair II and IV are widely separated, while the posterior pair I and V are nearer together, and have a tendency to round themselves a little on each side of the summit. Poriferous areas are wide, with oblong pores, comma-like, nearly equal, scarcely open at their extremity. Interporiferous areas are very narrow, nearly wanting. Approaching the apical disk, the anterior halves of ambulacra II and IV are partly atrophied and the pores are reduced to small separated pores. [Similarly in the same region the posterior halves of ambulacra $\mathrm{I}$ and $\mathrm{V}$ are partly atrophied and the pores correspondingly reduced.] Ventrally, the ambulacral areas form wide, smooth bands; the plates are very greatly developed and the pores very widely spaced. The pores are nearer together and enlarge a little near the peristome. Tubercles are small dorsally, except at the apex and on the borders of the anterior furrow, where they are larger; they are also larger on the lower side. Peristome semicircular, excentric anteriorly, but well removed from the anterior border. Periproct rounded, opening at the summit of the posterior face. There are 4 genital pores; the anterior pair 2 and 3 are nearer together than are the posterior pair 1 and 4 . Peripetalous and subanal fascioles are narrow, sinuous, and perfectly distinct.

Height, $20 \mathrm{~mm}$., length, $47 \mathrm{~mm}$., width, $38 \mathrm{~mm}$. This is the measurement of the largest of 3 specimens in Washington; it is somewhat depressed, so that if not depressed, it would be a little higher. The best preserved specimen is somewhat smaller and measures $20 \mathrm{~mm}$. in height, $43.5 \mathrm{~mm}$. in length, and $36 \mathrm{~mm}$. in width. A young specimen which is finely preserved measures $7 \mathrm{~mm}$. in height, $14 \mathrm{~mm}$. in length, and 11.5 $\mathrm{mm}$. in width. All the evidence is that this young one and the largest one are the specimens which were figured by Cotteau. This species differs from $B$. jimenoi and atlantica, the only other West Indian fossil species of the genus, in that the anterior paired ambulacral petals are more divergent and not curved in antillarum. Cotteau cites differences between antillarum and a number of European species.

Oligocene, Anguilla formation, island of Anguilla, Guppy collection ex Cleve, 3 specimens, cotypes, the originals of Cotteau's plate 6, figures 19 to 25, U. S. Nat. Mus. No. 115406. Crocus Bay, southwest side, 
Anguilla, T. W. Vaughan collector, 2 specimens, U. S. Geol. Sur. station 6894. Crocus Bay Bluff, southwest side, uppermost horizon, 125 feet above sea-level, mostly limestone, Anguilla, T. W. Vaughan collector, 1 specimen, U. S. Geol. Sur. station 6967. Cevicos limestone, Arroyo La Mora, west of Cevicos, Dominican Republic, C. W. Cooke collector, 1 specimen, U. S. Geol. Sur. station 8599.

\section{Genus PLAGIOBRISSUS Pomel, I883.}

Type species.-Spatangus pectoralis Lamarck, 1816, Anim. sans Vert., vol. 3, p. 29-Echinus grandis Gmelin, 1788, Linné, Syst. Nat., ed. 13 , vol. 1 , part 6 , p. 3200 .

Cotteau calls his species Plagionotus loveni, but Plagionotus as a generic name is not available for Echini and Pomel's substitute Plagiobrissus must be used (see H. L. Clark, 1917, Mem. Mus. Comp. Zoöl., vol. 46, p. 207). Clark considers that the group of Echini distinguished under the name Plagiobrissus is rightfully separated from Metalia, as it not only differs from that genus structurally, but its geographical distribution is wholly different. Metalia is an Indo-Pacific genus, while Plagiobrissus is confined to certain parts of the tropical Atlantic and the western Mediterranean. Louis Agassiz first distinguished the group, but his generic name Plagionotus being preoccupied, A. Agassiz, in the Revision, simply merged the component species with Metalia of Gray, which is the most nearly allied genus. There the matter has rested, excepting that Pomel, in his remarkable but generally ignored work, suggested the name Plagiobrissus as a substitute for the preoccupied Plagionotus.

\section{Plagiobrissus loveni (Cotteau).}

(Plate 14, Figure 5.)

Plagionotus loveni Cotteau, Kongl. Sven. Vet. Akad. Handl., vol. 13, No. 6, p. 41, plate 8 , figs. 7,8 .

The following is an extract from the original description of this species:

Species of large size, cordiform, rounded and strongly indented anteriorly, a little acuminate posteriorly. Upper face moderately swollen. Apical disk excentric anteriorly. Anterior furrow nearly wanting on approaching the apical disk; very pronounced toward the ambitus. Anterior ambulacrum III straight, with small rounded pores. The paired ambulacral petals are narrow, long, excavated, especially in the upper part, nearly superficial in approaching the ambitus. Poriferous areas are wide, with oblong transverse pores united by a furrow, alternating with small granular bands. The interporiferous areas are furnished with small tubercles, unequal in size and scattered; these areas are of nearly the same width as one of the poriferous areas. Tubercles are of two kinds, one very large, crenulate, and perforate, surrounded by a large scrobicule, unequal and scattered; these occupy a large part of the dorsal region, descending nearly to the ambitus, but clearly limited by the peripetalous fasciole. The other kind of tubercles are much smaller, crowded, and very abundant, filling the spaces between the large tubercles. Below the peripetalous fasciole and as far as the ambitus these smaller tubercles are very fine, crowded, per- 
fectly homogeneous, and form small subconcentric and interrupted ranges, quite regular. The apical disk is granular, with 4 genital pores; the two anterior pores 2 and 3 are less open and are nearer together than are the two posterior pores 1 and 4. The peripetalous fasciole is wide, distinct, not sinuous, relatively very near the ambitus, subanal fasciole annular.

I did not take any measurement of the height, but it is very low. Cotteau says it is $35 \mathrm{~mm}$. in height. The length is approximately $110 \mathrm{~mm}$. and the width $100 \mathrm{~mm}$.

There is only one specimen in Washington, and Cotteau does not mention any other, merely saying that it is very rare. It is beautifully preserved in part, but very incomplete. Ambulacrum $\mathrm{V}$ is finely preserved and also interambulacra 4 and 5 , with the indication of the periproct on the right side of the posterior face. It does not make any near approach to any Recent species of the genus.

Eocene, St. Bartholomew limestone, St. Bartholomew, Guppy collection ex Cleve, 1 specimen, holotype, U. S. Nat. Mus. No. 115370.

\section{Genus MACROPNEUSTES Agassiz, 1847.}

Type species.-Macropneustes deshayesi Agassiz, 1847, Catalogue Raisonné, Ann. Sci. Nat., ser. 3, vol. 8, p. 8.

Cotteau's genus Peripneustes is not recognized by authorities and is considered purely a synonym of Macropneustes, which indeed Cotteau himself recognized, for the species here considered he put in the genus Macropneustes in his Spanish report, 1897.

Key to West Indian Fossil Species of Macropneustes.

Petals II and IV straight; test widest across apical system.................. clevei Petals II and IV curved; test widest well back of apical system............ Mntillarum

\section{Macropneustes clevei (Cotteau).}

(Plate 14, Figures 6, 7.)

Peripneustes clevei Cotteau, 1875, Kongl. Sven. Vet. Akad. Handl., vol. 13, No. 6, p. 40, plate 7, figs. 4 to 7 .

Macropneusles clevei Guppy, 1882, Scientific Assoc. Trinidad, Proc., part 12, p. 198. Cotteau, 1897, Bol. Com. Mapa Geol. España, vol. 22, p. 93, plate 28, figs. 1 to 4.

The following is an extract from the original description of this species: Species of medium size, elongate, subcordiform, expanded anteriorly, acuminate posteriorly. Upper face swollen, inclined on the sides. Subcarinate posteriorly, having its greatest height a little posterior to the apical disk. Posterior face truncate subvertically, a little reëntrant. Lower face swollen, rounded on the sides, depressed in front of the peristome and marked by an elevation of the plastron. Apical disk excentric anteriorly. The anterior furrow is wanting at the summit, but is wide and deep, especially toward the ambitus, which it enters strongly. Anterior ambulacrum III with small pores, separated, disposed obliquely, alternating on each side with a row of small tubercles. The paired ambulacra are narrow, elongate, and quite deeply sunken, open at the tips. The anterior pair II and IV are widely divergent [at an angle of about $145^{\circ}$ to each other], 
nearly horizontal. The posterior pair I and $\mathrm{V}$ are a little longer and form an acute angle [of about $48^{\circ}$ ] posteriorly. Tubercles are abundant, fine, crowded, and homogeneous below the ambitus; larger and more widely spaced dorsally at the approach to the apical disk and completely circumscribed by the peripetalous fasciole. Ventrally, around the peristome, the tubercles are relatively larger and less numerous; they form on the plastron very regular longitudinal and radiating series. The peristome is semicircular, labiate, excentric anteriorly. Periproct oval, opening at the summit of the posterior face. The apical disk is small, with 4 genital pores; the anterior pores 2 and 3 are nearer than the posterior pores 1 and 4 . Peripetalous fasciole very sinuous, following the contour of the ambulacral petals; subanal fasciole annular.

Height $35 \mathrm{~mm}$., length $61 \mathrm{~mm}$., width $51 \mathrm{~mm}$; the width would measure a little more but for lateral compression. This species is near to $M$. antillarum, but differs from it greatly in size. $M$. clevei is also higher, more swollen, the anterior furrow nearly wanting at the summit, and the apical disk relatively farther posteriorly than it is in antillarum. The apical disk is $24 \mathrm{~mm}$. from the anterior border.

There is only one specimen in Washington, which is doubtless the original of Cotteau's figures. He says that it is very rare and does not mention other material than the Cleve collection in his 1875 memoir, but does mention other specimens of the species in his Spanish report, 1897, where he says the species occurs in Cuba.

Oligocene, Anguilla formation, island of Anguilla, Guppy collection ex Cleve, 1 specimen, holotype, U. S. Nat. Mus. No. 115410. Cotteau records the species from the "Miocene" of Cuba and says an internal mold is in the collection of the Comision del Mapa Geologico de España, Madrid.

Macropneustes antillarum (Cotteau).

(Plate 15, Figure 1.)

Peripneustes antillarum Cotteau, 1875, Kongl. Sven. Vet. Akad. Handl., vol. 13, No. 6, pp. 7. 39, plate 7, figs. 1 to 3; 1881, Ann. Soc. Géol. Belgique, vol. 9, p. 46.

Macropneustes antillarum Guppy, 1882, Scientific Assoc. Trinidad, Proc., part 12, p. 198.

Macropneustes antillarum Cotteau [by clerical error Macropneustes antillanus on his page 95]. 1897, Bol. Com. Mapa Geol. España, vol. 22, p. 95, plate 29, figs. 1 to 3.

The following is an extract from the original description of this species:

Species of very large size, elongate, subcordiform; expanded anteriorly, a little narrowed posteriorly. Upper face high and elevated anteriorly, strongly inclined posteriorly, having its greatest height a little anterior to the apical disk. Posterior face short, truncate, and slightly reëntrant. Lower face nearly flat, appearing to be a little elevated in the posterior interambulacrum, depressed in front of the peristome. Apical disk very excentric anteriorly [only about $32 \mathrm{~mm}$. from the border]. The anterior furrow beginning near the apical disk is narrow and short at its upper portion, wide and deep in approaching the ambitus, which it strongly indents. Anterior ambulacrum III with small pores widely spaced. The paired ambulacra with narrow, elongate petals are quite deeply excavated. The anterior pair II and IV are very divergent, nearly horizontal; the posterior pair $\mathrm{I}$ and $\mathrm{V}$ are a little longer and form an acute angle posteriorly. 
Cotteau says that the known specimens from St. Bartholomew are badly worn, but two from the Eocene of Cuba are perfectly preserved and aided in completing his description. Tubercles are of two kinds: The larger, which are crenulate and perforate, occur dorsally near the summit and especially anteriorly on the border of the furrow; they are everywhere very definitely limited by the peripetalous fasciole. The other tubercles are fine, crowded, homogeneous, very small, principally abundant above the ambitus and in the marginal region. The peristome is labiate, semilunar, and very excentric anteriorly. Apical disk relatively little developed; madreporite long, narrow, traversing the whole area [and, as Cotteau shows in a figure, separating the two posterior genitals 1 and 4 and oculars I and V]. There are 4 genital pores, the anterior pair are smaller and nearer together than are the posterior pair. The peripetalous fasciole is sinuous, following very closely the contour of the ambulacral petals; the subanal fasciole is doubtful.

Height $44 \mathrm{~mm}$., length $128 \mathrm{~mm}$., width $99 \mathrm{~mm}$. These measurements differ very much from Cotteau's, who says the height is $43 \mathrm{~mm}$., length $117 \mathrm{~mm}$., width $105 \mathrm{~mm}$. His measurements were doubtless taken from one of his Cuban specimens, for his published figure was from one of these, as he states.

The Washington specimen is longer and narrower than Cotteau's measurements and also than his published figure, and the apical disk is much farther forward, being about $32 \mathrm{~mm}$. from the anterior border, whereas in Cotteau's figure it is $41 \mathrm{~mm}$. from the anterior border. I think it is quite probably a distinct species, but it is so worn that surface characters are largely eroded away and it therefore seems best to leave it where Cotteau placed it. In position and shape of the ambulacra it agrees well with Cotteau's figure, and it may be merely a variant. In the Washington specimen ambulacra II and IV are at an angle of about $160^{\circ}$ to each other, and ambulacra I and V are at an acute angle of about $40^{\circ}$ to each other.

This species is distinct from others known in the genus in its great size, its elongate form, elevated anteriorly and strongly inclined posteriorly, its wide and deep anterior furrow, its paired ambulacral petals very long and deep, its small tubercles, and very sinuous peripetalous fasciole.

Eocene, St. Bartholomew limestone, St. Bartholomew, Guppy collection ex Cleve, cotype, U. S. Nat. Mus. No. 115369. Cotteau also cites specimens from the Eocene of Mantanzas, Cuba, which are cotypes and in his own collection.

Genus BRISSUS Gray, 1825 .

Type species.-Spatangus brissus Leske, 1778, Add. ad Klein, pp. $\mathrm{xx}, 182$. 


\section{Brissus brissus (Leske).}

Spatangus brissus Leske, 1778, Add. ad Klein, pp. xx, 182.

Spatangus columbaris Lamarck, 1816, Anim. sans Vert., vol 3, p. 30.

Brissus columbaris A. Agassiz, 1883, Mem. Mus. Comp. Zoöl., vol. 10, No. I, p. 93. Cotteau, 1897, Bol. Com. Mapa Geol. España, vol. 22, p. 77, plate 26, figs. 1 to 3 .

I have not seen fossil material of this species. Cotteau, in his Spanish paper, describes the species and copies some old figures of a specimen from Cuba, but without detailed locality. According to Cotteau, this species probably also occurs in Guadeloupe. Indeed, A. Agassiz lists the species as from the Pliocene of Guadeloupe. It appears evident, from his resorting to a copy for an illustration, that Cotteau had no material himself.

\section{Brissus exiguus Cotteau.}

(Plate 15, Figures 2 to 4 .)

Brissus dimidiatus Guppy (non Agassiz), 1866, Quart. Jour. Geol. Soc. London, vol. 22, p. 301. Brissus exiguus Cotteau, 1875, Kongl. Sven. Vet. Akad. Handl., vol. 13, No. 6, p. 35, plate 6 , figs. 16 to 18. Guppy, 1882, Scientific Assoc. Trinidad, Proc., part 12, p. 198; 1911, Quart. Jour. Geol. Soc. London, vol. 67, p. 685.

The following is an extract from the original description of this species:

Species of very small size, elongate, narrow and rounded anteriorly, subtruncate posteriorly. Upper face swollen, subcarinate posteriorly. Lower face regularly elevated, depressed in front of the peristome. Apical disk very excentric anteriorly. Anterior furrow wholly wanting, anterior ambulacrum III straight, elongate, narrow, with large tubercles; pores are widely separated and scarcely visible. The paired ambulacra are wide, subflexuous, very unequal; the anterior pair II and IV are nearly transverse, a little rounded at the ends, moderately excavated; the posterior pair I and V are longer, straighter, a little deeper and much less divergent. The poriferous areas are wide, with elongate, narrow, equal pores in the two half-areas approaching one another so closely as to leave no interporiferous area. Tubercles are relatively well developed dorsally on the border of ambulacrum III and near the apical disk on the interambulacral areas; fine and crowded on the marginal region; larger and more widely separated ventrally. Peristome semicircular, very excentric anteriorly. The apical disk is small, compact, granular, with only 3 genital pores in the specimen in hand; the genital pore of the madreporite appears to be atrophied. Peripetalous fasciole subflexuous, not limiting the large tubercles of the dorsal side.

Height $11 \mathrm{~mm}$., length $19 \mathrm{~mm}$., width estimated at $13 \mathrm{~mm}$. It is estimated because one side is crushed and therefore an exact measurement of the width can not be made.

This beautifully preserved specimen in Washington is the only one that Cotteau had, as he states. It is therefore a holotype and the original of his figures. The ambulacral petals II and IV, which measure $5 \mathrm{~mm}$. in length each, are at right angles to the long axis and, except for the slight forward curvature, are almost in a straight line, making practically an angle of $180^{\circ}$ with each other; petals I and V are a little longer, measuring $7 \mathrm{~mm}$. each; they extend back, forming an acute angle of about $40^{\circ}$ posteriorly. The absence of a genital pore in the madreporite, as noted 
above, is obviously an abnormal feature, as 4 pores are the typical generic character; the absence of a genital pore in Recent Echini is not a very rare occurrence, as I have elsewhere noted (Phylogeny of the Echini, p. 170).

Another specimen in the Guppy collection at Washington (my plate 15, fig. 4) is larger than the one that Cotteau described. It measures $17 \mathrm{~mm}$. in height, $34 \mathrm{~mm}$. in length, and $23 \mathrm{~mm}$. in width. This specimen is much broader anteriorly than the type, but otherwise has the essential species characters. As it is nearly twice as large as the type, possibly this change in shape may be a matter of development, or it may be a variation. The shape would be apparently the only feature of difference. Cotteau says that having only one small specimen to represent this species, it may be that it is the young of some larger one not yet known. It differs from the Recent West Indian species Brissus unicola Leske by being longer and narrower, dorsally more carinate at the posterior end, and by the closeness of the poriferous areas of the paired ambulacra, which do not have any appreciable intermediate area.

Oligocene, Anguilla formation, island of Anguilla, Guppy collection ex Cleve, 1 specimen, holotype, U. S. Nat. Mus. No. 115396. Anguilla, Guppy collection, 2 specimens, U. S. Nat. Mus. No. 115378. Evidently these last are the specimens referred to by Guppy in his Trinidad paper as "the examples of this species recorded by me in $1866 \ldots$. . as dimidiatus ..... were much larger and in better preservation than the single specimen of the Cleve collection." Guppy in 1911 notes that Brissus exiguus has lately been obtained from "Miocene" [Oligocene] beds in Trinidad associated with the characteristic fossils of that formation.

Genus EUPATAGUS Agassiz, r847.

Type species.-Eupatagus valenciennesii Agassiz, 1847, Catalogue Raisonné, Ann. Sci. Nat., ser. 3, vol. 8, p. 9.

This is Cotteau's Euspatangus, an emended spelling. The West Indian fossil species of Eupatagus are very different from the single Recent species from Australia. They are readily distinguished from each other, as follows:

Key to the West Indian Fossil Species of Eupatagus.

A. Apical system only a little excentric anteriorly; petals II and IV widely divergent, but not nearly at right angles to long axis of test.

B. Petals II and IV half as wide as long; their interporiferous areas labout 60 per cent. of their width.............................. grandiflorus

BB. Petals II and IV not nearly half as wide as long; their interporiferous areas

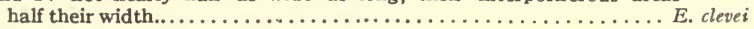

AA. Apical system very markedly anterior; petals II and IV nearly at right angles to long axis of the test.

C. Petals relatively short, so that intrafasciolar area does not cover most of abactinal surface; petals II and IV not curved.

D. Interporiferous area of petals (especially of $\mathrm{I}$ and $\mathrm{V}$ ) widest at middle or distally......................................... E. 
DD. Interporiferous areas widest proximally; poriferous areas curved....... E. depressus CC. Petals very long, nearly or quite reaching ambitus, so that intrafasciolar area covers all of abactinal surface.

E. Width exceeds length

EE. Length exceeds width.

F. Test high and narrow (height much more than half the length; width about 80 per cent. of length); petals II and IV straight....E. cubensis

FF. Test low and wide (height less than half the length; width about 90 per cent. of length); petals II and IV curved forward.

G. Test widest anteriorly; peristome little sunken $\ldots \ldots \ldots \ldots \ldots$ E. elegans

GG. Test widest posteriorly; peristome deeply sunken.......... E. vaughani

\section{Eupatagus grandiflorus (Cotteau).}

(Plate 15, Figures 5, 6.)

Euspatangus grandiflorus Cotteau, 1875, Kongl. Sven. Vet. Akad. Handl., vol. 13, No. 6, p. 45 , plate 8 , figs. 5,6 .

Eupatagus clevei Guppy (pars), 1882, Scientific Assoc. Trinidad, Proc., part 12, p. 199.

The following is an extract from the original description of this species:

Species of large size, elongate, a little contracted anteriorly; dorsally high, thick, and swollen; slightly carinate posteriorly; ventrally nearly flat. Apical disk excentric anteriorly. Anterior furrow wanting near the apical disk, more pronounced as it approaches the border, entering the ambitus strongly. Anterior ambulacrum III straight, narrow, and long, with very small pores, separated widely and scarcely visible. The paired ambulacra petaloid, very wide, nearly closed at their tips, and unequal. The anterior pair II and IV is a little arcuate in approaching the apical disk. [They are widely separate, presenting an angle of about $140^{\circ}$ to each other.] The posterior pair I and V is just a little longer, less divergent, and forming an acute angle [of about $55^{\circ}$ ] posteriorly. Poriferous areas are wide, slightly sunken; the pores are rounded and very open, united by a furrow. [Interporiferous area very wide.] In the ambulacra II and IV, the anterior poriferous area is very rounded and the pores become very small in approaching the apex. The tubercles are of two kinds, as in all species of the genus; the larger scattered, less developed than they are ordinarily, and some are preserved in the posterior interambulacrum; the other kind of tubercles are small, crowded, and homogeneous. Peripetalous fasciole nonsinuous, the rest scarcely visible.

Height $42 \mathrm{~mm}$., length $74 \mathrm{~mm}$.; as the specimen is wanting posteriorly, this measurement is inadequate; if complete, it would doubtless be from 3 to $5 \mathrm{~mm}$. longer; the width is $64 \mathrm{~mm}$.

Cotteau says that he had only a single specimen, which was from the Cleve collection. It is very much worn and shows very little of the surface characters, yet shows the petaloid ambulacra very well. Ambulacrum III is very narrow; the anterior paired ambulacra II and IV are very wide, $14 \mathrm{~mm}$.; the posterior ambulacra $\mathrm{I}$ and $\mathrm{V}$ are a trifle narrower, measuring $13 \mathrm{~mm}$. in width. This species is to be recognized from others by its size, shape, the anterior furrow, well marked at the ambitus, and especially by the width of the paired ambulacral areas, which is a striking character.

Eocene, St. Bartholomew limestone, St. Bartholomew, Guppy collection ex Cleve, 1 specimen, holotype, U. S. Nat. Mus. No. 115371. 


\section{Eupatagus species a.}

The following is a description of the specimen:

Species of large size, rounded, dome-shaped; a little narrower anteriorly than posteriorly. Anterior furrow wanting dorsally, clearly marked as a broad, shallow furrow on approaching the ambitus. Ambitus below the midzone. Rounded on the border, ventrally sunken around the peristome. Apical disk anterior, $32 \mathrm{~mm}$. from the anterior border and $65 \mathrm{~mm}$. from the posterior border of the test. Anterior ambulacrum straight and narrow, flush dorsally, lying in the shallow furrow toward the ambitus. The paired ambulacra are petaloid, of moderate width, slightly sunken. Ambulacra II and IV widely divergent, at an angle of about $155^{\circ}$ to each other. The posterior pair I and $\mathrm{V}$ form an acute angle of about $50^{\circ}$ posteriorly. Poriferous areas are wide, the pores elongate, comma-shaped, and united by a furrow. Interporiferous area about the width of a poriferous. The ambulacra are too incomplete for a full description. Larger tubercles are scattered thickly over the surface of the test; the smaller abundantly fill the spaces between the larger tubercles, but are visible only in favored spots. The peristome is anterior, but details are not visible. The periproct and details of the apical disk and fascioles are wanting.

Height $50 \mathrm{~mm}$., length $97 \mathrm{~mm}$., width $85 \mathrm{~mm}$. This species resembles E. grandiflorus, but differs in that the ambulacral petals are very much narrower and the apical disk is farther anterior. The paired petals are of about the same width as are those of $E$. clevei, but petals II and IV are much more divergent. Coming from Jamaica, from which island only a few fossil Echini are at present known, the specimen has a considerable interest. It came in the same lot with the same lithological facies as the Cidaris foveata, sp. nov., and Echinolampas ovumserpentis as here described.

Eocene, probably from the Cambridge formation of R. T. Hill, Jamaica, no detailed locality; 1 specimen, Mus. Comp. Zoöl. No. 3237.

\section{Eupatagus clevei (Cotteau).}

(Plate 16, Figures 1, 2.)

Euspatangus clevei Cotteau, 1875, Kongl. Sven. Vet. Akad. Handl., vol. 6, No. 6, p. 44, plate 8 , figs. 1 to 4 .

Eupatagus clevei Guppy (pars), 1882, Sci. Assoc. Trinidad, Proc., part 12, p. 199.

The following is an extract from the original description of this species:

Species of medium size, elongate, rounded, and a little expanded anteriorly; more narrow and truncate posteriorly; thick dorsally, swollen, a little inclined anteriorly; high and subcarinate posteriorly. Ventrally nearly flat, a little depressed anteriorly, presenting a slight elevation in the posterior interambulacrum. Apical disk excentric anteriorly. Anterior furrow very attenuate, nearly wanting. Anterior ambulacrum III straight, narrow, long, with small pores scarcely visible. The paired ambulacra are wide, petaloid, subflexuous, closed at their tips and unequal. The anterior pair II and IV are widely divergent, but are not transverse, a little arcuate; the posterior pair I and V are longer than the others, forming between them an acute angle posteriorly. Poriferous areas are wide, a little depressed, with pores rounded, very open, and united by an oblique 
furrow. Tubercles are abundant, very unequal, moderately developed, nearly as numerous in the posterior interambulacrum as in the other areas and circumscribed by the peripetalous fasciole. Ordinary tubercles are abundant and crowded toward the ambitus in the inframarginal region and on the ventral swelling of the posterior interambulacrum. They are a little more widely spaced on the approach to the peristome, leaving wholly smooth the ventral area of the posterior ambulacra I and V. Peristome narrow, sublabiate, transversely elongate, excentric anteriorly. Periproct oval, opening at the summit of the posterior face. The apical disk is narrow, compact, granular, and remarkable for the development of the madreporite which traverses the length of the disk, and in Cotteau's figure it is seen to separate the posterior genitals 1 and 4 and oculars I and V. Four genital pores, the two anterior ( 2 and 3 ) are nearer and less open than are the two posterior (1 and 4). Peripetalous and subanal fascioles non-sinuous.

Height $34 \mathrm{~mm}$., length $61 \mathrm{~mm}$., width $48 \mathrm{~mm}$. The Washington specimen is much worn anteriorly and shows little detail anterior to the apical disk. This species is distinguished from $E$. antillarum by its larger size, by the fact that it is very broadly rounded anteriorly, is proportionately wider; is more elevated and subcarinate posteriorly; the anterior paired ambulacra as far as made out (petal II is preserved in part, but petal IV is completely obliterated, as is also the anterior petal III), are wider and less divergent, in place of being nearly horizontal, as they are in antillarum. Ambulacra II and IV present an angle of about $125^{\circ}$ to each other, and the posterior pair I and V make an acute angle of about $65^{\circ}$ to each other. The peristome is transversely elongate, instead of being nearly round as in antillarum.

Cotteau says that this species is rare and mentions only the Cleve collection. It is probable that the Washington specimen was the only one that he had, as it agrees well with his measurements, and while it does not show all the details of his figures, it has nothing discordant with them.

Eocene, from the St. Bartholomew limestone, St. Bartholomew, Guppy collection ex Cleve, 1 specimen, apparently the holotype, U. S. Nat. Mus. No. 115379.

Eupatagus antillarum (Cotteau).

(Plate 16, Figures 3 to 6.)

Euspatangus antillarum Cotteau, 1875, Kongl. Sven. Vet. Akad. Handl., vol. 13, No. 6, p. 43 , plate 7 , figs. 8 to 12 .

Eupatagus antillarum Guppy, 1882, Sci. Assoc. Trinidad, Proc., part 12, p. 199.

The following is an extract from the original description of this species:

Species of small size, rounded and subdilated anteriorly; narrower and truncate posteriorly; a little swollen dorsally, thick on the borders. Lower face nearly flat, marked with an elevation corresponding to the posterior interambulacrum, which is prominent and subangular. Apical disk very excentric anteriorly. Anterior furrow very attenuated, nearly wanting. Anterior ambulacrum III narrow, long, and straight, with very small pores scarcely visible. The paired ambulacral petals are closed at their tips, very unequal; the anterior II and IV transverse [at an angle of about 
$150^{\circ}$ to each other]; the posterior $\mathrm{I}$ and $\mathrm{V}$ longer, very arcuate, forming between them an acute angle [of about $55^{\circ}$ ] posteriorly. Poriferous areas are wide, depressed, with rounded, very open pores, united by a furrow and strongly channeled. Tubercles are of two kinds; the larger are mediumsized, unequal, scrobiculate, irregularly disposed, and circumscribed by the peripetalous fasciole. These tubercles are less abundant and smaller in the posterior interambulacrum. The smaller tubercles are crowded and abundant, very fine above the ambitus, a little larger inframarginally and on the elevation of the posterior interambulacrum ventrally. They are more widely spaced toward the peristome and on the ventral surface leave nearly smooth the areas of the posterior ambulacra. The peristome is subcircular, a little elongated, excentric anteriorly. The periproct is oval, opening at the summit of the posterior face. The peripetalous and the anal fascioles are observable only at some points. They appear to be very little sinuous.

There are 2 specimens in the U. S. National Museum. The larger measures $18 \mathrm{~mm}$. in height, $47 \mathrm{~mm}$. in length, and $33 \mathrm{~mm}$. in width; the smaller specimen measures $17 \mathrm{~mm}$. in height, $38 \mathrm{~mm}$. in length, and 31 $\mathrm{mm}$. in width. The smaller specimen (my plate 16 , figs. 5 and 6 ) is the better preserved of the two and more closely agrees with Cotteau's specific description. It is apparently the original of his plate 7, figures 8 to $11 .^{1}$ This specimen is broadly rounded anteriorly, presenting one nearly continuous curve from one side around the border to the other; posteriorly it is much narrower and truncate. The larger specimen (my plate 16, figs. 3 and 4), which is apparently the original of Cotteau's plate 7 , figure 12 , is in shape almost the exact reverse of the small specimen. It is narrowly rounded and truncate anteriorly and broadly rounded posteriorly, presenting one nearly continuous curve from one side around the border to the other side. The test is widest distinctly posterior to the middle. The anterior petals II and IV are markedly wider than the same petals of the smaller specimen and the petals of the posterior ambulacra curve outward, not inward, as they do in the smaller specimen. These differences may be only a matter of variation, but this large specimen is probably a distinct species. As I have noted these characters mainly on the photographs and have not the specimens before me, I hesitate to describe it as a new species and therefore leave it where Cotteau placed it, under antillarum:

The small size, ovate or obovate form, and almost perfectly transverse anterior pair of ambulacra distinguish this species from other West Indian fossil species of Eupatagus.

Eocene, St. Bartholomew limestone, St. Bartholomew, Guppy collection ex Cleve, 2 specimens, cotypes, U.S. Nat. Mus. No.115395. Besides the Cleve collection, Cotteau mentions having specimens from the museums of Stockholm and Upsala.

${ }^{1}$ By clerical error, Cotteau, in his text (p. 43), refers this species to plate 7 , figures 7 to 11 , which should read, figures 8 to 12 . Similarly, in his description of the figures, each figure referred to is one number too low; figure 7 , side view, should read, figure 8 , side view, etc. The legend on the plate is correct. 
Eupatagus depressus, new species.

(Plate 16, Figure 7.)

\section{The following is a description of this species:}

Test subcordiform, broadly rounded anteriorly; narrower posteriorly; very low dorsally, curving very gently from the highest point at the apical disk to the relatively high rounded border on all sides; ventrally it is very nearly flat as far as preserved, but wanting in part posteriorly. Anterior furrow very slight, deepening and widening as it approaches the ambitus. Anterior ambulacrum III narrow, $2.5 \mathrm{~mm}$. wide at halfway from the apical disk to the border, with small pores, widely spaced and inconspicuous. Petals of the paired ambulacra slightly raised, narrow, curved, pointed, nearly closed at the tips. The anterior pair II and IV is widely divergent, but not transverse, at an angle of about $140^{\circ}$ to each other, $21 \mathrm{~mm}$. long, curving gently anteriorly; the posterior pair I and V (ambulacrum V is wanting, but the suture of its contact with interambulacrum 4 exists, thus indicating its contour on that side) is longer, $28 \mathrm{~mm}$. in length, curving outward and forming an acute angle of about $60^{\circ}$ to each other posteriorly. Poriferous areas are narrow, sunken, with nearly round medium-sized pores connected by a deep, strongly marked furrow. Tubercles are of two kinds. The larger are very large, with strongly marked scrobicules, they are widely spaced on the four anterior interambulacra dorsally, but are wanting on interambulacrum 5, and are circumscribed by the peripetalous fasciole. Ventrally, these primary tubercles are crowded near the border; for the rest of the ventral area they are abundant but more widely spaced. The ventral side is too imperfect, or in part wanting, to show much detail. Small tubercles are crowded and occupy the spaces between the large tubercles and alone exist on the ambulacral areas and on the posterior interambulacrum 5 dorsally. Peristome obscurely outlined, but wide and excentric anteriorly, $24 \mathrm{~mm}$. from the anterior border. Periproct wanting, apical disk excentric anteriorly, $27 \mathrm{~mm}$. from the anterior border; it is very small, and imperfect from a local fracture, but the madreporite with its large pore is preserved. The peripetalous fasciole is obscurely marked, following the outline of the petals; the subanal fasciole is wanting, as the test is largely broken away at that area.

Height $13 \mathrm{~mm}$., length about $65 \mathrm{~mm}$., width $60 \mathrm{~mm}$. This species is characterized by its very low, flat form, yet, with high rounded border and curving narrow ambulacra, is radically different from any other fossil West Indian species of the genus. It approaches nearest to Eupatagus carolinensis IV. B. Clark, ${ }^{1}$ but is much larger and flatter, with a distinct anterior sinus which is quite wanting in carolinensis.

Oligocene, high bluff, $2 \mathrm{~km}$. southwest of Juana Diaz, Porto Rico, from huge blocks of fallen limestone where irrigation flume is covered with earth, 1 specimen the holotype, station 199, American Mus. Nat. Hist. No. 18573, C. A. Reeds collector, under auspices of the New York Academy of Sciences, the Porto Rican Government and the American Museum of Natural History coöperating.

1 Clark and Twitchell, 1915, Monograph, U. S. Geol. Sur., p. 153, plate 71, figs. $3 a$ to $3 d, 4$. 


\section{Eupatagus abruptus (Gregory).}

Archcoopneustes abruptus Gregory, 1892, Quart. Jour. Geol. Soc. London, vol. 48, p. 163. plate 4 , figs. 1 to 5 .

Asterostoma, sp. nov. Gregory, 1892, Bull. Geol. Soc. Amer., vol. 3, p. 107 [errata p. xil says, for Asterostoma, n. sp. read Archoopreuster abruptus Greg.].

This species belongs to Eupatagus rather than Archcopneustes because of its close relationship to Eupatagus cubensis (Cotteau). It has no near relationship to Palceopneustes hystrix A. Agassiz, which Recent species Gregory made the type of his genus Archceopneustes. Gregory does not give a geological age to this species in his description, but in a later paper (1895, Quart. Jour. Geol. Soc., vol. 51, pp. 255 to 312) says that the Oceanic series is younger than the Scotland beds. R. J. L. Guppy ${ }^{1}$ reports finding Echinolampas anguilla in the bed whence this species came. The age of the deposit, the Bissex Hill formation, would therefore be Oligocene, either the Antiguan or the Anguillan horizon. For a new Eupatagus from Barbados, recently received by the U. S. National Museum, see p. 3.

Oligocene, uppermost limestone of the Oceanic series, Bissex Hill "beds," Barbados, G. Firth Franks collector; type, British Museum, No. E 3433.

\section{Eupatagus cubensis (Cotteau).}

Macropneustes cubensis (Cotteau), 1875, Kongl. Sven. Vet. Akad. Handl., vol. 13, No. 6, p. 6; 1881, Ann. Soc. Géol. Belgique, vol. 9, p. 48, plate 4, fig. 7; 1897, Bol. Com. Mapa Geol. España, vol. 22, p. 91, plate 23, figs. 1 to 4; plate 25, fig. 7.

I have not seen specimens of this species. It belongs in the genus Eupatagus rather than Macropneustes, because the ambulacral petals are flush, not sunken. Cotteau describes the species from the Eocene of St. Martin, Province of Matanzas, Cuba, Cotteau collection, Paris; also ingenio Constancia, in the Province of Santa Clara, Cuba, collection Comisión del Mapa Geológico de España, Madrid.

Eupatagus elegans, new species.

(Plate 16, Figure 8; Plate 17, Figure 1.)

The following is a description of this species:

Species of large size, ovate in outline, broadly rounded anteriorly, narrower and almost coming to a point posteriorly. Upper face subconical, the apex coinciding with the apical disk, which is excentric anteriorly. From the apex the test slopes quite steeply anteriorly and more gradually posteriorly and laterally to the ambitus. It is rounded quite sharply at the ambitus. The ventral side is depressed about the peristome and rises in a prominent elevation in the plastron, especially posteriorly. This swelling, while marked, is not as excessive as it is in the next species, $E$. vaughani. There is a slight depression anteriorly in which the ambulacrum III lies, which could hardly be called a furrow. The paired ambulacra all lie in radial slight depressions of the test. The anterior ambulacrum III is straight, narrow, with small pores situated in the lower half of the plates. The paired ambulacra are rather narrow for the size of the specimen (13 mm. at the widest part), petaloid, widening markedly below the petals, widest at the ambitus, thence narrowing to the peristomal border. Ambulacra II and IV, the anterior pair, are widely divergent, almost at right 
angles to the long axis, lying at an angle of about $160^{\circ}$ to each other. The posterior pair I and V converge strongly, forming an acute angle of about $65^{\circ}$ posteriorly. Poriferous areas are narrow, the outer pores elongate, oblique; the inner slightly oval. The interporiferous areas are narrow; near the peristome the pores are close together and situated near the lower border of each plate. Interambulacra are broad, the lower border of the plates being markedly curved. Plastron long, rather narrow, and it, with the adjacent ambulacra I and V, is moderately but distinctly elevated. The primary tubercles are small, perforate, crenulate, and scrobiculate; scattered on the dorsal surface, more crowded toward the ambitus and ventrally. Small granules are scattered abundantly between the primary tubercles and form rings around the latter. A few spines are preserved in protected spots; these spines are slender and acicular, and the best preserved measure about $5 \mathrm{~mm}$. in length. The apical disk is very small, with 4 genital plates having extra large genital pores; the pores of genitals 2 and 3 are nearer together than are those of 1 and 4 . The madreporite extends back, separating the posterior genitals and oculars. Oculars are very small. The peristome is situated anteriorly, but at a considerable distance $(30 \mathrm{~mm}$.) from the anterior border; it is in a moderate depression, transversely elongate, labiate. The periproct is not clearly outlined in any of the specimens, but it is large, oval in the vertical plane, and situated on the posterior face, not visible from above.

This species is represented by several finely preserved specimens. The holotype (plate 17, fig. 1), which is the most complete dorsally, measures about $43 \mathrm{~mm}$. in height, $119 \mathrm{~mm}$. in length, and $108 \mathrm{~mm}$. in width across ambulacra II and IV, which is the widest part of the test. The paratype (plate 16, fig. 8), which is a little smaller than the holotype, measures $41 \mathrm{~mm}$. in height, $110 \mathrm{~mm}$. in length, and $100 \mathrm{~mm}$. in width. It is extremely well preserved ventrally and in part dorsally.

The two described specimens are light gray. A third individual from the same locality but from yellowish shales, which color the specimen has, is referred to this species with some doubt. It is well preserved, but is very imperfect dorsally. It has the same form in outline as the type, but is very much flattened. The plastron is much narrower anteriorly and wider posteriorly. My impression is that it belongs to a distinct and new species, but it has not sufficient structure preserved for a proper description. It is interesting that some spines are associated with specimens of this species. This is the only species of West Indian fossil Echini, other than the species of Cidaris, of which I have seen the spines, and they have not been reported in any other species as far as known. The large size, conical form, and the great width anteriorly and narrowness posteriorly distinguish this species from any other West Indian or American species of the genus.

Oligocene, high bluff, $2 \mathrm{~km}$. southwest of Juana Diaz, Porto Rico, from huge block of limestone, halfway up slope and just beneath basal limestone ledge, in situ, 1 specimen, the holotype, station 196, American Mus. Nat. Hist. No. 18574 . High bluff, $2 \mathrm{~km}$. southwest of Juana Diaz, Porto Rico, greenish to yellowish shales (Juana Diaz), exposed in the west 
bank of the Jacaguas River, 1 specimen, paratype (also a fragment, both olive gray), station 188, American Mus. Nat. Hist. No. 18575. Same locality and data; 1 specimen, which is referred doubtfully to this species, station 189. All of the above specimens of this species were collected by C. A. Reeds under the auspices of the New York Academy of Sciences, the Porto Rican Government and the American Museum of Natural History coöperating.

\section{Eupatagus vaughani, new species.}

(Plate 17, Figure 2; Plate 18, Figures 1, 2.)

\section{The following is a description of this species:}

Test massive, oval, elongate, a little contracted anteriorly; low, rounded, dome-shaped dorsally, presenting almost an equal curve anteroposteriorly, but is a little steeper anteriorly; strongly rounded on the border, especially posteriorly. Posteriorly, rising in a rounded outline rather than a steep face. Ventrally, nearly flat on the marginal outline, hollowed into the anterior peristome. The plastron is elevated strongly, and posteriorly it presents almost a median ridge. The anterior furrow is wanting, except ventrally, close to the peristome. Ambulacra flush, wide, petaloid, curved, excepting ambulacrum III, which is narrow, straight, inconspicuous, widening as it approaches the peristome. The pores of ambulacrum III can not be made out dorsally, as the specimen is much worn, but ventrally they appear as single pores in a furrow, which widens as it approaches the peristome. The paired ambulacra are wide, petaloid, curving, the petals extending to the ambitus. The anterior pair II and IV are widely diverging, at an angle of about $145^{\circ}$ to each other, curving forward as they approach the ambitus; the posterior pair I and V are a little wider than II and IV, much less diverging, and present an acute angle of about $60^{\circ}$ posteriorly; they are only slightly curved. The pores of the paired areas are very much alike, rounded, and prominent; the inner and outer pores are in a straight line, separated by a moderately short space, and situated on the outer border of the plates; the interporiferous area is narrow. The interambulacra are wide and the plates are strongly curved on the horizontal suture lines. The details of plate-sutures and tubercles are almost gone from mechanical wear of the surface in the holotype, but in the second specimen or paratype the sutures are quite obvious and a few tubercles are preserved. These tubercles are small, perforate, scrobiculate, not crowded. The apical disk is small, excentric anteriorly, but no details of the plates are preserved. The peristome is transversely elongate, labiate, excentric, quite near the anterior border of the test. The periproct is very large $(23 \mathrm{~mm}$. high, 19 mm. wide), oval in a vertical plane, situated on the posterior face and just barely visible from above. The plastron is very large, triangular, wide and strongly elevated posteriorly, so much so that this area stands out as a distinct bulge below the ambital outline when seen in profile. Fascioles are not preserved in either specimen.

The holotype, which is the more complete of the two known specimens, measures $50 \mathrm{~mm}$. in height through the plane of apical disk, $134 \mathrm{~mm}$. in length, and $118 \mathrm{~mm}$. in greatest width through interambulacra 1 and 4 . 
This fine species by far surpasses in size any other West Indian species of the genus and makes no close approach to any of them. It is clearly characterized by its great size, low, rounded dorsal outline, and the great swelling ventrally of interambulacrum 5 near the posterior border of the test. While the holotype is the more perfect specimen as a whole, the second specimen, or paratype, shows interambulacral suture lines and in protected spots very well preserved tubercles. I take great pleasure in naming this species for Dr. T. Wayland Vaughan, who has done so much to elucidate the geology and palæontology of the West Indies.

Oligocene, Antigua formation, bluff on north side of Willoughby Bay, Antigua; T. IV. Vaughan collector, 1914; U. S. Geol. Sur. station 6881; 2 specimens, the holotype, U.S. Nat. Mus. No. 328245; and a paratype, U.S. Nat. Mus. No. 328246.

Eupatagus species b.

This species is represented by a single specimen, too incomplete for description, but representing a very large species distinct from others known, but nearest to Eupatagus vaughani. The test is elongate, very low and wide. The apical disk is posterior to the center, being about $90 \mathrm{~mm}$. from the anterior border. Petals II and IV are widely divergent; petals I and $\mathrm{V}$ are sunken, and present an acute angle posteriorly. The outer pores are elongate, oval, the inner pores rounded, the pores of each pair being connected by a furrow. The interporiferous area is twice the width of a poriferous area. The width of petal I at its widest part is $22 \mathrm{~mm}$., and of petal IV is about $20 \mathrm{~mm}$. Ambulacrum III is imperfectly visible in part, but it is apparently flush, straight, and much narrower than the other ambulacral areas.

The specimen is about $145 \mathrm{~mm}$. in length and about $130 \mathrm{~mm}$. in width; it is very low, but the height is unknown, as the specimen is too incomplete to allow any accurate vertical measurement. It is a pity that it is not better preserved, as it represents a fine and very large species.

Eocene, St. Bartholomew limestone, Governor's Bay, point between the bay and Grand or Négre Point, St. Bartholomew, 1 specimen, T. W. Vaughan collector, 1914; U. S. Geol. Sur. station 6921; U. S. Nat. Mus. No. 328224 .

\section{Genus BREYNIA Desor, 1847 .}

Type species.-Spatangus crux-andrece Lamarck, 1816, Anim. sans Vert., vol. 3, p. $31=$ Spatangus australasice Leach, 1815, Zoöl. Misc., vol. 2 , p. 68 , plate 82 .

\section{Breynia cubensis Cotteau.}

Breynia cubensis Cotteau, 1875, Kongl. Sven. Vet. Akad. Handl., vol. 13, No. 6, p. 7; Ann. Soc. Géol. Belgique, vol. 9, p. 43, plate 4 , figs. 4 to $6 ; 1897$, Bol. Com. Mapa Geol. España, vol. 22, p. 87 , plate 25 , figs. 4 to 6 .

The genus Breynia is an Indo-Australian type in the Recent fauna, and it is quite remarkable that a fossil West Indian species should have 
occurred. I have not seen a specimen, but Cotteau described this species from the Eocene (?) of Matanzas, Cuba. The material is in his own collection.

Lambert (1915, Mém. Soc. d'Agric. de l'Aube (Troyes), vol. 79, p. 31) claims that Cotteau's Breynia cubensis is not a true Breynia, but belongs rather with Brissoides. He notes that a specimen of the genus Brissoides was found at "Dodger's Bay," Antigua, and that it differs from cubensis in that the latter has fewer but larger tubercles, more equal petals, less tapering and non-flexuous. The specimen which Lambert describes, without specific name, is very imperfectly preserved; it was collected by J. W. Gregory, 1899, collection of British Museum.

[NoTE.-In a paper on fossil Echini from northeastern Mexico, a number of Cotteau's West Indian species are recorded as occurring in Mexico. This paper by Kew (in R. E. Dickerson and W. S. W. Kew, 1917. The fauna of a medial Tertiary formation and the associated horizons of northeastern Mexico. Proc. California Acad. Sci., ser. 4, vol. 7, pp. 125-156, pls. 17-26a) came to my attention too late to be considered otherwise than by this note. The species referred to are beautifully figured, and a locality is given but no description. What Kew calls Clypeaster cf. concavus Cotteau has petals too flaring and wide open, and the test is proportionately too wide to be closely compared to concavus. His Clypeaster cubensis Cotteau, though I have not seen specimens of the species, appears to be too flattened above the border and has petals too short proportionately to be referred to that species. His Agassizia clevei Cotteau is evidently very close to the species here (p. 70) separated from Cotteau's clevei as $A$. inflata, sp. nov. What Kew calls Schizaster clevei Cotteau differs so radically in side view from cleve $i$ that it seems it can not be referred to that species. Kew's Macropneustes antillarum Cotteau is much higher posteriorly and more rounded marginally than the only specimen of the species that I have seen. It is very doubtful if Kew's identification is correct.] 


\section{BIBLIOGRAPHY OF PRINCIPAL PUBLICATIONS ON WEST INDIAN FOSSIL ECHINI.}

Agassiz, Alexander. 1883. Reports on results of dredging . . . by U. S. Coast Survey steamer Blake. Report on the Echini, Mem. Mus. Comp. Zoöl., vol. 10, No. 1, pp. i-viii, 9-94, pls. 1-9, 9a, 10-15, 15a-15c, 16-28.

Brown, Amos P. 1914. Notes on the geology of the island of Antigua. Proc. Acad. Nat. Sci., Phila., vol. 65, pp. 584-616, pls. 18-20.

Cotteau, [Gustave Honoré]. 1871. Notice sur le genre Asterostoma. Mém. Soc. Géol. de France, ser. 2, vol. 9, pp. 177-184, pls. 16, 17.

1875. Descriptions des Echinides tertiaires des Iles St. Barthélemy et Anguilla. Kongl. Sven. Vet. Akad. Handl., vol. 13, No. 6, pp. 1-48, pls. 1-8.

1881. Description des Échinides fossiles de l'Ile de Cuba. Annales Soc. Géol. de Belgique, vol. 9, pp. 1-49, pls. 1-4.

1897. Descripción de los Equinoides Fósiles de la Isla de Cuba por M. G. Cotteau, adicionada por D. Justo Egozcue y Cia. Bol. Com. del Mapa Geol. de España, vol. 22, pp. 1-100, pls. 1-29.

DE Cortázar, D. 1880. Descripción de un nuevo Equinodermo de la Isla de Cuba: Encope cia, n. sp. Bol. Com. del Mapa Geol. de España, vol. 7, pp. 227-232 [pp. 1-6 of article], pls. $G$ and $H$.

Desor, Édouard. 1858 Synopsis des Échinides fossiles, pp. i-lxiii, 1-490, 1-44, pls. $1-44$.

Duchassaing, Pierre. 1855. Sur les formations modernes de l'île de la Guadeloupe, par M. Duchassaing, D.-M. a l'île Saint-Thomas (Antilles). Bull. Soc. Géol. de France, ser. 2, vol. 12, pp. 753-757.

Egozcue y Cia, Justo. See Cotteau, 1897.

Gregory, J. W. 1889. Cystechinus crassus, a new species from the Radiolarian marls of Barbados, and the evidence it affords as to the age and origin of these deposits. Quart. Jour. Geol. Soc. London, vol. 45, pp. 640-650, figs. 1-3.

1892. Archcopneustes abruptus, a new genus and species of echinoid from the Oceanic series in Barbados. Quart. Jour. Geol. Soc. London, vol. 48, pp. 163169 , pl. 4.

1892a. The relations of the American and European echinoid faunas. Bull. Geol. Soc. America, vol. 3, pp. 101-108. [See errata, p. xii of that volume.]

1895. Contributions to the palæontology and physical geology of the West Indies. Quart. Jour. Geol. Soc. London, vol. 51, pp. 255-312, pl. 11.

Guppy, R. J. Lechmere. 1866. On Tertiary Echinoderms from the West Indies. Quart. Jour. Geol. Soc. London, vol. 22, pp. 297-301, pl. 19.

1882. On the fossil Echinodermata of the West Indies. Scientific Assoc. Trinidad, Proc., part 12, pp. 193-199.

1911. On the geology of Antigua and other West Indian islands with reference to the physical history of the Caribbean region. Quart. Jour. Geol. Soc. London, vol. 67 , pp. $681-700$, pl. 50 [map].

Hill, Robert T. 1899. The geology and physical geography of Jamaica. Bull. Mus. Comp. Zoöl., vol. 34, pp. 1-256, pls. 1-41.

Lambert, J. 1915. Échinides Néogènes des Antilles Anglaises. Mém. Soc. Acad. d'Agriculture, des Sciences, Arts et Belles Lettres du Départment de l'Aube, Troyes, vol. 79, pp. 17-34, one plate [not numbered].

Michelin, Hardouin. 1855. Échinides vivants et fossiles des Antilles et du Golfe du Mexique. Bull. Soc. Géol. de France, ser. 2, vol. 12, pp. 758-759 [signed H. M.].

1861. Monographie des Clypéastres fossiles. Mém. Soc. Géol. de France, ser. 2, vol. 7, pp. 101-148, pls. 9-36.

[NotE.-For lists of recent papers on West Indian geology and palæontology and on Mesozoic and Tertiary Echini of the United States and Central America, see the following paper by Doctor Vaughan, pages 107, 108, and 120.] 


\section{DESCRIPTION OF PLATES.}

[The accompanying plates were made up to be reduced to a uniform width of $5 \mathrm{x} / 2$ inches. This proved to be undesirable, and the plates are reduced to 5 inches in width, with in most cases a corresponding slight reduction of the original figures. The approximate size of the figures is given in the descriptions. Where desired the exact size of specimens can usually be obtained from the descriptions in the text.]

\section{Plate 1.}

FIg. 1. Cidaris anguilla Cotteau. Cotype, $\times 3.4$; spine; Anguilla; U. S. Nat. Mus. No. 115393.

FIGS. 2-5. Cidaris peloria, sp. nov. Spines and interambulacral plate, $\times 0.9$; (2) base and shaft, holotype; (3) interambulacral plate; (4) tip of probably a ventral spine; (5) base and tip with estimated interval indicated by dotted lines; ( 3 to 5 ) paratypes; near San Sebastian, Porto Rico; Amer. Mus. Nat. Hist. No. 18564.

Figs. 6, 7. Cidaris foveala, sp. nov. Holotype, $\times 0.9$; (6) dorsal and (7) side views of the same specimen. The peculiar pits are best seen in right interambulacrum. Jamaica; Mus. Comp. Zoöl. No. 3234.

FIGs. 8-10. Cidaris loveni Cotteau. Holotype, $\times 0.9$; (8) dorsal, (9) ventral, and (10) side views of same specimen; St. Bartholomew; U. S. Nat. Mus. No. 115415.

FIG. 11. Cidaris clevei Cotteau. Holotype, $\times 4$; side view of interambulacrum and two half-ambulacra; Anguilla; U.S. Nat. Mus. No. 115400.

Figs. 12-17. Cidaris melitensis Wright. Tests and spines, $\times 0.8$; (12) dorsal, (13) ventral, and (14) side views of the same specimen; (15) spines; (16) dorsal and (17) ventral views of an immature specimen; Anguilla; U. S. Nat. Mus. No. 115399.

FIGs. 18-20. Cidaris tribuloides (Lamarck). Test, $\times 1$; (18) dorsal, (19) ventral, and (20) side views of same specimen, Santiago de Cuba; U.S. Nat. Mus. No. 328221.

Figs. 21-24. Echinometra prisca Cotteau. Cotype, $\times 1.8$; (21) dorsal, (22) ventral, (23) side view in longer axis, and (24) side view in shorter axis of same specimen; Anguilla; U. S. Nat. Mus. No. 115398.

\section{Plate 2.}

FIG. 1. Echinopedina cubensis Cotteau. Dorsal view, $\times 0.9$; Rio Gurabo, Dominican Republic; U. S. Nat. Mus. No. 328232.

Figs. 2-5. Lanieria lanieri (Cotteau). (2) Dorsal view of large specimen and (3) left side view of same specimen, $\times 0.9 ;(4)$ dorsal view of smaller specimen, $\times 1.8 ;(5)$ ventral view of another small specimen, $\times 1.8$; Cuba; Phila. Acad. Nat. Sci. No. 1505.

FIGs. 6, 7. Sismondia antillarum Cotteau. Holotype, $\times 1.8$; (6) dorsal and (7) ventral views of same specimen; St. Bartholomew; U. S. Nat. Mus. No. 115394.

FIGs. 8, 9. Sismondia anguilla Cotteau. Holotype, $\times 1.8 ;(8)$ dorsal and (9) ventral views of same specimen. The periproct is very small. Anguilla; U.S. Nat. Mus. No. 115421 .

FIGs. 10,11. Clypeaster concavus Cotteau. Cotype, $\times 0.9$; (10) dorsal and (11) ventral views of same specimen; Anguilla; U. S. Nat. Mus. No. 115376. .

FIG. 12. Clypeaster concavus Cotteau. Four-rayed specimen, $\times 0.9$; near Cevicos, Dominican Republic; U.S. Nat. Mus. No. 328233.

Plate 3.

FIGs. 1, 2. Clypeaster caudatus, sp. nov. Holotype, $\times 1$; (1) dorsal and (2) left side views of same specimen; Los Quemados, Dominican Republic; U. S. Nat. Mus. No. 328235. 
Plate 4.

FIG. 1. Clypeaster dalli (Twitchell). Dorsal view, $\times 0.7$; Gato, Dominican Republic; U. S. Nat. Mus. No. 328234 .

FIG. 2. Clypeaster lanceolatus Cotteau. Dorsal view, $\times 0.7$; Havana, Cuba; Amer. Mus. Nat. Hist. No. 18577.

Plate 5.

FIgs. 1, 2. Clypeaster antillarum Cotteau. Holotype, $\times 1$; (1) dorsal and (2) ventral views of same specimen; Anguilla; U. S. Nat. Mus. No. 115390 .

\section{Plate 6.}

Figs. 1, 2. Clypeaster planipetalus Cotteau. (1) Dorsal and (2) left side views of same specimen, $\times 0.9$; north side of Willoughby Bay, Antigua; U.S. Nat. Mus. No. 328237 .

Figs. 3-5. Clypeaster cryptopetalus, sp. nov. Holotype, $\times 0.9$; (3) dorsal, (4) ventral, and (5) left side views of same specimen; Rifle Butts, Antigua; U. S. Nat. Mus. No. 328239 .

FIgs. 6-8. Clypeaster cotteaui Egozcue. (6) Dorsal, (7) ventral, and (8) left side views of same specimen; $\times 0.9$; near Guantanamo, Cuba; C. T. Ramsden's collection.

\section{Plate 7.}

Figs. 1, 2. Clypeaster placentoides, sp. nov. The holotype is the smaller specimen resting on the dorsal side of the larger, which is the same species; $\times 0.9$; (1) dorsal and (2) left side views of same; near Guantanamo, Cuba; C. T. Ramsden's collection.

FIG. 3. Clypeaster oxybaphon, sp. nov. Paratype, $\times 0.9$; dorsal view; Guanica Harbor, Porto Rico; Amer. Mus. Nat. Hist. No. 18567.

FIG. 4. Clypeaster oxybaphon, sp. nov. Paratype, $\times 0.9$; ventral view; Guanica Harbor, Porto Rico; Amer. Mus. Nat. Hist. No. 18568.

Figs. 5, 6. Echinarachnius sebastiani, sp. nov. (5) Holotype, dorsal view; (6) paratype, dorsal view; $\times$ 0.9; San Sebastian, Porto Rico; Amer. Mus. Nat. Hist. No. 18570.

FIG. 7. Encope latus, sp. nov. Holotype; dorsal view; $\times 0.9$; the vertical axis of this figure is twisted to the left; compare text-figure 5, p. 51; Government Road, Aguadilla to Rincon, Porto Rico; Amer. Mus. Nat. Hist. No. 18572 .

\section{Plate 8.}

FIGs. 1, 2. Clypeaster oxybaphon, sp. nov. Holotype, $\times 1$; (1) dorsal and (2) left side views of same specimen; north side of Willoughby Bay, Antigua; U. S. Nat. Mus. No. 328241.

FIG. 3. Clypeaster oxybaphon, sp. nov. Paratype, $\times 1$; dorsal view, north side of Willoughby Bay, Antigua; U.S. Nat. Mus. No. 328242.

\section{Plate 9.}

FIGs. 1, 2. Clypeaster platygaster, sp. nov. Holotype, $\times 0.9$; (1) dorsal and (2) ventral views of same specimen; Havana, Cuba; Amer. Mus. Nat. Hist. No. 18569.

FIG. 3. Peronella mirabilis, sp. nov. Holotype, $\times 1.8$; dorsal view; Mount Moriah, San Fernando, Trinidad; U. S. Nat. Mus. No. 328247.

FIGs. 4, 5. Echinoneus cyclostomus Leske. (4) Dorsal and (5) ventral views of same specimen, $\times 1.8$; Anguilla; U.S. Nat. Mus. No. 115402.

Figs. 6-8. Parapygus antillarum (Cotteau). Cotype, $\times 0.9 ;(6)$ dorsal, (7) ventral, and (8) right side views of same specimen; St. Bartholomew; U. S. Nat. Mus. No. 115417.

FIG. 9. Parapygus antillarum (Cotteau). Cotype, $\times 0.9$; ventral view; St. Bartholomew; U. S. Nat. Mus. No. 115420. 


\section{PLATE 9-continued.}

Figs. 10-12. Echinolampas antillarum Cotteau. Cotype, $\times 0.9$; (10) dorsal, (11) ventral, and (12) right side views of same specimen; St. Bartholomew; U. S. Nat. Mus. No. 115401.

\section{Plate 10.}

Figs. 1-3. Echinolampas semiorbis Guppy. Cotype, $\times 0.9$; (1) dorsal, (2) ventral, and (3) anterior views of same specimen; Anguilla; U. S. Nat. Mus. No. 115386.

FIGs. 4, 5. Echinolampas ovumserpentis Guppy. Cotypes, $\times 0.9$; (4) dorsal view; (5) ventral view of another specimen; San Fernando, Trinidad; U. S. Nat. Mus. No. 115389.

FIGs. 6, 7. Echinolampas clevei Cotteau. Cotypes; $\times 0.9$; (6) dorsal view; (7) ventral view of young specimen; St. Bartholomew; U. S. Nat. Mus. No. 115419.

\section{Plate 11.}

FIgs. 1, 2. Echinolampas clevei Cotteau. Cotpye, $\times 0.9$; (1) dorsal and (2) left side views of same specimen; St. Bartholomew; U. S. Nat. Mus. No. 115374.

Figs. 3-5. Echinolampas lycopersicus Guppy. (3) Dorsal, (4) ventral, and (5) right side views of same specimen, $\times 0.9$; Anguilla; U. S. Nat. Mus. No. 115387.

FIG. 6. Echinolampas lycopersicus Guppy. Cotype, $\times 0.9$; dorsal view; Anguilla; U. S. Nat. Mus. No. 115388.

Figs. 7-9. Echinolampas anguilla Cotteau. Holotype, $\times 0.8$; (7) dorsal, (8) ventral, and (9) left side views of same specimen; Anguilla; U. S. Nat. Mus. No. 115372.

\section{Plate 12.}

FIG. 1. Cardiaster cubensis, sp. nov. Holotype, $\times 0.9$; dorsal view; valley of Rio Yateras, Cuba; C. T. Ramsden collection.

Figs. 2-4. Agassizia inflata, sp. nov. Holotype, $\times 1.8$; (2) dorsal, (3) ventral, and (4) left side views of same specimen; St. Bartholomew; U. S. Nat. Mus. No. 325610.

FIGs. 5-7. Agassizia clevei Cotteau. Cotype, $\times 1.8$; (5) dorsal, (6) ventral, and (7) left side views of same specimen; Anguilla; U.S. Nat. Mus. No. 115407.

Figs. 8, 9. Prenaster loveni Cotteau. Holotype, $\times 2$; (8) dorsal and (9) ventral views of same specimen; St. Bartholomew; U. S. Nat. Mus. No. 115411.

FIG. 10. Hemiaster berkeyi, sp. nov. Holotype, $\times 0.9$; dorsal view; Guanica, Porto Rico; G. J. Mitchell collection.

\section{Plate 13.}

Figs. 1-3. Paraster antillarum (Cotteau). Cotype, $\times 1.8$; (1) dorsal, (2) ventral, and (3) left side views of same specimen; St. Bartholomew; U. S. Nat. Mus. No. 115404

Figs. 4, 5. Paraster clevei (Cotteau). Holotype, $\times 0.9$; (4) dorsal and (5) left side views of same specimen; Anguilla; U. S. Nat. Mus. No. 115408.

Figs. 6-8. Paraster loveni (Cotteau). Cotypes, $\times 1.8$; (6) dorsal and (7) ventral views of same specimen; (8) dorsal view of another specimen; Anguilla; U. S. Nat. Mus. No. 115391.

FIG. 9. Paraster loveni (Cotteau). Cotype, $\times 0.9$; dorsal view of another specimen; Anguilla; U. S. Nat. Mus. No. 115391.

FIG. 10. Paraster subcylindricus (Cotteau). Cotype, $\times 1.8$; dorsal view; St. Bartholomew; U. S. Nat. Mus. No. 115416.

FIG. 11. Periaster elongatus Cotteau. Holotype, $\times 0.9$; dorsal view; St. Bartholomew; U. S. Nat. Mus. No. 115418. 
Plate 14.

Figs. 1, 2. Paraster subcylindricus (Cotteau). Cotype, $\times 1.8$; (1) dorsal and (2) ventral views of same specimen; St. Bartholomew; U. S. Nat. Mus. No. 115416.

Figs. 3, 4. Brissopsis antillarum Cotteau. Cotype, $\times 0.9$; $\nvdash(3)$ dorsal and (4) ventral views of same specimen; Anguilla; U.S. Nat. Mus. No. 115406.

Fig. 5. Plagiobrissus loveni (Cotteau). Holotype, $\times 0.9$; dorsal view; St. Bartholomew; U. S. Nat. Mus. No. 115370.

Figs. 6, 7. Macropneustes clevei (Cotteau). Holotype, $\times 0.9$; (6) dorsal and (7) ventral views of same specimen; Anguilla; U. S. Nat. Mus. No. 115410.

Plate 15.

Fig. 1. Macropneustes antillarum (Cotteau). Cotype, $\times 0.9$; dorsal view; St. Bartholomew; U. S. Nat. Mus. No. 115369.

Figs. 2, 3. Brissus exiguus Cotteau. Holotype, $\times 3.6$; (2) dorsal and (3) left side views of same specimen; Anguilla; U.S. Nat. Mus. No. 115396.

FIg. 4. Brissus exiguus Cotteau. Dorsal view; $\times 0.9$; Anguilla; U. S. Nat. Mus. No. 115378.

Figs. 5, 6. Eupatagus grandiflorus (Cotteau). Holotype, $\times 0.9$; (5) dorsal and (6) left side views of same specimen; St. Bartholomew; U. S. Nat. Mus. No. 115371.

Plate 16.

Figs. 1, 2. Eupatagus clevei (Cotteau). Holotype, $\times 0.9$; (1) dorsal and (2) ventral views of same specimen; St. Bartholomew; U. S. Nat. Mus. No. 115379.

Figs. 3-6. Eupatagus antillarum (Cotteau). Cotypes; $\times 0.9$; (3) dorsal and (4) ventral views of same specimen; (5) another specimen, dorsal view, and (6) ventral view of the same; St. Bartholomew; U. S. Nat. Mus. No. 115395.

FIG. 7. Eupatagus depressus, sp. nov. Holotype, $\times 0.9$; dorsal view; near Juana Diaz, Porto Rico; Amer. Mus. Nat. Hist. No. 18573.

FIG. 8. Eupatagus elegans, sp. nov. Paratype, $\times 0.9$; ventral view; near Juana Diaz, Porto Rico; Amer. Mus. Nat. Hist. No. 18575.

Plate 17.

FIg. 1. Eupatagus elegans, sp. nov. Holotype, $\times 0.9$; dorsal view; near Juana Diaz, Porto Rico; Amer. Mus. Nat. Hist. No. 18574.

FIG. 2. Eupatagus vaughani, sp. nov. Holotype, $\times 1$; ventral view (for dorsal and side views of same specimen see plate 18); north side of Willoughby Bay, Antigua; U. S. Nat. Mus. No. 328245.

Plate 18.

FIGs. 1, 2. Eupatagus vaughani, sp. nov. Holotype, $\times 1$; (1) dorsal and (2) right side views of same specimen (for ventral view of same, see plate 17); north side of Willoughby Bay, Antigua; U. S. Nat. Mus. No. 328245. 



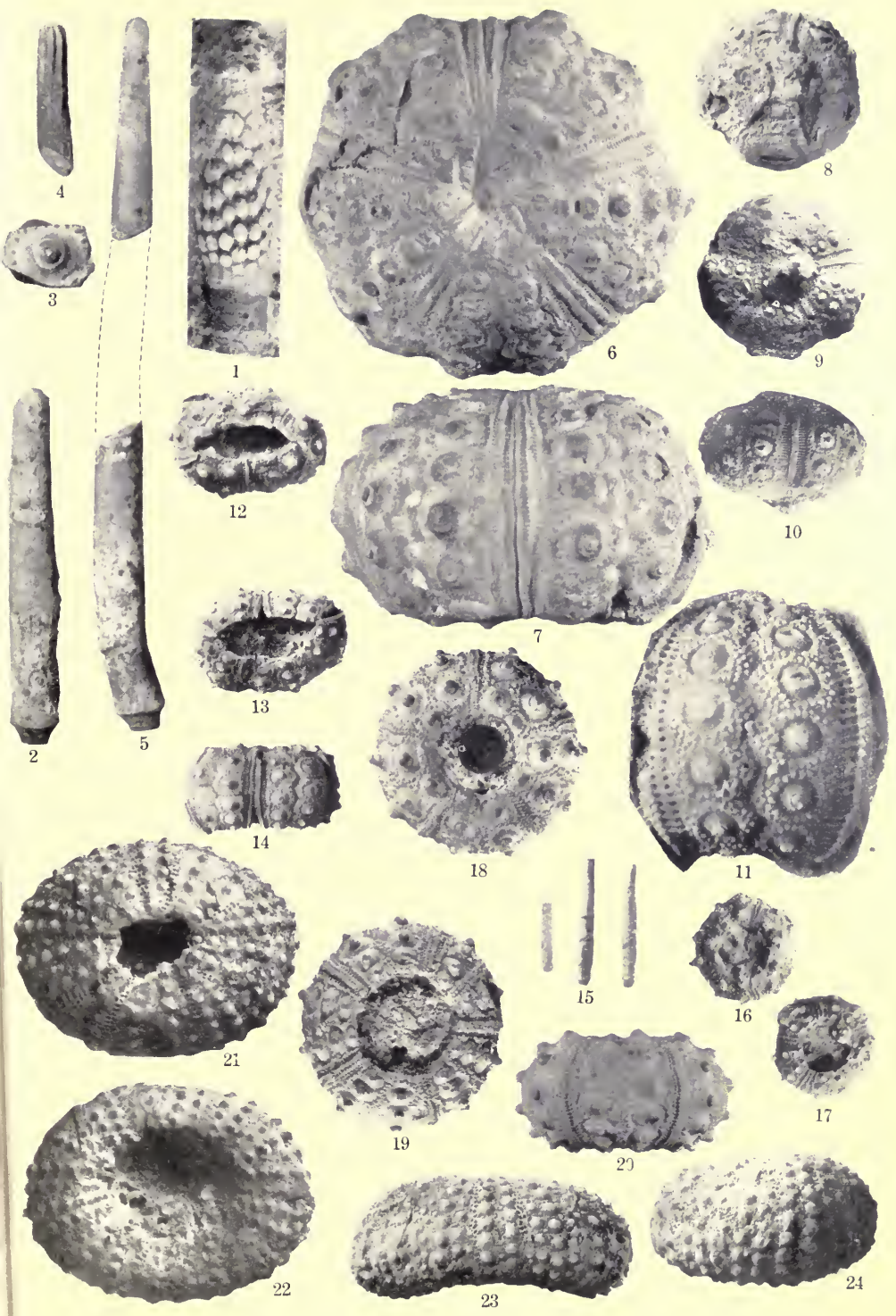

8 to 10. C.loveni.

18 to 20. C. tribuloides.

to 5. ('. peloria.

11. C. clevei.

21 to 24 . Echinometra prisca.

6, 7. C. forcatis.

12 to 17 . C. melitensis. 



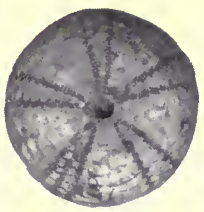

1

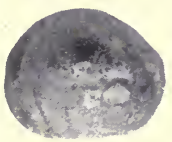

3
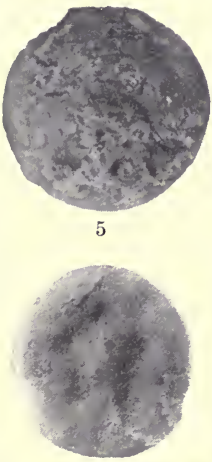

6

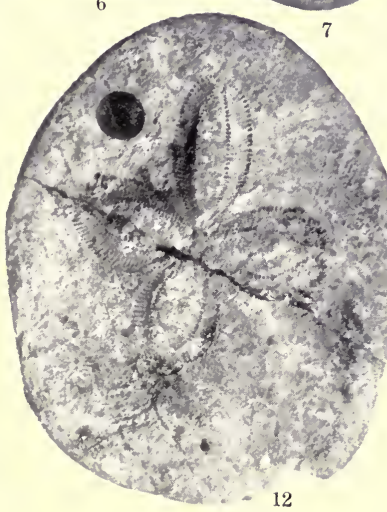

1. Echinopedina cubensis

2 to 5 . Lanicria lanieri.
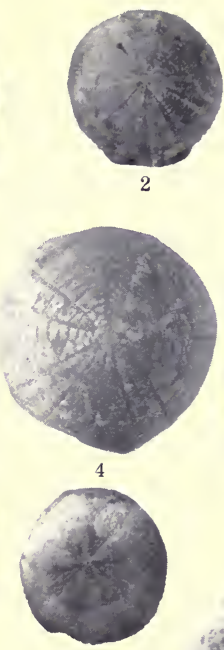

8

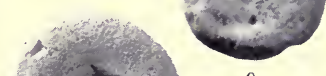

9

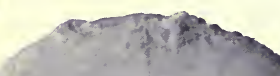

11

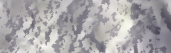

man $\sin 5 x+3$ ing
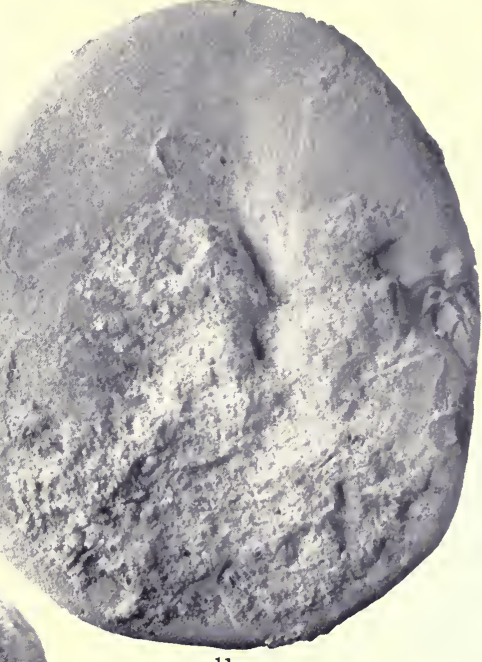

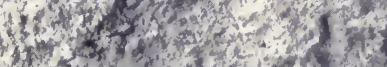

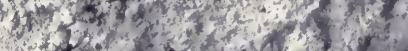

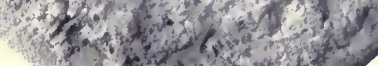
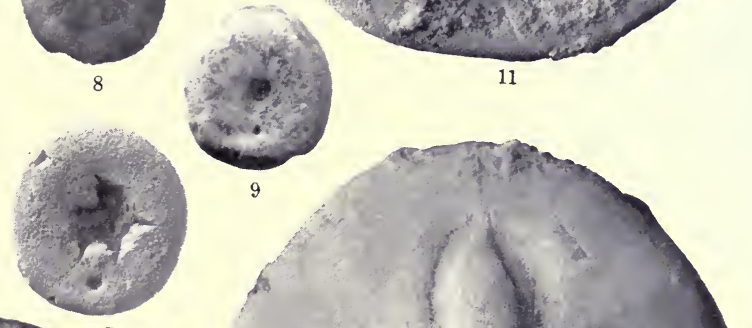



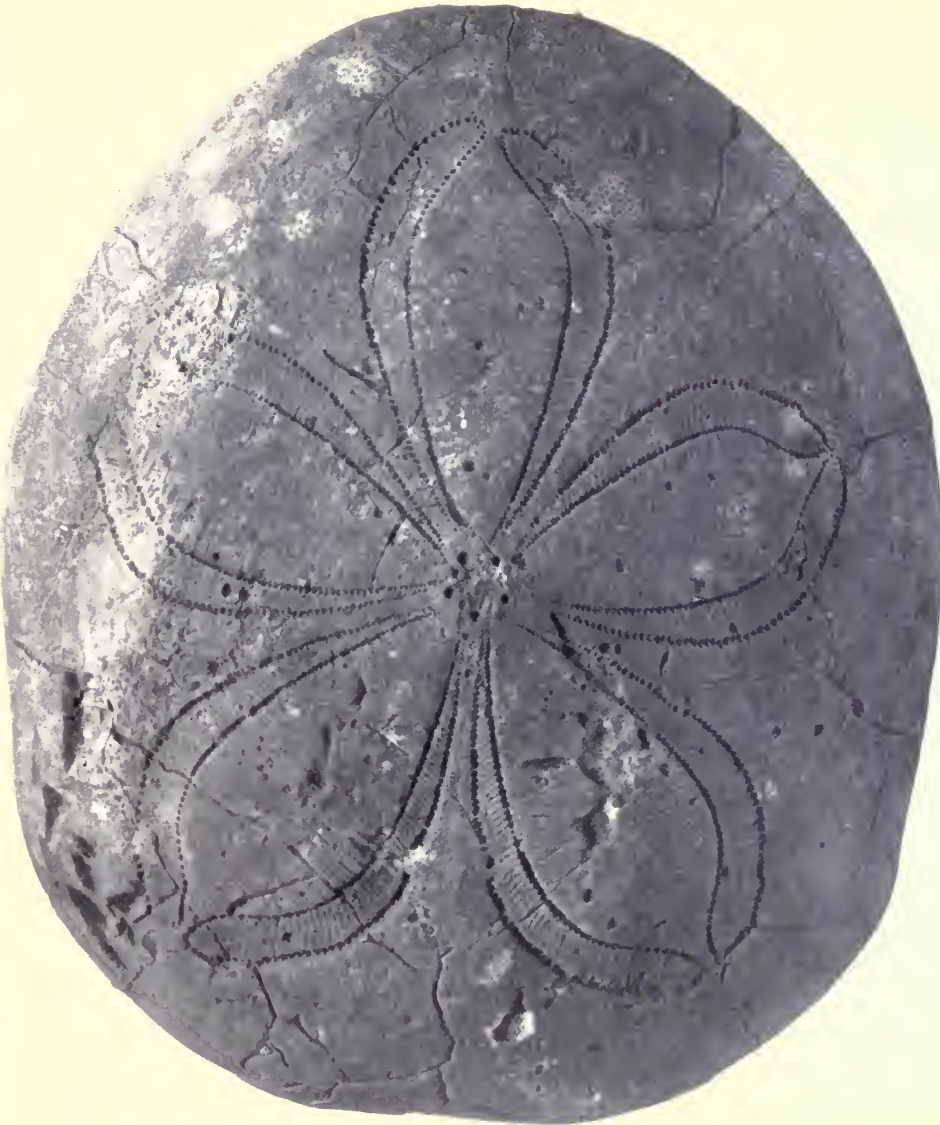

1

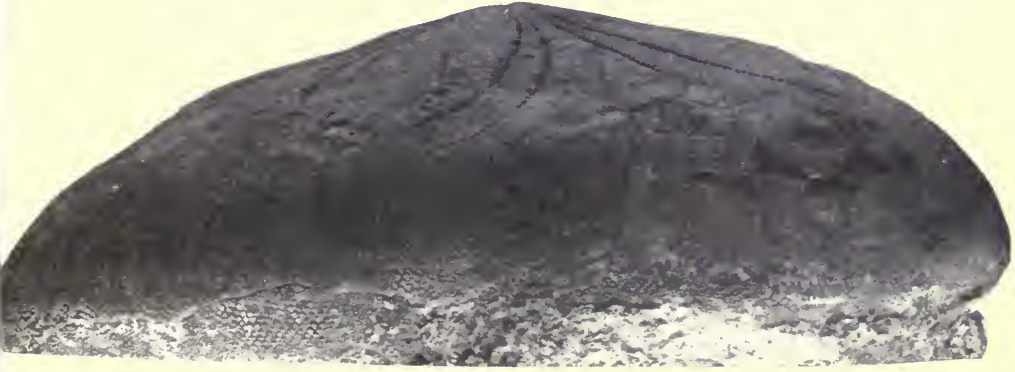





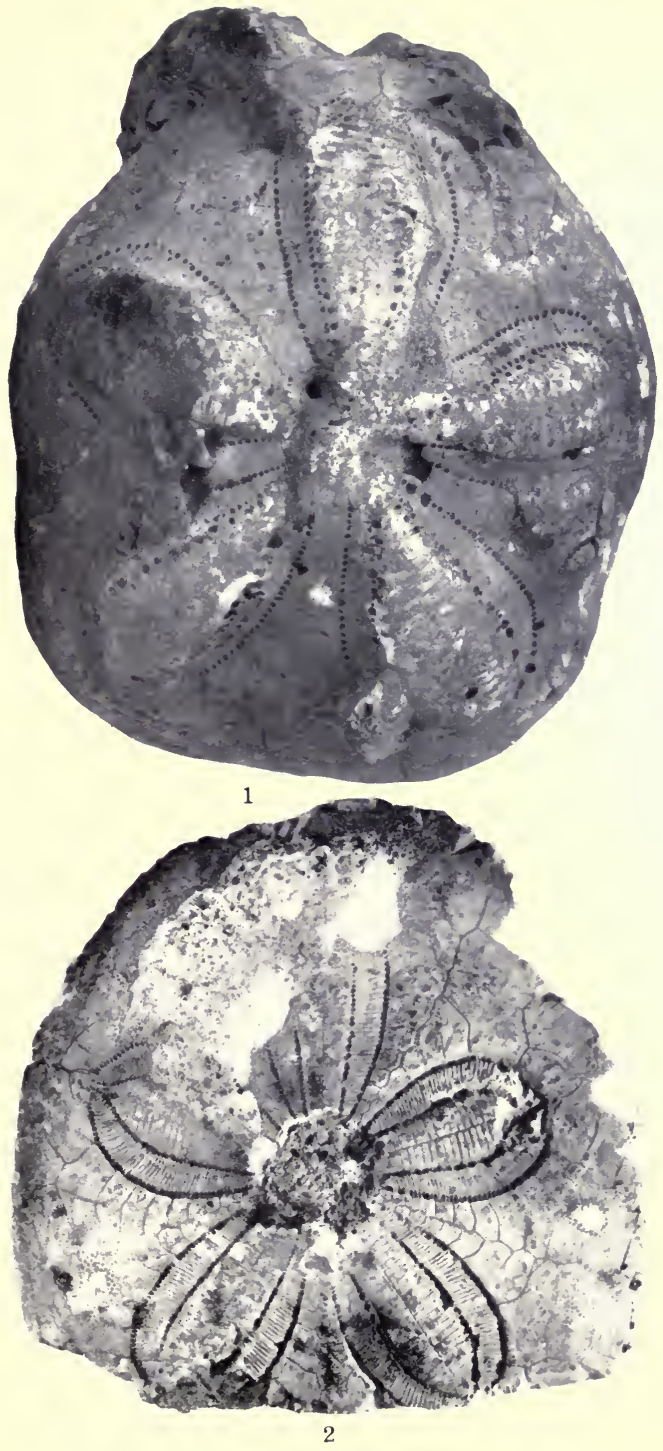
1. Clypeaster dalli.
2. C. lanceolatus. 



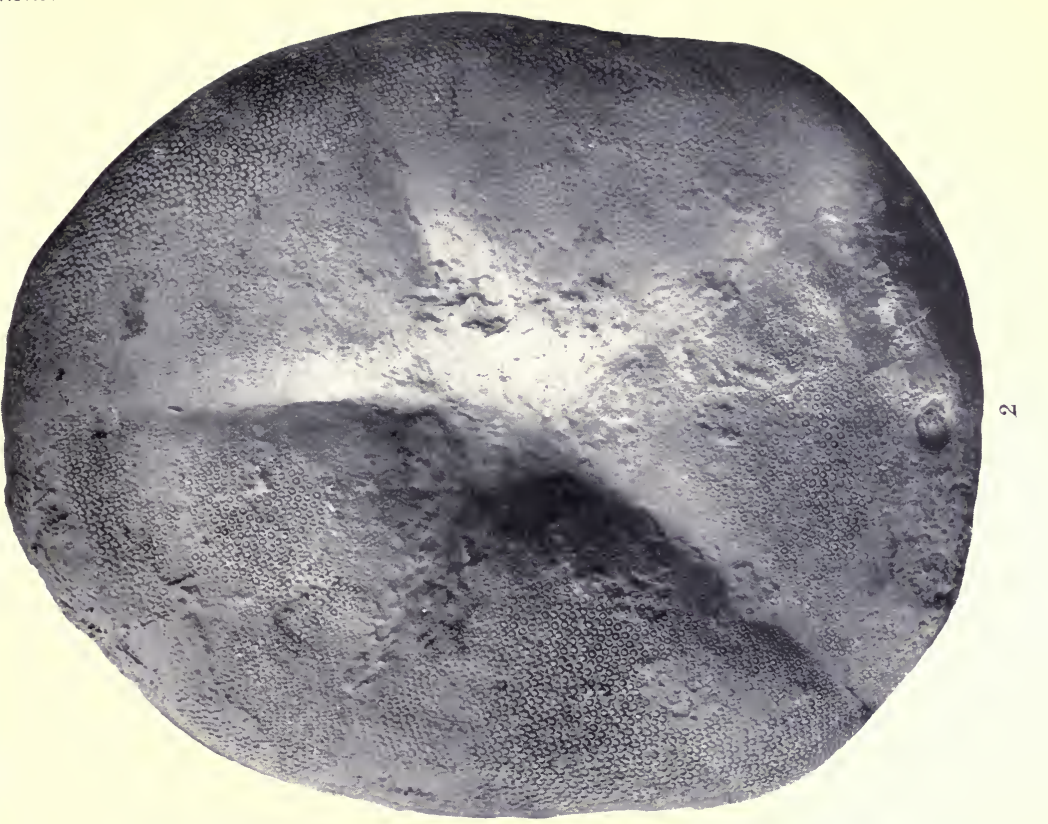

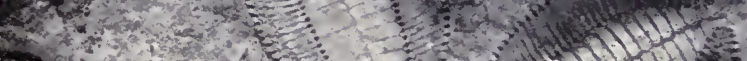

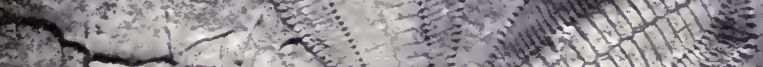

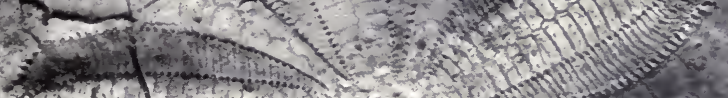

(x, 0,1 .

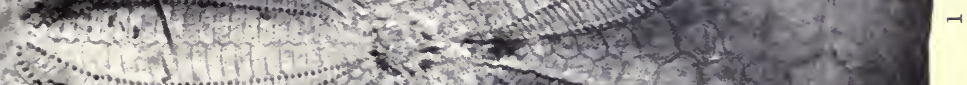

Then

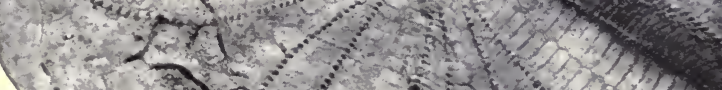

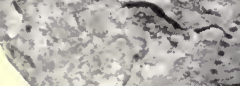

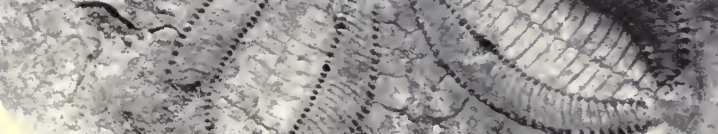

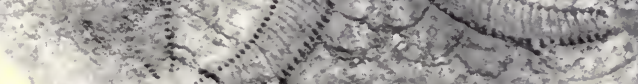

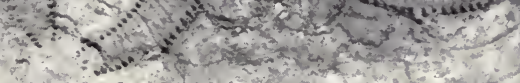




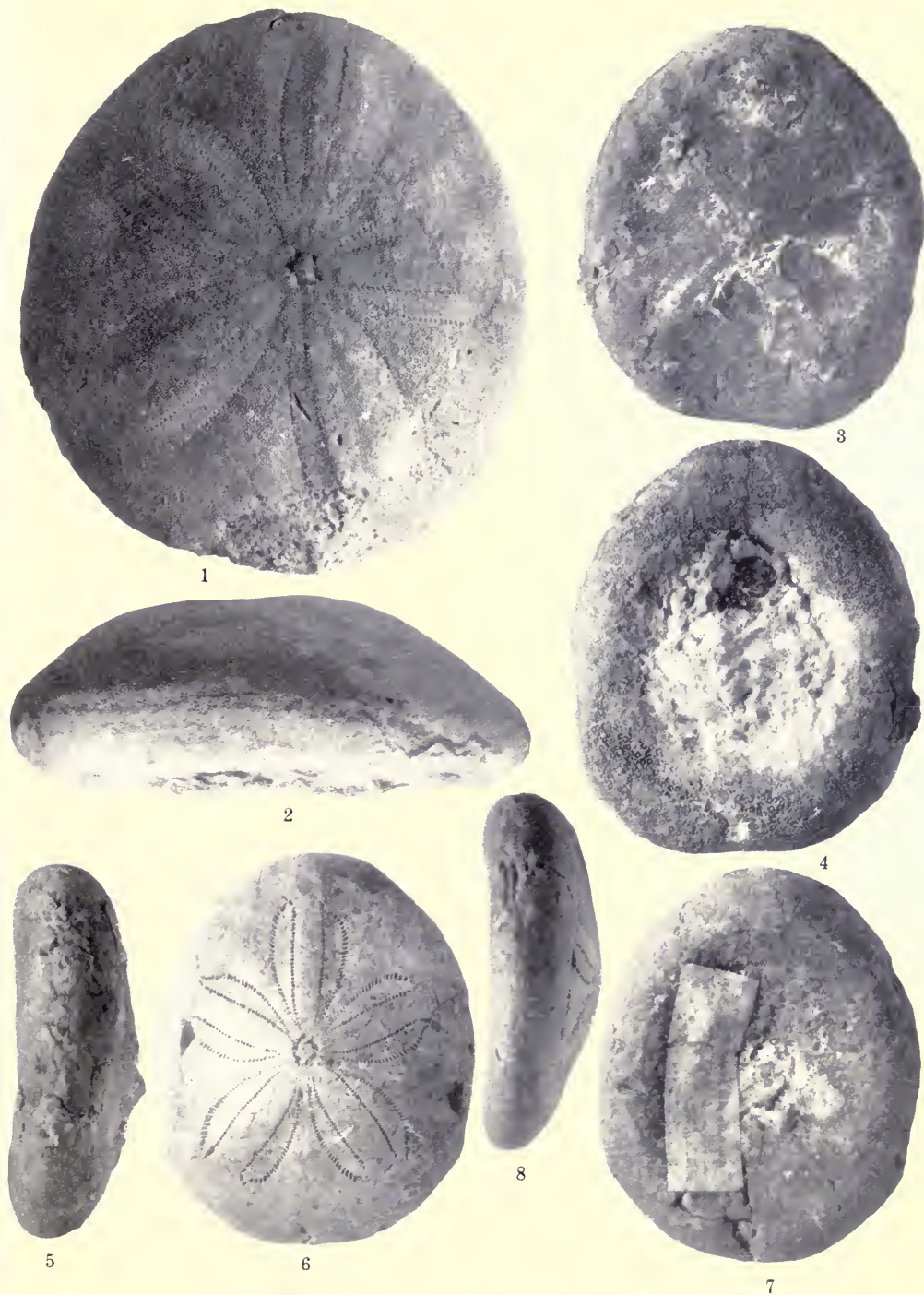

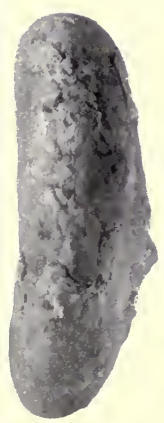

5

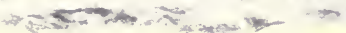

2
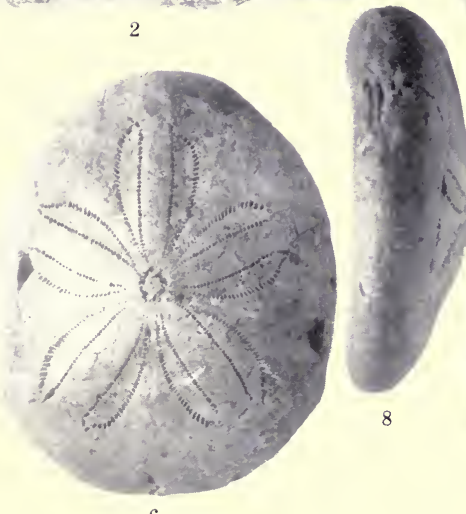

1,2. Clypeaster planipetalus.

3 to 5. C. cryptopetalus.

6 to 8. C. cotteaui. 



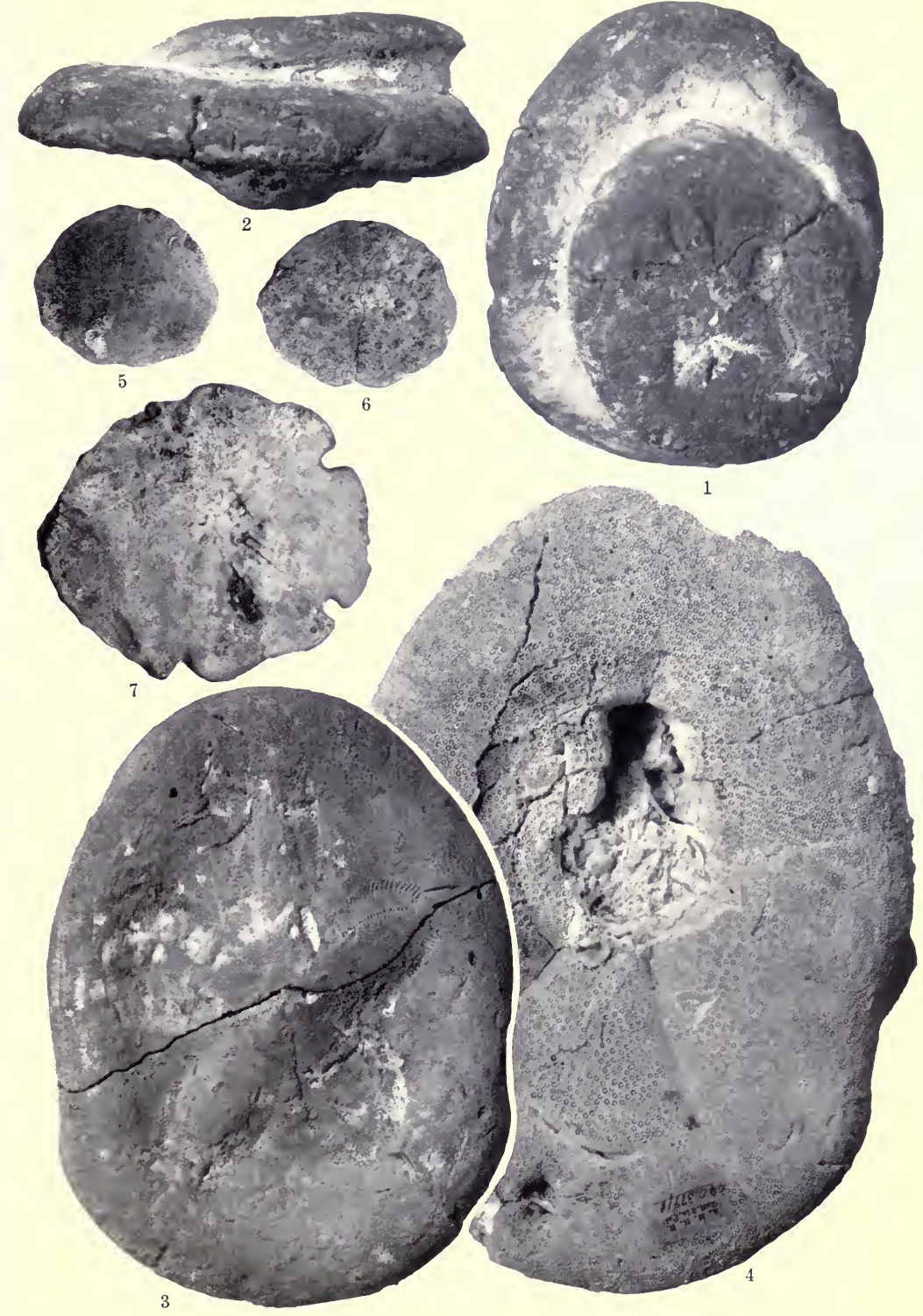

1, 2. Clypeaster placentoides. 3, 4. C. oxybaphon.
5, 6. Echinarachnius sebastiani.

7. Encope latus. 



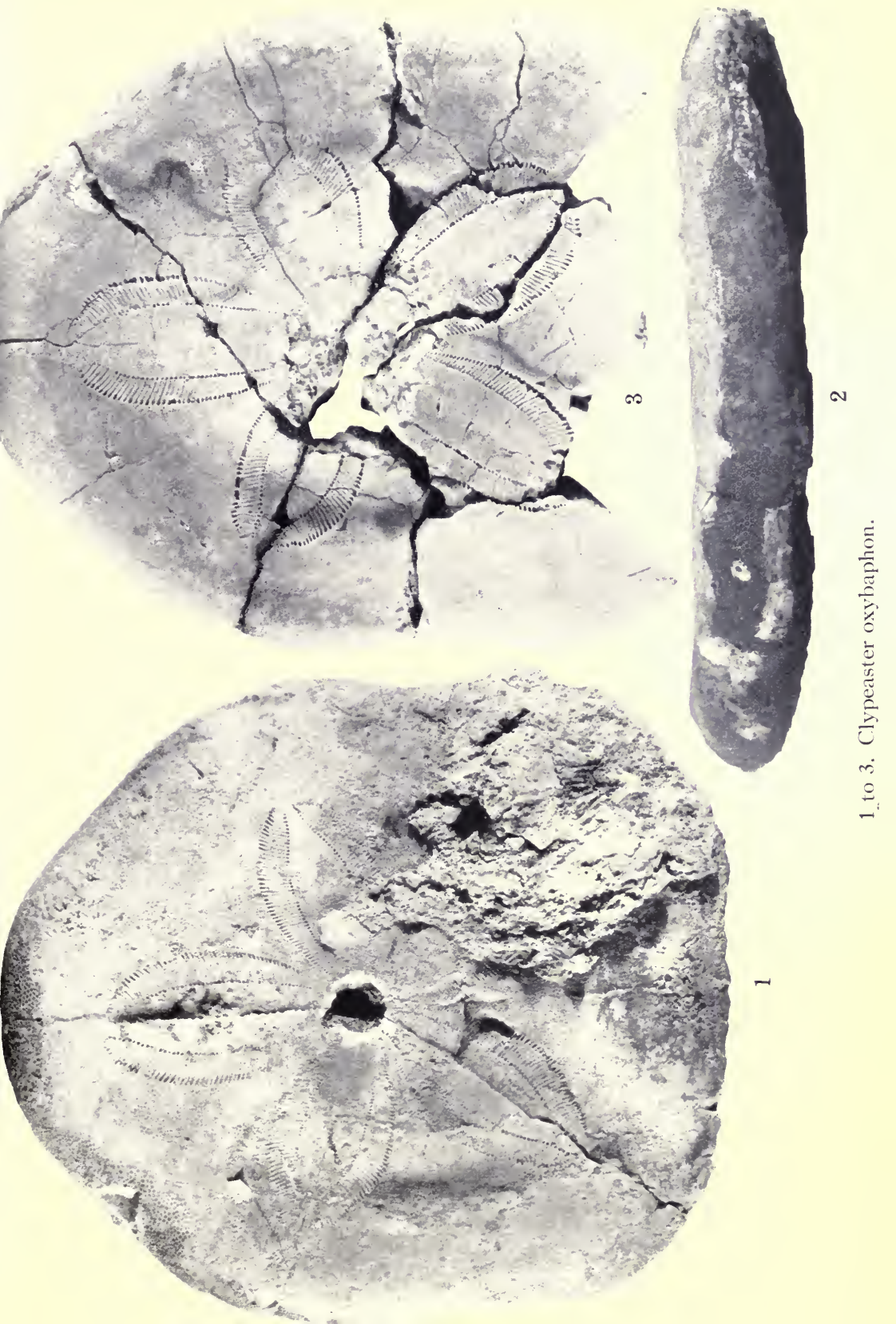




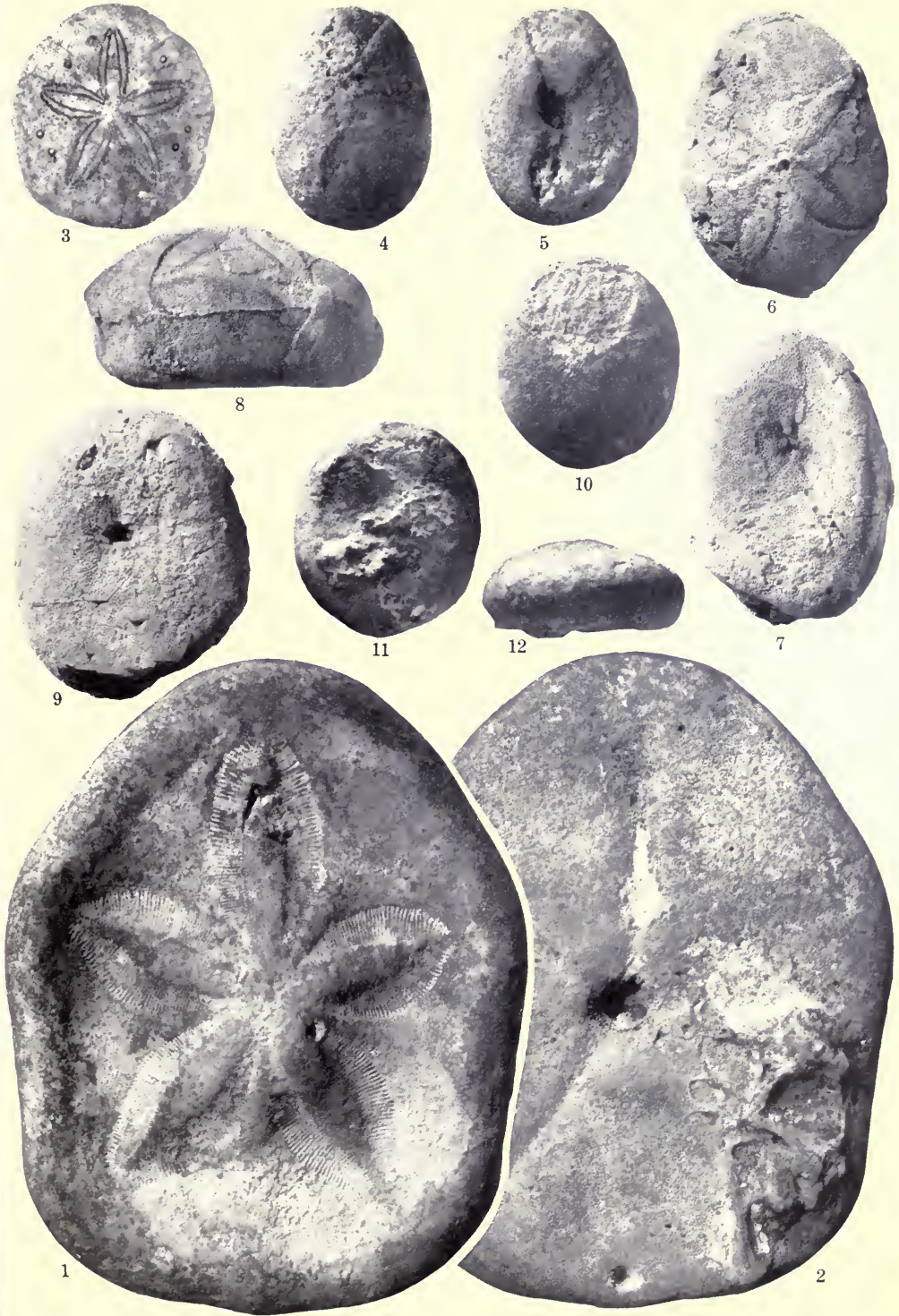

1, 2. Clypeaster platygaster.

3. Peronella mirabilis.

4, 5. Echinoneus cyclostomus 6 to 9. Parapygus antillarum. 10 to 12 . Echinolampas antillarum. 


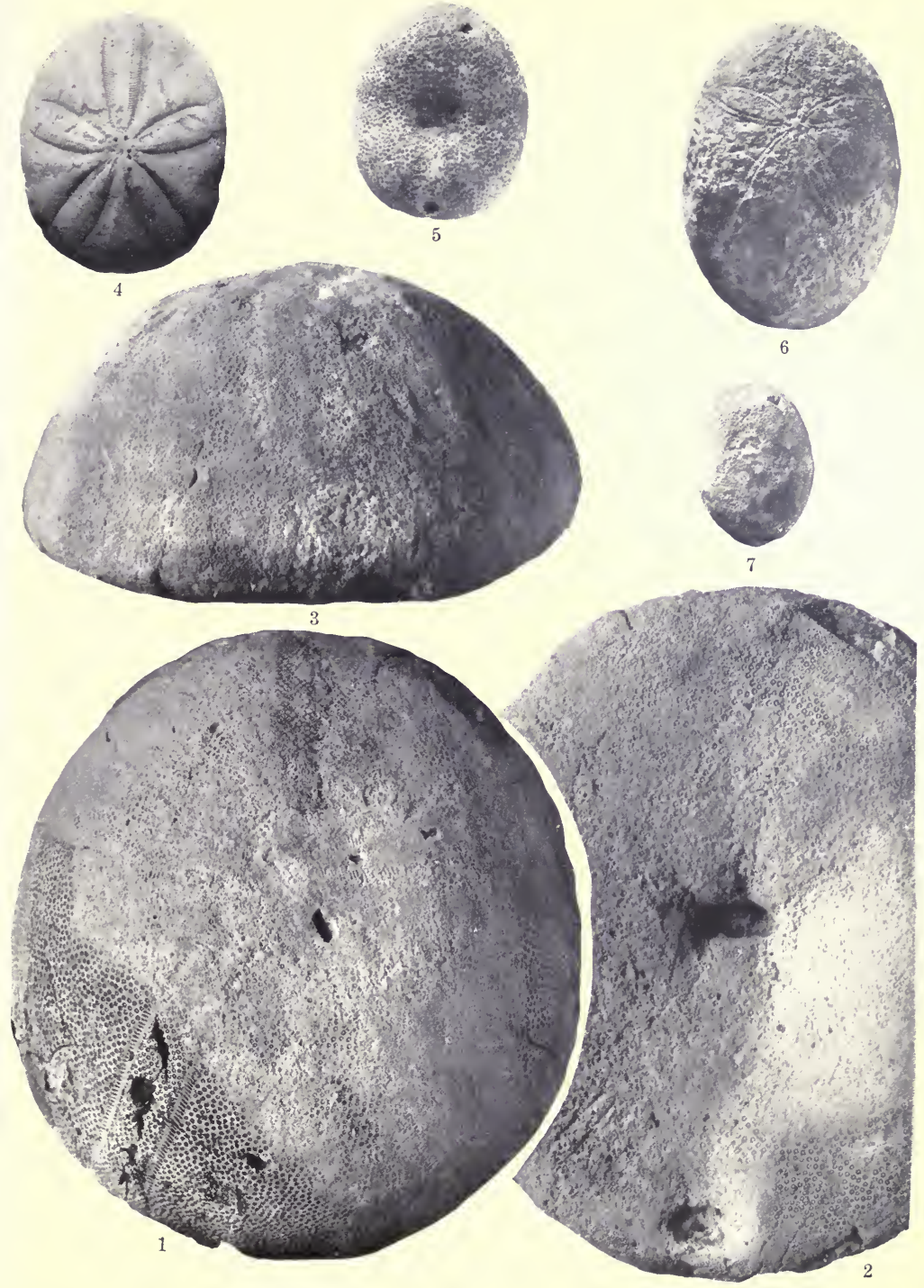

1 to 3. Echinolampas semiorbis.

4, 5. E. ovumserpentis.

6, 7. F. clevei. 



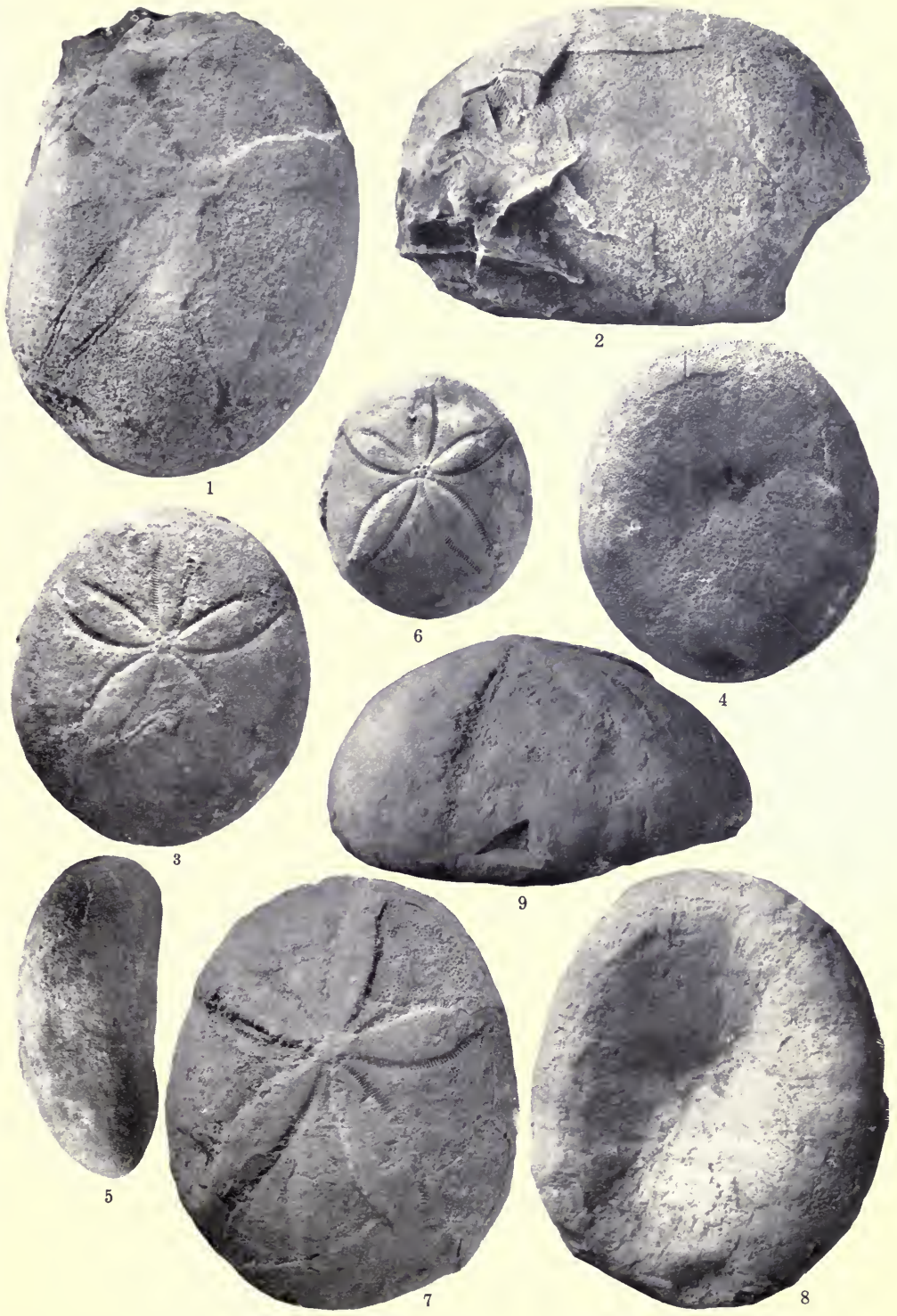

1, 2. Echirolampas clevei.

3 to 6 . E. lycopersicus.

7 to 9 . E. anguilla. 




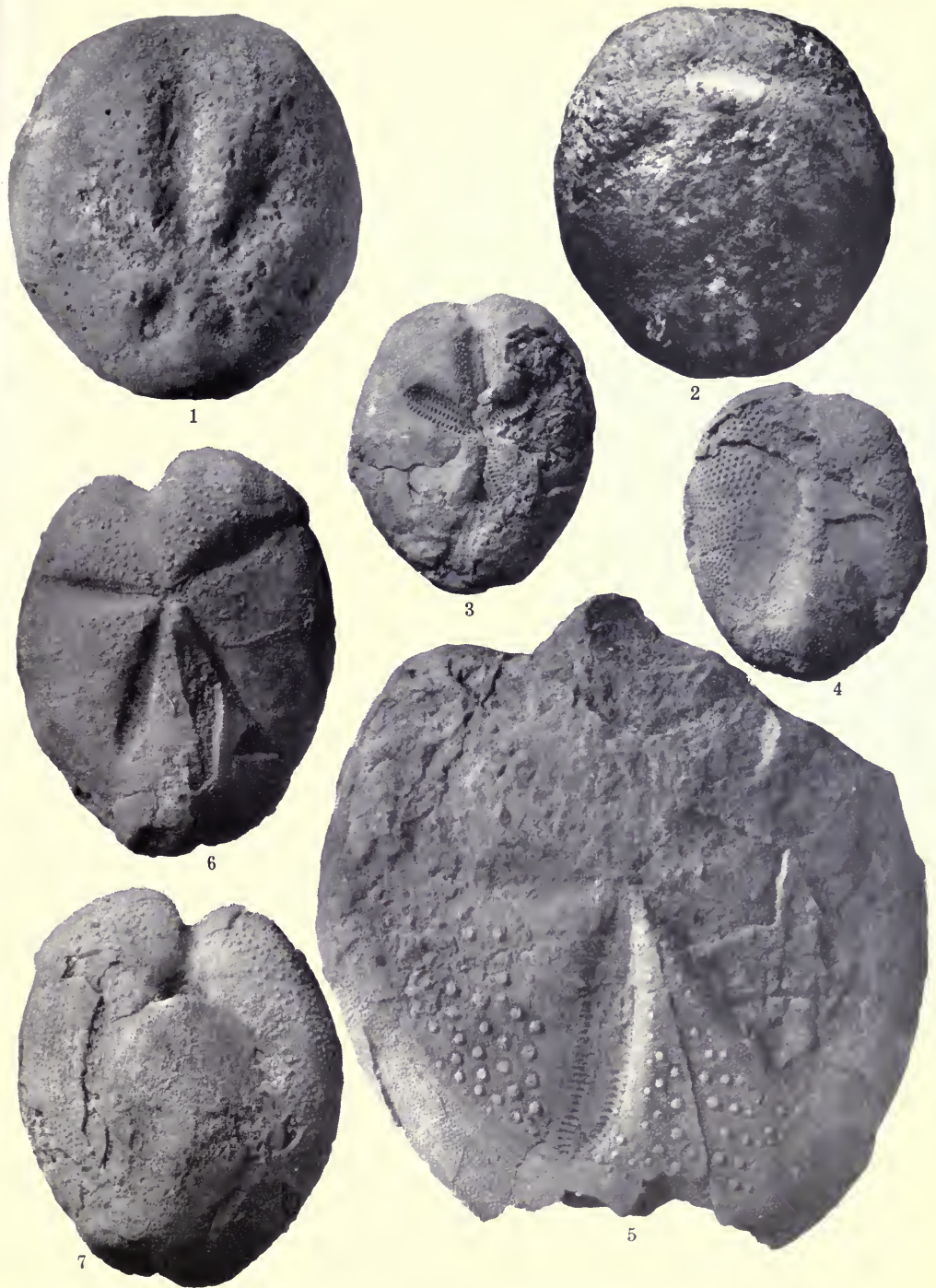

1,2. Paraster subcylindricus.

5. Plagiobrissus loveni.

3,4 . Brissopsis antillarum.

6, 7. Macropneustes clevei. 


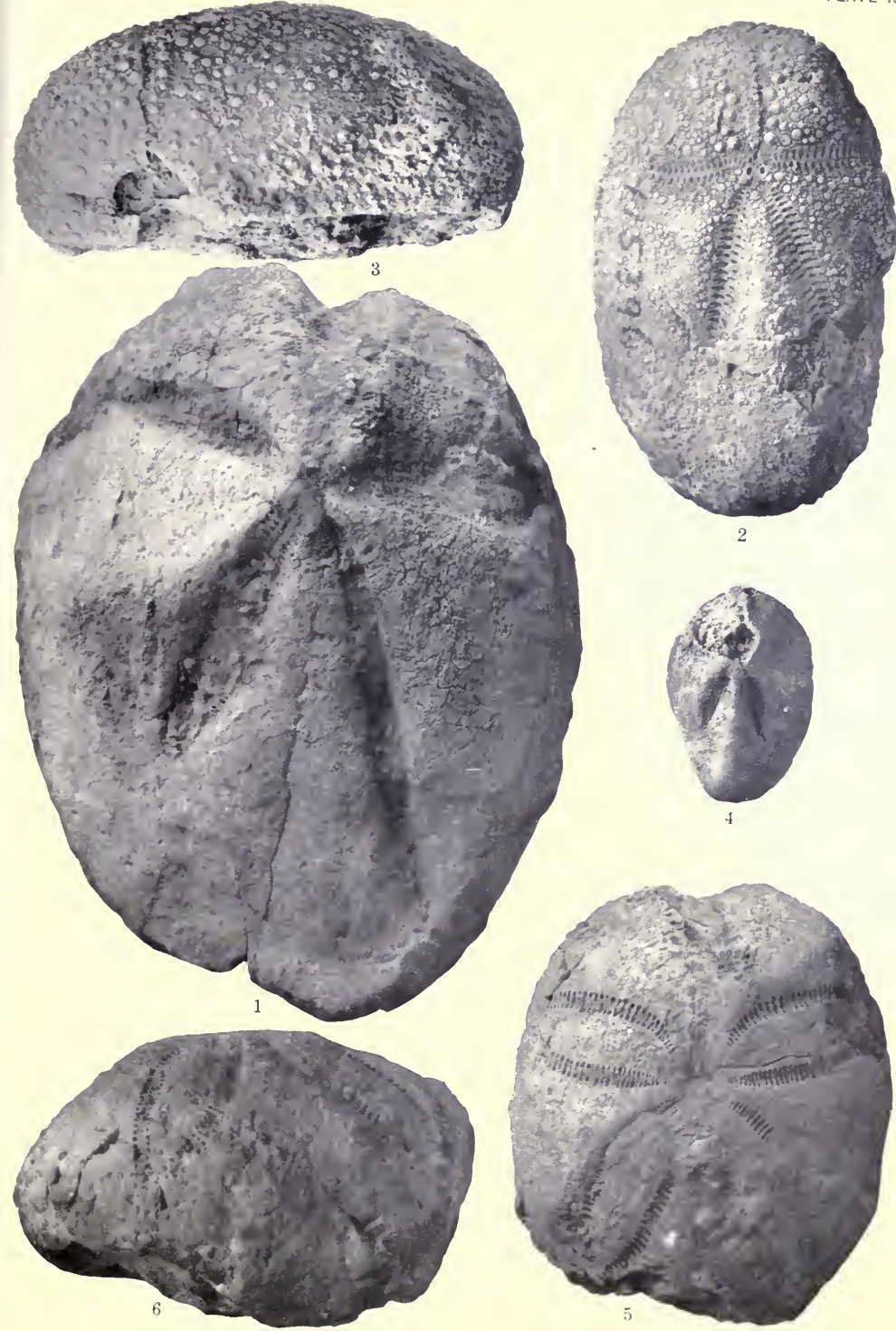

1. Macropneustes antillarum.

5, 6. Eupatagus grandiflorus. 



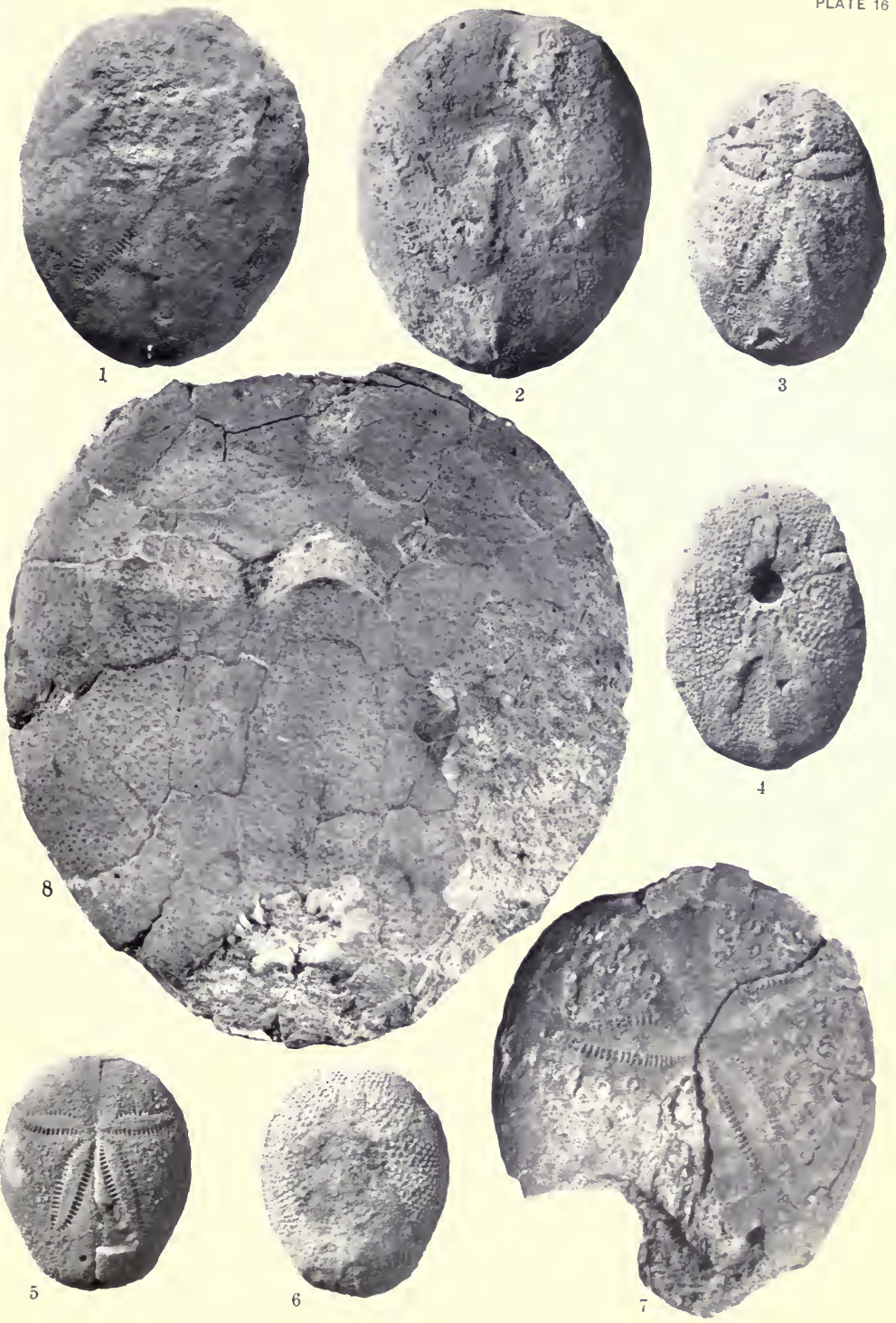

1, 2. Eupatagus clevei. 7. E. depressus.

3 to 6. E. antillarum. S. E. elegans. 



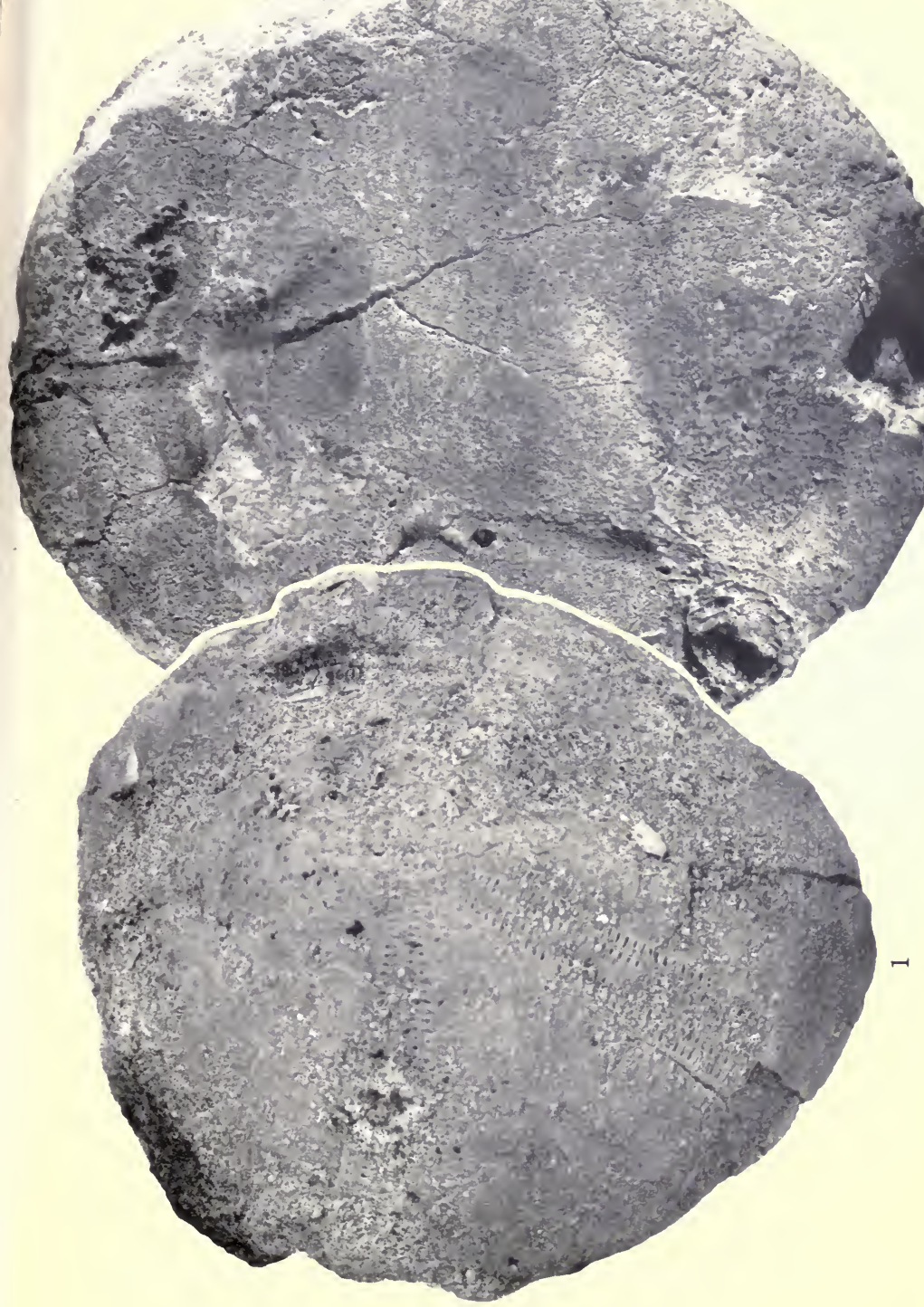






\title{
STRATIGRAPHIC SIGNIFICANCE OF THE SPECIES OF WEST INDIAN FOSSIL ECHINI.
}

\author{
By Thomas Wayland Vaughan, \\ Geologist in charge of Coastal Plain Incestigations \\ and West Indian Geological Surveys, U. S. Geological Survey.
}





\section{STRATIGRAPHIC SIGNIFICANCE OF THE SPECIES OF WEST INDIAN FOSSIL ECHINI.}

\section{INTRODUCTION.}

In order that the geologist who is particularly concerned with problems in stratigraphic geology may easily utilize the results of the detailed study of Doctor Jackson, it seems desirable to have in succinct form what is definitely known of the stratigraphic occurrence of the species of echinoids described in his paper.

The present status of the correlation of the West Indian Tertiary formations is indicated in the accompanying correlation table ${ }^{1}$ (p. 109), taken, with slight modifications, from a report issued in December, 1921. The Dominican Republic exhibits the most comprehensive succession of Tertiary strata at present known in the West Indies, and the section there exposed may appropriately be used as a reference section for that region. It may also be stated that there is no possibility of error in the stratigraphic succession of the Dominican formations as indicated in the accompanying table.

For the benefit of those who may wish to examine the recent literature on the correlation of West Indian and Central American Tertiary formations and who may wish to know what other organisms are associated with the echinoids described by Doctor Jackson, a list of recent publications is here given:

Recent Papers on Geologic Correlation of West Indian Tertiary Deposits.

Cooke, C. Wythe. Stratigraphic significance of Orthaulax (abstract): Geol. Soc. Amer. Bull., vol. 31, p. 206, 1920.

Geologic reconnaissance in Santo Domingo (abstract): Geol. Soc. Amer. Bull., vol. 31, pp. 217-219, 1920. Correlation table on p. 219.

*Orthaulax, a Tertiary guide fossil: U. S. Geol. Survey Prof. Paper 129, pp. 23-37, pls. 2-5, 1921.

Stratigraphic and structural geology and geologic history: Dom. Rep. Geol. Survey, Mem., vol. 1, chap. 4, pp., 50-82, pls. 8-13, 1921.

Hubbard, Bela. The Tertiary formations of Porto Rico: Science, n.s., vol. 51, pp. 395, $396,1920$.

MAURy, CarlotTA J. On the correlation of Porto Rican Tertiary formations with other Antillean and mainland horizons: Amer. Jour. Sci.: ser. 4, vol. 48, pp. 209, 215, 1919.

*Tertiary Mollusca from Porto Rico: New York Acad. Sci.: Scientific Survey of Porto Rico and the Virgin Islands, vol. 3, pt. 1, pp. 1-77, 9 pls., 1920.

VAughan, Thomas Wayland. Correlation of the Tertiary geologic formations of the southeastern United States, Central America, and the West Indies: Wash. Acad. Sci. Jour., vol. 8, pp. 268-276, 1918.

Geologic history of Central America and the West Indies during Cenozoic time. Geol. Soc. Amer. Bull., vol. 29, pp. 615-630, 1919.

${ }^{1}$ T. W. Vaughan, C. Wythe Cooke, D. D. Condit, C. P. Ross, W. P. Woodring, and F. C. Calkins, A geological reconnaissance of the Dominican Republic: Dominican Repub. Geological Survey, Memoirs, vol. 1, 268 pp., 23 pls., 1921.

*The three papers marked with asterisks in this list contain systematic descriptions of fossils, but their titles are not repeated in the next list. 
Vaughan, Thomas Wayland. * Fossil corals from Central America, Cuba, and Porto Rico, with an account of the American Tertiary, Pleistocene, and Recent coral reefs: U. S. Nat. Mus. Bull. 103, pp. 189-524, i-xiv, pls. 68-152, 1919.

The biologic character and geologic correlation of the sedimentary formations of Panama in their relation to the geologic history of Central America and the West Indies: U. S. Nat. Mus. Bull. 103, pp. 547-612, 1919.

Stratigraphy of the ${ }^{-V i r g i n}$ Islands of the United States and of Culebra and Vieques Islands (abstract): Geol. Soc. Amer. Bull., vol. 31, pp. 216-217, 1920.

and WENDELL P. WoODRING. Tertiary and Quaternary stratigraphic paleontology (of the Dorrinican Republic): Dom. Repub. Geol. Sur., Mem., vol. 1, chap. v, pp. 89-168, 1921.

\section{Recent Papers on West Indian Palcontology.}

Berry, E. W. Tertiary fossil plants from the Dominican Republic: Proc. U. S. Nat. Mus., vol. 59, pp. 117-127, pl. 21, 1921.

Canu, F., and R. S. Bassler. Fossil Bryozoa from the West Indies: Carnegie Inst. Wash. Pub. No. 291, pp. 73-102, 7 pls., 1919.

Cooke, C. Wythe. Tertiary Mollusca from the Leeward Islands and Cuba: Carnegie Inst. Wash. Pub. No. 291, pp. 103-156, 16 pls., 1919.

Cushman, Joseph A. Fossil Foraminifera from the West Indies: Carnegie Inst. Wash. Pub. No. 291, pp. 21-71, 15 pls., 1919.

The American species of Orthophragmina and Lepidocyclina: U. S. Geol. Sur. Prof. Paper 125, pp. 39-108, pls. 7-35, 1920.

- American species of Operculina and Heterostigina and their faunal relations: U. S. Geol. Sur. Prof. Paper 128, pp. 125-137, pls. 18-21, 1921.

Howe, Marshall A. Tertiary calcareous algæ from the islands of Saint Bartholomew, Antigua, and Anguilla: Carnegie Inst. Wash. Pub. 291, pp. 9-19, 6 pls., 1919.

Hubbard, Bela. Tertiary Mollusca from the Lares District, Porto Rico: New York Acad. Sci., Scientific Survey of Porto Rico and the Virgin Islands, vol. 3, pt. 2, pp. 79164, pls. 10-25, 1920.

Maury, Carlotta J. Santo Domingo type sections and fossils: Amer. Pal. Bull., vol. 5, pp. $165-459$, pls. 29-67, 1917.

Rathbun, Mary J. West Indian Tertiary Decapod Crustacea: Carnegie Inst. Wash. Pub. No. 291, pp. 157-184, 9 pls., 1919.

- Additions to West Indian Tertiary Decapod Crustaceans: U. S. Nat. Mus. Proc., vol. 58 , pp. $381-384$, pl. $25,1920$.

Before beginning the detailed discussion of the stratigraphy of the West Indian echinoid faunas, it is appropriate to call attention to the fact that this paper by Doctor Jackson, in connection with other papers, makes our knowledge of North American, Central American, and West Indian Mesozoic and Tertiary echinoids as complete as present available collections permit. The other papers are listed below:

BöSE, Emrlı. Sobre algunas faunas Tertiarias de Mexico: Inst. Geol. de Mexico, Bol. No.22, 97 pp., 12 pls., 1906.

Monografía geológica y paleontológica del Cerro Muleros: Inst. Geol. de Mexico, Bol. No. 25, vi +193 pp., 2 maps, 48 pls., 1910.

Clark, W. B., and M. W. Twitchell. The Mesozoic and Cenozoic Echinodermata of the United States: U. S. Geol. Sur. Mon., vol. 54, 341 pp., 108 pls., 1915.

Jackson, R. T. Fossil Echini of the Panama Canal Zone and Costa Rica: U. S. Nat. Mus. Bull. 103, pp. 103-116, I, pls. 46-52, 1918.

KEW, W.S.W. Description of species [of fossil echinoids] in "The fauna of a medial Tertiary formation and the associated horizons of northeastern Mexico," by Roy E. Dickerson and W. S. W. Kew: Calif. Acad. Sci. Proc., ser. 4, vol. 7, pp. 132-156, pls. 17-26, 1917.

- Cretaceous and Cenozoic Echinoidea of the Pacific Coast of North America: Univ. Calif. Pub. in Geol., vol. 12, pp. 23-236, pls. 3-42, 5 text-figs., 1920. 
and lower Oligocene species. At the time the manuscript for their monograph was prepared, the Ocala limestone was supposed to be of Oligocene age. Later C. W. Cooke showed that its horizon is upper Eocene." Doctor Cooke has for several years been studying the stratigraphy and the faunas of the upper Eocene and lower Oligocene formations of the southern and southeastern United States, and intends in a future paper to present a complete account of the stratigraphic distribution of the echinoids found in these deposits. He has already published some information on this subject in the paper cited below. ${ }^{2}$ Notwithstanding Kew's careful descriptions and good figures of the Tertiary echinoids from northeastern Mexico, knowledge of them is deficient, mostly because of the inadequacy of the data on their stratigraphic relations. Recently I have had an opportunity to review in the field the stratigraphy of the Tertiary formations in eastern Mexico and large collections of echinoids have come into my hands. Therefore it is hoped that before a great while an adequate account of the echinoids from this region, accompanied by proper stratigraphic data, may be made available to stratigraphers and palæontologists.

\section{CRETACEOUS SPECIES.}

List of species of West Indian Cretaceous Echinoids.

\begin{tabular}{|c|c|}
\hline Names of species. & Localities. \\
\hline Codiopsis arnaudi Cotteau . . . . . & Santa Lucía, Cuba. \\
\hline Salenia scutigera (Münster) ... . & Do. \\
\hline Phymosoma cubense (Egozcue). & Cienfuegos, Cuba. \\
\hline Conulus antillensis (Cotteau) ... & Do. \\
\hline Lanieria lanieri (Cotteau) . . . . . & Do. \\
\hline Discoidea decorata Desor ....... & Do. \\
\hline Cardiaster cubensis Jackson . . . . & Valley of Rio Yateras, Cuba. \\
\hline Hemiaster berkeyi Jackson ..... & Guanica, Porto Rico. \\
\hline
\end{tabular}

All of the species above listed, except Hemiaster berkeyi, described as new by Doctor Jackson, are known only from Cuba. With reference to the Cuban specimens, it is regrettable that the precise stratigraphic relations under which they occur are not known. Some specimens from Santa Lucía are referred by Cotteau and Egozcue to the Cretaceous and others from the same locality are referred to the Eocene. Specimens from Cienfuegos are referred to the Cretaceous, Eocene, and Miocene. Additional collections made according to the stratigraphic position of the specimens are not available, but it seems probable that the eight species here considered are of Cretaceous age.

\footnotetext{
${ }^{1}$ Cooke, C. W., Age of the Ocala limestone: U. S. Geol. Sur. Prof. Paper 95, pp. 107-117, 1915.

${ }^{2}$ Cooke, C. W., The stratigraphic position and faunal associates of the orbitoid Foraminifera of the genus Orthophragmina from Georgia and Florida: U. S. Geol. Sur. Prof. Paper 108, Dp. $109-113,1917$.
} 


\section{EOCENE SPECIES.}

List of species of West Indian Eocene Echinoids.

\begin{tabular}{|c|c|c|}
\hline Name of species. & Locality and formation. & Notes. \\
\hline 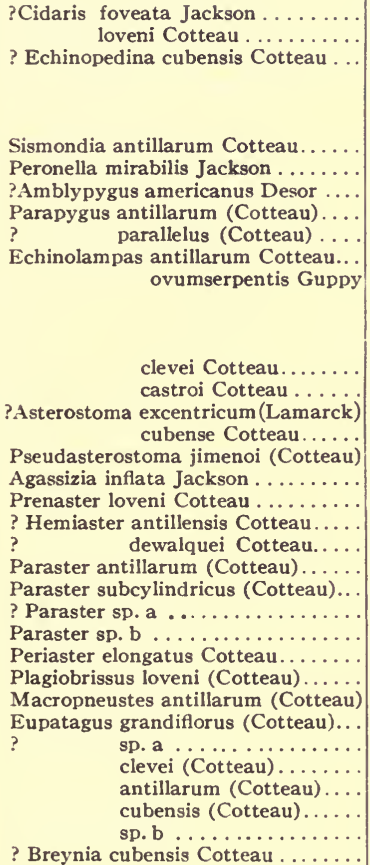 & $\begin{array}{l}\text { St. Bartholomew. } \\
\text { Trinidad, San Fernando formation. } \\
\text { Jamaica. } \\
\text { St. Bartholomew; Santa Lucía, Cuba. } \\
\text { Santa Lucía, Cuba. } \\
\text { St. Bartholomew. } \\
\text { St. Bartholomew; Magazique and } \\
\text { Matanzas, Cuba; Jamaica, } \\
\text { (?) Cambridge formation; Trini- } \\
\text { dad, San Fernando formation. } \\
\text { St. Bartholomew; Matanzas, Cuba. } \\
\text { Matanzas, Cuba (fide Cotteau). } \\
\text { (?) Cuba. } \\
\text { St. Bartholomew; Matanzas, Cuba. } \\
\text { Matanzas, Cuba. } \\
\text { St. Bartholomew. } \\
\text { St. Bartholomew. } \\
\text { Santa Lucía and Concepción, Cuba. } \\
\text { Cienfuegos, Cuba. } \\
\text { St. Bartholomew. } \\
\text { St. Bartholomew. } \\
\text { Jamaica, (?) Cambridge formation. } \\
\text { Trinidad, San Fernando formation. } \\
\text { St. Bartholomew. } \\
\text { St. Bartholomew. } \\
\text { St. Bartholomew, Cuba. } \\
\text { St. Bartholomew. } \\
\text { Jamaica, (?) Cambridge formation. } \\
\text { St. Bartholomew. } \\
\text { St. Bartholomew. } \\
\text { Cuba. } \\
\text { St. Bartholomew. } \\
\text { Matanzas, Cuba. }\end{array}$ & $\begin{array}{l}\text { Miocene, Gurabo } \\
\text { formation, Do- } \\
\text { minican Re- } \\
\text { public. }\end{array}$ \\
\hline
\end{tabular}

In the foregoing list an interrogation mark (?) before the name of a species means that the Eocene age of the species is questionable. Of the 33 species listed, 10 are questioned and 2 of the unquestioned species are not specifically identified, leaving 21. The undoubtedly Eocene species are those from the St. Bartholomew limestone, St. Bartholomew, and the San Fernando formation, Trinidad. At present only species from these two formations may be used with assurance of correctness in the identification of Eocene deposits, by means of echinoids, in the West Indies and Central America. Eocene echinoids have been found in Cuba and Jamaica, but their stratigraphic relations are so imperfectly known that they can not be safely used for correlation purposes. 
It is worthy of note that every undoubtedly Eocene species in the West Indies is confined to the Eocene. These species, therefore, according to present information, are excellent indicators of stratigraphic position.

\section{OLIGOCENE.}

The Oligocene in the West Indies comprises two horizons, which are typified by the Antiguan middle Oligocene and the Anguillan upper Oligocene. ${ }^{1}$ The Anguillan horizon would be referred to the Miocene by many stratigraphers, because it and equivalent horizons are correlated with the European Aquitanian.

MIDDLE OLIGOCENE.

List of species from the West Indian middle (Antiguan) Oligocene.

\begin{tabular}{|c|c|c|}
\hline Names of species. & Localities. & Notes. \\
\hline $\begin{array}{l}\text { batheri Lambert....... } \\
\text { parvus Michelin....... } \\
\text { oxybaphon Jackson.... } \\
\text { Echinarachnius sebastiani Jackson.. } \\
\text { Echinolampas lycopersicus Guppy .. }\end{array}$ & $\begin{array}{l}\text { Antigua; Guanica limestone and } \\
\text { Juana Diaz shales, Porto Rico. } \\
\text { Porto Rico, Collazo, and San Sebas- } \\
\text { tian shales. } \\
\text { Antigua (fide Lambert)............. } \\
\text { Antigua (fide Lambert)............. }\end{array}$ & $\begin{array}{l}\text { Also Anguilla for- } \\
\text { mation. } \\
\text { Also Anguilla for- } \\
\text { mation and its } \\
\text { equivalents. } \\
\text { Emperador lime- } \\
\text { stone, Panama; } \\
\text { ? La Cruz marl, } \\
\text { Cuba. } \\
\text { Anguilla forma- } \\
\text { tion. } \\
\text { Santa Clara Prov- } \\
\text { ince, Cuba. } \\
\text { AlsoGuantánamo } \\
\text { and Matanzas, } \\
\text { Cuba;Jamaica. } \\
\text { Also Guadeloupe } \\
\text { and Havana, } \\
\text { Cuba. }\end{array}$ \\
\hline
\end{tabular}

${ }^{1}$ For discussion, see T. W. Vaughan, U. S. Nat. Mus. Bull. 103, pp. 198-212, 582-586, 1919. 
The names of 19 species, 15 of which are reported from Antigua, occur in the foregoing list. Records of three species are from Lambert. The names of two species are preceded by queries, indicating that their occurrence in the Antigua formation is doubtful. The stratigraphic position of Eupatagus depressus Jackson, one of the questioned species, is not known, but it is probably the Juana Diaz shale; 7 of the 17 unquestioned species range upward to the younger Anguillan horizon or its equivalent, the Emperador limestone of the Panama Canal Zone. It is probable that Clypeaster cotteaui, which is also found at Guantanamo and Matanzas, Cuba, and Jamaica, and Clypeaster parvus, also found at Havana, Cuba, range upward to the Anguillan horizon. If correct, 9 of the Antiguan species are also found at the Anguillan horizon, and only 8 seem to be confined to the Antiguan horizon. The echinoids of the two horizons appear more similar than do the members of other groups of organisms. ${ }^{1}$ It is possible that some of the echinoids reported on by Lambert came from a horizon in Antigua higher than the Antigua formation.

Clypeaster lanceolatus Cotteau, doubtfully present in the Miocene La Cruz marl at Santiago, Cuba, is discussed on page 116.

\section{UPPER OLIGOCENE.}

The names of 21 species occur in the following list, two of which may not occur at this horizon, as is indicated by queries. As the type locality of this division of the Oligocene is the Anguilla formation, island of Anguilla, the species from that formation must be the basis of correlation with other localities. The number of species from the Anguilla formation is 17 , and another species, Clypeaster lanceolatus, occurs in its stratigraphically equivalent formation, the Emperador limestone, in the Panama Canal Zone. Because of identity of other echinoid species found in Havana with Anguillan species, it seems probable that Clypeaster platygaster Jackson also belongs at this horizon, but it will be left out of further consideration. Of the 18 species that may safely be considered as occurring at the horizon of the Anguilla formation, 7 are also reported from the Antigua formation; 1 also occurs and another species may occur in the Miocene of Trinidad, and 2 others may range upward into the Miocene proper. After deducting the species also found in the Antigua formation and those that may also be of Miocene age, there are left only 7 species from the Anguillan horizon, and it is mostly on these that correlation by means of echinoids with that horizon must be based. 
List of species from the West Indian upper (Anguillan) Oligocene.

\begin{tabular}{|c|c|c|}
\hline Names of species. & Localities. & Notes. \\
\hline Cidaris anguillæ Cotteau $\ldots \ldots \ldots \ldots$ & Anguilla. & \\
\hline $\begin{array}{l}\text { clevei Cotteau } \ldots \ldots \ldots \ldots \\
\text { melitensisWright. } \ldots \ldots \ldots \ldots\end{array}$ & $\begin{array}{l}\text { Anguilla. } \\
\text { Anguilla....... }\end{array}$ & $\begin{array}{l}\text { Also Miocene, } \\
\text { Trinidad; Gu- } \\
\text { rabo formation, } \\
\text { Dominican Re- } \\
\text { public. }\end{array}$ \\
\hline Echinometra prisca Cotteau. . & Anguilla............... & $\begin{array}{l}\text { Also Santiago, } \\
\text { Cuba; Guani- } \\
\text { ca Harbor, Por- } \\
\text { to Rico. }\end{array}$ \\
\hline Sismondia anguillæ Cotteau......... & Anguilla.... & $\begin{array}{l}\text { Also Antigua for- } \\
\text { mation. }\end{array}$ \\
\hline Clypeaster concavus Cotteau.... & $\begin{array}{l}\text { Anguilla; Cevicos limestone, Do- } \\
\text { minican Republic. }\end{array}$ & $\begin{array}{l}\text { Also Antigua for- } \\
\text { mation; "Areci- } \\
\text { bo" formation, } \\
\text { Porto Rico; Cu- } \\
\text { ba.1 } \\
\text { Cuba.1 }\end{array}$ \\
\hline $\begin{array}{l}\text { cubensis Cotteau.... } \\
\text { lanceolatus Cotteau }\end{array}$ & Emperador limestone, Panama.... & $\begin{array}{l}\text { Also Antigua for- } \\
\text { mation; Cuba. }{ }^{1}\end{array}$ \\
\hline antillarum Cotteau ..... & Anguilla..... & $\begin{array}{l}\text { Also Antigua for- } \\
\text { mation; Cuba. }\end{array}$ \\
\hline $\begin{array}{r}\text { platygaster Jackson..... } \\
\text { Echinoneus cyclostomus Leske ..... }\end{array}$ & 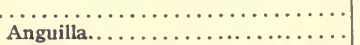 & $\begin{array}{l}\text { Also Cuba. }{ }^{1} \\
\text { Also Cuba. }{ }^{1}\end{array}$ \\
\hline Echinolampas semiorbis Guppy..... & $\begin{array}{l}\text { Anguilla; Emperador limestone, } \\
\text { Panama. }\end{array}$ & Also Cuba. ${ }^{1}$ \\
\hline lycopersicus Guppy.. & Anguilla..................... & $\begin{array}{l}\text { Also Antigua for- } \\
\text { mation ( fide } \\
\text { Lambert); Co- } \\
\text { llazo shale, Por- } \\
\text { to Rico; Cuba. }\end{array}$ \\
\hline anguillæ Cotteau .... & Anguilla....................... & $\begin{array}{l}\text { Also Antigua (fide } \\
\text { Lambert); } \mathrm{Cu}- \\
\text { ba; }{ }^{1} \text { Bissex Hill } \\
\text { formation, Bar- } \\
\text { bados. }\end{array}$ \\
\hline Agassizia clevei Cotteau . . . . . . . & Anguilla. & \\
\hline $\begin{array}{r}\text { ?Paraster parkinsoni (Defrance) } \ldots . . \\
\text { clevei }(\text { Cotteau }) . \ldots \ldots \ldots\end{array}$ & $\begin{array}{l}\text { Anguilla............... } \\
\text { Anguilla.......... }\end{array}$ & $\begin{array}{l}\text { Also Cuba. }{ }^{1} \\
\text { Also Antigua for- } \\
\text { mation. }\end{array}$ \\
\hline loveni (Cotteau) ... & Anguilla... & Also Porto Rico. \\
\hline Macropneustes clevei (Cotteau).... & Anguilla. & \\
\hline Brissopsis antillarum Cotteau ...... & $\begin{array}{l}\text { Anguilla; Cevicos limestone, Do- } \\
\text { minican Republic. }\end{array}$ & \\
\hline Brissus exiguus Cotteau .... & Anguilla......................... & $\begin{array}{l}\text { Also ? Miocene, } \\
\text { Trinidad. }\end{array}$ \\
\hline
\end{tabular}

${ }^{1}$ For special discussion of Cuban post-Eocene Tertiary echinoids, see following pages.

\section{POST-EOCENE TERTIARY ECHINOIDS OF CUBA.}

The probable geologic age of the post-Eocene echinoid-bearing beds of Cuba, Porto Rico, and Barbados needs more detailed discussion.

The following is a table of the post-Eocene Tertiary echinoids of Cuba, with the localities from which they are reported: 
Table of post-Eocene Tertiary Echinoids from Cuba.

\begin{tabular}{|c|c|c|c|c|c|c|c|c|c|c|c|c|c|c|c|c|c|c|}
\hline \multirow[b]{2}{*}{ Names of species. } & \multicolumn{3}{|c|}{$\begin{array}{l}\text { Province } \\
\text { of Pinar } \\
\text { del Río. }\end{array}$} & \multicolumn{2}{|c|}{$\mid \begin{array}{c}\text { Prov- } \\
\text { ince of } \\
\text { Ha- } \\
\text { vana. }\end{array}$} & \multicolumn{3}{|c|}{$\begin{array}{c}\text { Province } \\
\text { of } \\
\text { Matanzas. }\end{array}$} & \multicolumn{4}{|c|}{$\begin{array}{l}\text { Province of } \\
\text { Santa Clara. }\end{array}$} & \multicolumn{3}{|c|}{$\begin{array}{c}\text { Province } \\
\text { of } \\
\text { Oriente. }\end{array}$} & \multicolumn{3}{|c|}{$\begin{array}{l}\text { Occurring } \\
\text { elsewhere. }\end{array}$} \\
\hline & 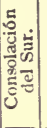 & 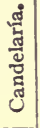 & 窇 & 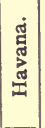 & 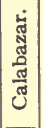 & 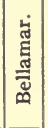 & 离 & 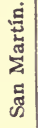 & 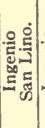 & 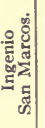 & 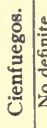 & : & 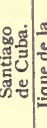 & 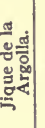 & 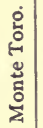 & 䄊 & 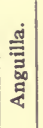 & 造 \\
\hline Cidaris tribuloides (Lamarck) & & & & & & & & & & & & & $x$ & & & & & \\
\hline Echinopedina cubensis Cotteau & & & & & & & & & & & $x$ & & $x$ & & & & & \\
\hline Echinometra prisca Cotteau. & & & & & & & & & & & & & $x$ & & & & $\times$ & \\
\hline Clypeaster rosaceus (Linné).. & & & & & & $x$ & & & & & & & $\hat{\imath}$ & & & & $\hat{\ldots}$ & \\
\hline $\begin{array}{l}\text { concavus Cotteau. } \\
\text { cubensis Cotteau. }\end{array}$ & & & & $x$ & . & & $x$ & $\ldots$ & $x$ & $\times$ & $\times$ & $x$ & & $\times$ & & $x$ & $\ddot{x}$ & \\
\hline parræ Cotteau......... & & & & & & & $x$ & & & & $\cdots$ & & & $\cdots$ & & $\begin{array}{l}\cdots \\
\cdots\end{array}$ & $\cdots$ & \\
\hline lanceolatus Cotteau... & & & & $\times$ & & & $\times$ & & & & & & & & & $\ddot{x} \mid$ & & \\
\hline antillarum Cotteau, $\ldots$ & $x$ & & $\times$ & 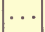 & & & $\cdots$ & $x$ & & & & & & & .. & $x$ & $\times$ & \\
\hline $\begin{array}{l}\text { planipetalus Cotteau .. } \\
\text { cotteaui Egozcue }\end{array}$ & & & & & & & y. & $\cdots$ & $x$ & & & & & ... & $\ldots$ & $x$ & $\cdots$ & \\
\hline parvus Michelin & & & $\cdots$ & $\ddot{x}$ & & & $x$ & $\cdots$ & & & & & & $\cdots$ & $\begin{array}{c}x \\
\ldots\end{array}$ & $\begin{array}{l}x \\
x\end{array}$ & $\cdots$ & $\cdots$ \\
\hline place & & & & & & & & & & & & & & $\ddot{x}$ & & & & $\begin{array}{l}\cdots \\
\ldots\end{array}$ \\
\hline platyg & & & .. & $x$ & & & & & & & & & & & & & & \\
\hline Laganum elongatum Egozcue . & & & $\ldots$ & $\ldots$ & $\ldots$ & & $\times$ & . & & & $\cdots$ & & & $\ldots$ & & & $\cdots$ & $\ldots$ \\
\hline Encope ciæ de Cortázar....... & & & & & $x$ & & & & & & & & & & & & & \\
\hline Echinoneus cyclostomus Leske. & & & & $\cdots$ & $\cdots$ & & & & & & & & $\times$ & & & ... & $\times$ & ... \\
\hline Echinolampas semiorbis Gupp & & & & & & & & $x$ & & & & & & & & & $x$ & \\
\hline lycopersicus Gu ppy & & $x$ & $\cdot$ & & & & & $x$ & & & & & $x$ & & ... & $\times$ & $x$ & . \\
\hline & & & & & & & & & & & & & & $\times$ & & $\times$ & $\times$ & \\
\hline Hemiaster cubensis (d'Orbigny) .... & & & & & & & & & & & & & & & & & & \\
\hline Paraster parkinsoni (Defrance) & & & & & & & $\times$ & & & & & & & & & $\cdots$ & $x$ & \\
\hline Schizaster scillæ Agassiz ... & & & & & & & & & & & $\times$ & & & & & & & \\
\hline Brissopsis jimenoi Cotteau ...... & & & & & . . & & & $\times$ & & & $\times$ & & & & & $\cdots$ & $\times$ & \\
\hline Macropneustes clevei (Cotteau).. & & & & & & & & & & & & & & & & & & \\
\hline Brissus brissus (Leske),$\ldots \ldots \ldots$ & & & & & & & & & & & & & & & & & & \\
\hline
\end{tabular}

The probable age of each of the echinoid-bearing localities in Cuba will now be briefly reviewed.

Consolación del Sur: The one species of echinoid, Clypeaster antillarum, found at this locality occurs both in Antigua and Anguilla, but the mollusks are more similar to those of Anguilla than to those of Antigua. ${ }^{1}$ This locality, therefore, is probably of Anguillan age.

Candelaria: Echinolampas lycopersicus is common in Anguilla but very rare in Antigua, and it is not certain that the specimen from Antigua came from the Antigua formation. The probability is that this locality is also at the Anguillan horizon.

Guajay: Although Clypeaster antillarum found at this locality occurs both at the Antiguan and Anguillan horizons, the presence there of Ostrea haitiensis ${ }^{1}$ indicates a horizon higher than the Antiguan.

Havana: In and around Havana are geological formations of several different ages; there are certainly deposits of Pleistocene, Miocene, and Oligocene age, and perhaps deposits of older age. It is, therefore, highly important to know the stratigraphic relations of beds 
from which collections of fossils were made, but stratigraphic data are lacking in most instances. Two species, Clypeaster lanceolatus and $C$. platygaster, were collected by Dr. Barnum Brown "not far from the University buildings"; $C$. concavus is also found in Havana. The beds from which these specimens come are at either the Antiguan or Anguillan horizon, with the probability rather in favor of the latter. Clypeaster parvus, reported from Havana by Cotteau, is recorded by Lambert from Antigua, where he says it is mixed with Clypeaster lanceolatus and Echinolampas lycopersicus.

Calabazar: Encope cia from this locality is said by de Cortázar to come from upper Miocene deposits. The species probably belongs stratigraphically above the Anguillan horizon.

Bellamar: This locality is probably Pleistocene, but it might be Pliocene.

Matanzas: In the vicinity of Matanzas are deposits of Pleistocene, Miocene, Oligocene, and Eocene age. Clypeaster lanceolatus, C. cotteaui, and Paraster parkinsoni indicate an Oligocene horizon, either Antiguan or Anguillan, or both. Clypeaster cubensis and Laganum elongatum may be Miocene, but new collections with reference to the stratigraphic relations are needed to determine this.

San Martin: This locality seems to be definitely Anguillan Oligocene.

Ingenios San Lino and San Marcos: These two localities are Oligocene, but what horizon they represent is not determinable from the two species of echinoids, Clypeaster concavus and C. planipetalus, found at them.

Cienfuegos: Near this place are strata ranging in age from Cretaceous to Miocene. Without data on stratigraphic relations precise correlation is not possible, but the occurrence near Cienfuegos of Clypeaster concavus and Brissopsis jimenoi show that Oligocene strata, probably the Anguillan horizon, are present there. Echinopedina cubensis, doubtfully referred by Cotteau to the Eocene at Cienfuegos, may be a Miocene species, as Doctor Jackson has identified it in collections from the Gurabo formation, Dominican Republic.

Santa Clara Province, no definite locality: Clypeaster concavus is known from both the Antiguan and the Anguillan Oligocene.

Santiago de Cuba: Specimens of three species collected by Lieut. Fred P. Black, U. S. N., are not accompanied by stratigraphic data. Of these species, Cidaris tribuloides (Lamarck), Echinometra prisca, and Echinoneus cyclostomus Leske occur at the Anguillan horizon. Cidaris tribuloides and Echinoneus cyclostomus are still living in the West Indies. Although these species may come from the Miocene La Cruz marl, their stratigraphic relations are doubtful, because more ancient deposits are present in the vicinity of Santiago. Echinolampas lycopersicus was obtained by de la Torre near Santiago in beds of Oligocene age. 
Jique de la Argolla: Three species of echinoids collected at this locality indicate a deposit of Oligocene age, but the evidence is insufficient to decide what horizon is represented.

Monte Toro: The single species, Clypeaster cotteaui Egozcue, found at this locality indicates Antiguan Oligocene.

\section{TERTIARY ECHINOIDS FROM PORTO RICO.}

The discussion of the Porto Rican echinoids will be introduced by quoting Dr. Carlotta J. Maury's table of geological formations in Porto Rico. ${ }^{1}$ Dr. Maury correlated the middle Oligocene of her table with the Antigua formation and the upper Oligocene of her table with the Anguilla formation.

Table of Tertiary formations in Porto Rico (after C. J. Maury).

\begin{tabular}{|c|c|c|c|c|}
\hline & & & North Side. & South Side. \\
\hline 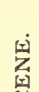 & 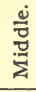 & \multirow{4}{*}{ 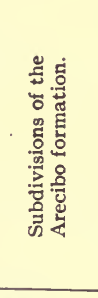 } & $\begin{array}{l}\text { Quebradillas limestone with Bow- } \\
\text { den fauna and Metis trinitaria. }\end{array}$ & \\
\hline$\underset{2}{0}$ & $\begin{array}{l}\dot{0} \\
\stackrel{\Delta}{0}\end{array}$ & & & \\
\hline \multirow{3}{*}{$\begin{array}{l}\text { 国 } \\
z \\
\text { : } \\
0 \\
0 \\
0 \\
0 \\
0\end{array}$} & $\dot{\Phi}$ & & $\begin{array}{l}\text { Aguadilla limestone with Orthau- } \\
\text { lax aguadillensis. }\end{array}$ & \multirow[t]{2}{*}{$\begin{array}{l}\text { Ponce chalky beds with Ostrea } \\
\text { cahobasensis. }\end{array}$} \\
\hline & 5 & & $\begin{array}{l}\text { Lares limestone with Campanile } \\
\text { (Portoricia) laricum. }\end{array}$ & \\
\hline & : & 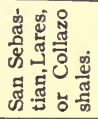 & $\begin{array}{l}\text { Rio Collazo shales with Clemen- } \\
\text { tia rabelli. }\end{array}$ & $\begin{array}{c}\text { Guanica shaly limestone with } \\
\text { Ostrea antiguensis. }\end{array}$ \\
\hline
\end{tabular}

On the following page is a table of the Tertiary echinoids from Porto Rico described by Doctor Jackson in his paper.

First, with regard to the "Arecibo" formation of Berkey, according to Berkey's original description of the formation, ${ }^{2}$ it seems to me that he intended the name to apply to all deposits between the Cretaceous and Pleistocene in Porto Rico, and that he included in it the San Sebastian, Lares, and Collazo shales.

According to the information supplied Doctor Jackson on horizons whence the echinoids came, the base of the "Arecibo" formation, the Collazo shale, and the San Sebastian shale represent one horizon. This horizon has Echinolampas lycopersicus in common with the

\footnotetext{
${ }^{1}$ Maury, C. J., Tertiary Mollusca from Porto Rico: New York Acad. Sci. Scientific Survey of Porto Rico and the Virgin Islands, vol. 3, part 1, table opposite p. 4, 1920.

2 Berkey, Charles P., Geological Reconnaissance of Porto Rico, New York Acad. Sci. Ann.. vol. 26, pp. $12-17,1915$.
} 
Antiguan and Anguillan horizons. The Guanica shaly limestone and the Juana Diaz have Clypeaster oxybaphon in common with the Antigua formation of Antigua, where I collected specimens. It therefore appears that the deposits bearing five names in Porto Rico, viz, San Sebastian, Lares, Collazo, and Juana Diaz shale, and Guanica shaly limestone, represent essentially the same horizon, and it is, as Doctor Maury indicates in her table, the Antiguan horizon. The evidence of the echinoids on this problem is interesting in that it accords with the conclusions based on studies of both the corals ${ }^{1}$ and the mollusks.

Tertiary Echinoids from Porto Rico.

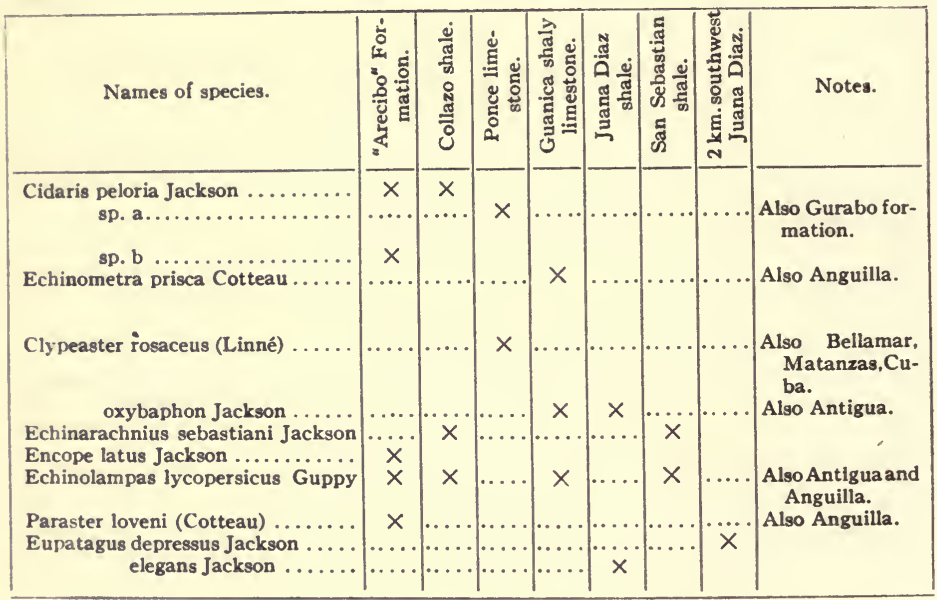

There are no echinoids definitely referred to the Lares, Aguadilla, and Quebradillas limestones. The two species recorded from the Ponce limestone indicate that it is of Miocene, not Oligocene, age. Recent work in Haiti has shown according to Dr. W. P. Woodring (oral statement) that Ostrea cahobasensis is Miocene, not Oligocene, as indicated in Doctor Maury's table quoted above.

${ }^{1}$ For an account of some corals from the same horizon and an earlier similar correlation, see T. W. Vaughan, U. S. Nat. Mus. Bull. 103, pp. 203, 204, 1919. I first made this correlation in 1899. I wish here to call attention to a misrepresentation of my usage of terms in my discussions of Porto Rican horizons. Bela Hubbard in his "Tertiary Mollusca from the Lares district, Porto Rico," N. Y. Acad. Sci. Scientific Survey of Porto Rico, et cetera, vol. 3, pt. 2, pp. 79-164, 1920 , in the table on p. 79 , represents me as having classified under the Pepino formation everything from middle Oligocene to his "upper Oligocene," which is probably late Miocene. A very casual reading of my use of the term "Pepino" would have shown Doctor Hubbard that I confined the use of the name to a single horizon, palæontologically characterized by the fossil corals I have listed in U. S. Nat. Mus. Bull. 103, p. 204. The horizon is considered middle Oligocene. Hill may have intended the term to have a more extensive application. but of this I am not sure. 


\section{TERTIARY ECHINOIDS FROMßBARBADOS.}

Two species of Tertiary echinoids are known from the Bissex Hill formation of Barbados, viz, Eupatagus abruptus (Gregory) and Echinolampas anguilla Cotteau. ${ }^{1}$ Because of the presence of Echinolampas anguille in it, the Bissex Hill formation may be confidently referred to the Oligocene, but whether middle or upper can not be decided from present evidence. A note on another species of Eupatagas from Barbados appears on page 3 .

\section{MIOCENE.}

List of species from the West Indies Miocene.

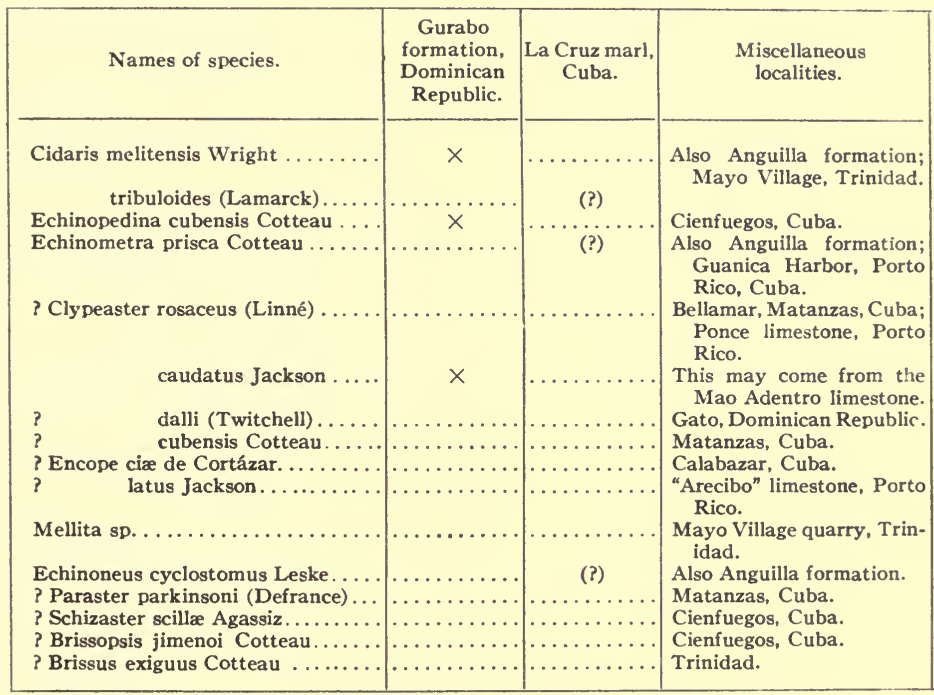

Examination of this list reveals that only four species of echinoids are definitely known from the West Indian Miocene. These are:

Cidaris melitensis Wright, Mayo Village, Trinidad.

Echinopedina cubensis Cotteau, Gurabo formation, Dominican Republic.

Clypeaster caudatus Jackson, Gurabo formation or Mao Adentro limestone, Dominican Republic.

Mellita sp., Mayo Village, Trinidad.

1 R. J. L. Guppy, on the geology of Antigua and other West Indian Islands, with references to the physical history of the Caribbean region: Geol. Soc. London Quart. Jour., vol. 67, p. 692, 1911. I am indebted to Sir J. B. Harrison for this reference to Echinolampas anguilla, which had escaped my notice. 
All other species on the list may be of Miocene age, but additional information is needed before a definite opinion is warranted.

The few species of Miocene echinoids known from the West Indies is rather surprising, because the number of species of Miocene organisms is probably as much as ten times more than all of those from the Eocene and Oligocene formations combined. The sediments of the different epochs are different. The Eocene and Oligocene deposits are largely calcareous and contain organisms of reef facies, viz, corals, calcareous algæ, large Foraminifera such as Orthophragmina, Lepidocyclina, and Operculina, incrusting Bryozoa, and echinoids. The Miocene strata as a rule are less calcareous and more arenaceous or argillaceous, and are exceedingly rich in species of mollusca, the number of species of this group probably exceeding 2,000; there are many species of smaller Foraminifera and Bryozoa, and simple corals are abundant. But in some places there are calcareous Miocene strata, and when they are searched for echinoids they may yield additions to the Miocene echinoid faunas.

These quantitative relations of the echinoids to the mollusks hold true also in the United States. Echinoids are most abundant in the Ocala limestone, of upper Eocene age, approximately contemporaneous with the St. Bartholomew limestone; there are a few common species in the Oligocene (Vicksburg group and Chattahoochee formation); but they are very rare in the Miocene, in striking contrast to the great profusion of mollusks in the Alum Bluff and Choctawhatchee formations.

The following are the names of the known Miocene echinoids from Panama and Costa Rica:

Clypeaster gatuni Jackson.1 Miocene, Gatun formation, station 5662, near Gatun Dam site; and upper Oligocene, Emperador limestone at station 6237, north of Ancon Hill, about 4 miles south of Diablo ridge.

Encope annectans Jackson.1 Miocene, Gatun formation, station 5846, Spillway, Gatun Dam.

Encope platytata Jackson.1 Miocene, Gatun formation, station $6029 a, 0.25$ to 0.5 mile from Camp Cotton, toward Monte Lirio.

Encope megatrema Jackson. ${ }^{1}$ Miocene, Gatun formation, station 6030, about 1.5 miles from Camp Cotton, toward Monte Lirio.

Encope gatunensis Toula. ${ }^{2}$ Miocene, Gatun formation.

Schizaster armiger W. B. Clark. ${ }^{1}$ Miocene (?), Bonilla, Costa Rica.

Schizaster cristatus Jackson. ${ }^{2}$ Miocene (?), Brazil, Costa Rica, station 5505.

Schizaster panamensis Jackson.1 Miocene, Gatun formation, near Gatun, stations 6008 and 7294 .

\footnotetext{
I Jackson, R. T., Fossil Echini of the Panama Canal Zone and Costa Rica: U. S. Nat. Mus. Bull. 103, pp. 103-116, I, pls. 46-52, 1918.

Toula, Franz, Die jung-tertiăre Fauna von Gatun am Panama Kanal: Geolog. ReichsAnstalt, Wien, vol. 61, pp. 487-530, pls. 30-31, 1911.
} 
Table of West Indian Echinoids of stratigraphic value.

\begin{tabular}{|c|c|c|c|c|c|}
\hline \multirow{2}{*}{ Species. } & \multirow{2}{*}{$\begin{array}{l}\text { Creta- } \\
\text { ceous. }\end{array}$} & \multirow{2}{*}{ Eocene. } & \multicolumn{2}{|c|}{ Oligocene. } & \multirow{2}{*}{$\begin{array}{l}\text { Mio- } \\
\text { cene. }\end{array}$} \\
\hline & & & Middle. & Upper. & \\
\hline Codiopsis arnaudi Cotteau .. & $x$ & & & & \\
\hline Salenia scutigera (Münster).... & $\times$ & & $\cdots$ & & \\
\hline Phymosoma cubense (Egozcue). & $x$ & & & & \\
\hline Conulus antillensis (Cotteau) . . & $x$ & & $\ldots$ & & $\ldots$ \\
\hline Lanieria lanieri (Cotteau)... & $x$ & & & & \\
\hline Discoidea decorata Desor.... & $\times$ & & $\ldots$ & & $\ldots$ \\
\hline Cardiaster cubensis Jackson & $\times$ & & & & ...... \\
\hline Hemiaster berkeyi Jackson. & $x$ & & $\ldots$. & & $\ldots \ldots$ \\
\hline Cidaris loveni Cotteau ..... & $\cdots \cdots$ & $\times$ & $\ldots$. & & ...... \\
\hline Sismondia antillarum Cotteau & ..... & $x$ & $\ldots \ldots$ & & $\cdots \cdots$ \\
\hline Peronella mirabilis Jackson ..... & & $x$ & $\ldots$. & & $\cdots \cdots$ \\
\hline Parapygus antillarum (Cotteau)... & $\ldots .$. & $\times$ & $\ldots$. & . & ...... \\
\hline Echinolampas antillarum Cotteau . .......... & & 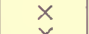 & $\cdots$ & & $\cdots \cdots$ \\
\hline $\begin{array}{l}\text { ovumserpentis Guppy.......... } \\
\text { clevei Cotteau }\end{array}$ & & $\frac{x}{x}$ & $\cdots \cdots$ & & $\cdots \cdots$ \\
\hline $\begin{array}{r}\text { clevei Cotteau } \\
\text { Asterostoma cubense Cotteau. } \ldots \ldots \ldots \ldots \ldots \ldots \ldots\end{array}$ & $\cdots$ & $\begin{array}{l}x \\
x\end{array}$ & $\ldots \cdots$ & & $\cdots \cdots$ \\
\hline Pseudasterostoma jimenoi (Cotteau) ........... & $\cdots$ & $\widehat{x}$ & $\cdots \cdots$ & & $\cdots \cdots$ \\
\hline Agassizia inflata Jackson.$\ldots \ldots \ldots \ldots \ldots$ & $\ldots$ & $x$ & $\ldots \ldots$ & & $\ldots \ldots$ \\
\hline Prenaster loveni Cotteau ............... & $\ldots$ & $x$ & $\ldots$ & & $\cdots \cdots$ \\
\hline Paraster antillarum (Cotteau) ... & .... & $\times$ & $\ldots \ldots$ & & $\cdots \cdots$ \\
\hline & $\ldots$. & $\times$ & $\ldots \ldots$ & & ….. \\
\hline Periaster elongatus Cotteau ... & $\ldots$ & $\times$ & . & & $\cdots \cdots$ \\
\hline Plagiobrissus loveni (Cotteau) .......... & $\cdots$ & $\times$ & $\ldots$ & & … \\
\hline Macropneustes antillarum (Cotteau)........ & … & $x$ & . & & $\ldots \ldots$ \\
\hline Eupatagus grandiflorus (Cotteau) ......... & ..... & $x$ & $\ldots \ldots$ & & $\cdots \cdots$ \\
\hline clevei (Cottea & & $\times$ & & & $\cdots \cdots$ \\
\hline$($ Cotteau $) . \ldots \ldots \ldots$ & ... & $\underset{x}{x}$ & & & …... \\
\hline cubensis (Cotteau).... & $\cdots$ & $\times$ & $x$ & & $\cdots \cdots$ \\
\hline Cidaris peloria Jackson......... & ‥ & $\ldots \ldots$ & $\underset{x}{x}$ & $\dddot{x}$ & … \\
\hline Sismondia anguillæ Cotteau ... & .. & $\ldots \ldots$ & $\begin{array}{l}x \\
x\end{array}$ & $\underset{x}{x}$ & $\cdots \cdots$ \\
\hline Clypeaster concavus Cotteau... & & … & $x$ & $x$ & …… \\
\hline lance & .... & $\ldots \ldots$ & $\times$ & $\times$ & $\cdots \cdots$ \\
\hline antillar & ... & $\ldots$. & $x$ & $\times$ & $\ldots \ldots$ \\
\hline planipetalus Cot & & $\ldots \ldots$ & $x$ & & $\cdots \cdots$ \\
\hline cryptc & & $\ldots$. & $x$ & & …. \\
\hline cotte & & $\ldots$. & $x$ & ? & $\cdots \cdots$ \\
\hline batheri Lambe & & .... & $x$ & & $\cdots \cdots$ \\
\hline parvu & & & $x$ & ? & $\cdots \cdots$ \\
\hline & & ..... & $\times$ & & …. \\
\hline Echinarachnius sebastiani Jackson........... & & & $x$ & & $\ldots \ldots$ \\
\hline Echinolampas lycopersicus Guppy ........... & .... & $\ldots$. & $\times$ & $x$ & $\cdots \cdots$ \\
\hline & & & $x$ & $x$ & ........ \\
\hline Paraster clevei (Cotteau) $\ldots \ldots \ldots \ldots \ldots \ldots$. & & & $\times$ & $x$ & ….. \\
\hline Eupatagus vaughani Jackson.... & & & $x$ & & $\ldots \ldots$ \\
\hline & & & $\times$ & & \\
\hline Cidaris anguillæ Cotteau $\ldots \ldots \ldots \ldots \ldots \ldots$ & & & $\ldots$. & $x$ & \\
\hline clevei Cotteau... & & & & $x^{x}$ & \\
\hline melitensis Wright $\ldots \ldots \ldots \ldots \ldots \ldots$ & & & $\cdots \cdots$ & $x$ & $\times$ \\
\hline Echinometra prisca Cotteau . . . . . . . . . . & & & & $x$ & ? \\
\hline Echinoneus cyclostomus Leske $\ldots \ldots \ldots \ldots \ldots$ & & & & $x$ & ? \\
\hline Echinolampas semiorbis Guppy . . . . . . . . . & & $\ldots$. & & $x$ & ..... \\
\hline Agassizia clevei Cotteau............... & & $\cdots$ & & $x$ & $\cdots \cdots$ \\
\hline Paraster lovenl (Cotteau)....... & & & & $x$ & ….. \\
\hline Macropneustes clevei (Cotteau). & & & & $x$ & ...... \\
\hline Brissopsis antillarum Cotteau ... & & & & $x$ & \\
\hline Brissus exiguus Cotteau ......... & & & & $x$ & $\stackrel{?}{\text { ? }}$ \\
\hline Cidaris tribuloides (Lamarck) . . . . . . . . . . . & & & & & $\underset{x}{x}$ \\
\hline Echinopedina cubensis Cotteau............. & & & & & 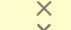 \\
\hline Clypeaster caudatus Jackson . . . . & & & & & $\times$ \\
\hline
\end{tabular}




\section{POST-MIOCENE ECHINOIDS.}

The following table gives the West Indian species of echinoids that are of Pliocene or younger age and of unknown geologic age younger than Miocene:

List of West Indian post-Miocene Fossil Echinoids.

\begin{tabular}{|c|c|}
\hline Horizon and names. & Localities, etc. \\
\hline 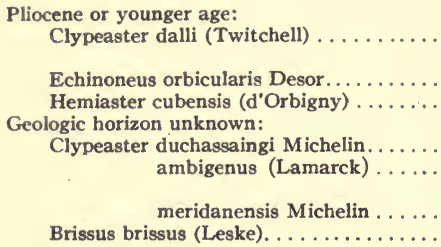 & $\begin{array}{l}\text { Gato, Dominican Republic. (Also Caloosa- } \\
\text { hatchee marl.) } \\
\text { Cuba (Recent). } \\
\text { Cuba (Pliocene or Recent). } \\
\text { Guadeloupe ("Formation madréporique"). } \\
\text { Guadeloupe ("Formations moderne et ma- } \\
\text { dréporique"). } \\
\text { Yucatan and Guadeloupe (probably Pliocene). } \\
\text { Cuba and Guadeloupe (Pliocene). }\end{array}$ \\
\hline
\end{tabular}

SPECIES OF ESTABLISHED STRATIGRAPHIC VALUE.

From preceding tables and discussion, the table of species (page 121) of ascertained stratigraphic value has been constructed.

Eupatagus abruptus (Gregory) from the Bissex Hill formation of Barbados is an Oligocene species, but whether it comes from the Antiguan or Anguillan horizon is not known. 



Physical Sciences Library

DATE DUE

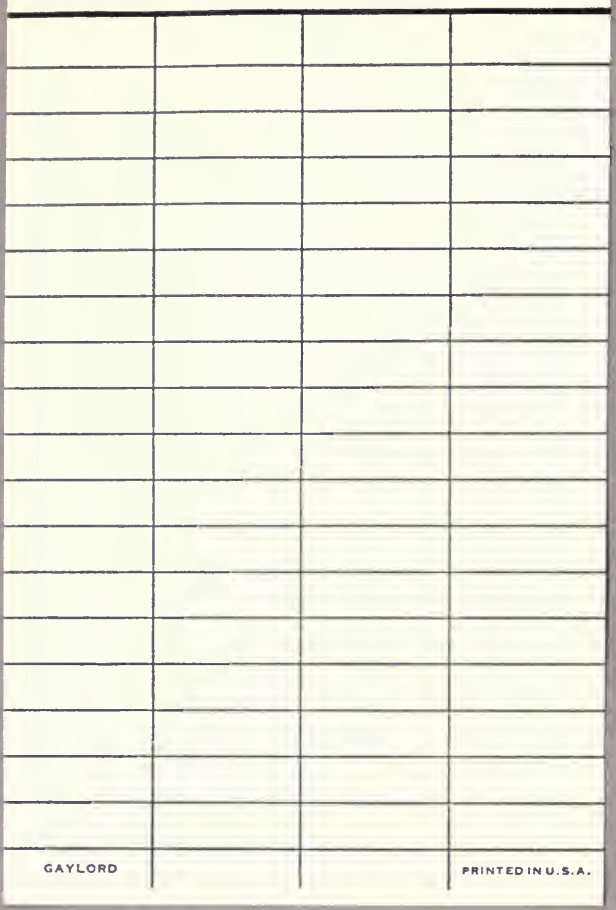


Phys.Sci.

QE783 Jackson, Robert T. 12J 8

1922 Fossil Echini of the west Indies.

Phys.Sci.

¿.783 Jackson, "obert T.

Е2ง

1922 Fossil Echini of the West Indies.

Physical Salinces Library

University of California

Riverside 
.

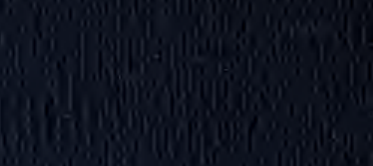

148 .

P.

Pontion

(1)

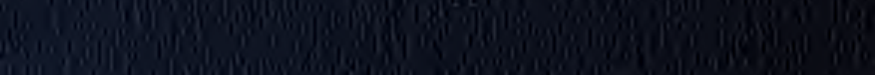

(1il ,

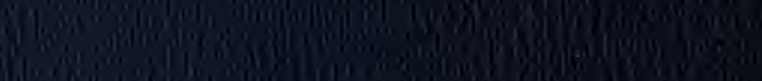

I.

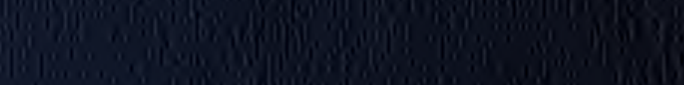

Ution

9.

1

,

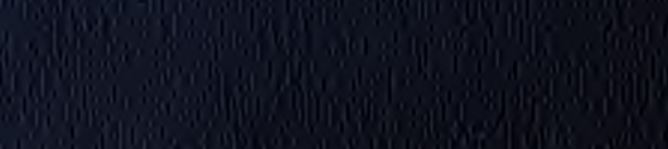

I,

(1)

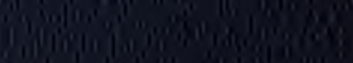

